UNIVERSIDADE DE SÃO PAULO

FACULDADE DE FILOSOFIA, LETRAS E CIÊNCIAS HUMANAS

DEPARTAMENTO DE HISTÓRIA

PROGRAMA DE PÓS-GRADUAÇÃO EM HISTÓRIA SOCIAL

MARCOS CORRÊA DE MELLO FELISETTE

A linguagem gráfica de Aloisio Magalhães

e o projeto editorial no Brasil (os anos 50 e 60) 
MARCOS CORRÊA DE MELLO FELISETTE

\section{A linguagem gráfica de Aloisio Magalhães e o projeto editorial no Brasil (os anos 50 e 60)}

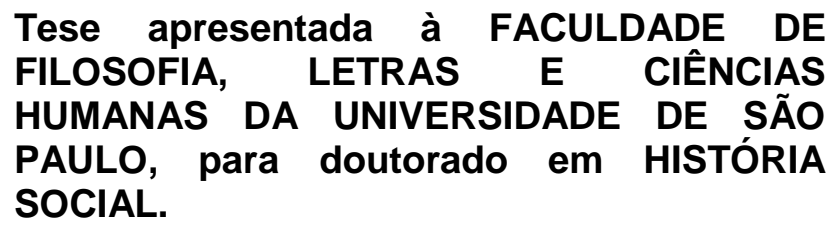

Orientador: Prof. Dr. Arnaldo Daraya Contier

De acordo: 
À minha família, em especial aos meus pais, Maria Alice e Salvador, por, desde a infância, terem me incentivado aos estudos em arte, o que mais tarde viria a se concretizar na minha profissão de tipógrafo.

Aos meus filhos João, Pedro e, hoje, Clarissa e Lorena.

À minha esposa, Patrícia, companheira de todos os momentos, com profundo amor e carinho. 


\section{AGRADECIMENTOS}

- Prof. Dr. Arnaldo Daraya Contier, a quem sinceramente chamo de Mestre. Meu interesse pela História da Cultura se deve à sua imensa sabedoria e contagiosa diversidade de conhecimentos nesse campo de pesquisa. Sua orientação foi fundamental para a realização deste trabalho.

๙ Prof. Dr. Guilherme Cunha Lima, que me acolheu e que, além de me apresentar importantes fontes primárias, me presenteou com sua amizade e conversas preciosas sobre o objeto desta pesquisa.

ฯ Profa. Dra. Edna Lucia Cunha Lima, não só por suas contribuições, mas, especialmente, pela amizade e atenção que auxiliaram imensamente no amadurecimento desta pesquisa.

$\infty$ Prof. Dr. Elias Thomé Saliba e Prof. Dr. Francisco Homem de Melo, pelas observações e intervenções absolutamente necessárias feitas na qualificação.

- Joaquim Redig, pela disponibilidade em me receber e compartilhar de sua experiência com Aloisio Magalhães.

- Profa. Dra. Ana Mae Barbosa pelas valiosas conversas e questões discutidas sobre Aloisio Magalhães.

s João de Souza Leite, pela atenção em disponibilizar a sua tese, de grande valia para esta pesquisa.

- Claudio Rocha, Claudio Ferlauto, Norberto Gaudêncio Jr., amigos que contribuíram, não somente com importante material de pesquisa, mas, principalmente, pelo incentivo e reconhecimento do meu trabalho.

- Prof. Manoel Manteigas, diretor da Escola Senai Theobaldo De Nigris, que acredita e valoriza a arte tipográfica.

ฯ Aos mestres tipógrafos pelo constante ensinamento do ofício, representados pelos senhores Pérsio e Luís [in memorian].

- Figueiredo "Paraná", linotipista, pela sua experiência e dados históricos compartilhados.

\$ Luiz Carlos Soggia, Marcelo Sartori, Alexandre Maltez, Gerson Alves de Almeida, Idelfonso Elias, profissionais da Escola Senai Theobaldo De Nigris, pelo auxílio na investigação técnica dos processos de impressão gráfica.

- Silvio Barreto Campello, Isabella Aragão e Leonardo A. Costa Buggy pela acolhida em Recife e abertura dos ateliês tipográficos e acervo da Universidade Federal de Pernambuco.

- E todos os amigos que, por meio de suas palavras de carinho e apoio, contribuíram para a conclusão deste trabalho. 


\section{RESUMO}

A presente pesquisa investiga a linguagem gráfica de Aloisio Magalhães, artista gráfico, que entre os anos de 1950 e 1960 participou do grupo "O Gráfico Amador", cuja produção no campo editorial pontua a história da moderna tipografia no Brasil. Nesse período, Aloisio Magalhães intensificou suas experiências no campo das artes gráficas, realizando um trabalho coletivo na criação de livros com a utilização de técnicas variadas em sua linguagem, característica da produção d'O Gráfico Amador enquanto produção experimental na área.

Durante sua vivência junto ao grupo, viajou para os Estados Unidos, em 1956, onde conheceu o artista gráfico Eugene Feldman, com quem iniciou uma série de experiências no campo gráfico a partir das novas tecnologias de impressão. Como fruto dessa vivência, estabeleceu novo entendimento e curso à sua prática artística, contribuindo de forma decisiva para o início da construção da atividade profissional de design gráfico no Brasil.

Para compreender a amplitude dessas questões, a pesquisa contempla o aprofundamento do estudo da tipografia, da história do livro e o papel do editor, do tipógrafo e do artista gráfico como vetores na delineação e construção da história do projeto editorial no Brasil, história na qual Aloisio Magalhães tem relevante participação.

A partir desse referencial teórico e análise comparativa da linguagem formulada por Aloisio Magalhães, a pesquisa investiga as particularidades de sua atuação enquanto artista gráfico frente à produção editorial em nosso país, entre as décadas de 1950 e 1960, e aponta os caminhos de como sua linguagem se modificou e se estabeleceu a partir de então.

Palavras chave: Linguagem gráfica, Tipografia, Projeto editorial, Design Gráfico, História do livro no Brasil. 


\section{RÉSUMÉ}

La présente recherche porte sur le langage graphique d'Aloisio Magalhães, artiste graphique, qui entre les années 1950 e 1960 a participé au groupe "O Gráfico Amador", dont la production dans le domaine éditorial, occupe une place importante dans l'histoire de la typographie moderne au Brésil. Au cours de cette période, Aloisio Magalhães intensifie ses expériences dans le cadre des arts graphiques, et réalise un travail collectif dans la création de livres utilisant dans son langage des techniques variées, caractéristique de la production du O Gráfico Amador en sa qualité de production expérimentale dans ce domaine.

Durant cette période de contact avec le groupe, il part aux Etats-Unis, en 1956, où il connaît l'artiste graphique Eugene Feldman, avec qui il se consacre à une série d'expériences dans le cadre graphique à partir des nouvelles technologies d'impression. Grâce à ce vécu, il met en lumière une nouvelle entente et donne un nouveau cours à sa pratique artistique, contribuant de manière décisive au début de la construction de l'activité professionnelle de design graphique au Brésil.

Pour comprendre l'amplitude de ces questions, la recherche a pour objet l'approfondissement de l'étude de la typographie, de l'histoire du livre et le rôle de l'éditeur, du typographe et de l'artiste graphique comme vecteurs de la structuration et la construction de l'histoire du projet éditorial au Brésil, histoire à laquelle Aloisio Magalhães a une participation essentielle.

À partir de ce cadre théorique et de l'analyse comparatif du langage formulé par Aloisio Magalhães, la recherche vise à connaître les particularités de son activité en tant qu'artiste graphique vis-à-vis de la production éditoriale dans notre pays, entre les décennies 1950 et 1960, et montre les manières dont son langage se modifie et se consolide dès lors.

Mots-clés: Langage graphique, Typographie, Projet éditorial, Design Graphique, Histoire du livre au Brésil. 


\section{LISTA DE ILUSTRAÇÕES}

llustr. (1) Eugene Feldman e Aloisio Magalhães no lançamento do livro Doorway to Brasilia, com Juscelino Kubitschek .48

Ilustr. (2) Aloisio Magalhães e Eugene Feldman ................................................48

Ilustr. (3) Aloisio Magalhães e Eugene Feldman ................................................53

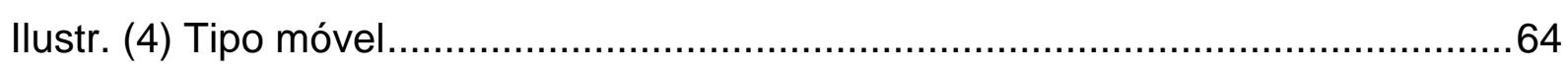

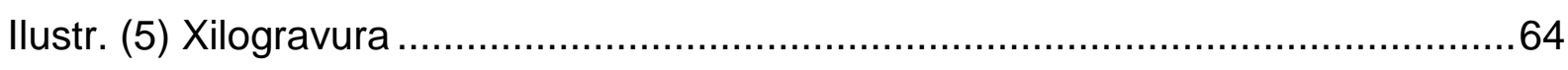

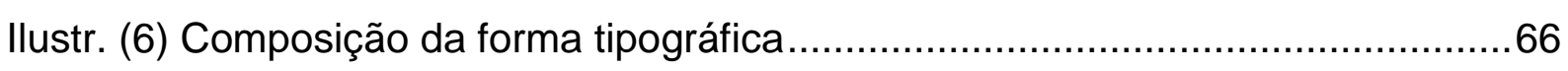

Ilustr. (7) Composição da forma tipográfica.......................................................67

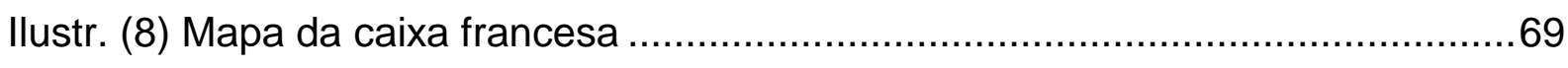

llustr. (9) Régua tipográfica .......................................................................

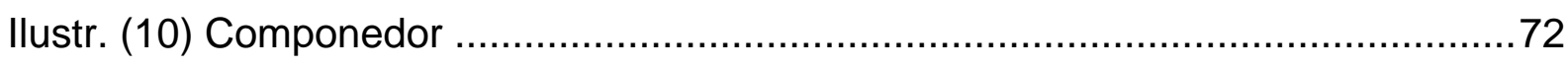

llustr. (11) Composição ........................................................................... 72

Ilustr. (12) Pinça tipográfica......................................................................... 73

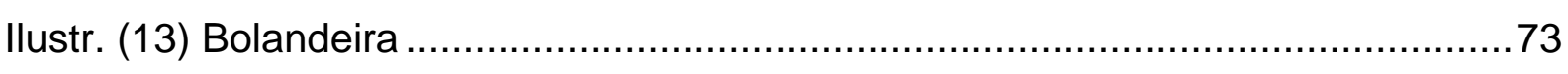

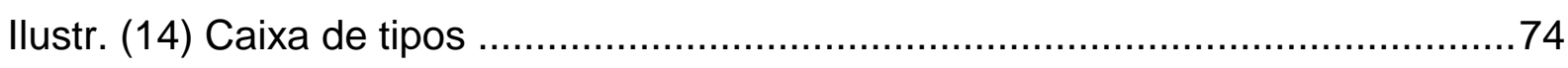

Ilustr. (15) Gaveteiro de tipos - cavalete ………...........................................

llustr. (16) Caixa de espaços.........................................................................

Ilustr. (17) Quadro esquemático da caixa de espaços ...........................................77

llustr. (18) Tabela de espaços - quadratins .......................................................78

Ilustr. (19) Tabela de entrelinhas..................................................................

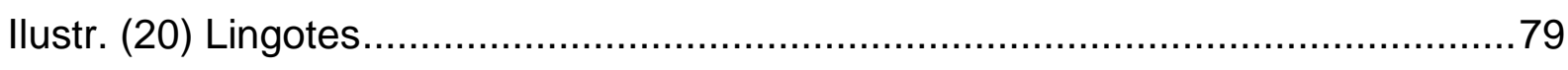

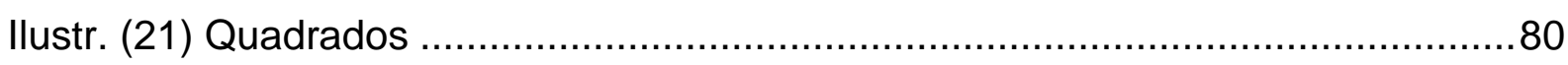

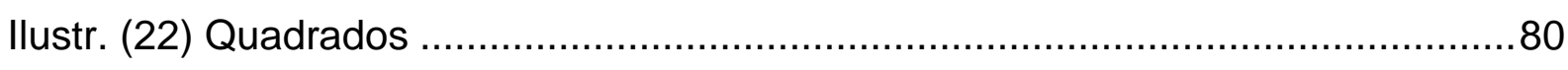

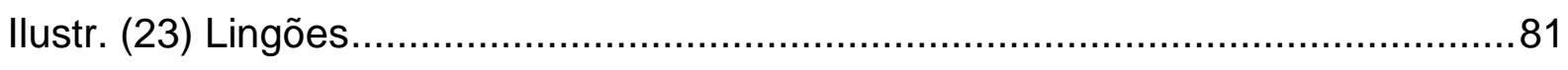

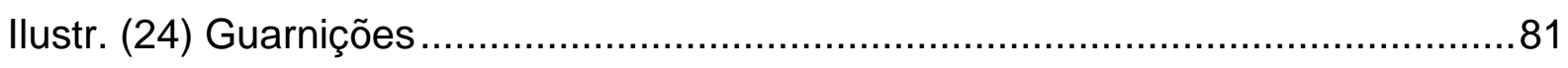

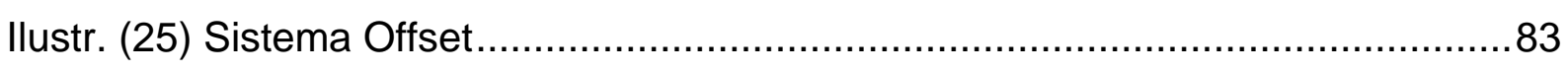

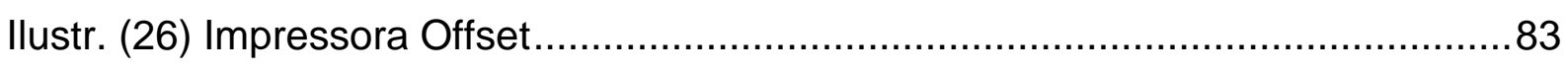

Ilustr. (27) Variação de matrizes de um mesmo caractere - Bíblia de 42 linhas,

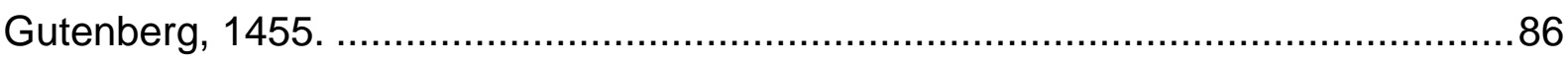

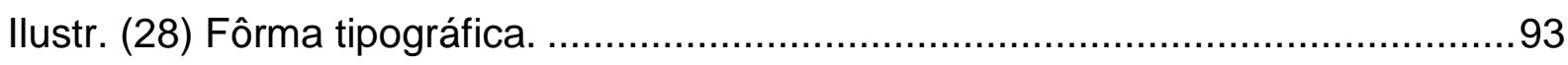

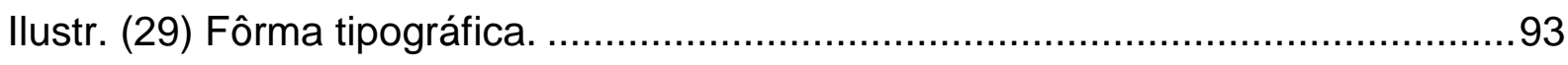




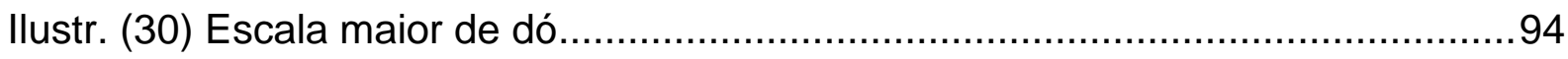

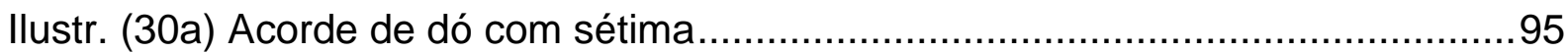

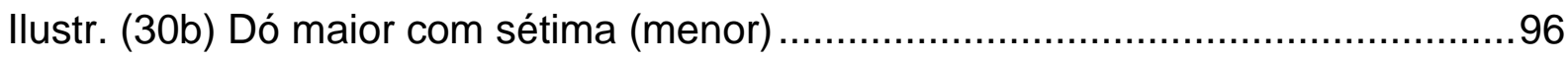

llustr. (31) Linhas compostas na fôrma tipográfica................................................99

Ilustr. (32) Quadros análogos - comparativo entre notação musical e elementos da

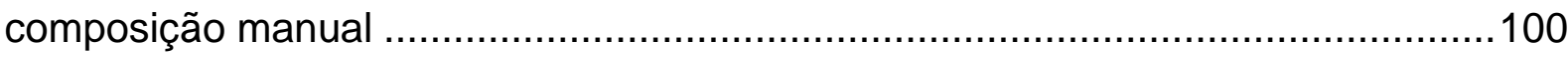

Ilustr. (33) Exemplo de composição de um chorus..............................................101

llustr. (34) Punção e contra-punção ...........................................................107

Ilustr. (35) Punção e matriz da letra $\mathrm{H}$ - Imagem de Theodore Low De Vinne - The

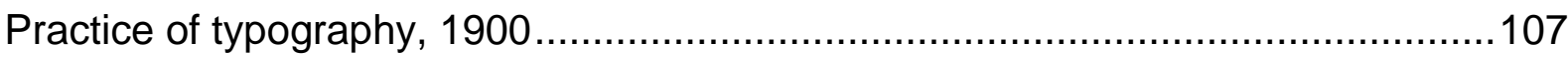

Ilustr. (36) Punções do tipo Tallone - Charles Malin, 1955 ..................................108 Ilustr. (37) Punções de Claude Garamond em exposição no Museu Platin Moretus -

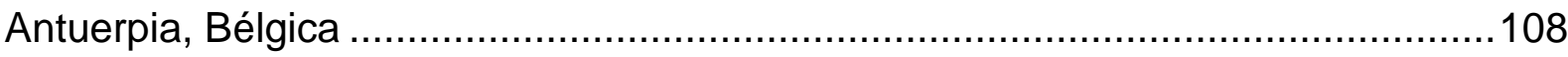

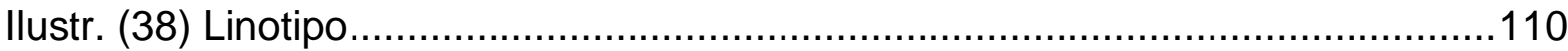

Ilustr. (39) Sr. Figueiredo, popularmente conhecido como "Paraná" Linotipista da Oficina Tipográfica São Paulo .....................................................................114

Ilustr. (40) Capa de Santa Rosa para Lampião, 1952 .......................................126

llustr. (41) Capa de Santa Rosa para Cangaceiros, $1955 \ldots \ldots \ldots \ldots \ldots \ldots \ldots \ldots \ldots \ldots \ldots \ldots . . . . .126$

llustr. (42) Capa de Santa Rosa para José Olympio, na década de 1940...............126

Ilustr. (43) Capa de Santa Rosa, 1953 .........................................................126

Ilustr. (44) Página dupla ilustrada do livro Hypnerotomachia Poliphili, de Francesco

Colonna, Venenza, 1499, in-fólio, 202 × 312 mm............................................132

Ilustr. (45) Página dupla ilustrada do livro Hypnerotomachia Poliphili, de Francesco

Colonna, Venenza, 1499, in-fólio, 202 x 312 mm...........................................133

llustr. (46) O circuito das comunicações ........................................................135

llustr. (47) Capa do "Livro do Bibliófilo" ............................................................138

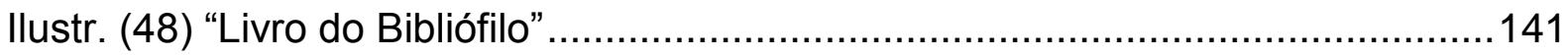

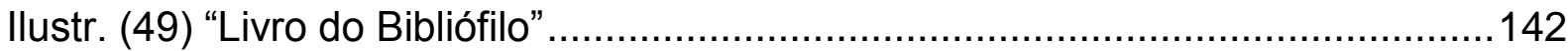

Ilustr. (50) La Scuola Tipografia Moderna .......................................................145

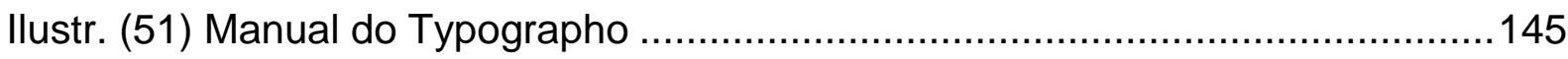

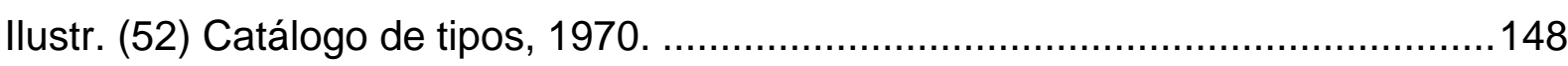

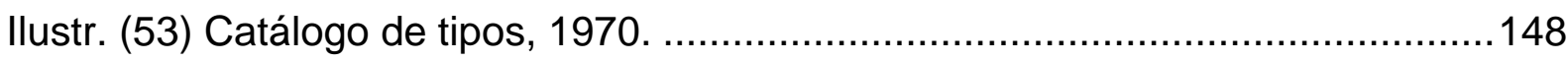

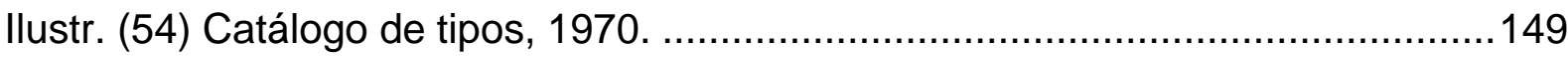

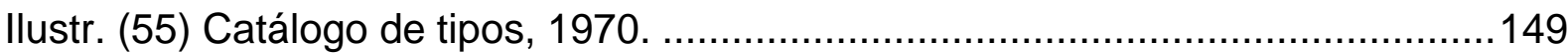


llustr. (56) Compositor com caixa de tipos, componedor e galé - Gravura de Taubel, 1810 150

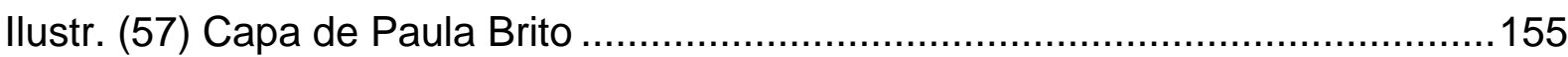

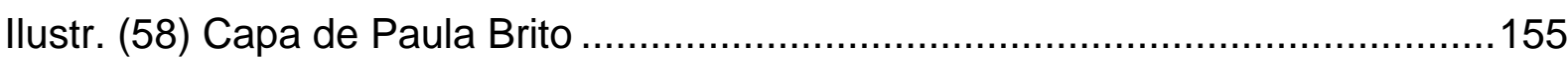

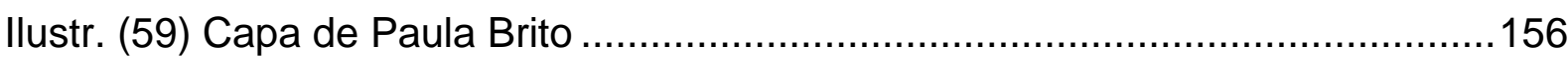

Ilustr. (60) Capa de Fernando Corona - Um dos primeiros livros editados pela Livraria

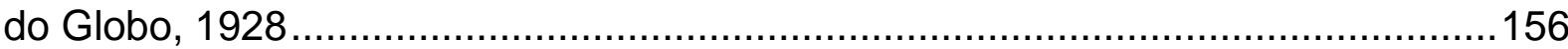

Ilustr. (61) Capa de Fernando Correia Dias para a Editora Leite Ribeiro, 1918. .....156 Ilustr. (62) Aloisio (de chapéu), José Laurenio de Melo, Orlando Ferreira (lendo) e Abel Accioly (sentado no peitoril da janela), no atelier no sótão da Rua Amélia. ....159 Ilustr. (63) Primeira impressora tipográfica d'O Gráfico Amador .............................161 Ilustr. (64) Segunda impressora tipográfica d'O Gráfico Amador ..........................161 Ilustr. (65) Impressora litográfica Karl Krause Leipzig, o 17133 d’O Gráfico Amador 162

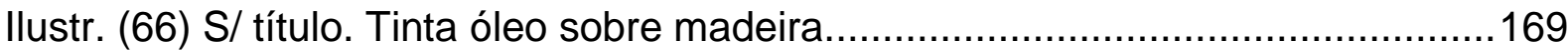

Ilustr. (67) S/ título. Aquarela sobre papel. ..........................................................169

Ilustr. (68) S/ título. Tinta óleo sobre madeira...................................................170

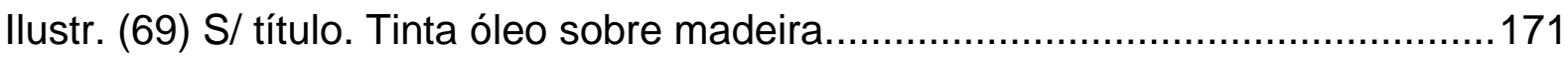

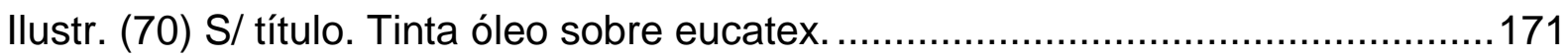

Ilustr. (71) S/ título. Tinta tipográfica sobre eucatex ………………………....... 172

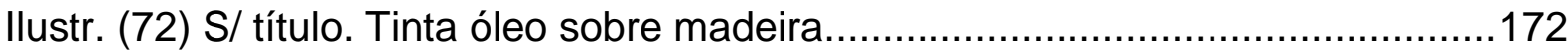

Ilustr. (73) S/ título. Tinta tipográfica sobre papel...............................................173

Ilustr. (74) S/ título. Tinta tipográfica sobre tecido. ..............................................173

Ilustr. (75) Da esquerda para a direita, de pé: lara Lins, Jorge Wanderley, Ruth, Adão Pinheiro, Adauto, o casal Flávio Damm e Montez Magno. Sentados estão Aloisio, Aldomar Conrado e Sebastião Uchoa Leite. .........................................................174 Ilustr. (76) S/título. Monotipia sobre papel............................................................176 Ilustr. (77) S/título. Monotipia sobre papel, 1957 .............................................176 Ilustr. (78) Aniki Bobó. O Gráfico Amador, Recife, 1958.....................................179 Ilustr. (79) Memórias do Boi Serapião - O Gráfico Amador, Recife, 1955..............181 Ilustr. (80) Pregão Turístico do Recife - O Gráfico Amador, Recife, 1955...............182 Ilustr. (81) Improvisação Gráfica - O Gráfico Amador, Recife, 1958. .....................184 Ilustr. (82) Símbolo d'O Gráfico Amador ...........................................................185 Ilustr. (83) The Next Call 4............................................................................ 188 


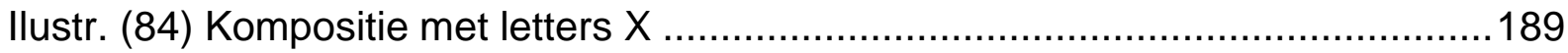

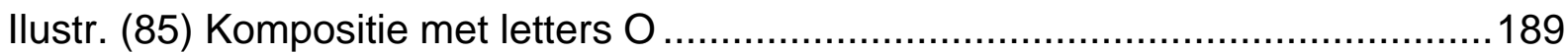

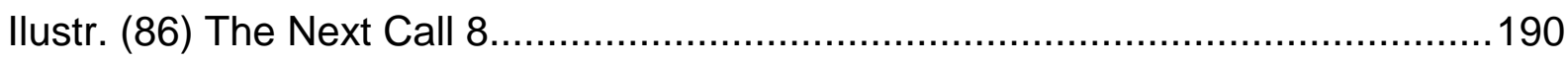

llustr. (87) Aloisio Magalhães e Eugene Feldman na The Falcon Press .................194

Ilustr. (88) Aloisio Magalhães e Eugene Feldman na The Falcon Press .................195

Ilustr. (89) Detalhe do bailarino russo Rudolf Nureyev - Impressão de Eugene

Feldman ...

Ilustr. (90) Quatro exemplares de uma série sobre Veneza - Impressão de Eugene

Feldman

llustr. (91) Pregão Turístico do Recife. João Cabral de Melo Neto. O Gráfico Amador, Recife, 1955. 202 llustr. (92) Memórias do Boi Serapião. Carlos Pena Filho - O Gráfico Amador, Recife, 1955 202

Ilustr. (93) Página G do livro Doorway to Portuguese, 1957 ..................................203

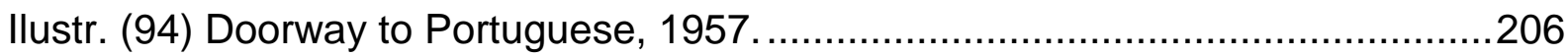

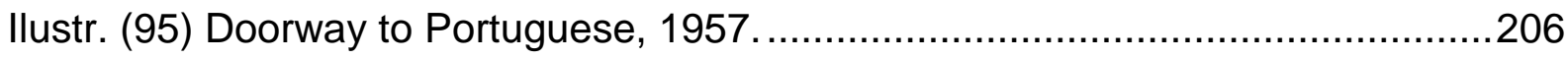

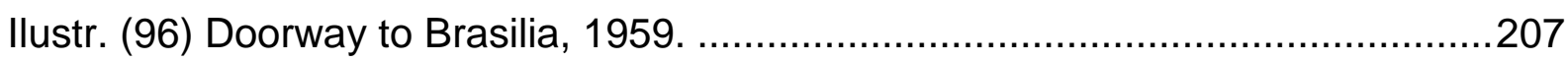

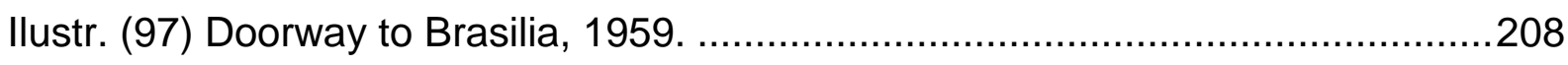

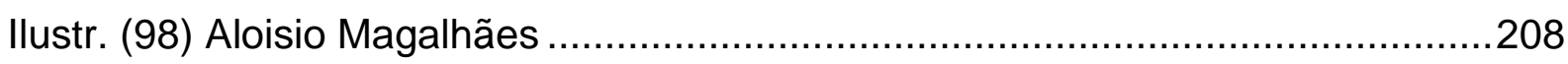

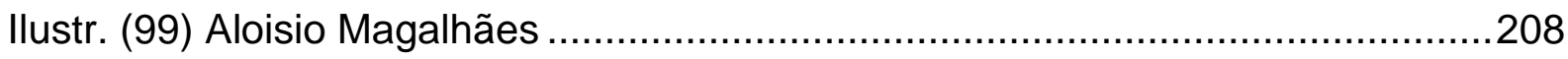

llustr. (100) Página do livro Doorway to Brasilia, 1959 .....................................210

llustr. (101) Página do livro Doorway to Brasilia, 1959 ......................................210

Ilustr. (102) Página do livro Doorway to Brasilia, 1959........................................211

Ilustr. (103) Página do livro Doorway to Brasilia, 1959.........................................212

llustr. (104) Página do livro Doorway to Brasilia, 1959.......................................213

Ilustr. (105) Página do livro Doorway to Brasilia, 1959.........................................213

llustr. (106) Páginas do livro Doorway to Brasilia, 1959.....................................214

llustr. (107) Página R do livro Doorway to Portuguese, 1957...............................215

Ilustr. (108) Página do livro Doorway to Brasilia, 1959......................................215

Ilustr. (109) Doorway to Portuguese, 1957 - Detalhe da capa e sobrecapa ............216

llustr. (110) Doorway to Portuguese, 1957 - Detalhe da capa................................216

llustr. (111) Folha de palmeira utilizada no experimento......................................217

llustr. (112) Folha gravada diretamente na chapa de offset, apenas com a exposição da luz do sol. 
llustr. (113) Detalhe da máquina processadora para revelação de chapa offset.....217 Ilustr. (114) Chapa revelada e pronta para impressão ........................................217 llustr. (115) Exemplo de gravação de cromo na mesa de luz ...............................218

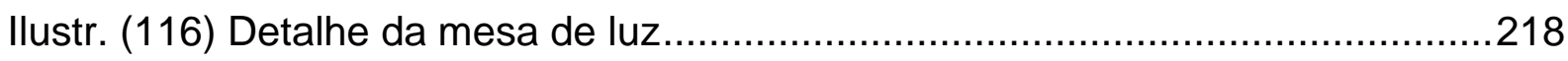
llustr. (117) Gravação da chapa em diferentes tempos de exposição.....................218 Ilustr. (118) Resultado da variação de exposição na gravação da chapa, utilizando o

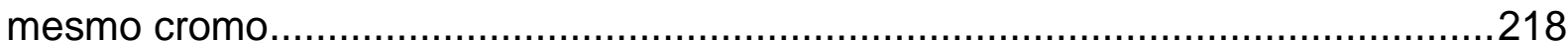

llustr. (119) Revelação da chapa na máquina processadora ...............................219

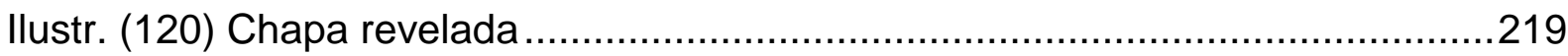
llustr. (121) Resultado da variação do tempo de exposição com o mesmo cromo .219 Ilustr. (122) Página O do livro Doorway to Portuguese, 1957 ................................220 Ilustr. (123) Página S do livro Doorway to Portuguese, 1957 ...............................221 


\section{LISTA DE TABELAS}

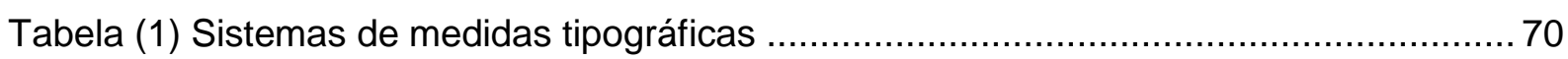

Tabela (2) Quadro de medidas tipográficas ............................................................ 88

Tabela (3) Quadro de evolução das medidas tipográficas .......................................... 89 


\section{SUMÁRIO}

\section{INTRODUÇÃO}

A. Momento histórico e justificativa na escolha do tema ................................ 15

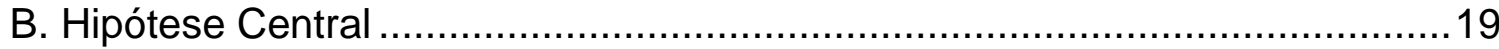

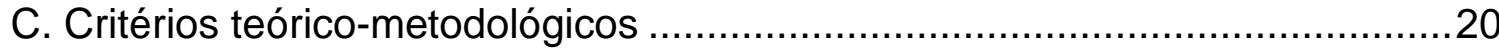

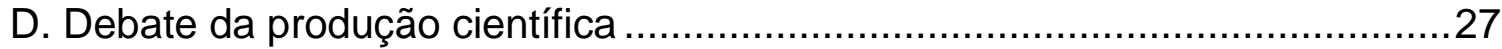

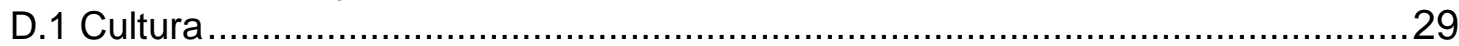

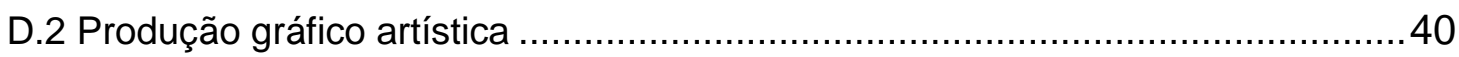

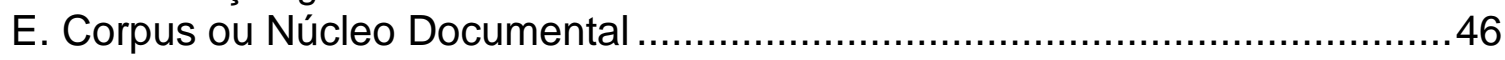

\section{CAPÍTULO I}

ALOISIO MAGALHÃES - PERFIL BIOGRÁFICO

\section{CAPÍTULO II}

TIPOGRAFIA: A TÉCNICA E A LINGUAGEM NA CONSTRUÇÃO DO LIVRO IMPRESSO 61

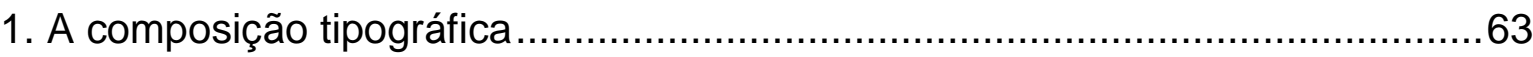

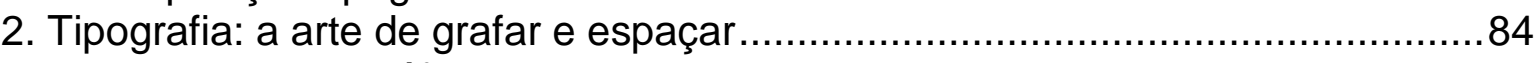

3. A linguagem tipográfica ....................................................................... 101

4. O tipógrafo: entre a arte e a ciência ....................................................119

5. A oficina tipográfica: o meio de produção como meio de linguagem ...............150

6. O Gráfico Amador como experimentação editorial .......................................157

\section{CAPÍTULO III}

ALOISIO MAGALHÃES E A LINGUAGEM GRÁFICA NO PROJETO EDITORIAL 166

\section{CAPÍTULO IV}

ALOISIO MAGAHÃES E EUGENE FELDMAN 
Uma cultura é avaliada no tempo e se insere no processo histórico não só pela diversidade dos elementos que a constituem, ou pela qualidade de representações que dela emergem, mas, sobretudo por sua continuidade. Essa continuidade comporta modificações e alterações num processo aberto e flexível, de constante realimentação, - que garante a uma cultura sua sobrevivência. Para seu desenvolvimento harmonioso pressupõe a consciência de um largo segmento do passado histórico.

Aloisio Magalhães 


\section{INTRODUÇÃO}

\section{A. Momento histórico e justificativa na escolha do tema}

A obra de Aloisio Magalhães é um grande legado à cultura brasileira. Não somente pela sua indiscutível qualidade expressiva, mas, principalmente, pela diversidade encontrada em sua trajetória. Nasceu em 1927, em Recife, e viveu até meados de 1982, após cinquenta e cinco anos de uma vida dedicada intensamente ao campo artístico e à cultura de nosso país.

Pintor expressivo de formas abstratas e paisagens, também foi artista gráfico e designer, criador de importantes projetos que contribuíram à formação do design brasileiro e que, desta forma, são hoje marcos de sua história. Tais projetos perduram ainda vivos em nossa memória gráfica e indicam todo aprofundamento e identificação de Aloisio Magalhães com a cultura brasileira. Sua trajetória o levou, naturalmente, já em uma fase adiantada de sua carreira, à vida política, onde, com grande respeito e dedicação, preocupou-se com questões relacionadas à identidade da cultura de nosso país.

Entre os anos de 1954 e 1961, participou junto a um grupo de intelectuais de Recife d’O Gráfico Amador, um ateliê gráfico que reunia pessoas interessadas na arte e produção do livro. Exploravam, para tanto, a composição tipográfica unida a outras linguagens artísticas e técnicas de impressão, como a xilo e litogravura, clichês de metal e barbante e pochoir ${ }^{1}$.

\footnotetext{
1 Au pochoir é o termo francês para stenciling, técnica de impressão que se utiliza de matrizes recortadas/ vazadas para a criação de figuras com uma ou mais cores. Cada figura ou cor é aplicada separadamente por meio de pinceis de pelo curto, esponja ou rolo para pintura. Faz-se uso de gabarito para obtenção de registro em projetos que contenham sobreposição de cores. Podemos aferir o emprego de tal técnica nos livros produzidos
} 
Tal produção editorial, sob cuidadosa forma gráfica - assim como relata o texto introdutório do primeiro boletim editado pelo grupo -, é marco histórico da produção gráfica brasileira e, com certeza, vanguarda do que se compreende enquanto moderna tipografia brasileira. Segundo Guilherme Cunha Lima²:

Durante quase oito anos $\mathrm{O}$ Gráfico Amador editou apenas quatro tipos de publicações, perfazendo um total de vinte e sete livros, três volantes, dois boletins e um programa de teatro.

Esses livros tinham como característica, além da pequena tiragem, o pequeno formato, sendo menores que o octavo. Como exceção, podemos citar a primeira edição de Ode, de Ariano Suassuna, que foi impresso in quarto. Outra exceção é representada pelas obras $O$ Burro de Ouro, de Gastão de Holanda e O Casamento Suspeitoso, de Ariano Suassuna, ambas da Editora Igarassu. Esses livros, contrariando a regra de pequenas tiragens de no máximo 120 exemplares, tiveram edições de 1.500 cópias.

O texto dos livros era impresso em tipografia. Para as ilustrações, utilizaram-se diversas técnicas de impressão: litografia, clichê de metal, xilogravura, clichê de barbante e pochoir. A composição era basicamente manual, mas em alguns casos partes do livro foram compostas mecanicamente (LIMA, 1997, p. 113, grifo do autor)

Entre 1956 e 1957 há um intervalo de tempo de grande relevância na cronologia histórica de Aloisio Magalhães, quando mora e trabalha nos Estados Unidos e conhece Eugene Feldman (1921 - 1975), artista gráfico e tipógrafo, cujo trabalho experimental baseava-se nas novas possibilidades técnicas de impressão offset.

pelo O Gráfico Amador, como também, na importante publicação de 250 exemplares realizada por Matisse em 1947, na sua obra Jazz.

2 LIMA, Guilherme Cunha. O Gráfico Amador: as origens da moderna tipografia brasileira. Rio de Janeiro: Editora URFJ, 1997. 
Aloisio Magalhães, interessado pelo museu de Filadélfia - Philadelphia Museum School of Art -, conhece também sua escola, onde mais tarde é convidado a lecionar. Assim, ao estender sua permanência no local, aproxima-se do trabalho de Eugene Feldman, então diretor do Departamento de Design Tipográfico da escola (1956) e inicia, desta forma, uma rica e conjunta experiência com esse artista no campo da experimentação gráfica. Utilizavam-se, para tanto, a The Falcon Press, gráfica offset cujo fundador era Feldman. Essa gráfica tinha, enquanto característica particular, sua atividade comercial durante o expediente de trabalho e servia de laboratório gráfico durante a noite.

Como fruto desse encontro, Aloisio e Feldman produziram e editaram dois livros: o primeiro em 1957, Doorway to Portuguese e, em 1959, Doorway to Brasilia. Essa produção, que se finda na experimentação gráfica desses dois artistas, é fonte primária da tese que aqui se apresenta e será parte fundamental da análise da produção gráfica de Aloisio Magalhães, visto que indica, a partir de sua produção, uma mudança em sua trajetória artística e profissional. Cabe dizer que a experiência com Feldman é tão significativa que, além de influenciar a sua produção em $O$ Gráfico Amador, sinaliza o direcionamento de Aloisio Magalhães para o campo do design, das questões implícitas ao projeto de design e, em específico, de como esta linguagem se insere no contexto de nossa cultura.

Desta forma, amplia-se sua experiência com as artes gráficas tradicionais e com o design de livros experimentais tendo em vista a sua participação em $O$ Gráfico Amador e seu contato com o graphisme francês que conheceu em sua visita a Paris no início dos anos 50 (DIAS LESSA, 2003). 
Importante ainda salientar que sua experiência nos Estados Unidos também o colocou em contato com o ensino de design norte americano, visto que a Philadelphia School of Art possuía tradição de ensino na área.

A pesquisa, portanto, centra-se na linguagem gráfica de Aloisio Magalhães, a partir de sua experiência em O Gráfico Amador, norteada pela questão da produção editorial no Brasil entre os anos cinquenta e sessenta, com enfoque no intervalo de tempo em que esteve em contato com Eugene Feldman, não somente pela importância do fato em si - que reverberou diretamente em sua linguagem gráfica mas, principalmente, por exercer a mudança em seu modo e propósito de criação artística. Tal passagem é decisiva para os rumos profissionais de Aloisio, pois nela se incide uma série de questões que serão discutidas no âmbito do projeto de design e da produção gráfico editorial a partir das novas tecnologias de impressão.

A escolha do tema tem, ainda, uma proximidade muito grande com a atividade profissional do pesquisador: a investigação no campo da linguagem gráfica. Isso se deve não somente à formação e atuação na área das artes gráficas e do design gráfico, mas principalmente, em seu trabalho como tipógrafo.

Deste modo, será tomado também como referência no campo de análise o material de ensino tipográfico levantado durante os últimos oito anos junto à Escola SENAI de Artes Gráficas, bem como a vivência no projeto da Oficina Tipográfica São Paulo. Tal projeto foi idealizado conjuntamente com o tipógrafo Claudio Rocha e o designer Claudio Ferlauto e se destina ao estudo e prática da linguagem tipográfica para o desenvolvimento de projetos gráficos experimentais. Assim sendo, será possível realizar a análise teórico prática acerca das linguagens recorrentes ao campo das artes gráficas, tipografia e design editorial que se inserem nessa pesquisa como objeto de estudo. 
Concluindo, esta pesquisa reúne levantamento dos principais métodos de ensino da prática da tipografia difundidos no Brasil, juntamente com a investigação de seus desdobramentos e adaptações para a cultura brasileira, visto que o trajeto percorrido pela produção gráfico editorial de nosso país teve no seu entrelaçamento com a história da tipografia brasileira, grande parte de sua delineação estética. Motivos esses tanto para análise da articulação técnica da produção - que interferiram no seu produto, e aqui especifico o projeto do livro - como, também, nos caminhos singulares formadores do projeto editorial em sua linguagem específica.

\section{B. Hipótese Central}

A presente tese tem, enquanto hipótese central, o diálogo estético artístico entre Aloisio Magalhães, o modelo internacional - proposto no campo do design gráfico pela escola suíça - e a moderna tipografia brasileira a partir de sua experiência junto ao grupo $\bigcirc$ Gráfico Amador. Tal hipótese partirá do argumento da existência do paradoxo vivido por Aloisio Magalhães em O Gráfico Amador, entre a atividade experimental no campo da produção de livros e os modelos clássicos de diagramação editorial existentes no Brasil nas décadas de 50 e 60, a partir de sua experiência com Eugene Feldman e vivência na Philadelphia School of Art. Após essa vivência, Aloisio estabelece novo entendimento e curso à sua prática artística, contribuindo de forma decisiva ao início e construção da atividade profissional de design gráfico no Brasil.

Cabe ainda dizer que a presente tese tem como objetivo, a partir de sua hipótese central, sobrepor questões relacionadas à cultura e identidade brasileiras, no campo da tipografia e do design gráfico, representadas pelo projeto editorial 
brasileiro. Para tanto, serão pontos de partidas dessas linhas de pesquisa a abordagem do fato histórico em si, no qual se insere o objeto de estudo. Deste modo, será aprofundada a verificação de como se estabeleceram os parâmetros utilizados por Aloisio Magalhães na criação e composição gráfica de seus projetos, a partir da deglutição dos valores por ele vivenciados em escolas estético artísticas estrangeiras, e de como esses, por conseguinte, propuseram-se em nossa cultura.

\section{Critérios teórico-metodológicos}

A pesquisa se fundamenta na análise descritiva e qualitativa dos dados, buscando explicitar, debater, confrontar e ampliar o conhecimento da formação do design gráfico brasileiro a partir do aprofundamento do tema proposto. Será centro e objeto de estudo, o trabalho de Aloisio Magalhães nas décadas de 50 e 60, período esse, como já apontado, de extrema valia em sua produção, como também de implicação ao momento histórico de nosso país.

Tal pesquisa referenciar-se-á nas áreas da História da Cultura - atualmente denominada Estudos Culturais e Linguagens Artísticas -, História da Arte e Design Gráfico. Entre esses campos de estudo será estabelecida a intertextualidade por meio dos registros de autores e fontes pesquisados, com objetivo de uma abordagem ampliada sobre o tema proposto e condução de debate acerca dos problemas intrínsecos a tal estudo.

Tais diálogos têm na História da Cultura seu principal eixo de ligação e possibilidade de interdisciplinaridade, visto que a mesma, na contemporaneidade, abre esse caminho, tanto ao renovar as categorias de documento das abordagens 
temáticas e problemas históricos, como também, por ter ampliado a interlocução com outras áreas (BAIRON, 2002).

Com base nessa premissa, a presente tese divide-se em quatro capítulos.

No primeiro capítulo, Aloisio Magalhães - Perfil Biográfico, serão abordadas as principais etapas da vida de Aloisio, relacionadas diretamente à sua formação artística e profissional. Como sabemos, a trajetória de sua vida foi marcada por uma atividade plural e diversa no campo cultural e artístico, fato que lhe confere uma propriedade singular enquanto artista e na relação que se estabelece com a evolução de sua própria linguagem.

Desta forma, o primeiro capítulo será dividido de maneira a explorar as seguintes fases de sua trajetória: o início de sua atividade artística com o Teatro do Estudante de Pernambuco (TEP), a pintura, a gravura e sua participação em O Gráfico Amador, visto que, dentre as linhas de pesquisa que compõem esta tese, confere-se aos Estudos Culturais e Linguagens Artísticas a possibilidade de se levantar as particularidades linguísticas da criação e produção gráfica oriundos de nossa cultura.

$\mathrm{Na}$ trajetória de Aloisio, identificam-se claramente dois grandes estágios - que poderiam ser chamados, o primeiro, de plástico, e o segundo, de político - havendo em cada estágio dois tempos definidos: as experiências iniciais em pintura e gráfica (no Recife, até 1960) e o escritório de design (no Rio, de 1960 a 1975 - 1980) correspondem ao primeiro estágio; o Centro Nacional de Referência Cultural (em Brasília, de 1975 a 1979 - 1980) e a política cultural do MEC, ao segundo. Ao mesmo tempo os dois estágios - plástico e político - estão interligados em um mesmo ciclo, já que o CNRC foi uma consequência do escritório de design, na medida em que representou uma exacerbação e um novo estágio na busca da natureza do produto brasileiro. Seu trabalho plástico sempre teve um lado político, no sentido da conscientização e da ação pública, e seu 
trabalho político sempre teve um lado plástico, na idealização, na formalização e na própria matéria do trabalho. Na verdade, para ele, era tudo uma só coisa, em sua visão abrangente dos fenômenos, apenas as ênfases variavam, em cada momento e em cada contexto. (REDIG, 2003, p. 141)

Assim, a trajetória de vida de Aloisio Magalhães, bem como as questões ligadas diretamente às problemáticas propostas pelo artista e contidas intrinsecamente ao seu trabalho, nos permitem encaminhar e discutir os problemas que se desenvolvem no âmbito dos estudos de cultura e linguagem. Dentre eles estão a questão da identidade cultural brasileira, problemática percebida por Aloisio tanto pelo caráter de nação brasileira, como também, através do problema de diferenciação entre cultura mais jovem como a do Brasil, em contraposição às denominadas culturas mais consolidadas como as da Europa. Para ele, tal juventude se predispunha culturalmente muito mais à mudança do que à permanência, à invenção do que a preservação.

Aloisio iria lidar com dois polos distintos que estão sempre postos à frente no processo de intercâmbio cultural (FALCÃO, 1997): a conciliação entre a cultura nacional, local e o mercado internacional, global. Os projetos que Aloisio desenvolveu tanto em sua trajetória no campo artístico como no design, evidenciam seu encaminhamento posterior à política cultural de nosso país. Tais formulações, portanto, já estavam contidas em fases anteriores a esta última.

Deste modo, os critérios de análise das obras selecionadas, contemplarão atenção e aprofundamento nas particularidades de sua linguagem gráfica e de como esta se vincula à questão identitária da cultura brasileira no campo do design gráfico, em específico no que se refere à produção editorial. Tal análise tem como objetivo perceber na obra de Aloisio o artista plástico, gráfico e designer que o fez, neste 
sentido, ser filtro de qualidades culturais brasileiras e, portanto, agente desta mesma cultura.

No segundo capítulo, Tipografia: a técnica e a linguagem na construção do livro impresso, será realizada uma investigação no campo da tipografia e sua relação com o projeto do livro no Brasil. Serão debatidas questões referentes à composição tipográfica, conceitos acerca da estética da página impressa, bem como referências de escolas e modelos transpostos para nossa cultura.

Nessa análise o foco será a questão do aprendizado do ofício tipográfico no Brasil por duas vertentes: a primeira de modo documental, pelo levantamento de material pesquisado junto à Escola Senai Theobaldo De Nigris ${ }^{3}$ e a segunda, pelos depoimentos de antigos mestres do ofício que atuaram em oficinas tipográficas na cidade de São Paulo.

Neste momento da pesquisa será realizado debate com foco na questão do livro no Brasil. O centro desse estudo se concentrará na produção editorial e suas especificidades no que se refere à criação e delineação estética a partir do seu modo de produção na cultura brasileira, no período que compreende os anos 50 e 60 , fase de importantes mudanças nas estruturas sócio econômica e industriais do país e que se refletem nos produtos editoriais nacionais.

Será dado enfoque ao agente formalizador desse objeto, sua relação de interação no processo construtivo e, por conseguinte, concretizador de ideias editoriais. Essa personagem, como veremos, reveste-se na figura do tipógrafo em uma primeira fase da história do livro em nosso país.

\footnotetext{
${ }^{3}$ A primeira escola de Artes Gráficas do SENAI foi instalada em 1945. Em 1962, passou a se chamar Escola SENAI Felício Lanzara, em homenagem ao importante líder do setor gráfico. Em 1971, com a cooperação técnica da Associação de Construtores Industriais de Máquinas Gráficas e Afins (ACIMGA), da Itália, o SENAISP inaugurou o Colégio Industrial de Artes Gráficas (atual Escola SENAI "Theobaldo de Nigris", no bairro da Mooca, onde passou a oferecer o curso "Técnico em Artes Gráficas". Com a implantação em 1998, da Faculdade de Tecnologia Gráfica, o SENAI tornou-se a primeira instituição da América Latina a oferecer um curso superior nesse segmento. (Fonte: http://www.sp.senai.br/grafica. Acesso em out, 2011).
} 
Tal fato se confere na obra de Antonio Isidoro da Fonseca, na cidade do Rio de Janeiro, a partir de 1747 e um pouco mais adiante na obra do tipógrafo editor, Francisco de Paula Brito, que se iniciou na tipografia por volta de 1824.

Além desses, outro importante expoente das artes gráficas que imprimiu obras de extrema qualidade no período que antecede a chegada da corte no Brasil e, consequentemente, a instalação da imprensa régia na colônia, foi José Mariano da Conceição Veloso, tipógrafo de extrema capacidade na arte do ofício.

Tais personagens formarão um primeiro quadro histórico da pesquisa, que auxiliará na compreensão de como se disseminou a tipografia em nossa cultura. Uma história curiosa, repleta de particularidades e que revela dados importantes na formação da história do livro no Brasil.

Cabe ressaltar que na presente pesquisa os esforços não foram concentrados diretamente na história do livro no Brasil, e sim na relação de sua forma de construção e recepção a partir de seus agentes produtivos. Veremos, então, a importância da figura do tipógrafo e de suas implicações na feição estética do livro, de sua contribuição junto à construção do sentido e significado em projetos editoriais.

Ainda neste capítulo, voltado à questão das linguagens técnicas de produção do livro, veremos o aparecimento de outro importante agente nesse processo. Como no século XIX encontramos, na figura do tipógrafo, a razão maior do processo de construção do livro e, consequentemente, na construção de sua identidade, veremos o surgimento do artista gráfico - produtor no século $X X$ a serviço das principais editoras. Será dele o planejamento gráfico que estabelecerá o padrão e aparência física do livro brasileiro (HALLEWELL, 2005). 
Portanto, a história de Aloisio Magalhães afina-se não somente com a discussão do projeto editorial brasileiro - no que tange às suas singularidades no período compreendido entre 1950 e 1960 - mas, também, com o debate do próprio fazer gráfico. De um lado o produto, pensado e articulado quase que artesanalmente pela composição tipográfica e, de outro, com o advento das novas tecnologias de impressão, uma nova maneira de pensar e executar o mesmo projeto gráfico editorial.

Diante desse quadro, nos cabe questionar: qual seria o limite do termo "artes gráficas" empregado no livro? O papel e a atividade artística profissional de Aloisio Magalhães transitam nesse terreno. Por isso, essa é uma das questões principais a ser explorada neste capítulo, partindo de uma análise do entrelaçamento dos papéis exercidos pelo editor, pelo tipógrafo, pelo artista gráfico e produtor e, por último, pelo designer.

No terceiro capítulo, Aloisio Magalhães e a linguagem gráfica no projeto editorial, se propõe a investigação da linguagem gráfica de Aloisio Magalhães a partir do enfrentamento das principais questões levantadas no campo da tipografia e que, desta forma, permitirão aprofundamento do estudo que aqui se apresenta.

A análise da linguagem gráfica utilizada por Aloisio será feita a partir das obras por ele realizadas, primeiro como pintor e depois como integrante d'O Gráfico Amador. Tal análise é um meio de melhor compreendermos a criação, linguagem e composição gráfica, construídas pelo artista gráfico e sua importância dentro do contexto histórico cultural de nosso país.

Devido à sua importância no conjunto de técnicas empregadas por Aloisio Magalhães em seus projetos gráficos e ilustrações, as técnicas de impressão (litografia, clichê de metal, xilogravura, clichê de barbante e pochoir) também serão 
foco deste capítulo. Tal análise terá, como função primeira, elucidar a fluência de Aloisio no uso dessas técnicas e como ele as empregava em seu trabalho gráfico.

A reunião desses sistemas de impressão, além de evidenciar o campo referencial de análise proposta, nos permitirá melhor compreender o dimensionamento do trabalho de Aloisio Magalhães. Isto é, de como esses sistemas de impressão foram por ele explorados - tanto em suas particularidades quanto em seu intercambiamento - e, desse modo, criaram o sentido de sua linguagem experimental.

No quarto capítulo, Aloisio Magalhaes e Eugene Feldman, serão tratadas as questões relacionadas ao diálogo que se estabelece entre a experimentação gráfica de Aloisio Magalhães e Eugene Feldman na The Falcon Press, Filadélfia EUA. Serão discutidos e investigados os processos criativos, técnicos e linguísticos entre esses dois artistas gráficos, bem como suas referências de linguagem.

Essa experiência vivida por Aloisio é de grande importância na investigação de seu modo de criação e produção artística, visto que o encontro com Feldman e o contato com as novas tecnologias de impressão provocam uma mudança em seu raciocínio criativo. Aloisio estabelece, a partir de então, uma ligação entre o modo de pensar e produzir do ofício tipográfico com esse novo sistema de impressão, que adentra em uma nova dimensão de escala reprodutiva e muda o sentido de projeto. Requer uma nova postura e articulação do fazer gráfico. O sentido de projeto agora Ihe aponta para o projeto de design.

Aloisio Magalhães, nesse sentido, percebe a oportunidade de mudança no alcance daquilo que cria e produz. Sua atitude projetiva agora se volta para o coletivo, para um tipo de projeto gráfico com outras implicações em relação ao campo artístico. 
Como fruto do encontro de Aloisio com Feldman, duas obras serão analisadas: "Doorway to Portuguese" e "Doorway to Brasília", ambas realizadas neste período: a primeira em 1957 e a segunda em 1959.

\section{Debate da produção científica}

Os autores que pesquisam a obra de Aloisio Magalhães convergem suas linhas de pesquisa principalmente nas questões relacionadas ao campo da linguagem gráfica e de como essa, por sua vez, na cronologia histórica de nosso país, desencadeou-se na formação do design gráfico.

No entanto, é importante ressaltar que a diversidade encontrada na vida e obra de Aloisio permite aos estudiosos do assunto tecer os seus conteúdos de pesquisa relacionando-os a momentos distintos de sua vida: no campo das artes plásticas com a pintura; no campo da gravura e das artes gráficas; na área do design editorial de livros experimentais; no campo dos projetos de design desenvolvimento de marcas e, por último, no campo da política cultural brasileira, que levou Aloisio a tratar de questões de extrema importância na política brasileira, como é o caso da questão dos bens culturais.

Todavia, independente da fase a ser recortada, em uma pesquisa sobre Aloisio Magalhães se reflete o seu comprometimento com a cultura de nosso país, visto que as questões que o político Aloisio defendeu já despontavam no início de sua carreira enquanto artista, como nos aponta Leite:

[...] a ele interessava a participação, como ator e observador crítico, nos e dos seus traços mais característicos [...] pensador assistemático, mas assíduo observador, do Brasil, Aloisio Magalhães 
usufruiu de um lugar especial onde ele mesmo se colocou para observar e agir sobre o nosso país [...]. (LEITE, 2003, p.21)

Assim, antes de desenvolver o debate da produção científica em questão, será retomada a divisão dos capítulos desta tese no intuito de compreendermos seu relacionamento com as linhas de pesquisa que permeiam o tema de pesquisa. A partir de então, faremos a aproximação das obras estudadas para que possamos, de fato, tirar proveito do debate da produção científica.

O primeiro capítulo propõe, a partir do levantamento biográfico, um painel detalhado acerca da formação artística de Aloisio Magalhães e o desenvolvimento de seu repertório no campo das artes plásticas, artes gráficas e, por consequência, seu encaminhamento ao design. Tem como objetivo principal estabelecer referências entre a formação cultural de Aloisio, o contexto histórico e percursos de sua vida profissional, no intuito de ressaltarmos os fatores que o levaram - em sua ação projetual - a contribuir para a formação do design gráfico no Brasil.

No segundo capítulo se apresenta a questão da linguagem gráfica e a tipografia no Brasil e como essas se desenvolveram junto ao projeto editorial. Como consequencia desse estudo, serão exploradas as especificidades do projeto editorial brasileiro, delineadas pela composição e impressão tipográfica. Será ainda analisado o meio de produção como meio de linguagem no aprofundamento da dinâmica de uma oficina tipográfica, com intuito de analisar a influência desse modelo de produção do livro e de como isso se relaciona com o trabalho de Aloisio Magalhães.

O terceiro capítulo está centrado na abordagem cultural, visando discutir a linguagem gráfica de Aloisio no recorte temporal entre os anos de 1950 e 1960. No plano da cultura, fundamentará questões e problemas relativos ao tema, a partir das 
principais linhas de discussão acerca dos estudos culturais e linguagens artísticas naquela época.

O quarto capítulo tem, por sua vez, a proposta de investigação das principais linhas de articulação da linguagem gráfica de Aloisio Magalhães e Eugene Feldman. Nele será explorado o encontro dos dois artistas na Filadélfia, no sentido de discutirmos os diálogos de linguagem que se estabelecem na sua produção conjunta, as obras: Doorway to Portuguese - publicado em 1957 e Doorway to Brasilia - 1959. Será ainda realizada neste capítulo uma análise específica de tais obras, bem como apresentada uma experiência posta em prática pelo pesquisador, retomando as técnicas utilizadas nessas publicações.

A seguir serão apresentados os principais autores e linhas teóricas utilizados na presente pesquisa.

\section{D.1 Cultura}

Inicialmente discutiremos os principais autores em cuja análise da obra de Aloisio Magalhães convergem questões importantes no que se refere ao plano cultural. Dentre o mote principal dos problemas emergentes, se destacam questões como a identidade nacional, no âmbito do produto cultural brasileiro; a linguagem gráfica do artista e os diálogos que se estabelecem com escolas estrangeiras; a experimentação gráfica e o desenvolvimento do projeto de design em nossa cultura e suas implicações.

A formulação desses problemas, relacionados à cultura brasileira, tomaram corpo na atividade política que mais tarde Aloisio veio a exercer. No entanto, é possível concluir que tais questões já eram foco de atenção na sua intenção de 
projeto, tanto artístico como de design. Esse fato surge como em matizes, desde seu início no campo das artes plásticas, no grupo O Gráfico Amador e, também, nos projetos de design que veio a criar em seu escritório, a partir de 1960, no Rio de Janeiro. Aloisio era comprometido com a cultura brasileira e isso se revela como algo da sua própria natureza.

Encontramos na obra de Guilherme Cunha Lima, O Gráfico Amador - As origens da Moderna Tipografia Brasileira (1997), um estudo minucioso acerca do grupo de artistas intelectuais que, reunidos em Recife, tinham como objetivo a arte de fazer livros, de publicar textos sob uma cuidadosa forma gráfica e que, nessa empreitada, formaram o que se autodenominou de O Gráfico Amador. Tal estudo revela questões fundamentais acerca das origens da moderna tipografia brasileira que, de certa forma, são precursoras do que veio a se instaurar como design gráfico no Brasil, anteriormente à implementação, em 1962, da ESDI - Escola Superior de Desenho Industrial.

A pesquisa de Lima (1997) aponta os principais antecedentes desse fato histórico relacionado aos movimentos e correntes artísticas que o influenciaram caso do movimento moderno no Brasil, com os desdobramentos da Semana de Arte Moderna e a poesia concreta, relacionada à comunicação visual. Dentre os principais pontos de sua abordagem acerca do modernismo no Brasil, Lima (1997, p. 19) destaca que: "[...] um dos mais importantes temas resultantes do relacionamento entre o modernismo brasileiro e as vanguardas europeias é o do nacionalismo". Ainda apoiado nas palavras do autor vemos que:

A leitura dos documentos e das obras literárias da fase heroica (1920 - 1930) revela terem sido múltiplos os caminhos de desenvolvimento desta questão, assim como o conceito de nacionalismo que, àquela época, receberia diferentes interpretações. 
O tema nacionalismo chama à baile três questões essenciais. A primeira, de ordem estética, é representada pela negação das formas estabelecidas propostas pelo academicismo. A segunda, de ordem cultural, discutiu a dependência brasileira das matrizes da colonização europeia. E a terceira, de ordem política, questionou os benefícios do Estado como instituição necessariamente forte e centralizadora (LIMA, 1997, pp. 19-20).

Fundamentando esse tema, encontramos na obra de Arnaldo Daraya Contier, Brasil Novo - Música, Nação e Modernidade: os anos 20 e 30 um detalhado estudo sobre os problemas que envolveram a questão do nacionalismo e que tomamos como objeto de reflexão. Segundo Contier (1988, p. XII), “[...] o nacionalismo, em seus diversos matizes políticos e culturais, tornou-se vanguarda do pensamento brasileiro durante os anos 10 e 20, opondo-se, em muitas ocasiões, à política estabelecida pelos donos do poder na República Velha". Complementa ainda o autor que: "[...] sob o ponto de vista linguístico, preservou a tradição europeia dos séculos XVIII, XIX e dos inícios do século XX (impressionismo, em especial)".

Importante ressaltar que a aproximação da questão do nacionalismo nesse momento se dá no sentido de situarmos seu contexto preparatório ao panorama de problemas relacionados à identidade brasileira, discutidos de forma direta no trajeto profissional de Aloisio Magalhães.

Tanto em seu curso de atividades artísticas como em sua vida política, Aloisio sempre se preocupou em observar, com muita atenção, as particularidades de nossa cultura, dialogadas no campo da linguagem artística e também na questão da preservação e reconhecimento de nosso patrimônio cultural. Tal afirmação é comprovada pelas principais diretrizes encontradas na criação do CNRC - Centro Nacional de Referência Cultural, projeto idealizado por Aloisio em 1975, que tem 
como alicerce as questões formuladas por Mário de Andrade no seu anteprojeto do SPHAN - Serviço do Patrimônio Histórico e Artístico Nacional, em 1936.

Na obra de Zoy Anastassakis, Dentro e fora da política oficial de preservação do patrimônio cultural no Brasil: Aloisio Magalhães e o Centro Nacional de Referência Cultural (2007) se encontra esse apontamento, voltado exatamente à aproximação dos interesses do grupo do CNRC com as questões dos modernistas de 1922. Segundo Anastassakis (2007, p. 60), "[...] a valorização das raízes populares na construção da identidade nacional era algo que Mário de Andrade já havia proposto no Anteprojeto do SPHAN, em 1936 [...]. Aloisio apenas retoma algumas das propostas de Mário de Andrade". Ainda complementa a autora que "[...] o que diferencia a sua proposta da modernista é que ele vincula o bem cultural a um valor econômico, apresentando assim, através da cultura, alternativas ao desenvolvimento do país".

Segundo Maria Cecília Londres Fonseca (2005, p. 144), os interesses do grupo do CNRC eram, em princípio, similares às questões dos modernistas de 1922, pois ambos os grupos buscavam "[...] atualizar a reflexão sobre a realidade brasileira e buscar formulações adequadas para a compreensão da cultura no contexto brasileiro contemporâneo".

Assim, como apontado no início deste debate, podemos concluir que a formulação dos principais problemas relacionados à cultura brasileira encontrados na obra de Aloisio - tanto nas artes gráficas como nos projetos de design - tomaram corpo em sua atividade política. Sua trajetória profissional indica esse comprometimento com o desenvolvimento da cultura de nosso país, e, portanto, as suas passagens de uma atividade a outra se revelam como uma tentativa do artista em alcançar progressivamente maior amplitude e atenção dentro desse contexto. 
Nessa trajetória podemos visualizar também a evidente busca do artista em ampliar cada vez mais a questão da coletividade em seu trabalho, postulação afirmada por ele mesmo em sua mudança da pintura para o design. Em depoimento contido na obra de Isis Fernandes Braga, Aloisio Magalhães: As Faces Culturais do Design no Brasil (2004, p. 74), Aloisio expõe seu pensamento: “[...] eu não acredito mais em arte individual. Tudo tem que ser coletivo, tem que atingir a coletividade.".

Observa-se, assim, que ao longo de sua carreira a passagem de uma atividade a outra sempre esteve entrelaçada a uma questão maior: a observação atenta das particularidades de nossa cultura e, desse modo, sua interação com ela e a promoção da mesma, sempre com fim ao coletivo. Daí lançar-se às atividades que exigiam dele esse tipo de interação cultural, como foi o caso da pintura para a produção editorial em $\mathrm{O}$ Gráfico Amador e desse para o design, culminando na atividade política de nosso país.

Na obra de Aloisio Magalhães, E Triunfo? - reunião de importantes textos do artista organizados por João de Souza Leite, Joaquim Falcão e José Laurenio de Melo - (1997, p. 115), encontramos seu entendimento face aos importantes acontecimentos e mudanças ocorridas em nosso país nas décadas de 1950 e 1960: "[...] uma espécie de fastio, monotonia, achatamento de valores causado pelo próprio processo de industrialização muito acelerado e sofisticado. O mundo começou a ficar chato". De modo comparativo com a culturas de outros países, Aloisio expõe o fato que:

Uma das consequências mais flagrantes do achatamento do mundo é a perda ou diminuição de caracteres próprios das culturas. Mesmo em contextos muito estratificados como a cultura japonesa, em que os elementos da cultura nacional são profundamente diferenciados, a diminuição e perda de valores próprios pela aceitação de valores 
mais universais é enorme. Se isso é válido em culturas já mais assentadas, imagine então o que acontece em países como o nosso.

Ainda na obra $E$ Triunfo?, no que se refere à questão cultural, vemos que as ideias de Aloisio (1997) partem do princípio que conhecendo a dinâmica das práticas culturais seria possível intervir positiva e adequadamente na realidade brasileira. Para tanto, se deveria fomentar o desenvolvimento baseado em elementos da própria cultura, ao invés de se criar algo a partir de modelos impostos externamente. Segundo Aloisio (1997, p. 51): "[...] uma cultura é avaliada no tempo e se insere no processo histórico não só pela diversidade dos elementos que a constituem, ou pela qualidade de representações que dela emergem, mas, sobretudo por sua continuidade". E a esse se soma o entendimento de que

[...] essa continuidade comporta modificações e alterações num processo aberto e flexível, de constante realimentação, o que garante a uma cultura sua sobrevivência. Para o desenvolvimento harmonioso, pressupõe a consciência de um largo segmento do passado histórico. (MAGALHÃES, 1997, p. 51)

Desse modo, observamos que Aloisio Magalhães se refere à questão do desenvolvimento de nossa cultura em relação às culturas externas, com atenção voltada para a identificação e preservação dos valores próprios a ela, para que dentro de um processo de crescimento e troca com outras culturas pudéssemos interagir, fazendo valer as particularidades de nosso saber local.

Isso se expressa na sua preocupação dentro de um programa de desenvolvimento, como se vê tanto na década de 1950 como também de forma acentuada a partir da década de 1970, quando questionado a respeito da identidade 
do produto nacional por Severo Gomes, ministro da Indústria e do Comércio na época.

Joaquim Falcão, ainda na obra $E$ Triunfo?, comenta que: "[...] nesta mesma linha, existem duas frases-síntese, extremamente seminais e de alto impacto mobilizador, que Aloisio gostava de repetir. Uma é: 'A homogeneidade é a inverdade'. A outra é: 'O universal não é o igual'.” (FALCÃO, 1997, p. 11). Partindo desse princípio, vemos sua extensão no que tange ao processo de globalização, seguindo o raciocínio do autor:

A primeira desenha a globalização como resultado de intenso pluralismo e respeito às diferenças, e combate monopólios culturais. A globalização verdadeira se distancia de qualquer ambição totalitária, de qualquer exclusivismo [...] já a segunda frase ' $O$ universal não é o igual' - não somente reafirma a primeira, como se propõe ir mais além. Não é tentando fazer o que os outros já fizeram que vamos ser universais. Não se deve confundir o processo de criação, que é necessariamente único, especial e local, com a disseminação desta criação, que pode ser ocasionalmente global. $O$ feliz paradoxo da globalização é que para ser vencedor global, nasce-se antes vencedor local. (FALCÃO, 1997, p. 11, grifo do autor)

Encontramos, portanto, nas obras aqui em debate, que cultura para Aloisio não podia ser entendida como fenômeno isolado, visto que seu entendimento parte da compreensão de cultura como algo que está em contínuo desenvolvimento e, desse modo, seus componentes se explicitam espontaneamente. Assim, "[...] ao realizar uma pesquisa sobre algum saber específico, implicava necessariamente, em observar e compreender todo ambiente que circundava a produção e reprodução de tal fazer." (ANASTASSAKIS, 2007, p. 84). 
Esse tipo de postura observadora e atenta aos aspectos de nossa cultura já estava na natureza de Aloisio como indivíduo e artista, como podemos ver na citação de João de Souza Leite, na obra A Herança do Olhar - O Design de Aloisio Magalhães, quando relata que:

[...] Aloisio foi a perfeita encarnação do homem cordial proposto por Sérgio Buarque de Holanda: um homem movido por afetos. Sua atenção fraternal balizada por comedida elegância no trato formal; o olhar amoroso às suas raízes familiares em Serra Talhada, no Sertão de Pernambuco, em oposição ao olhar curioso lançado sobre as grandes capitais ocidentais; o cultivo muito bem definido à própria individualidade contraposto à fruição de importantes criações populares coletivas (LEITE, 2003, p. 21).

Vemos, assim, que no vínculo que Aloisio possuía com a cultura brasileira, também pautado em sua trajetória de vida artística, se encontrava a referência natural dos valores autênticos - essência e originalidade - do que veio a produzir no campo da linguagem gráfica e mais tarde no design.

Retomando esse sentido, a obra de Contier (1988) ao tratar da questão dos nacionalistas no campo musical dos anos 1920 e 1930, já apontava a pretensão dos mesmos em encontrar a essência ou originalidade da música brasileira em oposição à música europeia, nesse mesmo sentido. Tal estudo também aponta as formulações traçadas por Mário de Andrade entre as possíveis conexões da música e folclore, privilegiando a cultura popular como centro da criação musical.

Seguindo essa linha de raciocínio, encontramos a ideia formulada posteriormente e publicada pelo então órgão da cultura dirigido por Aloisio - CNRC que propunha "[...] atributos como originalidade, tipicidade ou o artístico da arte popular constituem-se em reflexos da relação íntima dos processos e dos produtos 
artesanais com os peculiares contextos culturais em que se desenvolvem." (CNRC, 1976b: 05). Ainda sobre esse aspecto, encontramos na obra de Anastassakis (2007) o depoimento de Aloisio acerca do assunto:

[...] não é sem razão que, depois de quinze anos de trabalho como designer no Brasil, eu tenha me voltado para o projeto do CNRC, que considero como projeto de design. Pois se conseguirmos detectar, ao longo do espaço brasileiro, as atividades artesanais e influenciá-las, estaremos criando um design novo, o design brasileiro (MAGALHÃES, 1977, apud ANASTASSAKIS, 2007, p. 88).

Podemos aferir ainda na obra $E$ Triunfo? a questão postulada por Aloisio (1997) quanto aos bens culturais, a partir de seu entendimento de que o conceito de bem cultural, na época, ainda se restringia aos bens móveis e imóveis, que continham ou não valor criativo e eram impregnados de valor histórico. Tais bens eram essencialmente ligados ao passado ou pertenciam a uma categoria de criação individual espontânea como é o caso das obras que constituem nosso acervo artístico como a música, literatura, cinema, artes plásticas, arquitetura, teatro e que quase sempre tinham apreciação elitista.

Dessa maneira, Aloisio (1997, p. 24) aponta que: “[...] permeando essas duas categorias, existe vasta gama de bens - procedentes sobretudo do fazer popular que por estarem inseridos na dinâmica viva do cotidiano não são considerados como bens culturais".

Apoiando-nos nas afirmações do autor, podemos concluir que esses bens procedentes da cultura popular, além de não serem considerados como bem cultural, não eram utilizados na formulação das políticas econômica e tecnológica. No entanto, como enfatiza Aloisio: "[...] é a partir deles que se afere o potencial, se 
reconhece a vocação e se descobrem os valores mais autênticos de uma nacionalidade".

Dentre as questões importantes encontradas na obra $E$ Triunfo? que convergem com a discussão proposta por Anastassakis (2007), vemos também a problemática do produto brasileiro e sua relação com o campo projetual do design. Discutem os autores 0 fato de que o projeto de design deveria visar a compatibilização de duas áreas de atuação: de um lado o conhecimento técnico racional - razão - e, do outro, a criação. Dessa maneira, as boas soluções de projetos surgiriam a partir do esforço de diálogo desses dois polos e, portanto, iriam se alinhar à boa estratégia de desenvolvimento do produto no país, sempre considerando as soluções peculiares que o fazer nacional desenvolvia.

Ainda sobre a questão, encontramos em Anastassakis (2007), no que se refere a relação do design enquanto responsabilidade social, o fato de que, em suas pesquisas, o CNRC concentrava esforços em investigar e dinamizar a "inventiva brasileira" como meio de contrapor o processo de achatamento cultural que o mundo ocidental sofria. Como aponta a autora: “[...] tal 'inventiva' estaria depositada no 'homem do interior', o chamado artesão - caracterização discutida por Aloisio Magalhães quando se trata de sua aplicação à realidade brasileira." (ANASTASSAKIS, 2007, p. 87). Encontra-se aqui, portanto, a relação compreendida por Aloisio entre o artesão e o designer onde ele próprio aponta o fato que:

É possível até ir-se mais adiante e dizer que esta evolução na direção de uma maior complexidade, de uma maior elaboração, caracterizada por um alto índice de invenção, como sendo uma atitude de pré-design. Em outras palavras, o artesão brasileiro é basicamente um designer em potencial, muito mais do que propriamente um artesão no sentido clássico (MAGALHÃES, 1997, p. 181, grifo do autor). 
Na direção desse pensamento, Anastassakis (2007) aponta que o CNRC se valia das questões formuladas por Aloisio para o design brasileiro "[...] considerando os produtores dos saberes locais específicos como 'designers' - criadores, e valorizando as soluções criativas de que eles se valiam para desenvolver tais 'tecnologias de sobrevivência' ou 'pré-design'.” (2007, p. 87, grifo do autor).

É importante ressaltar a opinião de outros autores quanto à atitude projetiva de Aloisio que se espelha na condução dos trabalhos do CNRC. Joaquim Falcão (2003, p. 21) comenta que:

[...] inventor é quem consegue escapar do debate pachorrento do presente e antecipar o futuro. Não o futuro utópico, mas o futuro possível. Aloisio Magalhães era um programador - visual e depois cultural -, um projetista, um projetivo. Não se conflitava com o presente. Antecipava, moldava e inventava o futuro.

João de Souza Leite, em sua obra A Herança do Olhar - O Design de Aloisio Magalhães, também reúne uma série de depoimentos que dividem a obra de Alosio em sua diversidade de atuação. No campo do design, quanto à questão projetiva da qual Falcão (2003) assinala, Leite expõe a ideia de que "[...] design pode ser entendido como a atividade projetiva responsável pela definição das características dos objetos que povoam nosso cotidiano, não sendo, portanto, exclusivamente uma atividade profissional." (LEITE, 2003, p. 20).

Assim, aponta o autor, que a visão de Aloisio Magalhães quanto à prática do design era aquela emergente dos problemas provindos de nossa sociedade, da realidade e cultura locais. Esse modo de interação com nossa cultura é evidenciado pelo autor ao sugerir que, tanto o artista como o político Aloisio a praticava, 
naturalmente, não apenas devido à sua origem regionalista mas, principalmente, pelo fato de que era um assíduo observador da cultura brasileira. Trabalhou pensando nela e assim a promoveu. Segundo Leite (2003, p. 21):

[...] em constante transformação de si, e de tudo que se colocava ao redor, embora se mantendo o mesmo, assim era Aloisio. De tudo se alimentava, de tudo retirava ingredientes necessários a uma incansável atividade, ora dirigida ao campo das realizações pessoais, ora ao campo da ação pública.

Quanto à sua formação e atividade no design, Leite (2003, p. 22) aborda a questão apontando ao fato de que como designer Aloisio não elegera "[...] o partido sistematizador do design de origem suíço-alemã, hegemônico na implantação da atividade no Brasil, como doutrina. Nele existiu, reconhecendo entretanto ser da nossa história, dos nossos elementos, que se poderia nutrir uma ação mais poderosa.".

\section{D.2 Produção gráfico artística}

Dentre os principais autores que discutem acerca da produção gráfica de Aloisio Magalhães encontra-se, sem dúvida, Guilherme Cunha Lima. Sua obra, 0 Gráfico Amador, é referência não apenas pelo recorte do que foi este grupo de intelectuais interessados na arte do livro, como também pela investigação minuciosa das origens da formação da moderna tipografia no Brasil. Seus fatos e desdobramentos são relacionados ao início do design gráfico em nosso país, desvinculados à instituição da ESDI em 1963, como frequentemente apontam alguns historiadores da área do design. 
Lima (1997) traça os principais acontecimentos correlatos à formação do grupo (de 1954 a 1961), suas influências artísticas, movimentos estéticos do período como o modernismo no Brasil e os desdobramentos da Semana de Arte de 1922, além da poesia concreta. Seu estudo, ao abordar os predecessores de $\mathrm{O}$ Gráfico Amador, traça os principais percursos pelos quais caminhou a imprensa no Brasil: a Imprensa Régia, a imprensa em Pernambuco, o mercado editorial e, principalmente, a questão das gráficas/editoras particulares - Private Press.

Desse modo, o autor faz um minucioso estudo sobre a questão do desenvolvimento da linguagem gráfica do grupo $O$ Gráfico Amador que, sob cuidadosa forma gráfica, editava em primeira ordem a produção literária de seus membros: Aloisio Magalhães, Gastão de Holanda, Orlando da Costa e José Laurenio de Melo. Como aponta Lima (1997, p. 86, grifo do autor): "[...] O Gráfico Amador foi fundado porque o grupo desejava publicar seus próprios escritos e o circuito comercial não Ihes era acessível [...] o preceito central, o de só publicar livros 'sob cuidadosa forma gráfica', foi observado rigorosamente até o fim.".

Lima (1997) nos traz, ainda, a questão da iniciativa do grupo frente a todas as dificuldades na publicação de um livro em Pernambuco. Desta forma se caracteriza a livre iniciativa editorial do grupo alinhada às chamadas private press - publicações que têm como característica a exploração do trabalho gráfico na integração formal entre o desenho da letra, o arranjo tipográfico, os ornamentos e ilustrações. Pode-se tomar enquanto modelo a Kelmscott Press de William Morris, ligado ao private press moviment, na Inglaterra, na primeira metade do século XIX.

A obra, O Gráfico Amador, revela o modo conjunto da produção editorial desse grupo, ou melhor, a questão da criação coletiva e de sua importância acima da individualidade, fazendo com que o grupo alcançasse uma identidade de 
linguagem muito refinada. Suas obras eram muito bem cuidadas e Lima (1997) aponta o fato de que uma das características do grupo, como metodologia, era justamente o trabalho entre o lúdico e o informal, mas que nem por isso deixava de ser rigoroso.

Lima (1997), portanto, trata da questão da linguagem gráfica atrelada à poesia, das técnicas por eles utilizadas e principalmente, de todo um corpo experimental, que se fez valorizar não somente pelo seu intento artístico de projeto mas, também, por sobrepor uma estrutura mínima de equipamentos. Através da pesquisa podemos refletir um modus operandi do grupo e principalmente rascunhar os caminhos por onde a produção gráfica editorial do período trilhou.

Apesar de consideradas experimentais, as publicações que foram produzidas pelo grupo $\bigcirc$ Gráfico Amador percorriam um tênue limite entre esse caráter primeiro e a diagramação clássica. Segundo Lima (1997, p. 174, grifo do autor), "[...] ao mesmo tempo em que tinham uma forte vocação experimental, não conseguiam se desligar de todo de uma diagramação clássica de maior aceitação pelo stablishment.". Ainda apoiado no mesmo autor e obra vemos que:

\footnotetext{
Esse impasse, que há de perdurar mesmo após o período de $\mathrm{O}$ Gráfico Amador, só será rompido por Aloisio que, ao retornar de uma temporada nos Estados Unidos, muda seu estilo de diagramação para o modelo internacional proposto pela escola suíça. Cabe observar que na Filadélfia, Aloisio trabalhou e foi possivelmente influenciado por Eugene Feldman, da Falcon Press (Idem, ibidem, p. 174).
}

Cabe ressaltar que a obra de Guilherme Cunha Lima trata do desenvolvimento da moderna tipografia brasileira ao revelar os percursos e questionamentos que esse grupo se propôs a enfrentar no campo do projeto editorial. Ao mesmo tempo 
em que vê no trabalho coletivo o desenvolvimento linguístico de sua proposta, consegue trazer as influências e repertórios individuais de seus integrantes, em destaque, Aloisio Magalhães.

Dessa forma, o caminho traçado por Aloisio nos revela os meandros por onde percorreu a própria história do design gráfico brasileiro - em uma época em que ainda era reconhecido como desenho industrial - principalmente por interligar outras histórias, como a relação do design brasileiro com escolas estrangeiras, movimentos estéticos artísticos e o contexto sócio político no Brasil.

O estudo minucioso de Guilherme Cunha Lima formula, ainda, o contexto entre os períodos em que $\mathrm{O}$ Gráfico Amador atuou e de como Aloisio veio a encaminhar posteriormente sua vida profissional no campo do design.

Os acontecimentos políticos desse período (1960 - 61) foram, sem dúvida, responsáveis pelo fim de O Gráfico Amador. Importa observar, no entanto, que o crescente profissionalismo de seus membros contrastava com a ideia de uma sociedade de amadores [...] o ano de 1964 foi o fim para esse grupo: seus membros se dispersaram, alguns ficaram no Recife, emigrando outros para o Rio de Janeiro e São Paulo [...] Aloisio é o primeiro a se desligar do grupo. Em 1960 transfere-se definitivamente para o Rio de Janeiro, onde abre um escritório de design. Depois disso se torna co-fundador da Escola Superior de Desenho Industrial, ESDI (LIMA, 1997, p. 174).

A obra de Guilherme Cunha Lima encaminha, por fim, as questões que se relacionam ao desenvolvimento do design a partir da década de 1960.

No que tange a ESDI e seu currículo de ensino, o autor aponta a influência e estreita ligação da escola com Ulm - Hochschule für Gestaltung. E isso se deve como relata o autor, às sucessivas visitas de Max Bill e Tomás Maldonado ao Rio de Janeiro estabelecendo, assim, um forte vínculo com os designers que ali se 
apontavam (LIMA, 1997). O autor cita, ainda, que: "[...] o modelo de Ulm exerceu influência decisiva no florescimento do design no Brasil. A participação ativa de Aloisio, já nessa época consagrado nacionalmente, no estabelecimento desse curso contou com a parceria dos primeiros designers do eixo Rio - São Paulo." (Idem, ibidem, p. 175).

Complementando as opiniões relativas ao período de implementação da ESDI no Rio de Janeiro, encontramos na obra A Herança do Olhar - O design de Aloisio Magalhães, importante depoimento no artigo escrito por Washington Dias Lessa (2003): “[...] o que acontece no Brasil é que este é o modelo que melhor se casa com as aspirações da época. Veiculado pelo concretismo e pela arquitetura moderna, engrossa o caldo do que então era chamado de vocação construtiva brasileira." (DIAS LESSA, 2003, p. 147). Ainda referente a essa questão, podemos ver que Dias Lessa (op.cit.) enfatiza que a postulação germânica de reconstrução do país no pósguerra estava se transfigurando aqui no Brasil, na vontade de construção original da modernidade a partir do nada.

Nesse sentido, se verifica pela continuidade do trabalho de Aloisio, que houve, de sua parte, uma melhor adequação desses modelos externos à nossa cultura. Joaquim Redig em sua pesquisa, Fundamentos do Design de Aloisio Magalhães - Design BR 1970, relata que "[...] o projeto Petrobrás reacende os próprios símbolos visuais da história da empresa, oriundos por sua vez dos símbolos visuais da história da nação [...] o que Aloisio fez depois na política cultural do país tem a ver com esta sua experiência com a linguagem visual brasileira." (REDIG, 2007, p. 16). Redig afirma, ainda, que:

Nossa grande luta interna na Esdi naquela época era para adaptar à realidade brasileira a metodologia e a ética técnica e social que então 
herdávamos da chamada Escola de UIm [...] como isso não era fácil, embora fosse desejo quase unânime, quando se atingia um impasse Aloisio reafirmava a proposta de parar de especular sobre o design ideal para o Brasil e passar a fazê-lo, para, a partir do feito, quem sabe, encontrar um novo caminho (REDIG, 2007, p. 134).

De encontro com esse raciocínio, vemos na obra $A$ Herança do Olhar - $O$ design de Aloisio Magalhães (2003) que Aloisio, na política, dava continuidade ao seu posicionamento frente à questão dos modelos externos à nossa cultura. Segundo ele, "[...] não nos parece possível nem viável qualquer tentativa de transplantação para nosso ambiente técnico e culturalmente diverso as ideias e o espírito que orientam qualquer das escolas existentes no estrangeiro". Continua o autor relatando que "[...] a afirmativa baseia-se não em preferências ou julgamentos, desta ou daquela escola, mas na percepção de que nossas condições exigirão solução própria, criada em função dos elementos circunstanciais com que lidamos." (MAGALHÃES, 2003, p. 144).

Outra importante análise a respeito das escolas estrangeiras e de sua influência no desenvolvimento do design no Brasil se encontra no artigo do designer e professor Chico Homem de Melo, que integra o conjunto de textos da obra $A$ Herança do Olhar (2003). Ao comentar o trabalho de Aloisio Magalhães na criação dos símbolos gráficos das grandes marcas por ele assim criadas, Homem de Melo (2003) afirma:

Quais são os traços característicos de sua produção nesta década? Abstracionismo geométrico, espelhamentos, reflexões? Nada disso. A fluência de seu desenho de linhas elegantes o leva a aproximar-se da gestualidade de um Miró ou de um Matisse nas ilustrações para $O$ Gráfico Amador. (HOMEM DE MELO, 2003, p. 152). 


\section{E. Corpus ou Núcleo Documental}

Obras realizadas na Filadélfia, The Falcon Press:

- Doorway to Portuguese, Aloisio Magalhães e Eugene Feldman, 1957.

- Doorway to Brasília, Aloisio Magalhães e Eugene Feldman, 1959. 


\section{CAPÍTULO I}

\section{ALOISIO MAGALHÃES - PERFIL BIOGRÁFICO}

Aloisio Magalhães nasceu em 1927 em Recife e viveu até meados de 1982, após cinquenta e cinco anos de uma vida dedicada intensamente ao campo artístico e de esforço à cultura de nosso país.

Sua obra é um grande legado à cultura brasileira, não somente pela indiscutível qualidade expressiva, mas, principalmente, pela diversidade encontrada em sua trajetória. Foi pintor de temas abstratos e paisagens, artista gráfico e designer; programador visual de logotipos e símbolos e criador do novo padrão monetário brasileiro.

Projetista e homem de visão privilegiada, sua grande atenção adentro de nossa cultura o levou naturalmente a ser fundador do Centro Nacional de Referência Cultural - CNRC. Nesse projeto demonstrou, já na época, seu grande respeito, dedicação e preocupação com as questões relacionadas com a identidade da cultura do país. Tal percurso o fez diretor do então IPHAN, Instituto do Patrimônio 
Histórico e Artístico Nacional mais tarde conhecido como Secretaria do Patrimônio Histórico e Artístico Nacional. Foi criador da Fundação Nacional Pró-Memória, para então, no cargo de Secretário da Cultura, ser referência ao plano de reformulação da política cultural do Ministério da Educação e Cultura.

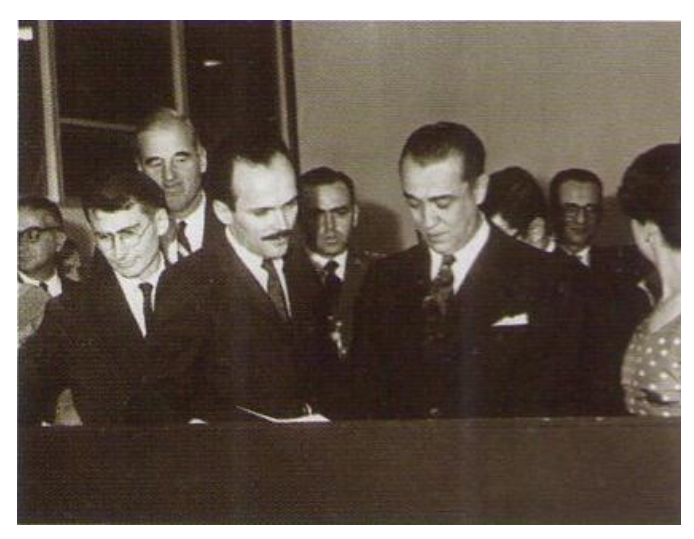

Ilustr. (1) Eugene Feldman e Aloisio Magalhães no lançamento do livro Doorway to Brasilia, com Juscelino Kubitschek Fonte: LEITE, 2003, p. 111.

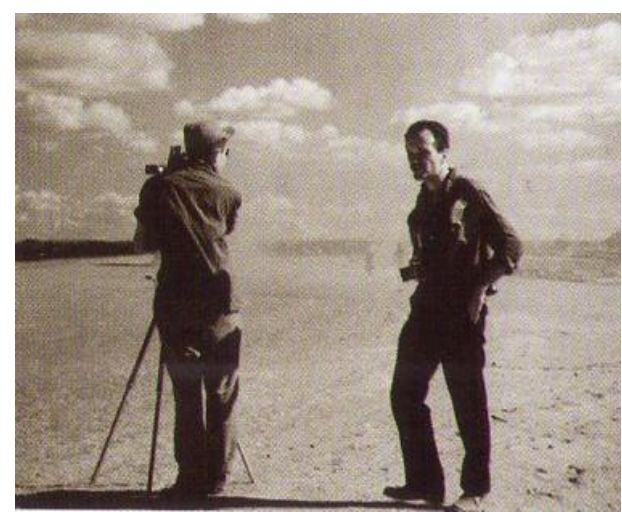

Ilustr. (2) Aloisio Magalhães e Eugene Feldman Fonte: LEITE, 2003, p. 110.

As linhas de articulação de seu trabalho político evidenciaram aquilo que o artista Aloisio sempre fora: um brasileiro, nascido e criado em berço de uma cultura extremamente regional, identificado de modo profundo com a nossa cultura e, desse modo, vinculado à questão identitária da cultura brasileira.

Vemos a obra de Aloisio Magalhães dividida por estes dois momentos de atuação: primeiro, enquanto artista plástico, gráfico e designer que o fez, neste sentido, filtro de nossas qualidades culturais e, portanto agente e produtor desta última. Em segundo, vemos o direcionamento de seu potencial criador e projetivo, direcionado à construção daquilo que o mais Ihe intrigava a investigar: a questão dos 
bens culturais no Brasil. A esse, iria somar-se, de modo conjunto, a problemática posta por Aloisio Magalhães quanto à questão da identidade cultural brasileira.

Segundo Aloisio, esse tema deveria ser percebido tanto pelo caráter da nação brasileira, como por meio da diferenciação entre culturas mais jovens, como a do Brasil, em contraposição a culturas mais consolidadas, de países mais velhos, como os Europeus. Para ele, essa juventude é o que iria nos predispor culturalmente muito mais à mudança do que à permanência e assim, seríamos motivados muito mais à invenção do que a preservação.

Deste modo, Aloisio iria lidar com dois polos distintos que estão sempre postos à frente no processo de intercâmbio cultural e, obviamente, dentro da problemática do tema globalização: como conciliar cultura nacional (local) e mercado internacional (global)? Na verdade, essas formulações já estavam inscritas na própria trajetória vivida pelo artista gráfico Aloisio Magalhães e articuladas em suas ações gráfico-experimentais pelos idos de 1954 com o grupo O Gráfico Amador.

Guardadas as proporções de tempo, a experiência vivida por Aloisio Magalhães junto àquele grupo de intelectuais em seu ateliê no Recife, já apontava um fazer e, consequentemente, uma produção artística que naturalmente lidava com algo intimamente ligado aos valores e índices autênticos de nossa cultura. Utilizavam a pintura, a xilogravura, o desenho, a tipografia, mesclados na construção de poesia e literatura.

Ao mesmo tempo, podemos afirmar que, ao trabalharem com o projeto de livro - como se reconhece na trajetória do grupo -, lidavam com um produto gráfico de cunho universal, com vistas à experimentação dentro de um plano singular e expressivo de nossa cultura. Tinham a intenção de que aquele fértil encontro 
investigativo entre seus idealizadores, adentro da experimentação gráfica no país, tivesse alcance e reconhecimento por parte do mundo editorial. E assim o fizeram.

Aqui cabe explanar um pouco mais sobre o sentido deste grupo e entender seu posicionamento no contexto histórico da época, para projetarmos um olhar atento à produção destes artistas e intelectuais autodenominados O Gráfico Amador. Grupo este que, entre os anos de 1954 e 1961, produziu, no Nordeste de nosso país, perto de trinta obras que vieram a se constituir enquanto marcos da história contemporânea da literatura, da arte e, em especial, do design gráfico no Brasil.

Nesse contexto, é muito importante entendermos que a trajetória da produção gráfica brasileira sempre esteve marcada por uma profunda confluência de estilos provindos de correntes estilísticas europeias e que o ofício gráfico aqui carecia, não somente de um suporte instrumental - tipos móveis, prensas e insumos gráficos -, mas também de quem estivesse disposto a uma tarefa maior de investigação acerca da própria linguagem e expressão gráfica. Diferente do que acontecia no velho mundo, não tínhamos tradição nessa área de conhecimento, mas a necessidade de sobrepor tais dificuldades, bem como a criatividade e talento de nossos artistas gráficos, sempre foi fator determinante para a construção de nossa história impressa.

Nesse âmbito de dificuldades, mas de muita vontade experimental, emerge a importância de grupos como $\mathrm{O}$ Gráfico Amador e de artistas como Aloisio Magalhães, que souberam transpor todas essas barreiras para se dedicarem não somente à simples tarefa de reprodução mas se cercarem de uma profunda razão investigativa, capaz de dar vazão a uma produção com pés fincados em nosso Brasil. Ou seja, uma produção gráfica editorial que estivesse preocupada em deixar transparecer nossa cultura, nossa forma de pensar com palavras, textos e imagens. 
Assim, é de considerável importância a contribuição cultural e artística de alguns de seus membros ao nosso país. Entre eles, como já fora citado: Aloisio Magalhães - designer gráfico, professor e um dos fundadores da Escola Superior de Desenho Industrial, ESDI, no Rio de Janeiro em 1963 e também secretário geral do Ministério da Educação e Cultura; Ariano Suassuna - romancista, dramaturgo, poeta e professor universitário, membro da Academia Brasileira de Letras; Carlos Pena Filho - poeta; Gastão de Holanda - designer gráfico, romancista e poeta, professor universitário e editor; Henrique Mindlin - arquiteto; Hermilio Borba Filho dramaturgo, romancista, fundador do Teatro de Estudantes de Pernambuco (TEP), e do Teatro Popular do Nordeste (TPN); José Mindlin - bibliófilo, industrial, decano da Federação das Indústrias de São Paulo; Sebastião Uchoa Leite - crítico literário, poeta e tradutor.

Esses foram, sem dúvida, alguns dos personagens que ali formaram, no Nordeste do Brasil, nos anos cinquenta, um dos mais ricos e intensos laboratórios de investigação e produção gráfica. Tal afirmação se cercam de documentos que registram correspondências mantidas por seus membros com editores de revistas especializadas, como é o caso de Walter Herdeg da Graphis de Zurique, Francis Harvey da Print de Nova lorque e Timothy Simon da Signature de Londres como relata Guilherme Cunha Lima (1997) em sua obra O Gráfico Amador, as origens da moderna tipografia brasileira. Vemos ainda apreciações de importantes intelectuais encontradas em artigos como Le Courrier Graphique, Paris - J.R. Thomé, Diário de Pernambuco, Recife - Mauro Mota e Correio da Manhã, Rio de Janeiro - Carlos Drummond de Andrade.

Essas apreciações, bem como estudos mais recentes, representam contribuições essenciais para a compreensão do design gráfico brasileiro e para 
uma melhor análise acerca dos espécimes gráficos aqui produzidos. Cabe portanto dizer que o foco desta pesquisa se estabelece não somente na qualidade técnica da atividade gráfica, mas, principalmente, no modo de ação projetual em si, ou melhor, de como nossa cultura se expressa graficamente. Desse modo, a atenção investigativa será voltada para a questão da construção da história brasileira no campo do design gráfico.

Como já foi apontado, a trajetória da vida artística de Aloisio Magalhães além de representar uma expressiva produção artística emergente de nossa cultura, acontece concomitante a importantes mudanças e transformações na vida social e política de nosso Brasil. Dentre elas, a mudança da capital com a construção de Brasília, e, portanto, como veremos, todo o contexto que cerca os anos 1950 e 1960 em nosso país.

O recorte desse período histórico nesta pesquisa sobre a produção gráfica de Aloisio Magalhães faz-se, justamente, pelo acompanhamento da produção e da postura do artista em relação às mudanças na estrutura sócio político cultural que o Brasil intentou nestas décadas. O sentido de projeto gráfico para Aloisio torna-se outro após seu encontro com Brasília. Ao mesmo tempo ocorre outro fato de extrema relevância na vida de Aloisio: a experiência vivida com Eugene Feldman na The Falcon Press, Filadélfia, entre os anos de 1956 e 1957. 


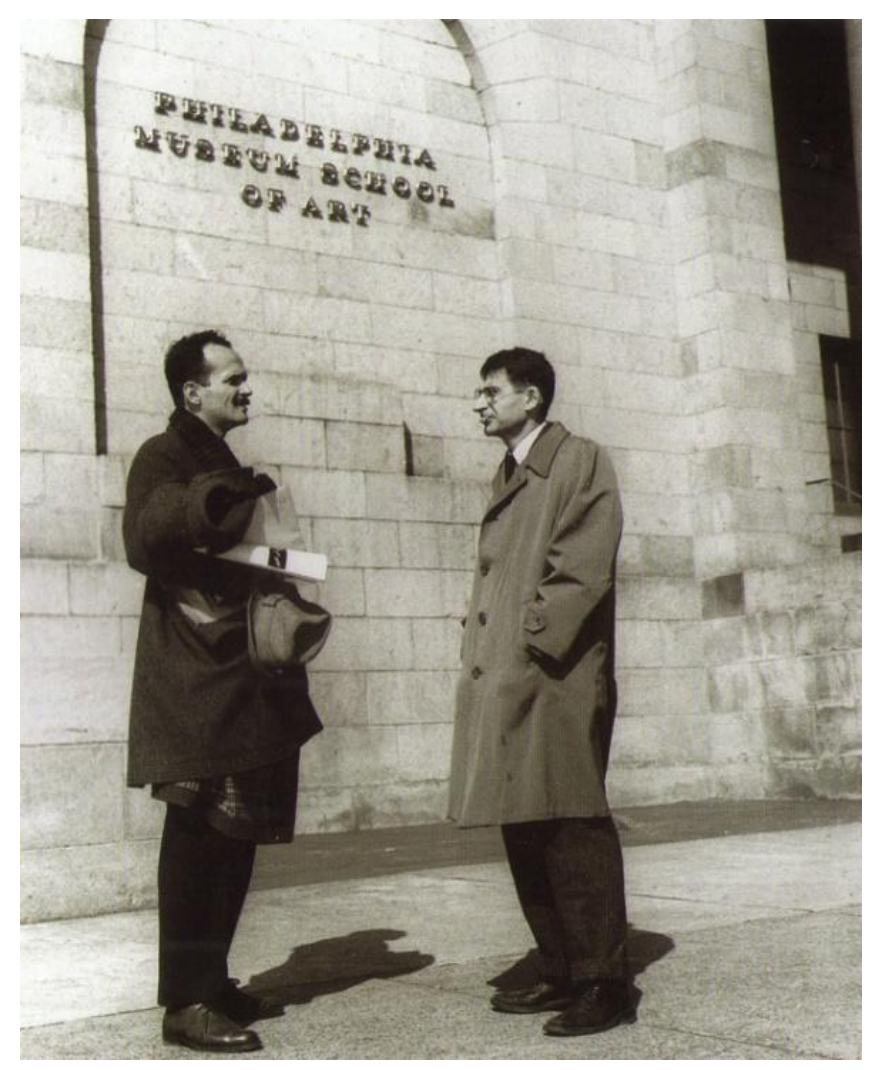

Ilustr. (3) Aloisio Magalhães e Eugene Feldman

Fonte: LEITE, 2003, p. 94.

Aloisio morou e trabalhou nos Estados Unidos nesse que foi um período de transformações marcantes quanto à sua concepção, criação e pesquisa técnica na área gráfica, levando-o a produzir, conjuntamente com Feldman, dois livros: Doorway to Portuguese e Doorway to Brasília. Esse último, como fruto da visita dos dois artistas a Brasília, proporcionou não apenas a pesquisa e concepção da obra, mas, também, novos rumos para a vida de Aloisio e seu entendimento sobre o que vinha a ser projeto. Tal revelação fora feita pelo próprio Aloisio Magalhães na época e sua história aponta essas profundas mudanças em seu curso profissional e a sua importante contribuição para a formação do design brasileiro.

A partir deste momento, a força criativa de Aloisio inicia um percurso no qual a sua expressividade se concentra na dimensão do projeto de design gráfico. Esse 
sempre fora para Aloisio um projeto de abrangência social e comprometido com nossa cultura, autêntico e verdadeiro, pois emergia de um processo natural de maturidade e aprofundamento do artista com essa mesma cultura.

Desse modo, não só a vida como a obra de Aloisio Magalhães torna-se objeto fecundo de pesquisa sobre cultura brasileira, em específico sobre nossa identidade no campo da produção gráfica e do design, do produto gráfico brasileiro e sua particularidade, posto que o entendimento acerca do projeto de design move-se enquanto sinalizador de sua cultura em tempo e espaço.

Ao refletirmos sobre o assunto, uma questão emerge com a devida importância: qual seria a característica identitária da linguagem do design gráfico no sentido de projeto e produto gráfico brasileiro? Essa identidade se dá a partir da deglutição de valores inscritos em nossa cultura, ou a partir de modelos de escolas estrangeiras, como é o caso da Europa e Estados Unidos? Ou ainda, em quais períodos de nossa história, podemos indicar movimentos autênticos que ambicionaram romper com modelos pré-existentes para realmente enxergar, traduzir e espelhar nossa cultura neste sentido?

O desafio e motivação para realização da presente pesquisa é justamente a oportunidade investigativa através da produção gráfica brasileira, visto que no campo da História da Cultura será possível encontrar caminhos de análise que sustentem uma profunda razão de interpretações, tanto no âmbito formal e estético da cultura gráfica, como também e, principalmente, em seu perfil histórico cultural.

Neste sentido, em maior amplitude, retomamos a estreita relação existente entre a escrita e a história dos homens, posto que, além de memória da humanidade, a escrita é o seu espelho, expressão direta do homem e da sociedade. 
Por consequência, o campo de estudo da escrita e da tipografia, assim como do produto editorial por ela gerado, elucida o percurso histórico do desenho e emprego das letras, que sempre se influenciaram por uma tríade de fatores: o instrumento, o suporte, a mão, sendo esta entendida enquanto cultura e seus agentes, determinados a partir de sua implicação temporal.

Desde o início da escrita, observa-se, portanto, o diálogo presente entre a condição interna e externa na delineação da estrutura de uma letra, uma escrita ou texto. Para o tipógrafo Adrian Frutiger em seu estudo Sinais e Símbolos, (2001, p. 160), “[...] a escrita deve ser considerada como a expressão do espírito de determinada época". Desse modo, podemos inferir que há um revestimento dos tempos, uma espécie de Zeitgeist contido na forma de cada família tipográfica, reinterpretando de maneira incessante seu lugar na condição social, política econômica e estética.

Vemos, assim, que a escrita de determinada época sempre procurou estabelecer elos com os recursos e possibilidades da qual se servia, como também, em sua estrutura formal, resplandecer seu diálogo com a cultura de sua época e o sentido estético presente nos campos da arquitetura, arte e música.

Frequentemente o formato dos caracteres é comparado a formas arquitetônicas. Também somos da opinião que o espírito e o clima intelectual de cada época se manifestaram no estilo arquitetônico correspondente, na escrita caligráfica e, posteriormente, nos livros impressos [...] em certo sentido, a história da escrita é uma 'grafologia' das culturas passadas [...] é surpreendente notar, por exemplo, como a concepção de espaço do arco redondo e de seu aparecimento em fileiras nas arcadas romanas encontra relação com a tendência ao arredondamento em quase todas as letras do alfabeto uncial da mesma época [...] também não podemos ignorar o fato de que o estreitamento característico do estilo gótico e a introdução da 
abóboda em forma de arco ogival revelam aspectos bastante semelhantes à escrita da mesma época, ou seja, Idade Média (FRUTIGER, 2001, pp. 139, 140).

Uma narrativa histórico cultural, portanto, pode ser referenciada tanto na construção de uma escrita como no conjunto de valores expressivos e formais encontrados em um projeto gráfico, um livro, uma edição. Constitui-se, então, uma prática de representação que nos fornece índices - e por que não sinais aprofundados e inscritos no organismo cultural a estes diretamente implicados.

Desse modo adentramos na investigação histórica que se enriquece ao seguir o fio de ligação das práticas e costumes culturais, pois, para Aloisio Magalhães, os bens culturais, sobretudo os bens procedentes do fazer popular, na dinâmica viva do cotidiano, são os valores mais autênticos de uma nacionalidade.

Portanto, a presente pesquisa aponta para um tipo de investigação que busca outro olhar para as questões até então expostas, referentes a cultura gráfica e sociedade. Nas palavras de Clifford Geertz em sua obra, A Interpretação das Culturas, vemos que:

Acreditando, como Max Weber, que o homem é um animal amarrado a teias de significado que ele mesmo teceu, assumo a cultura como sendo essas teias e a sua análise; portanto, não como uma ciência interpretativa, à procura do significado. É justamente uma explicação que eu procuro, ao construir expressões sociais enigmáticas na sua superfície [...] a maior parte do que precisamos para compreender um acontecimento particular, um ritual, um costume, uma ideia, ou o que quer que seja está insinuado como informação de fundo antes da coisa em si mesma ser examinada diretamente [...] todavia, isso nos leva à visão da pesquisa antropológica como uma atividade mais observadora e menos interpretativa do que realmente é [...] a análise é, portanto, 
escolher entre as estruturas de significação [...] e determinar sua base social e sua importância (GEERTZ, 1989, PP. 4, 7).

Apoiado em convergente linha de entendimento quanto ao vínculo existente entre sociedade, cultura e tipografia, Ladislas Mandel (2006, p.p. 11, 15), em sua obra Escritas - Espelho dos Homens e das Sociedades aponta que os historiadores e profissionais da escrita sempre tiveram a atenção "[...] mais voltada para a configuração exterior dos alfabetos do que para as relações profundas, ligando seus traçados aos homens e a seus meios culturais". Ainda discorre o autor que: "[...] o essencial reside na ação criadora do espírito humano, nos tesouros de sua sensibilidade e de sua cultura.".

Aloisio Magalhães foi filtro de nossa cultura. Foi um brasileiro nascido, criado e naturalmente introjetado em nossa cultura. Deste modo, o que criou, projetou e produziu, vinculou-se de maneira estreita com o sentido particular e próprio da cultura brasileira. Seu pensamento projetivo caminhava sempre em direção a enaltecer as qualidades culturais de nosso povo, de forma a perceber, ressaltar e assim potencializar tais características em seus projetos.

O que produziu, portanto, não representa simplesmente o seu modo criativo e operante, e sim, algo muito mais abrangente no sentido de índice cultural. $\mathrm{O}$ que pensou e criou nasceu a partir da observação de nossa cultura, que, como objeto valorizado, o devolveu para esta mesma cultura em forma de projeto, raciocínio e solução.

Para compreender um pouco melhor a produção de Aloisio Magalhães e a construção do sentido de seus projetos e vínculo com a cultura brasileira, serão traçadas etapas importantes dentro da cronologia de sua vida artística e pessoal, para depois esmiuçá-las no decorrer da pesquisa. 
Aloisio ingressa na faculdade de Direito da Universidade do Recife aos 18 anos, em 1946, e participa do Teatro do Estudante de Pernambuco (TEP), em que trabalha como cenógrafo, desenhando programas e também montando peças de mamulengo (teatro popular de bonecos).

Em 1951, ganha bolsa de estudo para o curso de Museologia no Louvre e frequenta, deste modo, em Paris, o Atelier 17 com Stanley William Hayter. Este atelier era uma espécie de laboratório experimental de artes gráficas por onde passaram importantes artistas como: Joan Miró, Hans Arp e Yves Tanguy. Trabalhavam-se diversas técnicas de gravura e este atelier se tornou importante pelo fato de resgatar essa linguagem no século XX.

Em 1953 percebe-se um momento distinto na carreira de Aloisio como artista plástico e suas obras ganham projeção internacional.

Entre 1954 e 1961, participa, no Recife, de O Gráfico Amador, produzindo junto a seus demais componentes: Gastão de Holanda, José Laurenio de Melo e Orlando da Costa, cerca de 27 livros, 1 programa de teatro, 2 boletins e 3 volantes. Na produção desse material a participação de Aloisio Magalhães se dá de forma mais efetiva nas seguintes obras e impressos:

- As Conversações Noturnas, poesia, de José Laurenio de Melo, 1954 llustração de Aloisio Magalhães.

- Ode, poesia de Ariano Suassuna, primeira edição in quarto, 1955 Ilustração de Aloisio Magalhães.

- Macaco Branco, Gastão de Holanda, 1955 - Ilustração de Aloisio Magalhães.

- Espaço e Forma, Aloisio Magalhães, 1955. 
- Memórias do Boi Serapião, de Carlos Pena Filho, 1955 - llustração de Aloisio Magalhães.

- Pregão Turístico do Recife, de João Cabral de Melo Neto, 1955 llustração de Aloisio Magalhães.

- Mundo Guardado, de Luiz Delgado, 1958 - Ilustração de Aloisio Magalhães.

- Improvisação Gráfica, Aloisio Magalhães, 1958.

- Aniki Bobó, João Cabral de Melo Neto, 1958 - llustração de Aloisio Magalhães.

- Volante N.3, Pergunta, 1958 - Design de Aloisio Magalhães.

- O Gráfico Amador, 1955 | Noticiário 1 - llustração de Aloisio Magalhães.

Nesse período há um espaço de tempo, entre 1956 e 1957, em que Aloisio mora e trabalha na Filadélfia, onde conhece o artista gráfico Eugene Feldman e, a partir de 1960, muda-se para o Rio de Janeiro e abre o seu primeiro escritório de design: AMPVDI (Aloisio Magalhães Programação Visual Desenho Industrial).

Em 1964 é aberto o seu segundo escritório, que existe até hoje, denominado PVDI. A partir de então, Aloisio produziu com sua equipe importantes projetos de identidade visual corporativa: o sinal da Light, em 1966; o sinal da Itaipu Binacional, em 1974; o sinal do Banco Boa Vista, em 1976; o redesenho das cédulas do Cruzeiro (moeda nacional), em 1979; entre outros. Mas, talvez, o sinal de maior destaque e projeção, tanto nacional como internacional, tenha sido o do IV Centenário do Rio de Janeiro, vencedor de um concurso público, em 1964.

Em relação à produção de Aloisio Magalhães neste período, Chico Homem de Melo aponta que: 
Nas exposições realizadas nos Estados Unidos, suas obras inscrevem-se na linguagem do abstracionismo informal, trilhando caminhos análogos aos de seu contemporâneo cearense Antônio Bandeira, para citar uma referência nacional.

Em resumo, se entendermos que a produção artística brasileira desse período aglutinava-se em torno de duas correntes principais, a construtiva e a expressiva, Aloisio, sem duvida, integrava a corrente expressiva. (HOMEM DE MELO, 2003, p. 151)

Na primeira metade da década de 1970 realiza livros experimentais voltados à iconografia histórica do Brasil e, a partir de 1975, envolve-se com a política oficial da cultura do Governo Brasileiro. É neste momento que funda o CNRC - Centro Nacional de Referência Cultural.

Em 1982 ocupava o cargo de Secretário da Cultura do Ministério da Educação e Cultura quando veio a falecer. 


\section{CAPÍTULO II}

\section{TIPOGRAFIA: A TÉCNICA E A LINGUAGEM NA CONSTRUÇÃO DO LIVRO IMPRESSO}

O capítulo que se apresenta tem por objetivo explorar as características singulares do ofício tipográfico e sua relação com o projeto editorial. Para tanto, foi dividido de modo a ressaltar e debater questões recorrentes nessa área de estudo e que convergem com a investigação dos problemas centrais a que esta tese se propõe. Dentre essas questões estão o campo técnico da composição tipográfica e a delineação de sua linguagem junto a construção do livro.

A figura do artesão, ou melhor, do tipógrafo, é colocada em discussão a fim de que se especule seu modus operandi e que, por conseguinte, seja viabilizado o debate das características singulares desse ofício no Brasil. Deste modo, a tipografia e o projeto editorial estarão compreendidos no recorte temporal das décadas de 1950 e 1960 para análise. 
Ainda com respeito ao mote de questões relacionadas à tipografia, neste capítulo será abordado o atelier tipográfico e o seu significado histórico na criação e construção do livro - o meio de produção enquanto meio de linguagem. Ao reconstruir a passagem da chamada arte tipográfica - cuja produção se caracterizava pelo modelo semi-industrial - para o modelo de produção industrial moderno, com o advento das novas tecnologias (entre elas a linotipia, a fotocomposição e o offset), vemos a reverberação destes enunciados junto às grandes transformações no campo editorial.

O distanciamento entre criação e produção gráfica então se acentua e faz com que o projeto editorial tome um novo curso no campo da criação e, consequentemente, de sua industrialização. Artes gráficas e tecnologia gráfica, a partir desse momento, sugerem um novo elo de interação.

Tais mudanças, evidentemente, influenciaram o modo de se pensar e projetar o objeto gráfico e, por consequência, o fazer gráfico. O papel do tipógrafo e sua interação com o projeto editorial se modifica. Abre-se um novo leque para os interatores da produção do livro que, como veremos, serão peças fundamentais para a criação da linguagem e identidade gráfica de importantes editoras. Dentre eles podemos citar, além dos tipógrafos, os artistas gráficos, os produtores gráficos e, mais tarde, os designers gráficos. Eles construirão o caminho da criação e da produção gráfica em si.

O debate da tese a partir deste momento se servirá da análise e caracterização dos papéis assumidos por esses profissionais, para que se reconheça os limites de atuação de cada um deles frente ao projeto editorial. Importante ressaltar que, por muitas vezes, como nos conta a história das artes gráficas no Brasil, podemos reconhecer múltiplos papeis assumidos por um só 
profissional ou artista, como é o caso de Aloisio Magalhães. Nesse sentido, a pesquisa propõe a investigação das singularidades da linguagem gráfica de Aloisio e o perfil de sua atuação junto ao projeto editorial, no intuito de que se reconheça a sua contribuição para o design gráfico brasileiro.

\section{A COMPOSIÇÃO TIPOGRÁFICA}

As referencias teóricas aqui utilizadas visam o entendimento da prática da composição manual na tipografia e a construção do impresso. A análise tem, enquanto função primordial, investigar a postura de Aloisio Magalhães frente à técnica da composição manual e como ele a empregava na produção de seu trabalho gráfico. Ressalta-se, ainda, que esta análise é um meio de melhor compreendermos a criação, a linguagem e composição gráfica construídas pelo artista gráfico e sua importância dentro do contexto histórico do livro em nosso país.

A origem etimológica do termo "tipografia" provém do grego, onde typos significa figura, marca, tipo e grapho escrever. Compreendemos, então, que a razão desse significado está vinculada à arte de representar o pensamento imprimindo por meio de caracteres móveis, também conhecidos, como tipos móveis. 


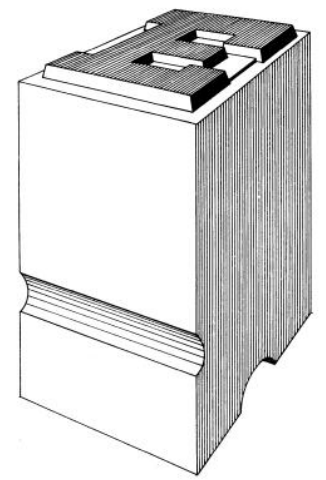

llustr. (4) Tipo móvel

Fonte: Apostila OTSP, 2010.

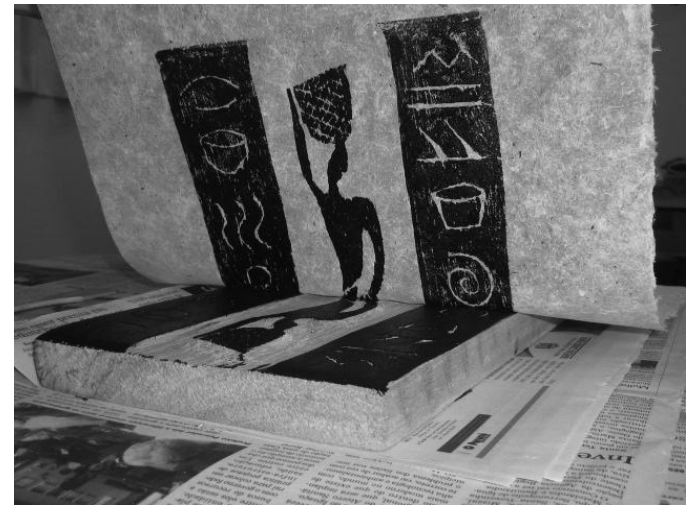

Ilustr. (5) Xilogravura

Fonte: Universidade Federal da Bahia

A história, como nos relata a interpretação dos fatos, situa a invenção da imprensa no século XV, na Alemanha (Mainz), por Johannes Gensfleisch zun Gutenberg. Segundo registros históricos, a invenção dos tipos móveis ocorreu no ano de 1441, porém, foi apresentada ao mundo no ano de 1451.

Gutenberg, observando a matriz de uma impressão xilográfica ${ }^{4}$, concebida em uma peça única, constatou que, se as letras fossem separadas individualmente, poderiam ser reutilizadas formando uma matriz. Portanto, é neste princípio que reside o conceito de fragmentação da matriz rígida em demais unidades (tipos móveis), que podem ser recombinadas de modo a criar novo bloco de texto ou matriz. O princípio que rege a composição tipográfica é tido enquanto base da teoria das partes intercambiáveis, sistema esse encontrado na constituição operacional do que veio a se chamar indústria. Segundo Allan Haley ${ }^{5}$.

\footnotetext{
${ }^{4}$ A xilografia ou impressão tabular era utilizada na China desde o século VI, e na Europa desde o século XII. Desenvolveu-se, porém, lentamente, e só no século XIV foi aplicada regularmente à reprodução de livros na maior parte dos quais compondo as legendas de imagens. Emprega-se o termo com o sentido de estampa feita com matriz de madeira e, também, como a arte de fazer gravuras com matrizes de madeira. Sobre esta placa o contra grafismo, ou seja, a área que na impressão não vai receber tinta, é encavado com ferramentas apropriadas, ficando em relevo somente o que irá ser reproduzido, como se fosse um carimbo, inclusive com a imagem na matriz gravada em posição invertida, tornando-se ilegível na matriz para ser legível no impresso.

${ }^{5}$ HALEY, Allan. Typographic Milestones. Nova York: Van Nostrand Reinhold, 1992, p. 10
} 
A maior contribuição de Gutenberg talvez seja o fato de que sua impressão alcançou um estado de eficiência técnica que não foi superado até o início do século XIX [...] Apesar de Gutenberg não ter inventado a maioria dos artifícios que lhe são creditados, sua façanha repousa na síntese científica de um produto prático e econômico. O molde ajustável, que Gutenberg de fato inventou, permitiu que um modelo produzido por um designer fosse repetido milhares de vezes. Isso também estabeleceu, três séculos antes de ser comumente adotado pela indústria, o princípio da teoria das partes intercambiáveis que é a base de todo produto moderno fabricado em escala (HALLEY, 1992, p. 10)

Assim, mais do que a invenção da imprensa, Gutenberg revolucionou o mundo apresentando um novo sistema. De acordo com Robert Bringhurst ${ }^{6}$ (2009) em sua obra Elementos do Estilo Tipográfico vemos que:

A metáfora básica da composição tipográfica é a de que um alfabeto (ou todo o léxico, no chinês) é um sistema de partes intercambiáveis. Nele, a palavra forma, em vez de ser reescrita, pode ser cirurgicamente revisada para transformar-se nas palavras firma ou fôrma ou forja ou força ou foram [...] a caixa de tipos do velho compositor tipográfico é uma bandeja de madeira subdividida que carrega centenas destes bits de informação intercambiáveis. Essas partículas subsemânticas, essas unidades chamadas de 'espécimes' pelos impressores tipográficos, são letras fundidas em corpos de metal padronizados, esperando pelo momento em que serão agrupadas em combinações significativas, depois dispersas e novamente recombinadas em outras formas. A caixa de tipos do compositor é um dos ancestrais primordiais do computador - e não é por acaso que a composição tipográfica, tendo sido um dos últimos ofícios a ser mecanizado, tenha sido um dos primeiros a ser computadorizado (BRINGHURST, 2009, p. 29, grifo do autor).

\footnotetext{
${ }^{6}$ BRINGHURST, Robert. Elementos do Estilo Tipográfico. São Paulo: CosacNaify, 2005, p. 29.
} 
Tal pensamento encontra força quando analisamos o ofício de um tipógrafo a partir, não só de seu manejo com os tipos, fios e vinhetas, ou seja, tudo o que grafa, mas, também, com os materiais que criam espaços na composição. Assim como na música, onde a composição se estrutura tanto com notas como com as pausas, a arte da composição tipográfica é a arte tanto de grafar como de espacejar (LUPTON, 2006).

O sistema de composição manual em tipografia reúne uma série de elementos, mas é no trabalho com os tipos e material branco ${ }^{7}$ (espaços: quadrados, entrelinhas, lingotes, lingões e guarnições) que reside o fundamento da composição e a habilidade de um tipógrafo. Transpor uma ideia manuscrita para uma composição em tipografia requer, em igual importância, conhecimento do manejo e compreensão desses dois elementos para se estruturar o que denominamos de fôrma tipográfica (composição do texto com tipos e espaços devidamente justificados e assim prontos para a impressão).
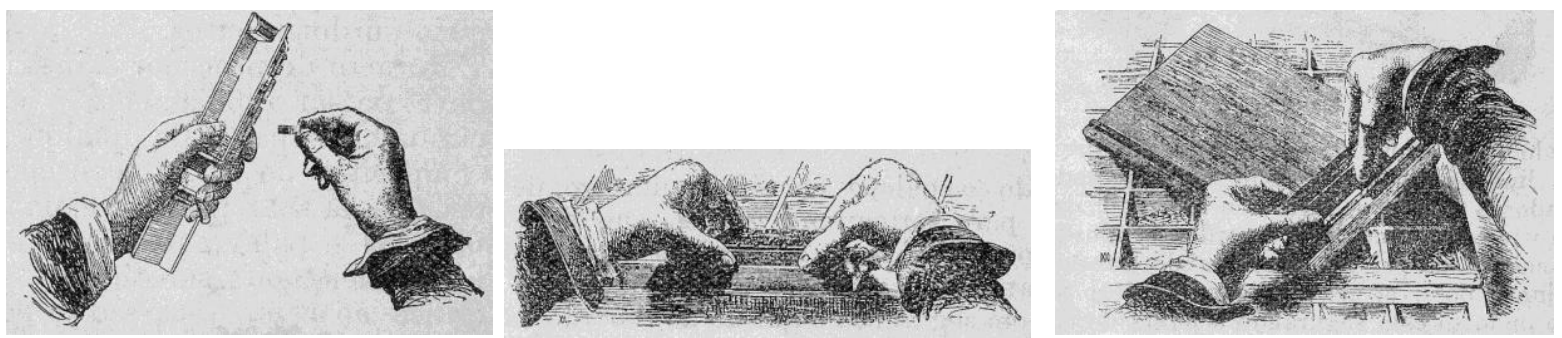

Ilustr. (6) Composição da forma tipográfica

Fonte: Manual do Typographo. Lisboa

\footnotetext{
${ }^{7}$ O termo "material branco" é utilizado na composição manual a todo material tipográfico de liga de metal ou alumínio, cuja função primeira é de criar espaços. Podem ser quadrados, entrelinhas, lingotes, lingões e guarnições, divididos em escalas de tamanho combinatório entre si e que possuem altura de 54 pontos ou 20,3 $\mathrm{mm}$ diferindo da altura dos tipos que é de $622 / 3$ pontos ou $23,5 \mathrm{~mm}$. Sendo assim, a rolaria somente entinta o material na composição de maior altura e padrão (tipos, fios e vinhetas) deixando os espaços sem entintagem, daí a procedência do termo.
} 


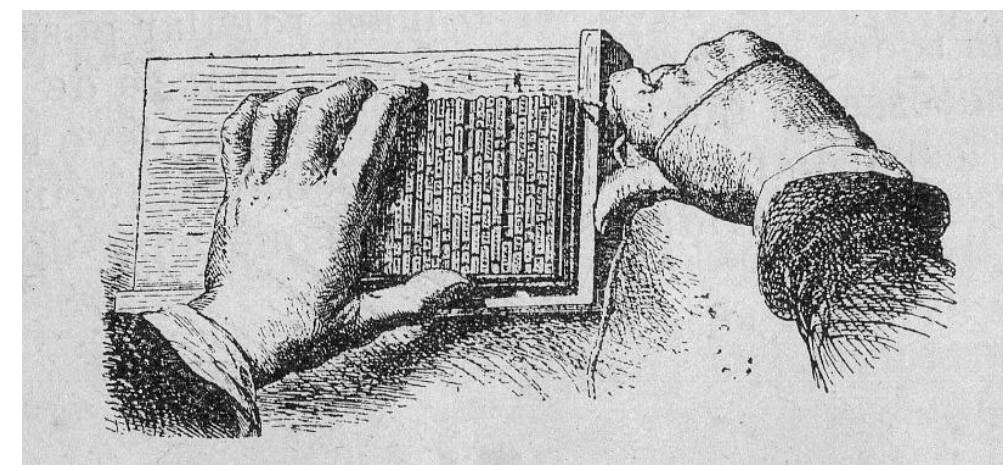

Ilustr. (7) Composição da forma tipográfica

Fonte: Manual do Typographo. Lisboa

Antes de detalhar as etapas das operações de composição e impressão tipográfica, voltaremos a atenção ao sistema de medidas que encontramos na tipografia, a fim de estabelecermos parâmetros referenciais ao nosso estudo.

O ponto é a unidade fundamental da tipografia. Define as dimensões de todos os materiais tipográficos e corresponde a $0,376 \mathrm{~mm}$. Sua história é curiosa, pois é resultado da evolução de várias tentativas em se estabelecer um padrão de medida a partir do material utilizado na tipografia.

Em 1723 o francês Martin D. Fertel idealizou, através de um Manual Prático de Tipografia, a primeira medida adaptável aos tipos, mas, infelizmente, tal intento não passou de uma sugestão. Foi a partir do trabalho do tipógrafo francês Fournier, com a publicação de seu Manualle Tipographique, mais completo do que o de Fertel, que se estabeleceu como mínima a medida que mais tarde se denominou "ponto" tipográfico - equivalente a 1/72 da polegada, que assim como a "braça" e o "pé" eram originadas do rei ${ }^{8}$.

\footnotetext{
8 "Pé de Rei" é a medida originária da convenção do comitê francês nomeado por Luis XIV durante o século $\mathrm{XVII}$, equivale a doze polegadas e assim como as representações da romain du roi (alfabeto do rei), refletiam a atitude científica do comitê real.
} 
Desse modo, o ponto de Fournier, que media $0,350 \mathrm{~mm}$, foi aperfeiçoado e intensamente aplicado, recebendo mais tarde o nome de medida duo decimal, pois a medida padrão era constituída de doze pontos. Assim, vemos a seguinte ordem de valores: o "pé de rei" equivalente a 12 polegadas, uma polegada igual a 12 linhas e uma linha formada por 12 pontos.

Em 1760, o gravador ${ }^{9}$, tipógrafo e impressor, Didot, aperfeiçoou a medida de Fournier e chegou a um ponto que media proporções mais reais e adequadas dos materiais e equipamentos tipográficos. O ponto Didot, também conhecido como ponto francês, equivale a $0,376 \mathrm{~mm}$ e a medida de doze pontos denominou-se cícero.

No Brasil, a medida que mais se difundiu foi a de Didot, também conhecida como sistema francês ou sistema Didot. Provavelmente, essa difusão se deu não somente pela influência da cultura francesa quando da colonização brasileira, como também pela maior adequação ao sistema francês de distribuição dos tipos móveis nas caixas de tipos. Existe uma diferença dessa última para outras existentes que se confere em relação à língua materna, de acordo com cada cultura, fazendo com que encontremos a caixa francesa, a caixa inglesa, alemã, por conseguinte.

\footnotetext{
${ }^{9} \mathrm{O}$ termo gravador ou engraver na língua inglesa, significa entalhador e no campo da tipografia, encontra-se na atividade de entalhar as letras. Para se fundir os tipos móveis era necessário primeiramente, entalhar o desenho das letras em uma punção para que esta formasse o baixo relevo em uma contra-punção. A partir desta, originava-se uma matriz que acondicionada em um sistema de molde, recebia a liga de metal. Tal processo poderia reproduzir várias unidades tipos móveis.
} 


\begin{tabular}{|c|c|c|c|c|c|c|c|c|c|c|c|c|}
\hline A & B & C & D & E & $\mathbf{F} \mathbf{G}$ & $\begin{array}{lll}\mathrm{A} & \mathrm{A} a ̈ \mathrm{e}\end{array}$ & Yi & $0 \ddot{0}$ & 10 & & $\mathrm{~N} \pi$ & $\mathbb{E} \approx$ \\
\hline $\mathrm{H}$ & I & $\mathbf{J}$ & K & L & $\mathbf{M} \mathbf{N}$ & A a E È & II & 00 & Ù & & $8 \mathrm{t}$ & $\% 1$ \\
\hline $\mathrm{O}$ & $\mathbf{P}$ & $\mathbf{Q}$ & $\mathbf{R}$ & $\mathbf{S}$ & \begin{tabular}{l|l}
$\mathbf{T}$ & $\mathbf{U}$ \\
\end{tabular} & 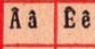 & Ii & 00 & $\begin{array}{ll}0 & 0\end{array}$ & & $11^{\circ}$ & $\{\&$ \\
\hline V & W & $\mathbf{x}$ & $\mathbf{Y}$ & $\mathbf{Z}$ & \begin{tabular}{l|l}
$\tilde{A} \tilde{a}$ & $\tilde{0} \tilde{0}$
\end{tabular} & Á á É é & il & 00 & $\begin{array}{l}0 \\
0\end{array}$ & ú & $\$$ & () \\
\hline 《》 & $\mathrm{j}$ & Ç C & inst & $m-$ & & 12 & 3 & 4 & 5 & 6 & 7 & 8 \\
\hline- & b & c & & d & $\theta$ & $\mathrm{s}$ & $\Xi$ & f & $g$ & $\mathrm{~h}$ & $\begin{array}{l}0 \\
\mathbf{k}\end{array}$ & $\begin{array}{l}9 \\
\text { W }\end{array}$ \\
\hline $\mathbf{Z}$ & 1 & $\mathrm{~m}$ & & & & & & & $!$ & ? & vets & voum \\
\hline $\mathrm{y}$ & 1 & $\mathrm{~m}$ & & II & 1 & 0 & $\mathrm{p}$ & 4 & ; & $:$ & wes & wasts \\
\hline $\mathrm{x}$ & $\mathbf{v}$ & $\mathbf{u}$ & & $t$ & espices & a & $\mathbf{r}$ & & , & . & & Alure \\
\hline
\end{tabular}

Ilustr. (8) Mapa da caixa francesa

Fonte: Apostila Senai, 1970

O ponto de Fournier ainda é utilizado na sua dimensão original, ou seja, 0,350 $\mathrm{mm}$ na Bélgica. Foi aperfeiçoado na Inglaterra e estendido, obviamente, à sua maior Colônia - os Estados Unidos - e passou a se chamar medida Anglo Americana, cujo valor é de 0,351 mm e que tem como somatória de seus doze pontos, a paica.

Com a evolução tecnológica dos sistemas de composição em tipografia, vimos, no final do século XX, a crescente exportação dessa tecnologia nos equipamentos eletrônicos de fotocomposição dos Estados Unidos, o que ajudou a difundir ainda mais a medida Anglo Americana. Já a medida francesa teve uma maior difusão em regiões de língua latina como América do Sul, Espanha, parte da Itália, Grécia, Alemanha, Suécia, Turquia, Áustria, entre outros. Existe uma quarta medida tipográfica utilizada na Holanda cujo nome é Santo Agostinho.

Vale ressaltar, portanto, que no Brasil o conjunto de valores adotados pelos tipógrafos se estabelece dentro do sistema francês, com suas convenções, como o ponto e o cícero. Exceção à regra é o que chamamos de furo, medida adotada exclusivamente em nosso país e que se originou do furo encontrado na parte interna 
dos lingões e que mede, coincidentemente, quarenta e oito (48) pontos ou quatro cíceros, como vemos na figura abaixo:

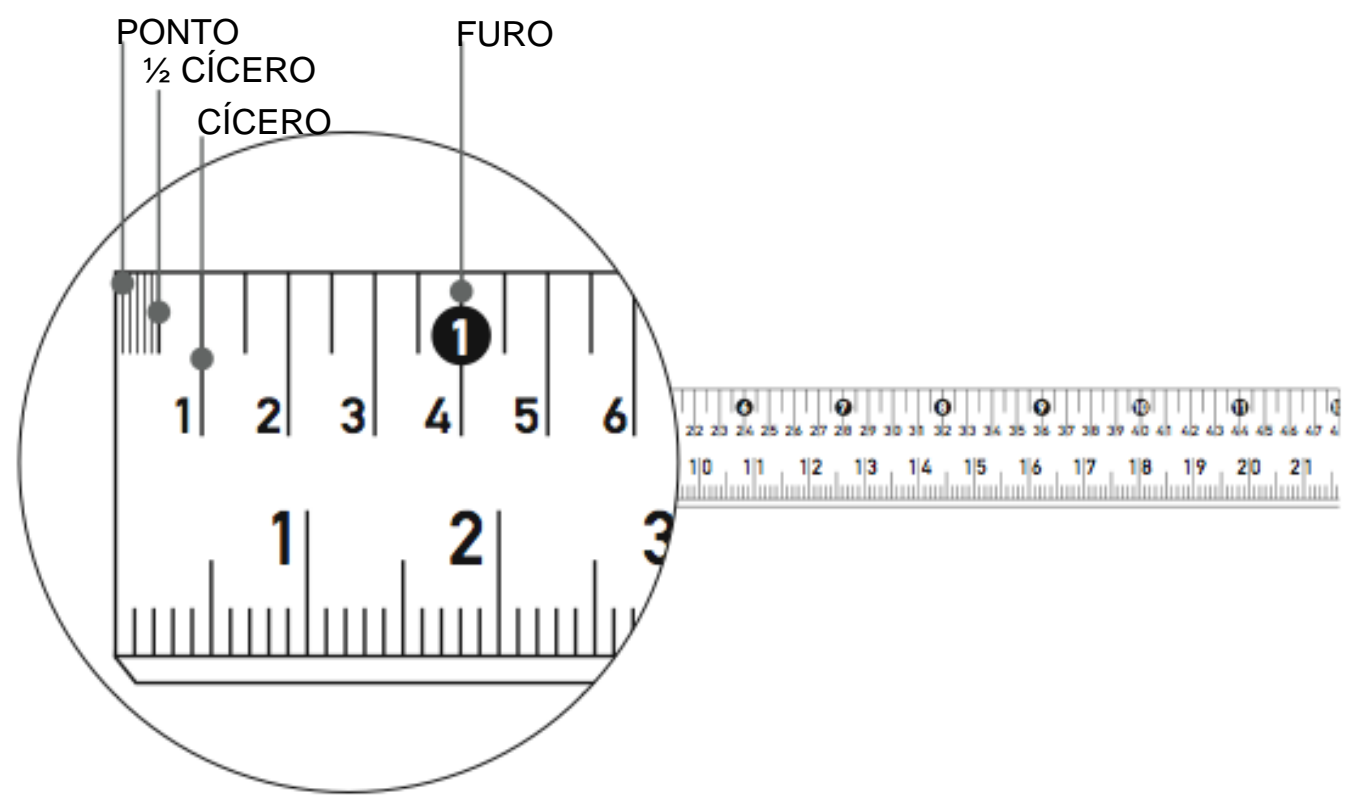

llustr. (9) Régua tipográfica

Fonte: Apostila OTSP, 2010

Como resumo desses valores, podemos ver comparativamente o seguinte quadro:

Tabela (1) Sistemas de medidas tipográficas

\begin{tabular}{l|l}
\hline Sistema Francês & Sistema Anglo Americano \\
\hline Ponto Didot $-0,376 \mathrm{~mm}$ & Ponto inglês $-0,351 \mathrm{~mm}$ \\
\hline Cícero $-4,512 \mathrm{~mm}$ & Paica $-4,212 \mathrm{~mm}$ \\
\hline Furo - 18, 048 mm (denominação brasileira) & \\
\hline
\end{tabular}

Fonte: Marcos Corrêa de Mello Felisette 
A convenção das medidas adotadas aqui no Brasil tem uma história bastante curta em relação a muitos países, principalmente europeus. Como sabemos, a imprensa, de modo oficial, chega ao Brasil em $1808 \mathrm{com}$ a vinda da corte e instituise a imprensa régia na colônia a partir de então.

As repercussões desse fato histórico de grande importância para esta pesquisa serão tratadas com a devida importância ainda neste capítulo. No momento nos restringiremos à abordagem teórica e técnica da composição tipográfica, na intenção de delimitar as referências de análise.

Os utensílios utilizados na composição tipográfica evidenciam o percurso da composição desde a montagem das linhas e fôrmas até a sua impressão. Permitemnos também, a partir da compreensão de seu uso e conjunto de regras, refletir sobre o raciocínio do projeto gráfico contido na página impressa e, nesse sentido, suas características formais e cursos de sua linguagem.

Esse é o foco de maior atenção a ser atribuído para essa temática nesse estudo, pois, a partir dessas questões será possível estabelecer relações entre as diferentes delineações da linguagem tipográfica encontradas nos movimentos artísticos e na história do design, pertencentes ao recorte de tempo a que este estudo se propõe.

O primeiro instrumento a ser utilizado pelo tipógrafo é o componedor. Ele serve para compor e justificar as linhas de composição. É formado por uma lâmina de metal na qual desliza um bloco móvel chamado justificador.

Portanto, a tarefa primeira do tipógrafo é retirar individualmente cada tipo da caixa tipográfica e compor a linha no componedor, devidamente ajustado em sua justificação. Ou seja, o tipógrafo deve, de antemão, estabelecer o escalonamento 
entre o corpo do tipo com a dimensão da linha a ser composta o que, por fim, criará uma mancha ou bloco de texto.

É nesse sentido que se estabelecem as medidas tipográficas dentro das séries de tamanho dos corpos de tipos em relação às linhas, dimensões de mancha de texto e formato de página. Assim concentra-se a lógica do projeto de um livro.

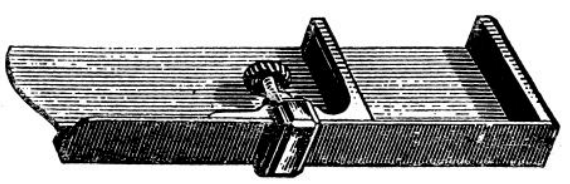

Ilustr. (10) Componedor Fonte: Apostila OTSP, 2010

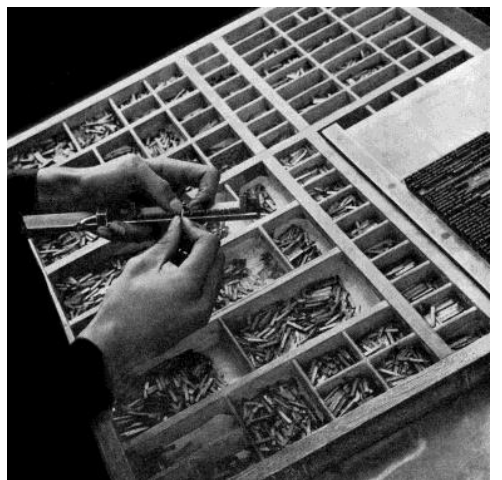

Ilustr. (11) Composição

Fonte: Cláudio Rocha, 2010

A composição tipográfica, portanto, lida com esse gerenciamento de escalas. Isto é, para compor, o tipógrafo tem atenção voltada desde a letra em suas características singulares como, também, de seu efeito no conjunto: a composição da palavra, de uma linha e, por consequência, do texto.

Essa lógica de construção muito se assemelha à estrutura que encontramos nos elementos da linguagem musical, onde temos, por sua vez, a relação: nota musical, intervalos, empilhamentos de intervalos formando acordes e sequência de acordes, delineando o campo harmônico da composição.

Compartilhamos, assim, da ideia de Lupton de que "[...] letras reúnem-se em palavras; palavras constroem sentenças. Em tipografia, o termo 'texto' é definido 
como uma sequencia contínua de palavras, distinta de legendas ou títulos mais curtos. O bloco principal é frequentemente chamado de corpo [...]" (LUPTON, 2006, p. 63).

\begin{abstract}
A tipografia ajudou a consolidar a noção literária do "texto" como obra original e completa - um corpo estável de ideias expresso de forma essencial. Antes da invenção da imprensa, os documentos manuscritos coalhavam-se de erros. Cópias eram copiadas de cópias, cada qual com suas próprias irregularidades e lacunas. Os escribas desenvolveram maneiras inventivas de inserir linhas faltantes nos manuscritos para salvar e reparar esses objetos laboriosamente preparados.

Substituindo o manuscrito copiado a mão, a impressão com tipos móveis foi o primeiro sistema de produção em massa (LUPTON, 2006, p. 65, grifo do autor).
\end{abstract}

Nesse fluxo de trabalho, a pinça tipográfica é utilizada para retirar os tipos das formas e fazer emendas, auxiliando quando é possível o uso dos dedos.

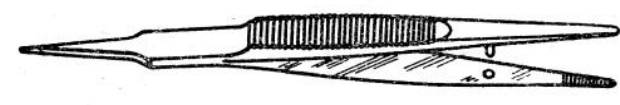

Ilustr. (12) Pinça tipográfica Fonte: apostila OTSP, 2010

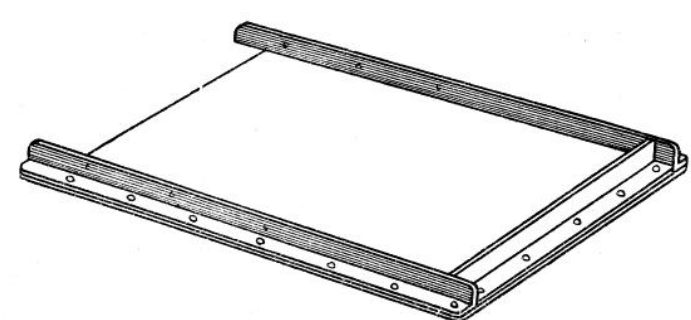

llustr. (13) Bolandeira

Fonte: apostila OTSP, 2010

A linha composta é transferida para a bolandeira, espécie de bandeja formada por um plano retangular com rebordos em três lados, com ângulos retos entre si. As linhas transferidas na bolandeira vão formar, junto com os espaços, a composição. 
As caixas de tipos são gavetas retangulares, feitas de madeira, com divisões e subdivisões internas para acondicionar os tipos. A disposição dos tipos utilizada no Brasil segue o modelo de caixa francesa, como já fora especificado, sendo dividida em duas partes: alta e baixa.

$\mathrm{Na}$ caixa alta são colocadas as letras maiúsculas, as ascendentes e os sinais gráficos e na caixa baixa se dispõem as letras minúsculas, as pontuações, os algarismos e os espaços naturais. Subdivide-se em 110 caixotins, sendo 56 na caixa alta e 54 na caixa baixa como mostra a figura:

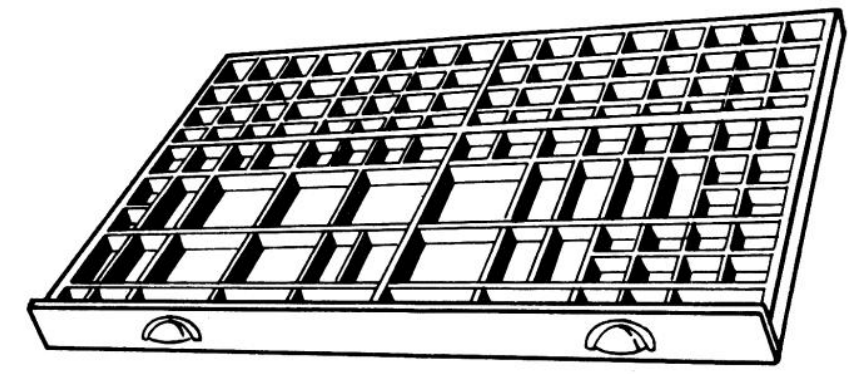

Ilustr. (14) Caixa de tipos

Fonte: Apostila OTSP, 2010

As caixas de tipos são guardadas em cavaletes, móveis de madeira próprios para tal uso, cujos tampos inclinados são utilizados como local de trabalho para apoiar gavetas de tipos e, principalmente, as bolandeiras durante a composição.

Essa informação é importante, pois, com o plano inclinado se deve montar uma linha após outra, dispondo-as em andares sucessivos até o final da composição. A construção de cada linha, portanto, obedece a ordem que vai da esquerda para a direita, da parte superior do que será impresso até sua margem 
inferior, para que se consiga, neste sentido, o espelhamento da matriz, ou chapa tipográfica, corretamente no papel.

O raciocínio da composição manual, em contraponto ao sistema digital, tem, portanto, algumas constatações de suma importância em seu modo operante. Depende de um planejamento prévio, bem como uma visão do conjunto do objeto gráfico, para que se obtenha a composição no sentido físico do termo. Como descrito, esse planejamento conta não somente com uma visão sistêmica de tais operações, mas, também, com a implicação direta do manejo deste material.

A composição manual constrói espaços e aquilo que será propriamente grafado, partindo-se de objetos físicos: ligas de metal em chumbo, antimônio e estanho, elementos esses que se movem antagonicamente em seu ato construtivo no digital, mas que tomam, enquanto referência de escalas de valores, a unidade comum da tipografia, o ponto tipográfico.

No âmbito do projeto gráfico, o raciocínio lógico da composição manual, em contraponto à digital, depende intrinsecamente desses fatores para o alcance da impressão e isso se relaciona diretamente com aquele que compõe, que maneja e arquiteta o projeto gráfico.

Esse conjunto de ideias e contraponto de questões será devidamente aprofundado nos capítulos que se destinam à investigação dos processos linguísticos recorrentes ao trabalho de Aloisio Magalhães e Eugene Feldman. Aqui nos reservamos a apenas apontar as referências teóricas e técnicas de tal estudo, pois elas são viabilizadoras de uma análise que integra tanto a técnica como, principalmente, a linguagem gráfica. 


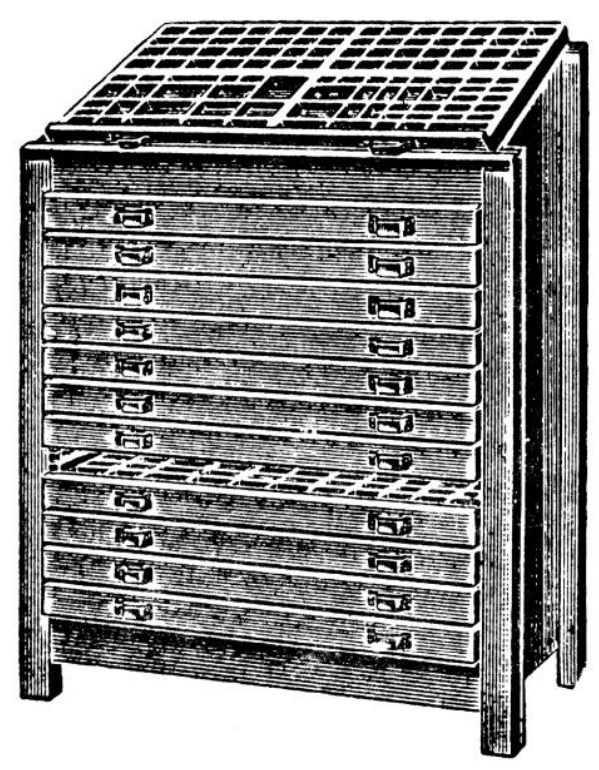

Ilustr. (15) Gaveteiro de tipos - cavalete

Fonte: Apostila OTSP, 2010

Especificaremos agora a classificação do chamado "material branco" a fim de melhor compreendermos seu uso e, por consequência, a lógica do sistema ao qual pertence.

Como vimos, o material branco é empregado na montagem das composições para separar letras, palavras e linhas. Serve também para justificar (blocar) linhas em uma medida pré-determinada. Sua altura - 54 pontos ou $20,3 \mathrm{~mm}$ - é menor do que a do tipo e, portanto, não recebe tinta durante o processo de impressão. São utilizados nesse processo os seguintes materiais: espaços, quadrados, entrelinhas, lingotes e lingões (ou guarnições).

- Espaços são confeccionados nos corpos 6, 8, 10, 12, 14, 16, 18 e 20, com espessuras adequadas a cada corpo. Servem para separar letras, palavras e justificar linhas. 
- Quadratins são sempre iguais ao corpo do tipo. Por exemplo, o quadratim do corpo 12 tem 12 pontos de espessura. O meio quadratim tem a metade da espessura do quadratim e também é conhecido como espaço natural. Sua espessura contém proporção que se adéqua à separação de palavras por ser justamente a metade do valor do corpo de tipo. Espaços auxiliares são utilizados como recurso de justificação, por apresentarem espessuras mínimas.

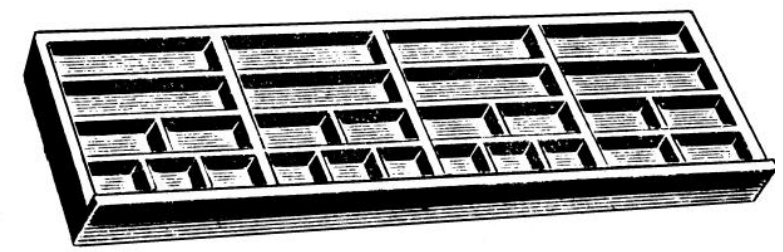

Ilustr. (16) Caixa de espaços

Fonte: Apostila OTSP, 2010

MATERIAL BRANCO

ESPAÇOS

Altura 54 pontos $=1$ furo +6 pontos $=20,3 \mathrm{~mm}$

\begin{tabular}{|c|c|c|c|c|c|c|c|c|}
\hline \multicolumn{2}{|c|}{6} & \multicolumn{2}{c|}{8} & \multicolumn{2}{c|}{10} & \multicolumn{3}{c|}{12} \\
\hline \multicolumn{2}{|c|}{3} & \multicolumn{2}{|c|}{4} & \multicolumn{3}{c|}{5} & \multicolumn{3}{c|}{6} \\
\hline \multicolumn{2}{|c|}{2} & 2 & 3 & 2 & 3 & 3 & 4 \\
\hline 1 & $11 / 2$ & 1 & $11 / 2$ & 1 & $11 / 2$ & 1 & $1 \frac{1}{2}$ & 2 \\
\hline
\end{tabular}

\begin{tabular}{|c|c|c|c|c|c|c|c|c|c|c|c|}
\hline \multicolumn{3}{|c|}{20} & \multicolumn{3}{c|}{18} & \multicolumn{3}{c|}{16} & \multicolumn{3}{|c|}{8} \\
\hline \multicolumn{3}{|c|}{10} & \multicolumn{3}{c|}{9} & \multicolumn{3}{|c|}{8} & \multicolumn{3}{|c|}{} \\
\hline 3 & 4 & 6 & 3 & 4 & 6 & 3 & 4 & 6 & & & \\
\hline 1 & $11 / 2$ & 2 & 1 & $11 / 2$ & 2 & 1 & $11 / 2$ & 2 & & & \\
\hline
\end{tabular}

Ilustr. (17) Quadro esquemático da caixa de espaços

Fonte: Apostila Senai, 1970 


\begin{tabular}{|c|c|c|c|c|c|c|c|c|c|c|c|c|c|c|c|c|}
\hline & 20 & 18 & 16 & 14 & 12 & 10 & 9 & 8 & 7 & 6 & 5 & 4 & 3 & 2 & $11 / 2$ & 1 \\
\hline 20 & $\square$ & & & & & U & & & & | & | & I & I & 1 & 1 & | \\
\hline 18 & & $\square$ & & & & & I & & & 】 & & I & I & I & I & 1 \\
\hline 16 & & & $\square$ & & & & & 【 & & 【 & & I & I & I & I & 1 \\
\hline 14 & & & & $\square$ & & & & & 【 & 【 & & I & I & I & I & 1 \\
\hline 12 & & & & & च & & & & & I & & I & I & I & I & 1 \\
\hline 10 & & & & & & घ & & & & & I & & I & I & 1 & 1 \\
\hline 8 & & & & & & & & - & & & & I & I & I & I & 1 \\
\hline 6 & & & & & & & & & & - & & & ' & I & I & ' \\
\hline
\end{tabular}

Ilustr. (18) Tabela de espaços - quadratins

Fonte: Apostila OTSP, 2010

A tabela apresentada na ilustração (18) demonstra a divisão e progressão dos espaços partindo sempre do quadratim. Sua leitura deve ser feita seguindo a linha da esquerda para a direita de modo a encontrar as espessuras dos espaços (cabeçário da tabela) de acordo com o valor de corpo do quadratim (coluna à esquerda). Exemplo: o quadratim corpo 20, possui as seguintes espessuras: $20 \times 10$ (espaço natural); $20 \times 6 ; 20 \times 5 ; 20 \times 4 ; 20 \times 3 ; 20 \times 2 ; 20 \times 1 \frac{1}{1} 2 ; 20 \times 1$. O quadratim corpo 18 terá, portanto, a seguinte divisão de espessuras (note-se que em valores decrescentes): $18 \times 18 ; 18 \times 9$ (espaço natural); $18 \times 6 ; 18 \times 4 ; 18 \times 3 ; 18 \times 2 ; 18 \times 1$ $1 / 2 ; 18 \times 1$.

As entrelinhas servem para separar linhas de texto. As espessuras das entrelinhas são de 1, 2, 3 e 4 pontos e os comprimentos são de 2, 3, 4, 5 e 6 furos. 


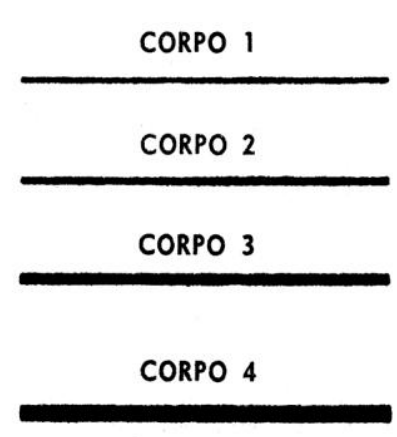

Ilustr. (19) Tabela de entrelinhas

Fonte: apostila Senai
2 furos

3 furos

4 furos

5 furos

6 furos

- Lingotes são barras de liga tipográfica que possuem a mesma função das entrelinhas, porém numa medida maior, na espessura 6 e 12 pontos e os comprimentos também são de 2, 3, 4, 5 e 6 furos.

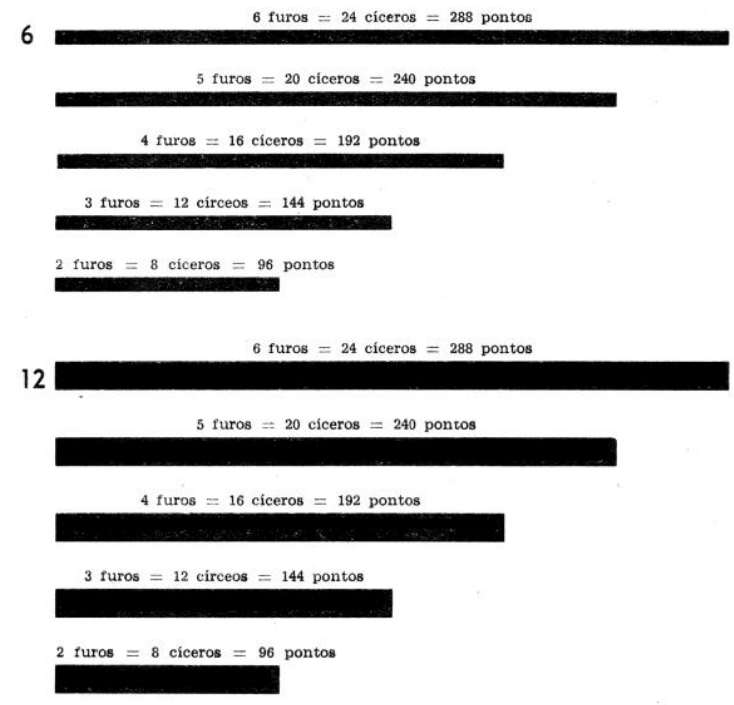

Ilustr. (20) Lingotes

Fonte: Apostila Senai, 1970 
- Os quadrados são utilizados para justificar composições, tanto na horizontal quanto na vertical. Existem três medidas de quadrados: 24, 36 e 48 pontos, nas seguintes espessuras: 1, 2, 3, 4, 6, 8, 10, 12, 14, 16, 18, $20,24,36$ e 48 pontos.

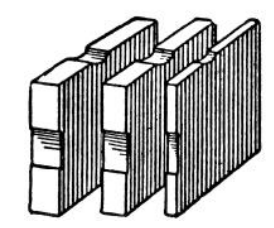

Ilustr. (21) Quadrados

Fonte: Apostila OTSP, 2010
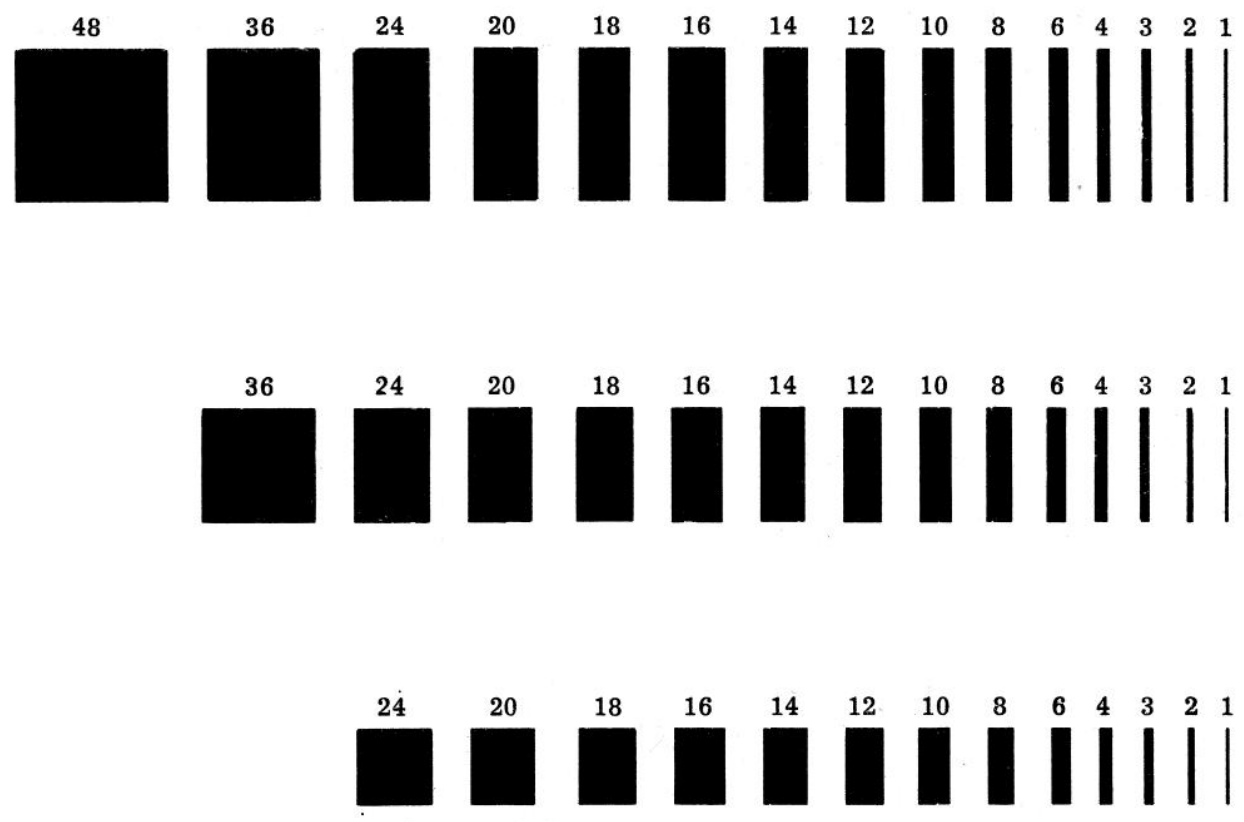

Ilustr. (22) Quadrados

Fonte: Apostila OTSP, 2010 
- Os lingões, assim como os lingotes e as entrelinhas, são materiais que têm como função espacejar e justificar composições, porém em uma medida maior. São encontrados nas espessuras de 24, 36 e 48 pontos. Os comprimentos são de 2, 3, 4, 5 e 6 furos.

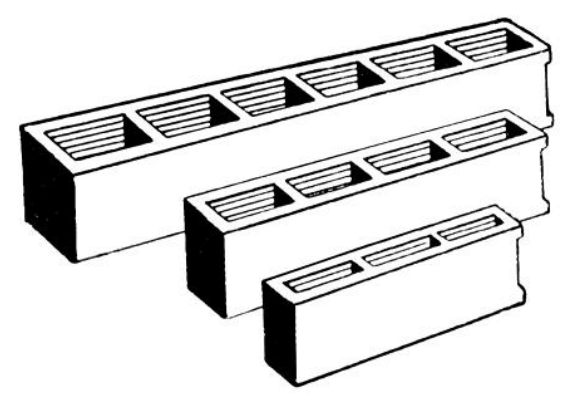

Ilustr. (23) Lingões

Fonte: Apostila OTSP, 2010

As guarnições são confeccionadas em ferro fundido e são utilizadas na fixação de formas tipográficas nas ramas. São encontradas nos comprimentos de 2, 3, 4, 5, 6, 8, 10, 12 e 15 furos e nas espessuras de 2, 3, 4, 6, 8, 10 e 12 cíceros.

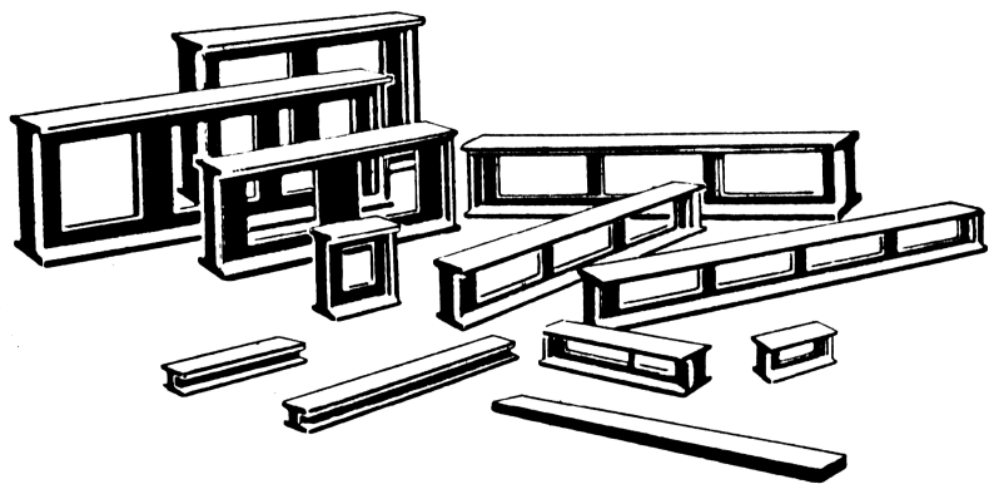

Ilustr. (24) Guarnições

Fonte: Apostila OTSP, 2010 
Cabe ainda especificar que as referências encontradas no sistema de composição manual, conjuntamente com o sistema de impressão direto ${ }^{10} \mathrm{em}$ tipografia, irão estabelecer as particularidades a serem investigadas na análise do trabalho gráfico de Aloisio Magalhães. Além deste sistema, veremos que Aloisio contava com um repertório amplo de técnicas impressão de gravura como a litografia, clichê de metal, xilogravura, clichê de barbante e pochoir. Tais técnicas davam vazão à criação de suas ilustrações e dialogavam em uma constante proposta experimental de linguagem gráfica articulada assim por ele.

Às técnicas de impressão de gravura soma-se o contato de Aloisio com o sistema de impressão em offset que possui, enquanto principal característica, a impressão indireta. Ou seja, a imagem concebida é gravada em uma chapa de alumínio pré-sensibilizada e fixada em um cilindro na impressora. Essa, por sua vez, recebe tinta e a imagem é transferida para outro cilindro de borracha, obedecendo às mesmas leis físico-químicas que regem a litografia - áreas lipófilas, que atraem gordura e ali formam os grafismos e áreas hidrófilas que, molhadas, repelem gordura nas áreas de contra grafismo. Por fim, a imagem é repassada ao papel pelo contato deste último cilindro de borracha que contém gravada a imagem.

Aloisio Magalhães, em sua experiência n’O Gráfico Amador, já havia realizado trabalhos com offset em algumas raras publicações, mas é no encontro com Eugene Feldman na The Falcon Press - Filadélfia, que ele tem um melhor contato com esse tipo de tecnologia de impressão e também a oportunidade de explorá-lo, no sentido experimental, como será detalhado no quarto capítulo deste estudo.

\footnotetext{
${ }^{10}$ Denomina-se sistema direto de impressão quando a transmissão da imagem é realizada diretamente da matriz entintada para o suporte a ser impresso, como é o caso da técnica da xilografia, litografia, gravura em metal, tipografia, dentre os principais processos de impressão. Este sistema de impressão em tipografia nos Estados Unidos e Europa é conhecido pelo termo letterpress. Ao contrário deste, o offset, representa o sistema indireto de impressão, pelo fato da imagem gravada na chapa de alumínio em seu cilindro ser transmitida primeiramente ao cilindro de borracha e este por último retransmiti-la ao papel.
} 


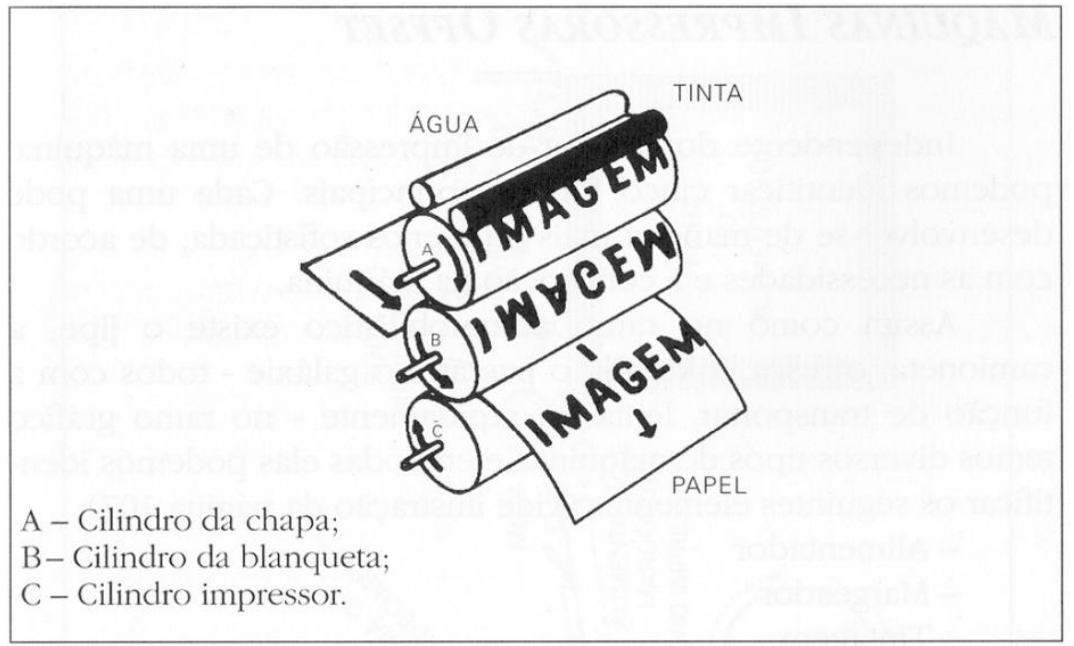

Ilustr. (25) Sistema Offset

Fonte: Mário Carramillo Neto, 1997

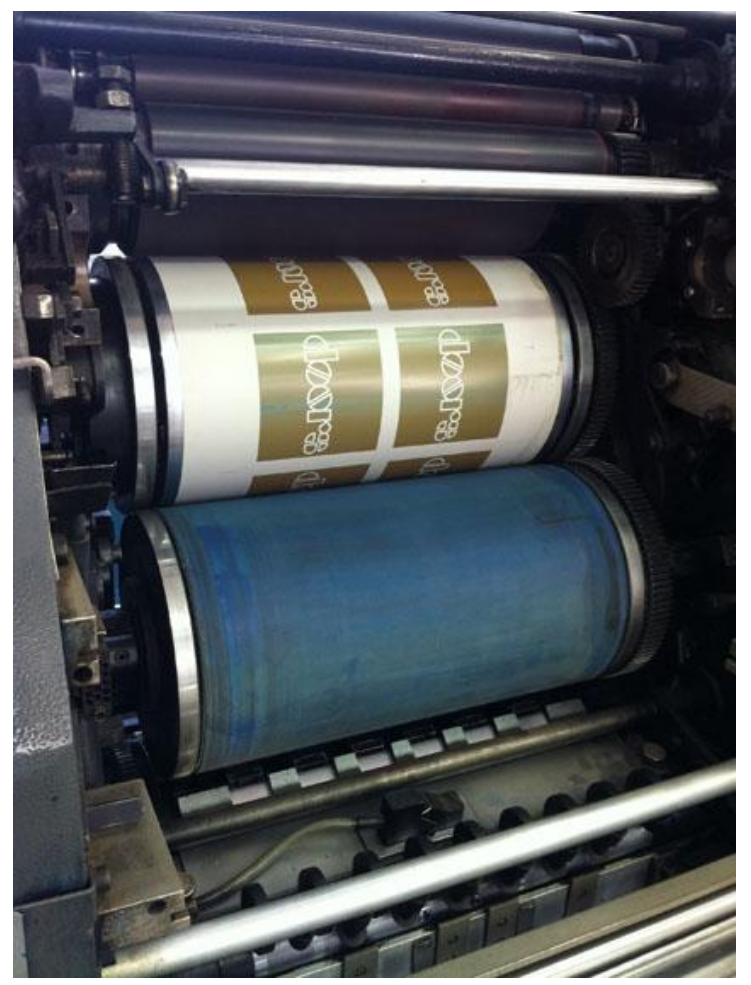

Ilustr. (26) Impressora Offset

Fonte: Escola Senai Theobaldo de Nigris,

foto de Marcos Corrêa de Mello Felisette 


\section{TIPOGRAFIA: A ARTE DE GRAFAR E ESPAÇAR}

Tipografia é a arte de grafar e espaçar. Tal afirmação baseia-se no fato de que a composição manual utiliza esses dois elementos como fundamento e princípio de seu sistema. Isto é, os tipos móveis, os ornamentos e fios utilizados para o grafismo são tão importantes quanto o conjunto de peças que constitui o chamado "material branco", formador de espaços.

Saber compor na tipografia é justamente saber conjugar esses dois elementos. É saber trabalhar a dualidade dos elementos da linguagem: forma e contra forma, claro e escuro, positivo e negativo, nota e pausa. A composição tipográfica, enquanto estrutura física, depende da ordenação desses elementos, pois só assim a fôrma tipográfica é possibilitada de manejo para a impressão. Posto isso, compreendemos que saber compor, para os tipógrafos de ofício, é resolver tanto uma questão de ordem física (construção da fôrma tipográfica) quanto estética. Basta lembrarmos que "espaço" na composição manual é matéria física, como já apontado.

No âmbito da linguagem, a construção tipográfica representa a ordenação de seus elementos, segundo a lógica de seu sistema. Ou seja, a possibilidade combinatória de suas peças espelha sua ordem de medida e valores que, por consequência, obedece a uma ordem de escalas partindo-se do quadratim ${ }^{11}$, como vimos nas páginas iniciais deste capítulo.

O sistema tipográfico, desde seu início, no século $\mathrm{XV}$, evoluiu muito rapidamente. Isso se deu por dois fatores: primeiro, a expansão das oficinas pela

\footnotetext{
${ }^{11}$ Quadratins são espaços sempre iguais ao corpo do tipo. Por exemplo, o quadratim do corpo 12 tem 12 pontos de espessura. O meio quadratim tem a metade da espessura do quadratim e também é conhecido como espaço natural. A tabela completa da progressão de valores encontrada no material denominado espaço encontra-se exemplificada no início deste capítulo.
} 
Europa em um ritmo vertiginoso, aliado, obviamente, ao contexto e oportunidade editorial com o advento da imprensa. Em segundo, consequentemente, pela necessidade de uma padronização frente à diversificação de medidas e formulações adotadas pelos tipógrafos.

Nesse sentido, grandes mestres como Didot (1730- 1804) irão alcançar, como veremos, uma formulação teórica mais completa a partir das tentativas de sistematização propostas por outros tipógrafos contemporâneos, como Martín Domingo Fertel, editor e tipógrafo francês. Vale lembrar que o aperfeiçoamento do sistema tipográfico não só idealizou a racionalização de tais medidas para sua prática como, também, e fundamentalmente, para a fabricação de suas peças. Ou seja, a fundição dos tipos e demais materiais tipográficos.

A história da tipografia conjugada à história do livro impresso nos mostra que, a princípio, os fundidores fabricavam os tipos de acordo com o trabalho a ser impresso. Desse modo, se adequava ao estilo da obra, medidas de altura e espessura convenientes para os tipos móveis. Basta lembrar da grande variação de matrizes do mesmo caractere utilizadas por Gutenberg na impressão e publicação da Bíblia de 42 linhas em Mainz, no ano de 1455.

É claro que as razões desse fato foram outras em sua época, tendo em vista a questão da simulação da forma manuscrita à impressa, com o objetivo de aproximar a textura manual à mecânica. Por isso a variação. Mesmo assim, pode-se verificar que do ponto de vista da fabricação do material tipográfico, suas medidas e, por consequência, a conjugação destes ao projeto editorial, era prática comum. 


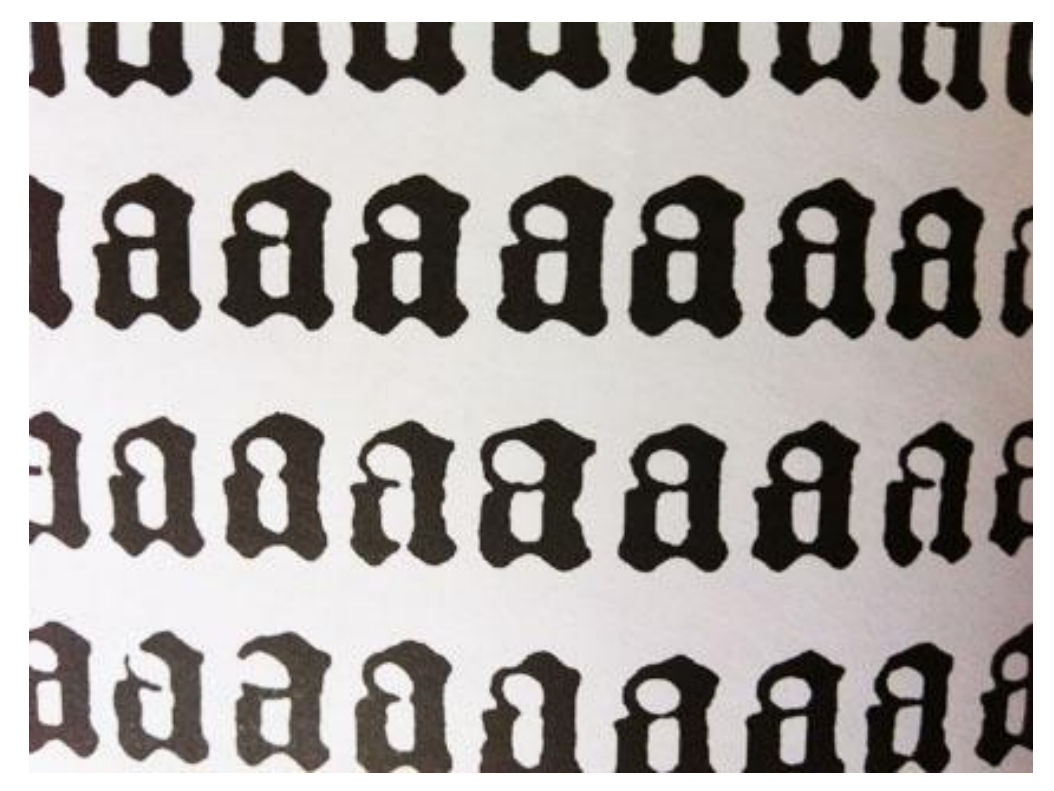

llustr. (27) Variação de matrizes de um mesmo caractere.

Bíblia de 42 linhas, Gutenberg, 1455.

Fonte: ROCHA, 2002, p. 28

A história da imprensa nos relata que o primeiro esboço de uma base sistemática para a fundição de tipos móveis foi idealizada pelo tipógrafo e livreiro francês, Martín Domingo Fertel, nascido em Sant-Omer em 1672. Seu manual tipográfico, o primeiro sobre tipografia, foi impresso em 1723 cujo título era La Science Practique de L'imprimerie contenant des Instructions tré faciles pour se Perfeccionner dans cet art. Essa obra com 292 páginas no formato in-quarto ${ }^{12}$ contêm as linhas teóricas propostas por Fertel e ainda um primeiro modelo de tipômetro ${ }^{13}$.

Podemos observar um pouco mais adiante nesta cronologia, que Pierre Simon Fournier (1712-1768), tido na história da tipografia como um dos melhores

\footnotetext{
$12 \mathrm{O}$ termo formato in-fólio indica que a folha está dobrada em sua metade longitudinal. Na medida decimal, os livros in-fólio correspondem, aproximadamente, ao formato $20 \times 30 \mathrm{~cm}$. Os livros in-quarto têm as dobras de suas folhas em duas metades, ou em cruz. Seu formato indica, aproximadamente, $15 \times 20 \mathrm{~cm}$ de altura. (SATUÉ, 2004, pg. 139)

${ }^{13}$ Espécie de régua com a escala de medidas tipográficas.
} 
puncionistas $^{14}$ e fundidores do século XVIII, publicou, em 1737, um sistema conhecido como "tábua das proporções para a fundição sistemática dos caracteres". Para tanto, partiu da medida encontrada no menor corpo de letra utilizado comumente, a nomparela ${ }^{15}$, e a dividiu em seis partes iguais, e a cada destas denominou como ponto. Chegava-se assim à medida duo decimal.

Vale ressaltar, que a tipografia é múltipla ou submúltipla de 12. As séries que encontramos distribuídas tanto nos tipos móveis como no "material branco" provém desta lógica matemática e a variação do tamanho dos corpos dos tipos segue a regra. Desse modo, temos até hoje (e cabe citar a lacuna na compreensão da proveniência de tais medidas no sistema digital) caracteres seguindo esta progressão de valores: $6,8,10,12,14,16,18,20,24,36$ pontos e assim por diante. Também é possível encontramos outra série em progressão (com maior fragmentação): $6,7,8,9,10,11,12,14,16,18,20,24,28,32,36,40,48,60,72$, 84, 96, fundidos à base do ponto tipográfico. Portanto, é nesse princípio que se encontra a gênese do sistema de medida adotado na tipografia.

A partir de tais pressupostos, Fournier começou a fundir, em 1742, todo material tipográfico e a medida de 12 pontos, o dobro da nomparela, foi denominada de "Cícero". Esse padrão de medida tem história curiosa e algumas versões. Uma delas é que Fournier se baseou em uma letra que continha aproximadamente 11 pontos impressa na obra "Epístolas Familiares", de Cicerón, 1469, em Veneza. Partindo dessa versão, concluímos que para adotar uma medida padrão, Fournier buscou uma referência acreditando ser essa a mais conveniente entre a proporção de corpo, letra impressa e leitura, aplicada em uma obra.

\footnotetext{
${ }^{14}$ Puncionista é o artesão que grava a punção (matriz do desenho do caractere) para ser fundida.

${ }^{15}$ Medida tipográfica adotada na França, entre os séculos XVII e XVIII.
} 
Vimos ainda, no decorrer da história da imprensa, que o sistema proposto por Fournier fora publicado em seu "Manualle Tipographique" e era mais completo em relação ao de Fertel, pois, como vimos, estabelecia como mínima a medida que mais tarde denominou como ponto (equivalente a 1/72 da polegada). O ponto de Fournier convertido ao sistema métrico, equivalia a $0,350 \mathrm{~mm}$ e foi aperfeiçoado pela sua constante aplicação.

Foi em 1760, que François-Ambroise Didot (1730-1804), famoso gravador da família Didot, aperfeiçoou a medida de Fournier e chegou à medida de um ponto que satisfazia mais as relações entre os materiais tipográficos: o ponto Didot, também conhecido como ponto francês (convertido para a escala métrica, equivale cerca de 0, $376 \mathrm{~mm})$.

Para alcançar esse padrão de medida e aprimorar o sistema de Fournier, Didot tomou como referência a medida "pé de rei" usualmente utilizada na época. Como exemplo, observamos o pequeno quadro comparativo a seguir:

Tabela (2) Quadro de medidas tipográficas

\begin{tabular}{l|l}
\hline Pé de rei & 12 polegadas \\
\hline Polegada & 12 linhas \\
\hline Linha & 12 pontos \\
\hline
\end{tabular}

Fonte: Marcos Corrêa de Mello Felisette

Didot ainda acharia excessivamente fino um ponto derivado da medida "pé de rei" o que não possibilitaria, deste modo, formar uma graduação adequada de caracteres. Adotou, por consequência, uma unidade de dois pontos ("pé de rei") para formar o que conhecemos como ponto no sistema Didot. 
No Brasil, como já foi apontado, o sistema Didot foi e ainda é o mais empregado. Isto se deve provavelmente à influência da cultura francesa em nosso país e por razões de proximidade entre as línguas maternas (latim). Podemos retomar como exemplo o uso no Brasil da chamada caixa-francesa (gaveta cuja divisão de caracteres obedece à disposição francesa). Ainda em relação ao sistema Didot e seu emprego nas tipografias brasileiras, cabe retomar uma terceira padronização cujo emprego é exclusivo ao Brasil: o furo (medida equivalente a 4 Cíceros ou 48 pontos).

O ponto Fournier (aproximadamente $0,350 \mathrm{~mm}$ ), ainda utilizado em sua dimensão original na Bélgica, teve seu aperfeiçoamento na Inglaterra e, por consequência, foi empregado em sua colônia, Estados Unidos. Passou a ser reconhecido como medida Anglo Americana cujo valor é de $0,351 \mathrm{~mm}$ e a somatória de seus doze pontos, recebeu o nome de "paica".

Tal medida foi muito difundida nos Estados Unidos no século XX, devido aos avanços tecnológicos deste país, em particular a fotocomposição e mais tarde, como veremos, a computação gráfica. Nesse sentido, o ponto tipográfico teve também sua adaptação à tela do computador, mas não nos compete, neste momento, retomar tal assunto.

Tabela (3) Quadro de evolução das medidas tipográficas

\begin{tabular}{l|l|l}
\hline Sistema & Ponto & Altura do tipo \\
\hline Fournier & $0,350 \mathrm{~mm}$ & $22,050 \mathrm{~mm}$ \\
\hline Anglo Americano & $0,351 \mathrm{~mm}$ & $23,317 \mathrm{~mm}$ \\
\hline Didot & $0,376 \mathrm{~mm}$ & $23,566 \mathrm{~mm}$ \\
\hline
\end{tabular}

Fonte: Marcos Corrêa de Mello Felisette 
Como vimos, então, a história da tipografia é capaz de revelar particularidades de sua técnica, da evolução de sua linguagem e, por conseguinte, da história da página impressa. Realizaremos, portanto, uma investigação acerca do sistema tipográfico e suas implicações ao campo editorial. Para tanto, a pesquisa se apoiará na técnica e linguagem tipográfica para explorarmos sua relação (do ponto de vista projetivo - construtivo), com o livro impresso.

Nesse sentido, a dissertação quanto ao sistema tipográfico nada mais é do que a tentativa de elucidar a singularidade de uma técnica e sua lógica: as implicações junto a seus agentes e de como estes por fim, interagem, pensam e constroem linguagem.

Esse percurso, como nos descreve a história da imprensa, acima de tudo obedeceu ao seu fim, ou seja: o livro impresso, sua formatação e, por conseguinte, a estreita relação entre o formato de página e mancha de texto. Não é à toa, portanto, que a arte tipográfica é chamada de arte negra e isso não se deve apenas à tinta, obviamente, e sim pelo que foi apontado no início deste parágrafo.

Mesmo após a transposição do livro manuscrito para o livro impresso, artesãos do livro sempre tiveram em mente o princípio de composição de texto sob a perspectiva da construção da imagem e de sua relação com o espaço. Mais do que isso, imagem para ser vista, lida e sentida. Robert Bringhurst (2005, p. 32) em seu livro Elementos do Estilo Tipográfico, cita uma antiga metáfora para exemplificar o sentido de construção do texto pelo tipógrafo:

[...] se o pensamento é um fio de linha, o narrador é um fiandeiro mas o verdadeiro contador de histórias, o poeta, é um tecelão. Essa velha abstração, própria das narrativas faladas, foi transformada em um fato novo e visível pelos escribas. Após longa prática, seu trabalho ganhou uma textura tão homogênea e flexível que a 
página escrita passou a ser chamada de textus (tecido em latim). $\mathrm{O}$ instrumento tipográfico, seja ele um computador ou uma régua de composição, funciona como um tear. E o tipógrafo, assim como o escriba, procura tecer 0 texto da maneira mais homogênea possivel.

Cor para os tipógrafos não se refere propriamente à variação de tinta (amarelo, vermelho ou azul) e sim a densidade que a textura concentra na composição e isso demanda da massa dos tipos. É comum encontrarmos famílias tipográficas seguindo tal referência e nomenclatura, como por exemplo: Grotesca clara, escura, meia clara, etc.

O tipógrafo, por assim dizer, tem como objetivo na sua composição, tecer o texto, de modo que a sua cor seja a mais homogênea possível, satisfazendo as premissas da legibilidade e adequação ao formato de página. Segundo Bringhurst (2005, p. 32) "[...] a homogeneidade da cor é o objetivo mais comum almejado pelo tipógrafo. $\mathrm{E}$ isso depende de quatro fatores: o desenho do tipo, o espacejamento das letras, das palavras e das linhas. Nenhum é independente do outro.".

Tal afirmação converge com as ideias de Jan Tschichold, que entende como principal tarefa do tipógrafo, na composição, a coordenação dos elementos e seu conjunto. Logicamente, o conceito se refere não somente à composição em si, mas ao projeto editorial e sua criação tipográfica. Criar o todo a partir de partes fragmentadas é o que fundamenta o sistema de composição. Segundo Tschichold em sua obra A Forma do Livro - Ensaios sobre Tipografia e Estética do Livro:

Tipografia sem mácula é certamente a mais frágil de todas as artes. Criar um todo a partir de muitas partes petrificadas, desconexas e determinadas, fazer com que esse todo pareça vivo e consistente - 
só a escultura em pedra se aproxima da inflexível rigidez da tipografia perfeita. (TSCHICHOLD, 2007, p. 29)

Conjunto e fragmentação pertencem ao léxico tipográfico e foi na intenção de fragmentar o que chamamos de matriz rígida - como, por exemplo, uma matriz de xilogravura - que se deu tal invento.

Assim, o sistema tipográfico pode ser comparado à estrutura de linguagem musical no que tange às possibilidades combinatórias e de ordenação de seus elementos. Ou seja, em uma análise comparativa, partindo-se do elemento único (nota musical), encontramos a seguinte progressão a formar o conjunto a seguir:

\begin{tabular}{l}
\hline Nota \\
\hline Espaço entre notas (intervalo, medido em tons) \\
\hline Empilhamento de intervalos (acordes) \\
\hline Progressão dos acordes (campo harmônico) \\
\hline
\end{tabular}

Comparativamente à estrutura musical, vemos no estudo tipográfico a relação que se dá entre os elementos: letra - palavra - mancha de texto - formato de página - livro, como mostra a figura, a seguir, da composição manual: 


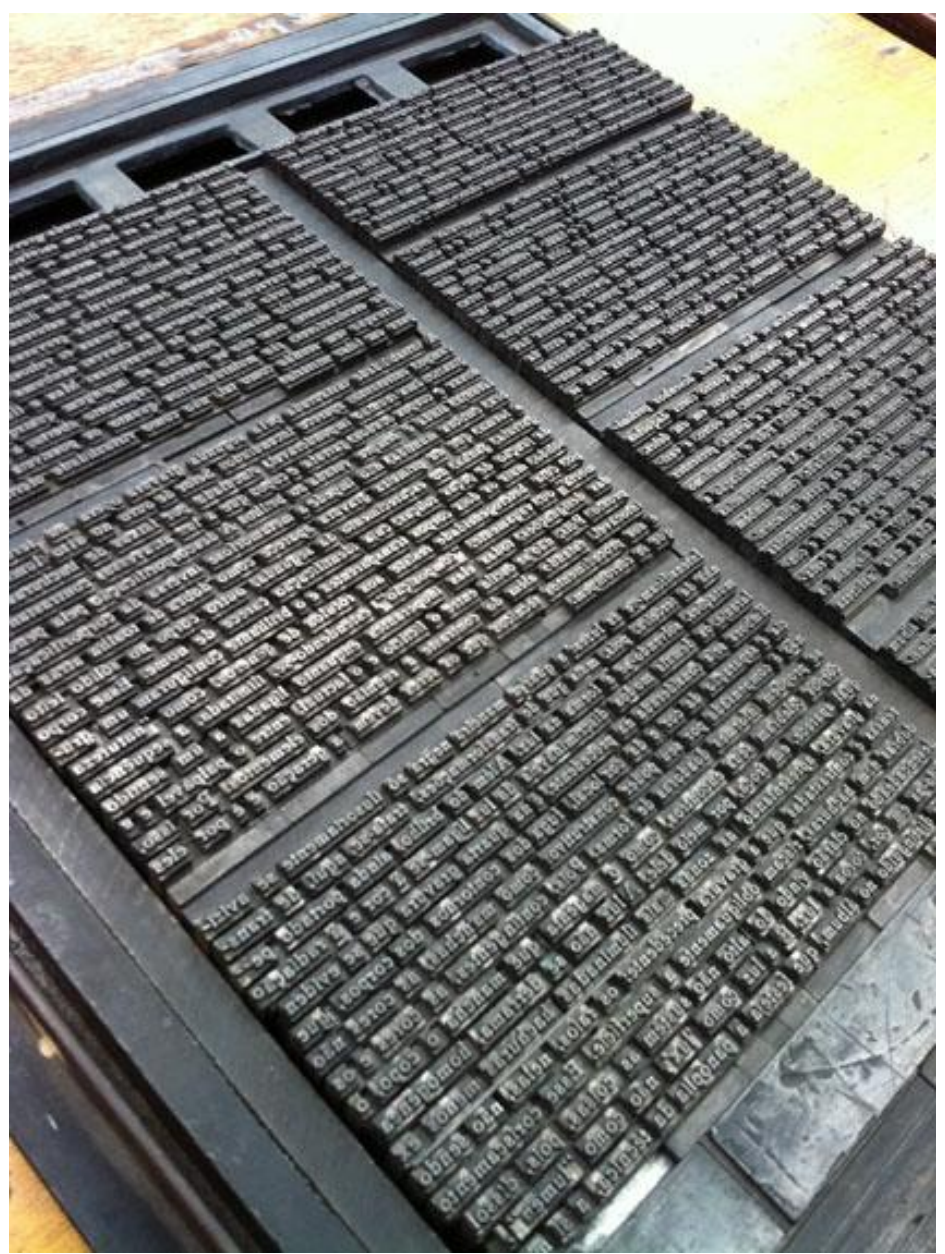

llustr. (28) Fôrma tipográfica.

Fonte: Oficina Tipográfica São Paulo

Foto: Marcos Corrêa de Mello Felisette

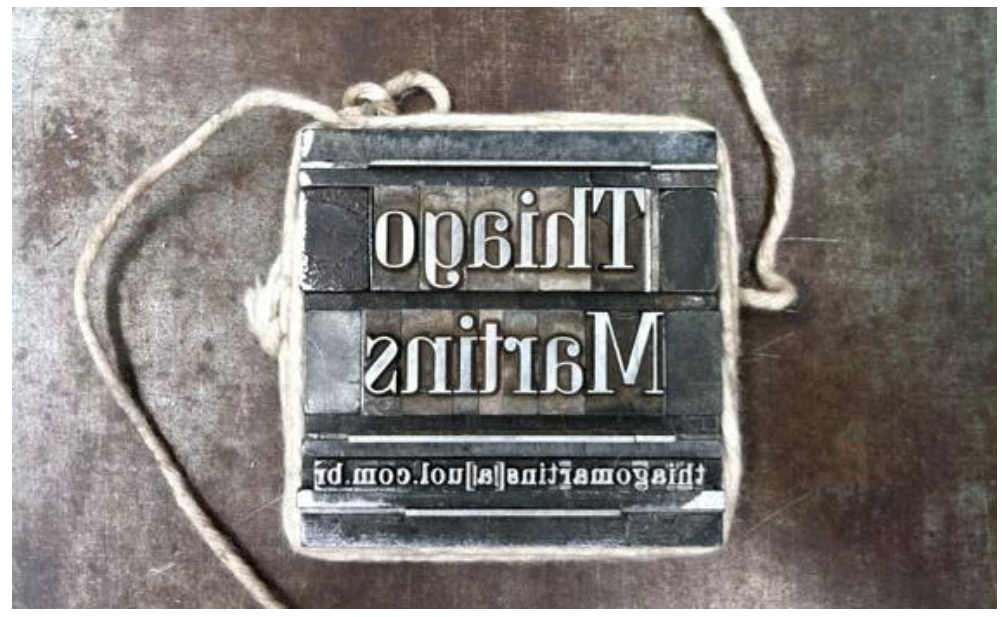

Ilustr. (29) Fôrma tipográfica.

Fonte: Oficina Tipográfica São Paulo

Foto: Marcos Corrêa de Mello Felisette 
Para exemplificarmos essa ideia, partimos da escala maior e consequentemente a formação dos acordes, como aponta o quadro a seguir:

escala maior de dó
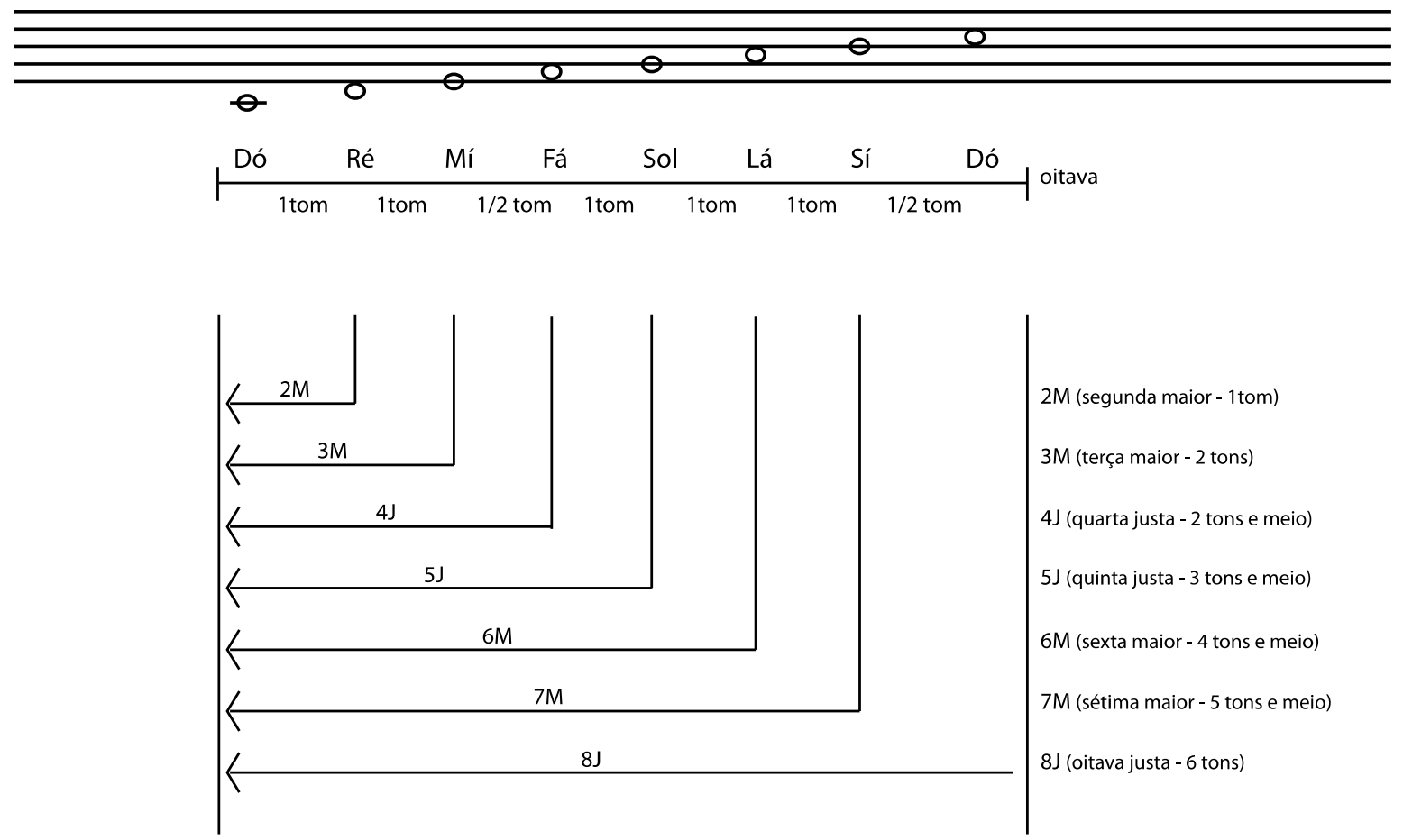

Ilustr. (30) Escala maior de dó

Fonte: Marcos Corrêa de Mello Felisette

Vemos que a escala maior é formada por uma progressão de notas e que a distância entre ambas denomina-se de intervalo. Esse último é medido por tons e assim, na escala maior, temos a seguinte configuração: de Dó para Ré, um tom; de Dó para Mi, dois tons; de Dó para Fá, dois tons e meio; de Dó para Sol, três tons e meio; de Dó para Lá, quatro tons e meio; de Dó para Si, cinco tons e meio e de Dó para Dó completando uma oitava, temos seis tons.

Os intervalos também podem ser vistos, segundo a escala maior, entre duas notas não necessariamente na progressão descrita, como por exemplo, a distância 
entre a nota Ré e a nota Mi é de um tom e a distância entre a nota Mi e Fá é de meio tom. Vimos portanto que a distância entre as notas é medida por tons e de acordo com sua progressão formam-se as escalas.

Aqui reservamo-nos a exemplificar a teoria musical de forma resumida, tendo em vista que a citação da mesma destina-se apenas a criar relações com o sistema tipográfico e elucidar a composição manual e sua linguagem de modo análogo a primeira.

E o que seriam os acordes? De acordo com o quadro descritivo, podemos observar que os acordes formam-se pelo "empilhamento" de intervalos (terças maiores ou menores) e que assumem diferenças de valores (maiores, menores, justos, diminutos, meio-diminutos) dependendo do agrupamento destes mesmos intervalos. Como por exemplo, o acorde de Dó maior com sétima (menor) que se configura pelos seguintes intervalos: Tônica - nota Dó; terça maior - Mi (2 tons); quinta justa - Sol (3 tons e meio) e sétima maior - Si b (5 tons).

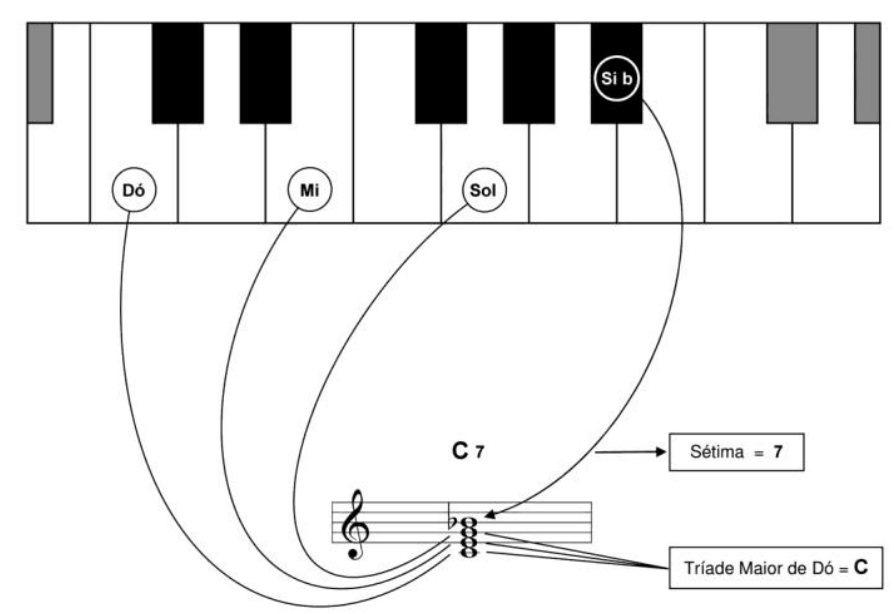

llustr. (30a) Acorde de dó com sétima

Fonte: Maria Lucia Cruz Suzigan 


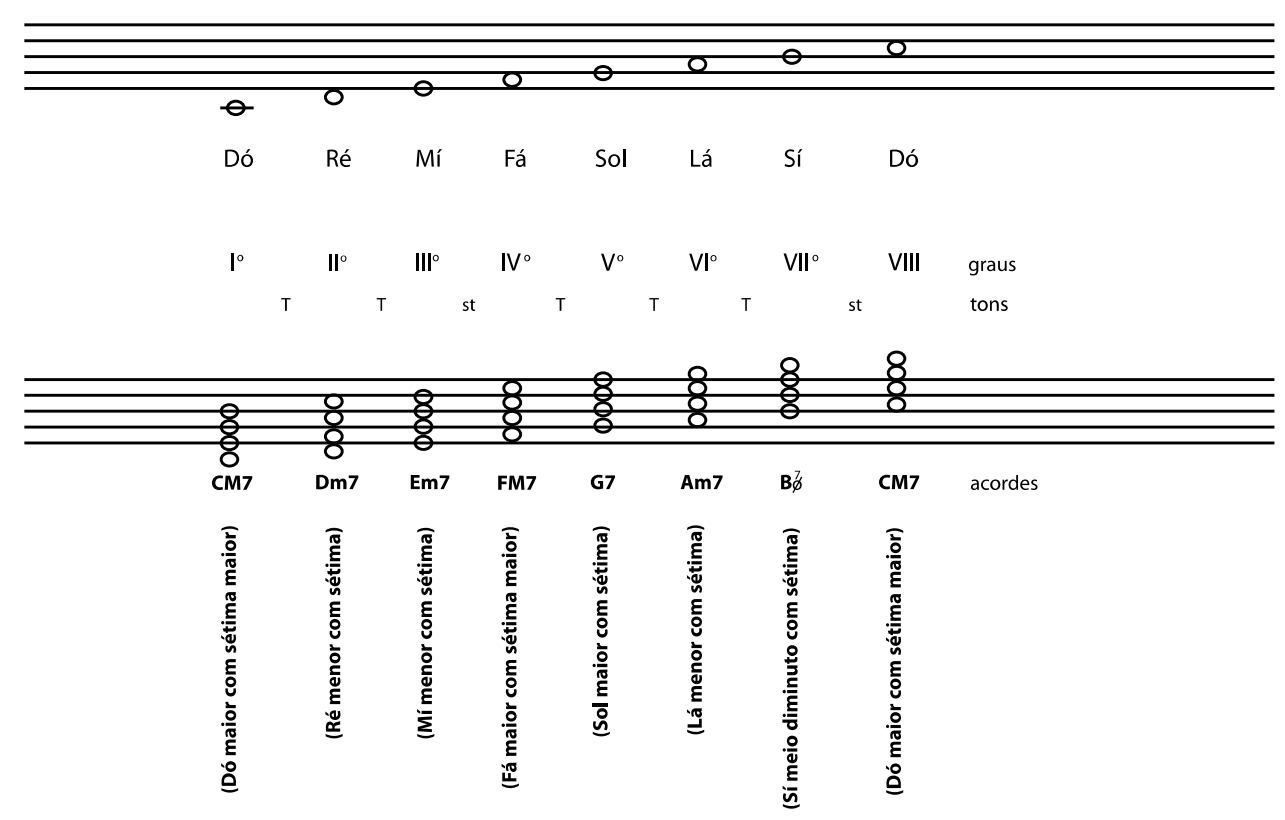

llustr. (30b) Dó maior com sétima (menor)

Fonte: Maria Lucia Cruz Suzigan

Portanto, a partir da escala maior de Dó, origina-se a formação dos acordes com seus respectivos graus (distintos em suas características estruturais e de valor) e consequentemente vemos a delineação do campo harmônico. Deste modo e, portanto, diferentes encadeamentos de acordes, irão provocar diferentes progressões harmônicas. É claro que nesta resumida explanação teórica acerca da teoria musical, a intenção é de que possamos compreender os princípios que regem a estrutura musical para que o estudo tipográfico, com seu léxico muito próximo ao da música, seja debatido.

Termos como arranjo, composição, ritmo, cadência são muito recorrentes no campo da tipografia, e isso não é por acaso. Como vimos, as escalas musicais muito se aproximam das séries encontradas nos corpos de tipos $(6,8$ 10, 12, 14, 16, 18, 20, 24...), uma forma de progressão que é regida por intervalos. Na música, essa distância se dá por tons, na tipografia ocorre através de pontos. 
Essas progressões em ambos os casos possuem uma lógica e um número infinito de combinações em suas variáveis, trabalham dentro de um sistema de regras e as possibilidades de criação se estabelecem a partir da compreensão destes pressupostos. Deste modo, podemos entender uma composição musical que possui uma melodia e esta melodia parte de uma sequência de acordes que formam um campo harmônico.

Seguindo esse princípio, podemos enxergar a construção de uma página de livro onde o corpo de tipo conjuga-se ao tamanho da linha que por consequência compõe a mancha de texto adequando-se ao formato de página de um projeto editorial.

Parafraseando Ellen Lupton (2006), letras reúnem-se em palavras, palavras compõem sentenças e sentenças formam um texto. Como já fora citado no início deste capítulo, a dinâmica da composição tipográfica se baseia em dois movimentos: o construir e o fragmentar. Todos os elementos de composição em tipografia obedecem a esta lógica e interagem-se desta maneira. Compor em tipografia utilizando-se de tipos e espaços é, antes de mais nada, arquitetar a construção objetivando o conjunto, o todo.

Dois elementos se destacam na composição tipográfica: aquilo que grafa e por outro lado tudo aquilo que espaceja. Compor é saber lidar com estes dois elementos. Mais ainda, na composição manual, espaço é elemento físico e sem ele nada pode ser estruturado. Talvez seja esta a principal lição, no que compete a linguagem tipográfica, que o sistema de composição manual nos deixou como legado. Corrobora com essa afirmação a citação de Ellen Lupton:

O design é tanto um ato de marcar quanto de espaçar. A arte do tipógrafo não lida apenas com a textura positiva das letras, mas com 
os espaços negativos entre elas e ao seu redor. $\mathrm{Na}$ prensa tipográfica, todo espaço é construído por um objeto físico (uma peça de metal ou madeira sem imagens proeminentes). Os lingotes de chumbo e as fatias de cobre inseridos anonimamente entre palavras e letras são tão físicos quanto os caracteres à sua volta. (LUPTON, 2006, p. 67)

Ainda em relação à questão física da linguagem tipográfica, podemos afirmar com toda certeza de que este modo de construção e fixação da palavra foi a principal transformação ocorrida com o texto. De acordo com Walter Ong em sua obra Orality and Literacy: The Technologizing of the Word:

A impressão tipográfica do alfabeto, na qual cada letra era moldada em uma peça isolada de metal (o tipo) foi uma revolução psicológica de primeira ordem [...] a impressão situa as palavras no espaço com uma fixidez que a escrita nunca atingiu. Se a escrita transportou as palavras do mundo do som para o mundo do espaço visual, a impressão fixou sua posição nesse espaço. (ONG apud LUPTON, 2006, p. 67)

Decorrendo desse assunto, propomos um pequeno exercício de visualização e equivalência entre nota/pausa e tipo/espaço, começando por observar a estrutura de uma célula rítmica a partir da seguinte notação de um compasso 4/4:

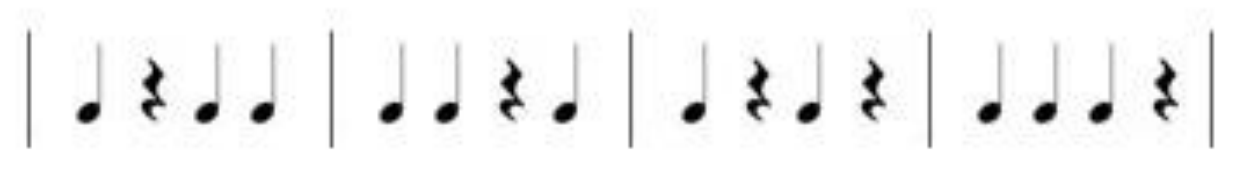


Nesse exemplo, vemos que a linha rítmica se dá a partir da combinação entre nota e pausa e que o desenho sonoro se origina justamente deste planejamento. É claro que também devemos levar em conta outros fatores pertencentes à linguagem rítmica, como as acentuações, tempo forte e fraco.

No entanto, no que se refere a este estudo comparativo, esse exemplo é facilmente transposto ao raciocínio do tipógrafo em seu ofício. Ou seja, o desenho de uma linha se origina tanto dos tipos como também dos espaços que justificam a mesma. Aliás, o termo "justificação" em tipografia se emprega nesse sentido, como podemos verificar na figura abaixo:

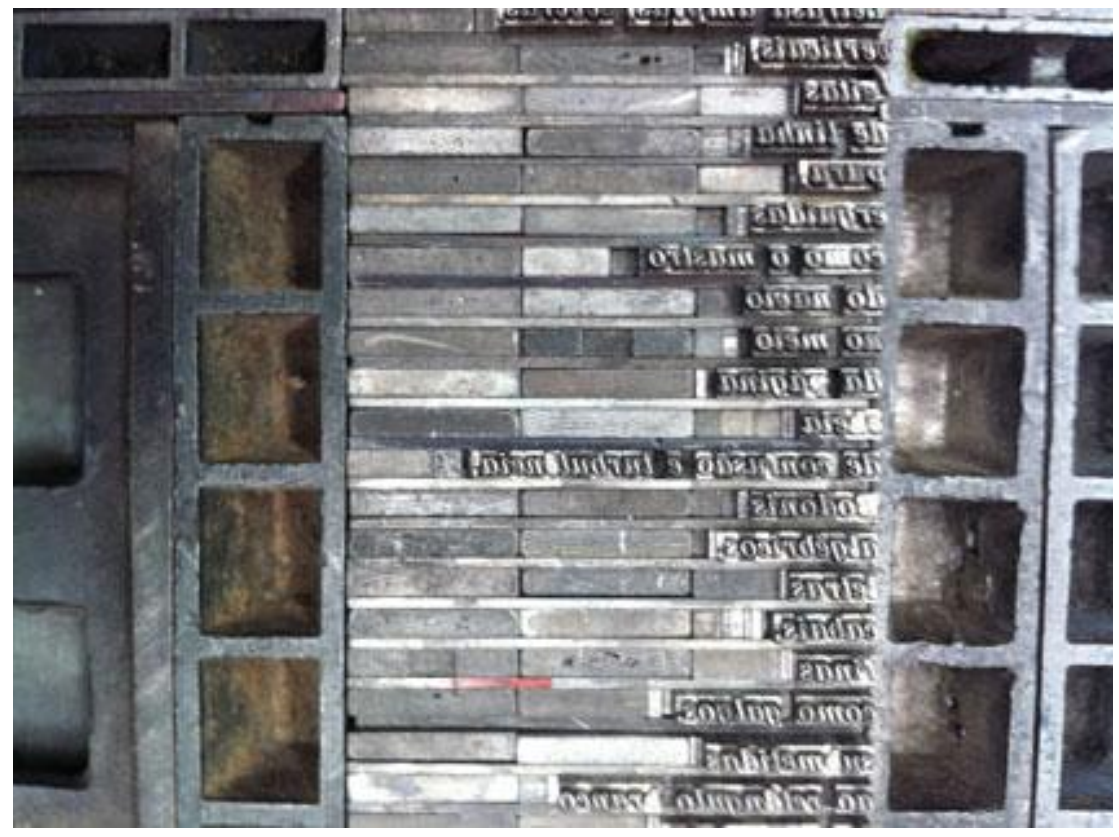

Ilustr. (31) Linhas compostas na fôrma tipográfica.

Fonte: Oficina Tipográfica São Paulo

Foto: Marcos Corrêa de Mello Felisette 
Toda nota possui uma equivalência em pausa. A notação rítmica atribui um valor de tempo para cada nota, bem como possibilita a subdivisão desses mesmos valores para que haja a construção do ritmo. O mesmo podemos verificar com o material tipográfico. Ou seja, todo corpo de uma fonte possui seu espaço equivalente que também pode ser subdividido de modo a ajustar e permitir a composição tipográfica como mostra a figura:
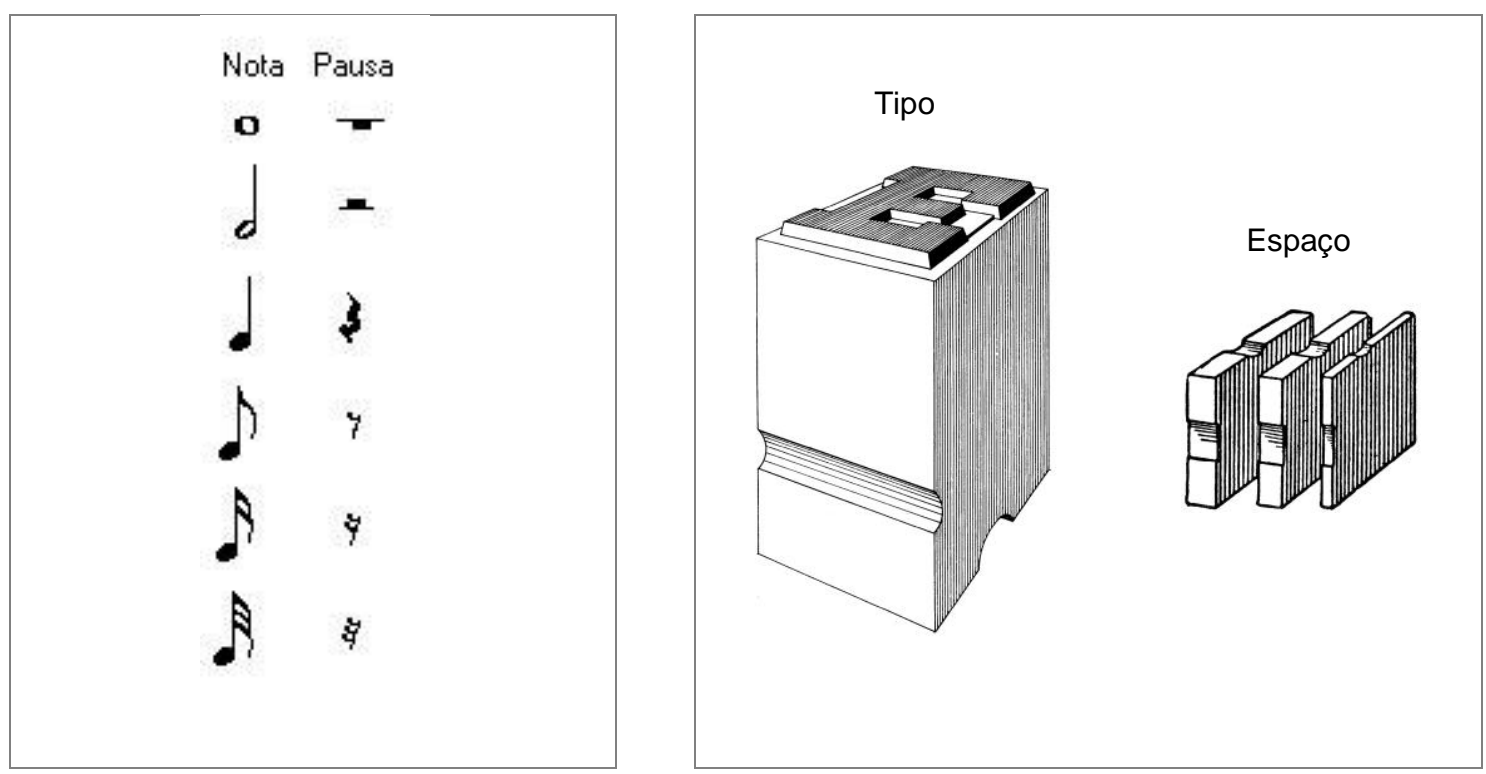

Ilustr. (32) Quadros análogos - comparativo entre notação musical e elementos da composição manual Fonte: Marcos Corrêa de Melo Felisette

Segundo a regra do ofício, a composição é feita linha por linha até que se alcance a construção do conjunto, ou melhor, a fôrma ou chapa tipográfica. O mesmo raciocínio aplica-se à musica, como por exemplo no jazz, onde grupos de compassos são compostos em blocos até formarem um chorus como podemos verificar na figura abaixo: 
Bloco A (8 compassos) + Bloco A (8 compassos) + Bloco B (8 compassos) + Bloco A (8 compassos)
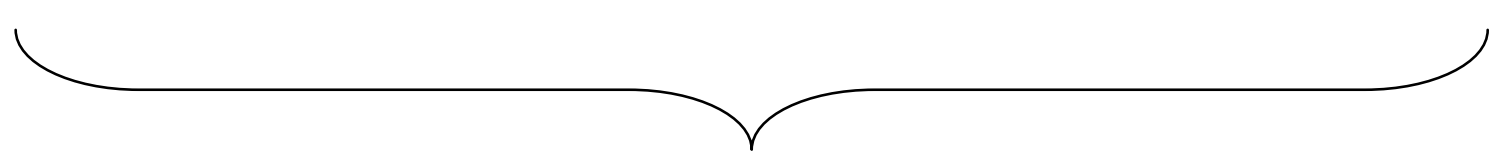

32 compassos $=1$ chorus

Ilustr. (33) Exemplo de composição de um chorus

Fonte: Marcos Corrêa de Melo Felisette

\section{A LINGUAGEM TIPOGRÁFICA}

A habilidade de um tipógrafo reside em dar forma, transpor e adequar um texto manuscrito para um texto composto por tipos. Para tanto, ele deve contar, além de seu conhecimento técnico e sistêmico do conjunto, de seu repertório e sensibilidade para a criação. Compor um texto em tipografia, é trabalhar uma textura, assim como os escribas o faziam com os manuscritos e como os músicos o fazem ao tecer as vozes em uma obra musical. De acordo com Robert Bringhurst:

Dimensionar e espacejar tipos, assim como compor e tocar música ou pintar uma tela, tem muito a ver com intervalos e diferenças. À medida que a textura é construída, relações precisas e discrepâncias mínimas ficam perceptíveis. Estabelecer as dimensões gerais de uma página é em grande parte uma questão de somas e limites. Nesse âmbito, é normalmente suficiente - e melhor - que a harmonia estrutural seja mais implícita que imposta. Essa é uma das razões pelas quais os tipógrafos tendem a se apaixonar por livros. As páginas flexionam-se e viram-se; suas proporções fluem e refluem em relação à forma subjacente. Mas a harmonia dessa forma não é 
menos importante nem mais difícil de perceber que a harmonia das formas das próprias letras (BRINGHURST, 2005, p. 161).

A maior tarefa de um tipógrafo na construção de um livro é dar forma ao seu conteúdo. Nas palavras de Robert Bringhurst: "[...] a tipografia existe para honrar seu conteúdo." (BRINGHURST, 2005, p. 23). Ela deve ser pensada, planejada e executada de modo a traduzir o conceito de uma obra editorial, cabendo portanto ao tipógrafo, a realização de um fazer que além de técnico é altamente interpretativo. E nesse caso, trata-se, com toda certeza, de um trabalho de linguagem, de conjugação entre conteúdo e forma.

Sendo assim, a tipografia é uma escrita idealizada e que vai ser pensada com liberdade de modo a dar voz ao seu conteúdo, ao estilo literário em que se insere. Nesse sentido, projeto tipográfico é um projeto com fim específico, que deve atender aos objetivos particulares daquilo que será impresso.

Desde o início da história da tipografia, como vimos, tipógrafos gravavam e fundiam tipos em determinados tamanhos e estilos para que fossem atendidos os anseios de uma obra a ser impressa. Um estilo revela um tempo, uma estética e uma série de valores que devem ser percebidos pelo tipógrafo.

Para entendermos a linguagem tipográfica, citamos neste capítulo alguns exemplos dos materiais e procedimentos utilizados pelo tipógrafo em seu ofício. Cabe no entanto dizer que, ao falarmos de técnica, estamos adentrando no campo da linguagem, visto que a linguagem tipográfica se particulariza a partir de seu meio e do modo de construção do objeto gráfico.

Nesse sentido, Elaine Caramella (1998) em sua obra, História da Arte fundamentos semióticos, aponta que: 
[...] estamos entendendo a técnica como associação que, baseada na experiência, codifica materiais na produção de signos e no estabelecimento de uma sintaxe numa obra. Por isso, podemos também afirmar que a técnica nunca é inocente ou ingênua, ou um mero elemento pejorativo, pois ela representa valor. Acontece, porém, que a sintaxe produzida pelos elementos técnicos nem sempre é passível de generalização. Daí sua dificuldade, mas também seu caráter e desafio (CARAMELLA, 1998, p. 77)

Pode-se afirmar, portanto, que a questão da técnica e o modo com o qual nos relacionamos a ela são decisivos na delineação da linguagem.

Na tipografia, o papel do tipógrafo frente ao projeto editorial e o modo de sua interação com o meio foi o que originou as divisões de atuação no ofício. Como consequência disso, percebemos na história do livro uma gama de possibilidades no campo da criação e da linguagem editorial.

Cabe ainda dizer que o estudo da linguagem gráfica de Aloisio Magalhães parte desse entendimento. Ou seja, de descobrir e debater os limites de interação do artista frente à tipografia e qual foi a sua contribuição ao projeto editorial no Brasil. Mas o momento ainda se reserva para discutirmos um pouco mais a respeito da linguagem tipográfica, sua técnica e a atuação do tipógrafo.

A história da tipografia nos revela que todos os avanços tecnológicos influenciaram de modo direto na criação e produção dos tipos, bem como o modo de se compor e editar textos. Assim tivemos a composição manual com os tipos móveis (sucessora ao livro manuscrito), a composição à quente ou mecânica com a linotipo, a composição à frio provinda da fotocomposição e por fim a composição digital.

As mudanças tecnológicas forçaram a adaptação dos desenhos dos tipos, transformaram e reorganizaram a produção do meio impresso e, como consequência, não só alteraram o papel do tipógrafo como também fizeram surgir 
novas categorias no modo de produção do livro. Cabe aqui discutir tais mudanças no sentido da técnica e da linguagem para, mais adiante, analisarmos estas divisões e onde o artista gráfico Aloisio Magalhães inseriu-se.

Segundo Claudio Rocha (2002), quanto à relação entre a evolução técnica e a linguagem tipográfica:

[...] desde o início, a tipografia estabeleceu relações que, além dos aspectos estéticos e econômicos, priorizaram fundamentalmente as questões técnicas. Por exemplo, no século XVIII o design tipográfico impulsionou a evolução da técnica de impressão. Os responsáveis pelo desenvolvimento dos tipos buscavam a melhor reprodução de seu trabalho e os tipos com grande contraste entre as hastes dos caracteres, com traços muito finos, só foram possíveis com 0 aprimoramento dos sistemas de impressão e da produção de papéis e tintas adequados [...] (ROCHA, 2002, p. 18)

Devemos entender, portanto, que os avanços tecnológicos que priorizaram as questões técnicas, tanto no desenvolvimento dos tipos como nas etapas de composição e impressão dos livros, acentuou a distancia entre o tipógrafo e sua interação com o meio impresso. Ou seja, ao mesmo passo que a tecnologia auxiliou o tipógrafo na otimização das etapas da construção do objeto gráfico, automatizou o seu contato com o mesmo.

Basta vermos, séculos mais tarde, a diferença entre o conceito que guardava o termo "Artes Gráficas" e atualmente, "Tecnologia gráfica". Importa-nos neste estudo, entendermos o caminho desta evolução no sentido da criação, da composição e linguagem gráfica - no papel do tipógrafo e artista gráfico espelhados na produção editorial. 
Ao tratarmos de comunicação impressa, ainda são forte os ecos do que Marshall McLuhan preconizou anos atrás. Sim, "o meio é a mensagem" e seus estudos repercutem a trajetória da tipografia que migrou do "meio quente" das páginas dos livros para o "meio frio" da tela do computador. Nas palavras de McLuhan em sua obra a Galáxia de Gutenberg "[...] a tipografia foi a primeira mecanização de um antigo artesanato e levou facilmente à crescente mecanização de todo artesanato [...]." (McLuhan, 1972, p. 74).

Essa crescente mecanização alterou profundamente o modo de raciocínio frente ao projeto gráfico. Mais do que isso, ofereceu ao mundo impresso a possibilidade de fragmentação entre quem projeta e quem executa. Mas é claro que devemos ter muito cuidado com esta afirmação, pois nela se concentra uma série de questões nos campos de atuação e do fazer gráfico.

Esse debate é a própria trajetória de Aloisio Magalhães, em todas as suas fases, e que se acentua ao final da década de 1950, quando se vê diante à uma nova tecnologia, o offset. Seu raciocínio muda a partir de então. De gráfico-artesão, que interage com o processo de criação e produção do livro, exercendo literalmente o papel de "mão suja"16 na oficina tipográfica d'O Gráfico Amador, volta-se ao campo do design. Seu raciocínio frente ao projeto muda, assim como o modo de se relacionar com a construção do projeto gráfico.

Destinaremos então algumas linhas para a especificação dos sistemas de composição em tipografia, na intenção de explorar os avanços tecnológicos dos mesmos e seus reflexos frente ao projeto editorial. O aprofundamento dessas

\footnotetext{
${ }^{16}$ A sociedade organizada pelos membros d'O Gráfico Amador adotava um curioso jargão como nos aponta Guilherme Cunha Lima em sua obra O Gráfico Amador - as origens da moderna tipografia brasileira. Existia uma divisão de duas categorias dentro de tal sociedade: "os chamados 'mão limpas' que não sujavam as mãos com tinta de impressão por não participarem diretamente da produção dos livros, e os 'mãos sujas', que sujavam as mãos produzindo os livros" (CUNHA LIMA, 1997, p. 96).
} 
questões concentra esforço para a análise do papel do gráfico e de como o mesmo se relaciona com o projeto editorial. Julio Plaza em sua obra Tradução Intersemiótica, cita W. Benjamim:

[...] os meios de produção e as relações de produção artísticas são interiores à própria arte, configurando suas formas a partir de dentro. Nessa medida, os meios técnicos de produção de arte não são meros aparatos estranhos à criação, mas determinantes dos procedimentos de que se vale o processo criador e das formas artísticas que eles possibilitam (PLAZA, 2010, p. 10)

A composição manual é o mais antigo sistema de composição tipográfico. Suas matrizes, os tipos móveis, antes mesmo de serem fundidos em um liga de metal, exigiam do tipógrafo um trabalho artesanal para a produção da chamada punção, matriz em alto relevo que era esculpida manualmente. ${ }^{17}$ Segundo Claudio Rocha, “[...] essa técnica se difundiu pela Europa e eram os próprios impressores que produziam suas matrizes e fundiam os tipos. No final do século XV a técnica tipográfica já estava caracterizada como um ofício." (ROCHA, 2002, p. 19).

\footnotetext{
${ }^{17}$ Segundo o autor Fred Smeijers em sua obra Counter Punch: Making Type in the Sixteenth Century, Designing Typefaces Now, "a punção é a forma da letra recortada em uma barra de aço de boa qualidade e tamanho compatível com o trabalho a ser feito sobre ele. Para se fazer a punção, iniciamos com a contra-punção, que nos dá a parte interna da letra. Esta forma deve, antes de tudo, ser recortada em uma pequena barra de aço no sentido correto em que aparecerá no papel [...] algumas contra-punções servem para diversas letras [...] as punções são peças de aço, cortadas em comprimento padrão de aproximadamente duas polegadas, e amolecidas por fogo incandescente [...] Após fazer a cavidade no meio da letra com a contra-punção, a próxima operação é eliminar as rebarbas das extremidades" (SMEIJERS, 1996, pp. 91 - 97).
} 

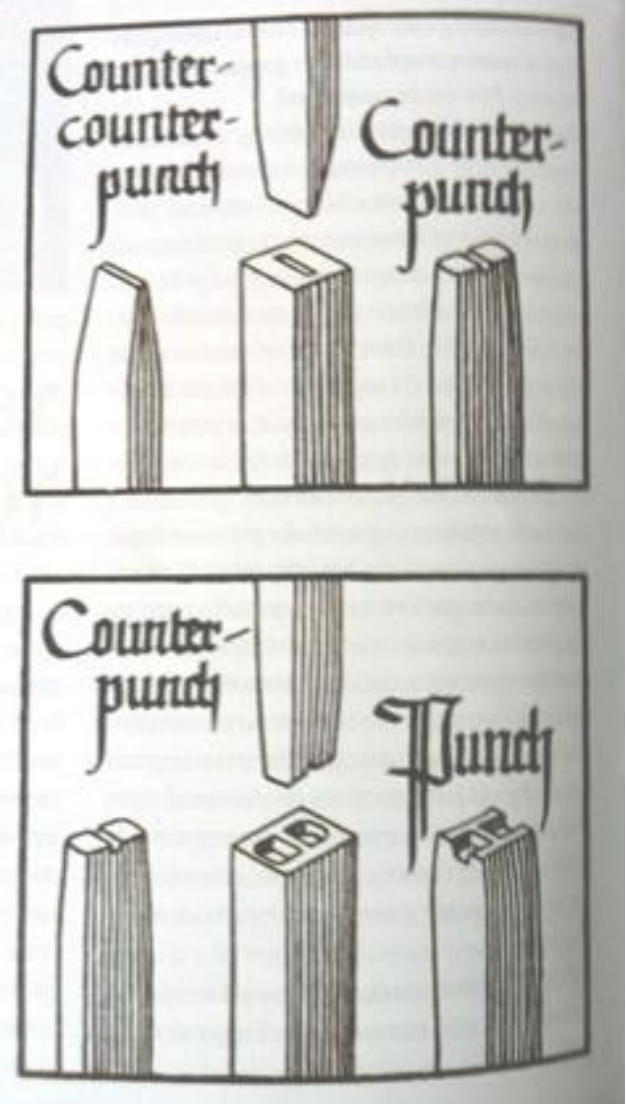

Ilustr. (34) Punção e contra-punção

Fonte: ROCHA, 2011, p. 32.

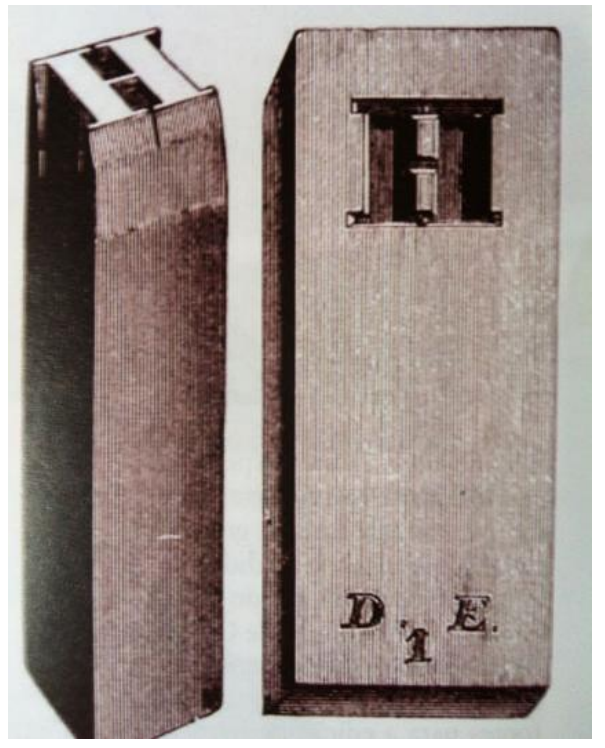

llustr. (35) Punção e matriz da letra $\mathrm{H}$.

Imagem de Theodore Low De Vinne

The Practice of typography, 1900

Fonte: ROCHA, 2011, p. 33. 


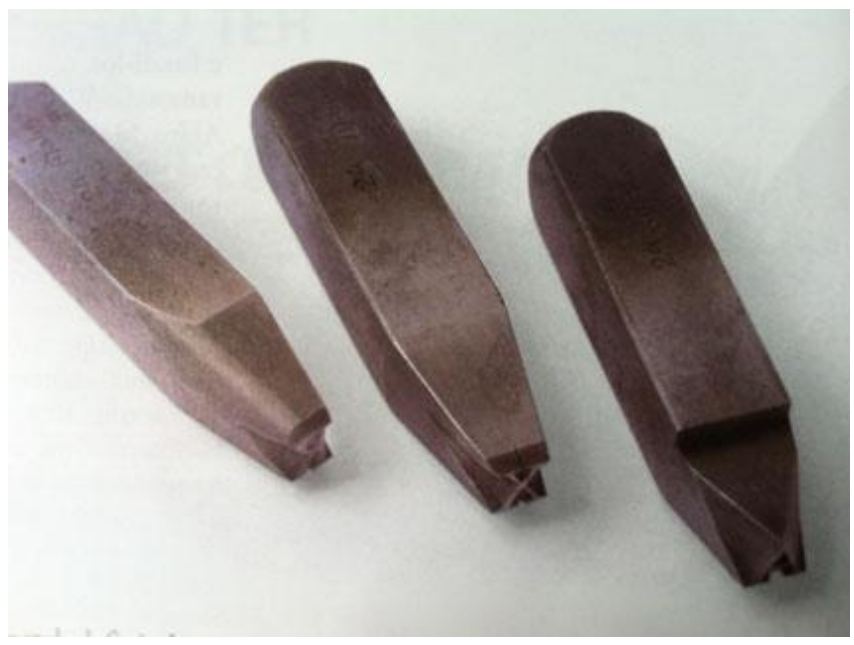

Ilustr. (36) Punções do tipo Tallone

produzidas pelo francês Charles Malin, em 1955.

Fonte: ROCHA, 2011, p. 33.

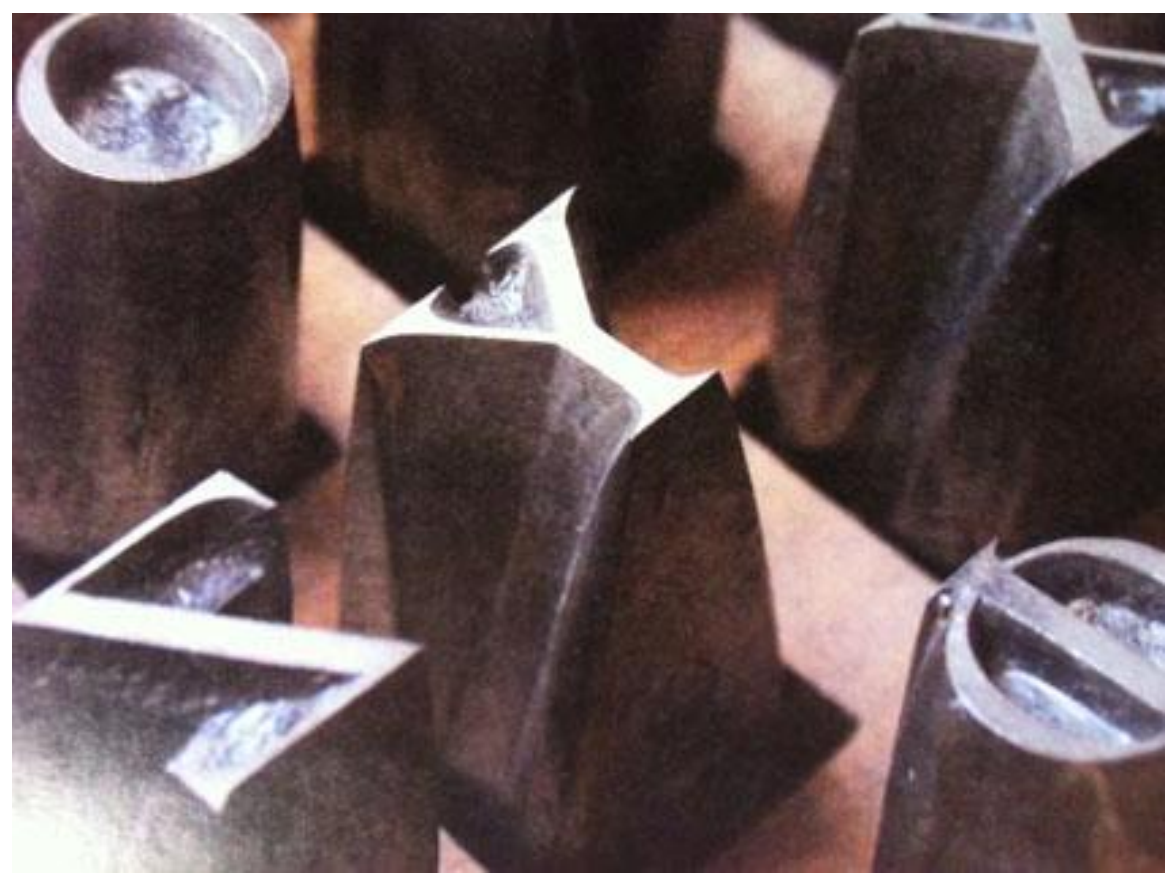

Ilustr. (37) Punções de Claude Garamond em exposição no Museu Platin Moretus - Antuerpia, Bélgica Fonte: ROCHA, 2011, p. 34. 
$\mathrm{Na}$ história da tipografia podemos verificar que já havia, nessa etapa de produção, uma divisão de categorias. Ou seja, encontramos registros de tipógrafosgravadores, de tipógrafos-gravadores-impressores, de exímios gravadores que atuavam somente nesta etapa da produção e ainda outros desdobramentos de tais categorias que iremos especificar mais adiante neste estudo.

Aqui nos cabe a especulação da técnica e de suas particularidades para que possamos diferenciar o modo de interação do tipógrafo frente às etapas de produção do objeto gráfico. Obviamente que este tipo de análise, tem enquanto objetivo maior, a verificação de como essas mudanças resvalam na linguagem gráfica.

Como vimos, o início da tipografia exigiu do tipógrafo uma interação quase que absoluta em seu meio de produção. E, provavelmente, não seja leviano de nossa parte dizer que o tipógrafo, nessa fase, se posicionava diante da produção do livro como coautor. Sua participação no projeto editorial era muito grande e dependia de seus esforços criativos e conhecimentos técnicos a sua realização.

A concepção, criação e produção do livro, nesse sentido, acontecia dentro dos limites de uma oficina tipográfica em contato direto com seus materiais. Nesse contexto, podemos imaginar como nascia o livro impresso e como era o contato do editor com o tipógrafo, o que também marcou uma importante categoria na história da tipografia: o tipógrafo-editor. O fato é que o livro pensado e produzido dentro de uma oficina tipográfica era um projeto acompanhado do início ao fim, ou seja, o conjunto desse produto gráfico era aquecido pelo contato direto com seu meio.

A história do livro impresso encontra sua evolução imbricada às questões de linguagem e técnica tipográficas. Mas todo cuidado é pouco no uso do termo "evolução", pois o livro impresso já nos fins do século XV e meados do século XVI possuía requinte e alta sofisticação técnica, tanto no sentido da sua diagramação, 
projeto tipográfico, impressão como em seu acabamento (exemplo disso são os livros impressos pelo tipógrafo, editor e impressor, Aldo Manuzio, entre 1449 e 1518, na Itália).

Em 1884, Otmar Mergenthaler criou e produziu um sistema revolucionário para a composição em tipografia. Foi o primeiro sistema mecânico de composição e fundição de tipos, a linotipo.

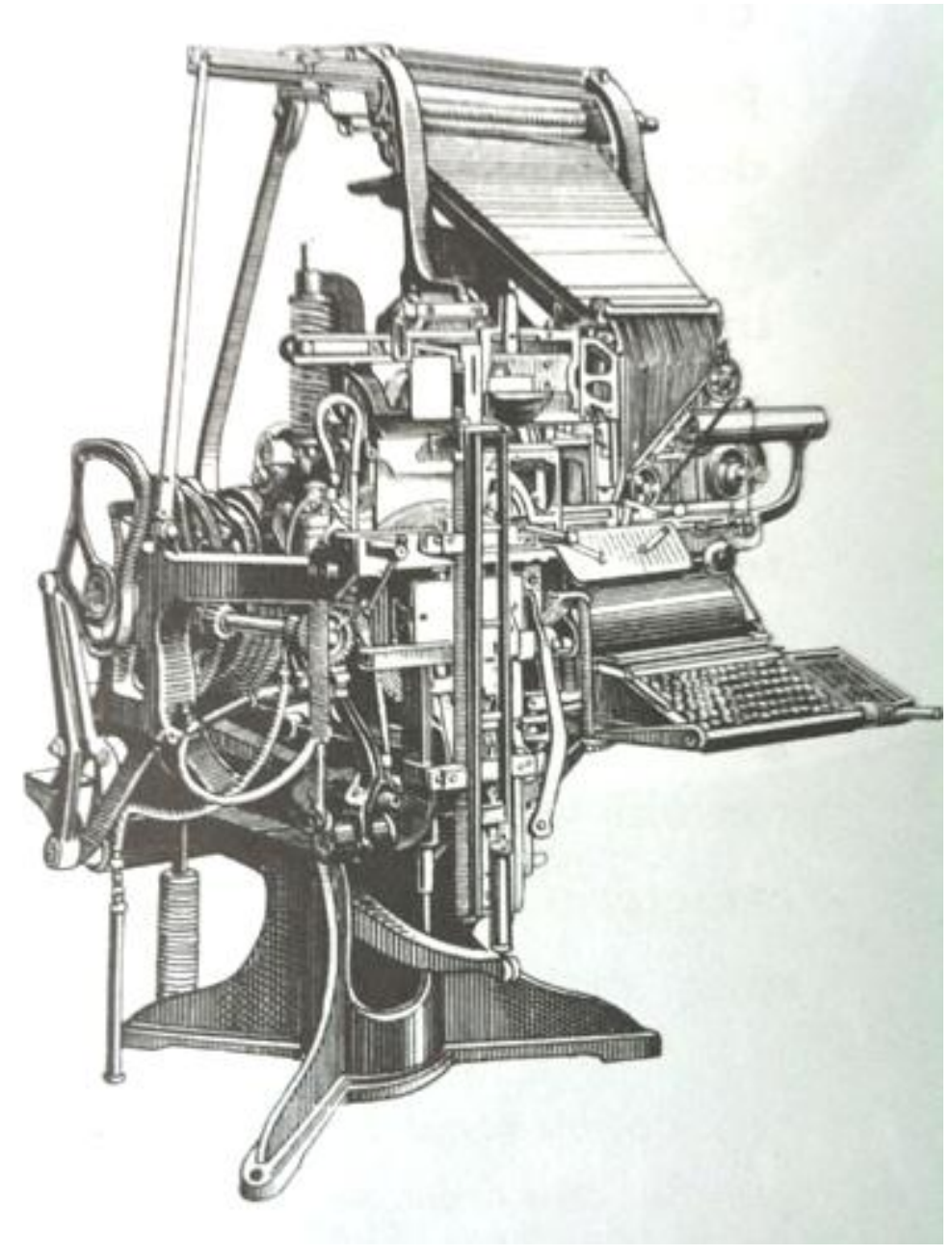

Ilustr. (38) Linotipo

Fonte: ROCHA, 2002, p. 19. 
Esse equipamento consiste de um teclado que aciona um magazine com as matrizes $^{18}$ de tipos que formam as linhas em medida estipulada. A linha é transportada e fundida pelo conjunto de fundição da máquina e, na sequência, as matrizes são devolvidas automaticamente ao seu respectivo magazine. Desse modo, o linotipista automaticamente compõe, funde a linha e distribui as matrizes de volta ao seu magazine. O termo linotipo provém de linotype que por sua vez significa o que produz, ou seja, "a line of type".

Sem dúvida alguma essa foi uma das grandes mudanças ocorridas no sistema de composição tipográfica, pois enquanto o tipógrafo, na composição manual, compunha uma linha selecionando e unindo tipo por tipo, a linotype compunha e fundia uma linha por inteiro. Ao final de seu uso na impressão, a linha poderia ser novamente derretida e a liga de metal completaria novamente a caldeira com sua matéria prima. Daí a razão deste sistema também ser conhecido como composição a "quente" além de composição "mecânica".

Esse equipamento, fabricado pela Linotype, fundia tipos em corpos menores para a composição de textos. Em meados do século XX, surgiram as máquinas da Monotype e da Ludlow, que também tinham a capacidade para fundir tipos em corpos maiores. Ficaram conhecidas como tituleiras. Essas três empresas desenvolveram volumosos catálogos de fontes para uso nos seus respectivos equipamentos.

\footnotetext{
${ }^{18}$ A "matriz" na linotipo deve ser entendida como o molde da letra a ser fundida, diferentemente do sentido empregado aos tipos móveis que também podem ser chamados de matrizes. Na verdade, enquanto o último é o objeto a ser entintado, a primeira se configura como o molde a ser fundido para ser criada a linha e por último ser entintada. As matrizes da linotipo possuem uma combinação específica em cada uma das letras, como um segredo de chave, para que possam ser distribuídas na seção correta do magazine depois de percorrerem a chamada "barra de distribuição".
} 
Durante anos, experientes designers e profissionais estiveram envolvidos em projetos tipográficos que hoje se tornaram clássicos e, em sua maioria, foram adaptados para os novos sistemas que foram surgindo (ROCHA, 2002, p. 20).

A linotipo, portanto, traz uma série de mudanças não só ao campo da composição tipográfica como também e, principalmente, ao mundo dos impressos periódicos. A agilidade e rapidez na composição atendeu o tempo da notícia e sua constante mutação. Assim foi nos principais jornais do mundo como o The New York Times, que chegou a contar com aproximadamente quatrocentos linotipos.

Junto à figura do tipógrafo surge nesse momento o linotipista, um profissional gráfico, conhecedor dos princípios em tipografia e que era instruído para operar este novo instrumento de composição. Uma nova tecnologia à serviço de um novo tempo da comunicação impressa.

Sem dúvida, esse invento, além de introduzir profundas mudanças no setor, deu ao profissional gráfico um novo posicionamento diante do seu fazer. Há claramente um distanciamento da composição para o setor de impressão. Enquanto o tipógrafo compunha manuseando os tipos e fechava sua fôrma tipográfica para imprimi-la, o linotipista concentrava-se nas operações mecânicas de sua composição.

São vários os relatos destes profissionais comparando uma tecnologia à outra, mas não muito congruentes em suas opiniões. É evidente que ao se distanciar do manuseio dos tipos, o linotipista assumiu um novo papel dentro da cadeia de produção do impresso e, assim, no modo de interagir com objeto gráfico.

O trabalho com os tipos, portanto, é a construção e interação direta com seu produto, reflexo de seu meio e do papel que, por conseguinte, seu agente assume. Seu modo de aproximação e contato com os materiais faz com que se estreitem as 
relações entre técnica e linguagem, ao passo que, a automatização da composição conteve a liberdade do processo de criação no que se refere a diagramação do texto no projeto gráfico. Um exemplo claro disso é a possibilidade do trabalho de espaçamento e kerning ${ }^{19}$ na composição manual, menos flexível em uma composição em linotipo.

Uma gráfica que trabalhasse nos moldes deste sistema operacionalizava a produção dividindo o trabalho dos linotipistas. Nos jornais, as laudas eram divididas pelo número de linotipistas em seu quadro de funcionários no intuito de dinamizar o tempo da composição. Os chamados "paquês"20 das linotipos, com as linhas fundidas, encerrava o trabalho do linotipista, salvo, é claro, se houvessem emendas de texto. Dessa maneira, a composição era reunida e encaminhada para o setor de impressão.

\footnotetext{
${ }^{19}$ Segundo o tipógrafo Claudio Rocha, "[...] a forma das letras, ou seja, a sua parte interna, somente pode ser percebida em conjunto com as áreas em branco ao seu redor, ou a sua contra-forma. Tecnicamente, a qualidade de uma fonte é definida pela legibilidade e harmonia na composição de palavras e textos. Portanto, o ritmo e a cor de um bloco de texto estão relacionados com o equilíbrio entre as formas das letras e suas respectivas contra-formas, mais a justaposição dos caracteres em sequência, na formação das palavras. Para conseguir isso, um projeto de fonte tipográfica pede dois ajustes de natureza complementar: espaçamento e kerning". (ROCHA, 2002, p. 44). Entende-se espaçamento como o espaço entre os caracteres. Os ajustes que se fazem neste sentido, tomam um grupo de caracteres para o aumento ou a diminuição dos valores deste intervalo. Já o Kern é um termo originário dos tipos de metal. Ele representa a parte de uma letra que avança sobre o espaço de outra. Seu ajuste é feito entre pares de letras.

${ }^{20}$ Os "paquês" são chapas planas que se assemelham `as galés ou bolandeiras na composição manual. Nas linotipos elas são acopladas às máquinas para que o linotipista ordene a produção das linhas fundidas.
} 


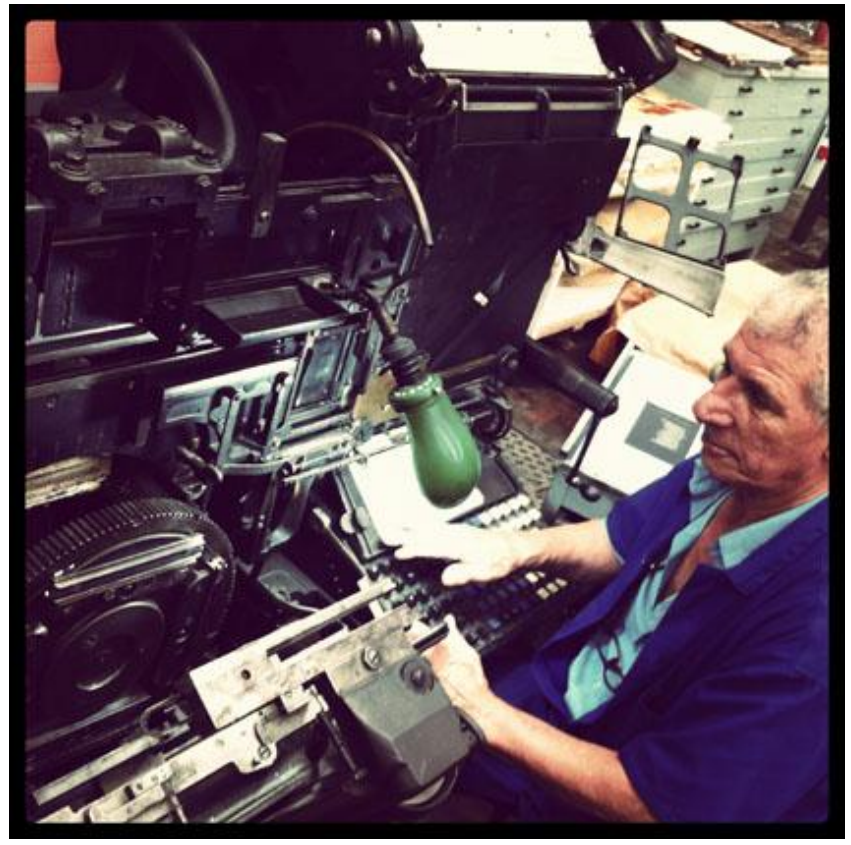

Ilustr. (39) Sr. Figueiredo, popularmente conhecido como "Paraná".

Linotipista da Oficina Tipográfica São Paulo

Fonte: Oficina Tipográfica São Paulo

Foto: Marcos Corrêa de Mello Felisette

Nesse intervalo da produção (entre a composição das linhas e a impressão) era necessário um profissional gráfico, muitas vezes um tipógrafo, que "fechava" a composição diagramando-a no formato a ser impresso. Cabe ressaltar que, nesse período, as gráficas de grande porte contavam com máquinas rotativas com vazão para altas tiragens. Operavam por um sistema de transferência da composição ${ }^{21}$ plana para os cilindros, o que fez com que se desmembrasse o antigo fluxo de trabalho do tipógrafo também na etapa de impressão.

\footnotetext{
${ }^{21}$ O sistema de transferência da composição plana para o cilíndrico era feito através do "Flan" cujo princípio está ligado a estereotipia. A composição das páginas de impressão em linotipo eram gravadas em um suporte semelhante a um cartão de papelão com a imagem positiva em baixo-relevo. A partir de então, este cartão chamado de "Flan", recebia um jateamento de liga de chumbo no formato de uma telha para ser posicionado nos cilindros das impressoras rotativas. A matriz "Flan", neste processo continha novamente a imagem gravada em negativo para ser impressa corretamente.
} 
Esse período da tecnologia gráfica fez com que o projeto editorial fosse mediado por outras mãos. Como vimos, o linotipista e mesmo o gráfico encarregado na impressão - muitas vezes um tipógrafo conhecedor das novas tecnologias - não se responsabilizava por inteiro da produção do impresso. Mas o que teria acontecido com a produção do livro?

Nelson Palma Travassos em sua obra, Livro sobre Livros, nos revela um panorama não muito animador do Brasil no setor editorial da década de 1920. Relata a falta de livros e a concentração das bibliotecas apenas nas capitais. Segundo ele, "[...] os autores nacionais, parnasianos, românticos, realistas, transplantavam literatura alienígena de nenhum interesse popular. Era uma literatura de enfeite, de salão, restrita a uma sociedade mundana, provinciana, sem horizontes." (PALMA TRAVASSOS, 1978, p. 57). Ainda nas palavras do autor vemos que:

O Brasil nasce com Monteiro Lobato, em 1918, com a publicação de seu livro "Urupês" e o grupo que em torno dele se aglutinou falando dos problemas nacionais. Afrânio Amaral, Navarro de Andrade, Adolf Lutz, Osvaldo Cruz, Artur Neiva, Emílio Ribas, Euclides da Cunha e outros desta envergadura abriram os novos horizontes do Brasil, do Brasil que combateu Mauá, que conheceu Lobato.

Lobato começou a tratar da doença brasileira adotando o remédio que foi prescrito a D. João VI pelo conde de Linhares - criando uma outra imprensa nacional - de livros. Para isto contou com um profissional extraordinário, Natal Daiuto que, por sua vez, e apoiou em outro homem a quem o Brasil muito deve, Savério D'Agostino. Daiuto montou e dirigiu as oficinas gráficas da "Editora Monteiro Lobato". Com sua técnica criou a linha impressora de livros no Brasil e forjou homens, como seu auxiliar, então mocinho, Theobaldo De Nigris [...] em 1924 Monteiro Lobato, em face das razões conhecidas, faliu. Em 1927 retomamos o plano de Monteiro Lobato. E aquilo que não era exequível em 1924, já o era em 1927, tanto assim que Octalles Marcondes Ferreira e Monteiro Lobato, fundando a "Cia. 
Editora Nacional", sentiram a necessidade de, conjuntamente, acoroçoarem a criação de uma grande tipografia que se dispusesse a imprimir livros. Chamam então o velho Daiuto e Savério D’Agostinho que fundam a "São Paulo Editora". (PALMA TRAVASSOS, 1978, p. 57, grifo do autor)

Tal relato revela a importância de empreendedores como Monteiro Lobato, Octalles Marcondes Ferreira e o próprio Nelson Palma Travassos que, além de tipógrafo, foi diretor presidente da "Gráfica Editora Revista dos Tribunais". Se não a maior, com certeza essa empresa se configurou entre as maiores gráficas editoras do Brasil no período de 1920 a 1970.

Importante lembrar que esses empreendedores enfrentaram à época, além dos problemas políticos e estruturais de nossa economia, a falta de equipamentos e mão de obra qualificada para a expansão do setor gráfico. Grande parte do sucesso desses homens se deu não somente pelas estratégias inovadoras nos negócios editoriais, mas também pela busca incessante pela melhoria de seu produto, o livro.

Tanto Monteiro Lobato como Octalles Marcondes Ferreira e Nelson Palma Travassos tiveram visão e consciência daquilo que se necessitaria realizar no campo gráfico para tais melhorias. Organizaram seus parques gráficos adaptando modelos provindos da Europa e Estados Unidos com a importação de máquinas tipográficas mais modernas. A Segunda Grande Guerra possibilitou ampliação na compra destes maquinários, principalmente as linotipos como nos conta o autor:

A Segunda Grande Guerra, que se avizinhava de modo incontrolável, teria certamente efeitos semelhantes, quintuplicados. Daí a convicção da necessidade de expansão da nossa indústria, até então apetrechada, apenas para atendimento do, ainda bisonho, comércio editorial vigente [...] sem perda de tempo entabulamos grandes compras de impressoras, metal de composição, numeroso conjunto 
gráfico, enfim [...] simultaneamente adquirimos à Mergenthaler, além das que já possuíamos, mais vinte e seis linotipos de vários modelos e construímos as nossas modernas instalações, à Rua Conde de Sarzenas, 38. Assim, com senso de oportunidade, situamos a "Empresa Gráfica da Revista dos Tribunais", acima de todas as suas congêneres brasileiras (PALMA TRAVASSOS, 1978, p. 61, grifo do autor)

Mas, como já fora citado, de nada adiantaria todo aparato de máquinas sem mão de obra especializada. Mais que isso, era preciso a criação de um sistema capaz de mover o conjunto da produção gráfica do livro, que desse maior vazão de produção conjuntamente às expectativas de melhorias de seu produto. Esse empreendimento, além do mais, teria a difícil tarefa de concentrar esforços no estreitamento com os autores, no acompanhamento do projeto gráfico, na impressão e, por fim, na distribuição.

Resolvida a equação, poderia se pensar no sucesso da transposição do antigo modelo limítrofe das pequenas tipografias para a configuração de um novo e quem sabe promissor modelo gráfico editorial. Daí a importância de profissionais como Natal Daiuto, que nesta transição de modelos operacionais assumiu a responsabilidade no papel da produção editorial.

Coube à figura desse "novo produtor gráfico" a coordenação e execução do projeto, assim como fora de igual importância o papel de Plancher $^{22}$ no século XIX. Profissionais desse porte, além de contar com experiência nas artes gráficas, colocavam à prova sua criatividade e sensibilidade no fazer gráfico. Nesse sentido, pelo seu posicionamento junto a editora e a produção gráfica, davam o tom de

\footnotetext{
22 Pierre Plancher era profissional francês das artes gráficas e trouxe para o Brasil do século XIX, o grafismo estético da arte de impressão francesa. Segundo Luiz Santa Cruz : "[...] o livro e o impresso brasileiro em geral, até mais da metade do século XIX, viveram sob o signo de Plancher" (SANTA CRUZ apud HALLEWELL, 2005, p. 146).
} 
identidade ao produto. Afinal, um projeto gráfico editorial não é somente a tradução de seu conteúdo. Possui identidade própria mas tem a incumbência de espelhar a identidade de sua casa editorial. A história das editoras e de seus respectivos projetos nos contam todo este mover.

Voltemos nossa atenção à análise da produção do livro e de sua relação com o meio técnico a partir das mudanças ocorridas no parque gráfico brasileiro nos anos de 1930 e 1940.

As transformações que se fizeram notar durante tais décadas nos levam a compreender uma série de questões a respeito da configuração desse produto, bem como em seu modo produtivo, como vimos. Mas nos interessa investigar o ponto em que se encontrava a relação entre a criação da linguagem gráfica, a produção do livro e o papel destes artistas gráficos, mediadores no processo de concepção editorial do livro. Segundo Nelson Palma Travassos, nesse novo modelo de composição do livro:

[...] foi necessário a adoção de um processo de boletim com várias cópias, com a discriminação tecnicamente esquematizada de todos os detalhes da obra a ser confeccionada de modo a permitir a mudança da composição, por vencimento de horários dos operários, sem solução de continuidade da mão de obra. E o livro passou a ser fabricado em série, pelo processo de linha de montagem. Há porém, no seu fabrico, uma parte de sensibilidade que não exclui continuamente, a interferência do bom gosto de quem 0 esquematiza, ou por outra, do artista. Ora, a obra de arte é uma porção de sensibilidade visionada, e interpretá-la é historiar a existência interior de quem a subscreve. O organizador de originais tem que ser um artista. $E$ os artistas são como prima-donas do teatro lírico (PALMA TRAVASSOS, 1978, p. 46) 
A evolução dos meios tecnológicos, com o advento das máquinas offset, acirraram ainda mais a distância entre o projeto de criação e a execução do mesmo. Também é nítida a mudança no sistema de composição tipográfica com o surgimento da fotocomposição ou composição à frio, como também é conhecida. Esse modelo de composição foi o primeiro a utilizar o processo fotográfico e apareceu no cenário gráfico em meados de 1947, mas foi somente na década de 1960 que este sistema veio a atingir seu máximo aperfeiçoamento.

Isso se deu, como afirma Claudio Rocha, devido à "[...] evolução da impressão offset, que permitia reproduções com melhor definição e, consequentemente, maior qualidade final. Os sistemas de fotocomposição eram incrivelmente mais rápidos, comparados aos sistemas mecânicos." (ROCHA, 2002, p. 20).

Aprofundaremo-nos na técnica de offset no Capítulo IV desta pesquisa, que propõe a análise da experiência de Aloisio Magalhães com esta tecnologia. Foi neste período, de 1957 e 1959, que ele desenvolveu, em parceria com o artista gráfico Eugene Feldman, dois livros experimentais em offset: Doorway to Portuguese e Doorway to Brasilia. O resultado desse trabalho é uma justaposição de questões referentes à linguagem gráfica de Aloisio Magalhães e o debate sobre o papel do artista frente ao próprio fazer gráfico.

\section{O TIPÓGRAFO: ENTRE A ARTE E A CIÊNCIA}

Discutimos anteriormente a evolução dos meios técnicos e como os mesmos influenciaram o posicionamento do tipógrafo frente ao seu ofício. Vimos também que 
se por um lado essas mudanças dinamizaram o fluxo de produtividade no meio gráfico, aumentaram de vez a distância entre o setor de criação e a produção gráfica - não é à toa que hoje em dia enviamos um "arquivo fechado" para uma gráfica realizar a impressão.

Discutimos, também, que a técnica tipográfica é responsável pelo delineamento de sua linguagem. É a partir do contato com seus materiais, que o tipógrafo pensa, organiza e compõe o objeto gráfico. Dessa maneira, Ihe compete dar forma e sentido para a composição, interpretar e requerer da linguagem tipográfica o caminho para a transposição do texto manuscrito para o texto composto tipograficamente. Portanto, o modus operandi com o qual o tipógrafo concebia um livro ou impresso composto manualmente concedeu a ele a qualidade de mediador. Na produção do livro impresso ele teve papel fundamental junto ao editor, exercendo por que não, nesse sentido, a coautoria da obra.

Ressalta-se também que, ao seguirmos esse raciocínio diante do ofício tipográfico, estaremos debatendo o tênue limite entre arte e ciência. Norberto Gaudêncio Junior em sua obra A Herança Escultórica da Tipografia, em relação ao tipógrafo, nos aponta o fato que "[...] sua função de mediação e padronização, reflete o novo paradigma imposto pela tipografia, em que as habilidades manuais do artesão serviam a um processo criativo que devia tanto à arte quanto à ciência." (GAUDÊNCIO JUNIOR, 2004, p. 32).

A técnica tipográfica estabeleceu limites formais ao impresso e aflorou como pensamento e razão à luz de uma época:

Essa orientação pela temporalidade é, de resto, a pedra de toque dos princípios impostos pelo pensamento renascentista, mais notadamente a invenção da perspectiva cartesiana. Capaz de quantificar o espaço tridimensional, abstraindo e reduzindo todo o 
complexo sensorial à uma experiência estritamente visual, a perspectiva exigia pontos de vista determinados e fixos. Essa neutra imobilidade impunha ao leitor da página impressa uma relação espácio-temporal onde o "ver é acreditar" [...] Fica claro que, como tecnologia racionalizante, a tipografia enquadra-se perfeitamente no ideário artístico renascentista, que buscava na justificação matemática do desenho a própria retorização da pintura, escultura e arquitetura (GAUDÊNCIO JUNIOR, 2004, p. 33, grifo do autor)

Por mais que a técnica se responsabilize por novos materiais, meios e também métodos é a figura do homem que reconhecemos como centro das ações para a mudança e direcionamento do uso de uma tecnologia. Pierre Lévy nos chama atenção ao assunto apontando o fato de que o homem "[...] desviando e reinterpretando as possibilidades de uso de uma tecnologia intelectual, atribui a elas um novo sentido [...] o sentido de uma técnica nunca se encontra determinado em sua origem." (LÉVY, 2000, p. 146).

Assim, podemos entender que a tipografia, enquanto modelo tecnológico, sempre esteve mediada ou posta à prova pela razão de seu tempo. Enquanto linguagem sempre estabeleceu o diálogo com a estética do momento, afirmando-a ou negando-a com maior ou menor veemência. Desse modo, também reconhecemos a participação da tipografia junto aos movimentos artísticos de vanguarda no século $X X$ na Europa.

Para exemplo dessa questão, utilizaremos como referência para o debate do assunto no próximo capítulo, tipógrafos, poetas e artistas gráficos que trilharam este fronte. No momento nos cabe traçar o posicionamento do tipógrafo enquanto agente mediador no processo de construção do livro para que possamos ampliar nosso debate acerca do ofício gráfico. 
Nelson Palma Travassos traz, em seu depoimento, a voz de quem foi, como ele, um artífice da profissão: editava e imprimia livros. No decorrer de sua vida (1903 - 1984), percebeu e sentiu as mudanças tecnológicas transformarem o artesão gráfico em operário moderno ao passo do seu tempo. Nas palavras do autor,

\begin{abstract}
Antigamente, quando a arte gráfica não era mecanizada, a um mesmo tipógrafo competia fazer tudo: ler os originais, compor a mão as páginas com os tipos de caixa, emendar as provas e imprimi-las. $\mathrm{O}$ serviço exigia uma atenção maior e requeria um maior número de aptidões. O tipógrafo era um artífice completo dentro da profissão. Com o andar dos tempos, a tipografia crescendo, foi tendo suas seções subdivididas e especializadas. A composição passou a ser mecânica, com a introdução das linotipos. Desapareceu o tipógrafo componedor, para em seu lugar, surgir o linotipista [...] hoje o tipógrafo é um técnico especializado em determinada coisa: uma marca original, isto é, escolhe os tipos e as capitulares, determina o corpo dos títulos e subtítulos, faz o esboço da paginação, etc. [...] enorme é a interferência do desenhista que executa, podemos dizer, tudo quanto há de arte na tipografia, pois o desenho gráfico tornou-se uma especialidade artística (PALMA TRAVASSOS, 1978, pp. 188, 189)
\end{abstract}

Como nos aponta o autor, as transformações tecnológicas, ocorridas ainda no século XIX, que mecanizaram o trabalho do tipógrafo ao criarem a fratura entre arte e tecnologia na indústria gráfica, estabeleceram um novo sentido de planejamento e construção do livro. Isso é, a industrialização do livro ao mecanizar o seu fabrico. Segundo Rafael Cardoso, em O Design Brasileiro antes do design (2005, p. 161): “[...] garantiu um grau de padronização jamais visto na história do livro e promoveu, por conseguinte, uma natural valorização do projeto, sobretudo no caso do livro ilustrado.". Ainda decorrendo das palavras do autor, 
[...] trata-se de uma regra geral na história do design: reduzindo-se na etapa de execução o impacto da habilidade manual do trabalhador especializado (no caso, impressores, compositores, tipógrafos) aumenta-se a importância da concepção e do planejamento como formas de garantir a qualidade final do produto (CARDOSO, 2005, p. 161)

É claro que devemos guardar esta afirmação ao momento de transição do que era tido enquanto artes gráficas e o que mais tarde veio a ser instituído como tecnologia gráfica. O fato é que nesse ínterim, com a subdivisão do trabalho na cadeia de produção do livro, escapa ao tipógrafo a totalidade da construção do projeto. Como vimos, a industrialização no setor gráfico, teve reflexos imediatos junto ao planejamento e impressão dos livros.

Não nos cabe no momento realizar detalhadamente uma cronologia acerca da história do livro no Brasil e de sua relação com as editoras que aqui fizeram nome. Mesmo porque, tal assunto vem sendo explorado nos últimos anos por pesquisadores da mais alta importância em nosso país. Mas compete, nesta pesquisa, apontar a relação do projeto do livro e as editoras, para entendermos, por fim, os seus reflexos diante da produção gráfica, ou melhor, em quais mãos a criação e planejamento do livro repousaram. Segundo Edna Cunha Lima e Márcia Christina Ferreira:

[...] entre 1930 e 1937, o setor livreiro no Brasil viveu um surto de industrialização que interferiu diretamente no mercado editorial. Mudanças sócio econômicas deixaram o livro nacional, pela primeira vez na história, em nítida vantagem sobre os livros importados [...] Getúlio Vargas ascendeu ao poder e promoveu uma série de mudanças estruturais no ensino público nacional por meio do então Ministério da Educação e Saúde [...] o número de editoras brasileiras, 
cerca de uma dezena, chegou a dobrar entre 1936 e 1944, atingindo um pico de produção na década de 1950, quando contou com 4 mil títulos e publicou cerca de 20 milhões de exemplares ao ano (LIMA; CHRISTINA FERREIRA, 2005, p. 197)

Por volta das décadas de 1940 e 1950 - época de incremento e de grande expansão da indústria do livro - se contou muito com a criatividade do desenhista, do ilustrador ou artista gráfico, pessoas que ligadas ao campo da cultura das artes gráficas, permitiram um novo e melhor posicionamento do produto editorial no cenário brasileiro.

O projeto gráfico, nas mãos desses profissionais, ganhou um novo feitio. A construção do projeto editorial como um todo, nesse sentido, tendeu a alcançar uma nova estética, bem como, agregar sua identidade à editora. As boas casas editoriais, como vemos na história de modo geral, tendem a ser reconhecidas pelos seus catálogos de obras, juntamente com o estilo gráfico adotado em suas coleções.

São vários os artistas em nosso país que representaram essa época áurea, como: Tomás Santa Rosa para as capas e projeto gráfico da José Olympio; Di Cavalcanti em período um pouco anterior (1910 - 1930) para a Editora Americana e Editora Guanabara; o ilustrador e produtor gráfico Luís Jardim no período de (1942 1969) e Raul Brito; Rubens Barros Lima, produtor e responsável pelos projetos gráficos da Editora Civilização Brasileira (década de 1940 em diante); o artista alemão Walter Lewy para a companhia Editora Nacional; Eugênio Hirsch (década de 1960) também para a "casa", como era chamada a Editora José Olympio.

O design gráfico no Brasil revela grande parte de sua história pelas páginas do livro impresso. Pesquisadores como Guilherme e Edna Cunha Lima, Rafael Cardoso e Chico Homem de Melo são alguns dos importantes nomes que investigam a rica produção gráfica de nosso país, em períodos que não 
conhecíamos o design como é hoje conhecido. Outro grande pesquisador do livro no Brasil é, sem dúvida alguma, Laurence Hallewell. Em sua obra, O Livro no Brasil Sua História, o autor nos revela que:

Os livros com o sinete editorial da José Olympio logo começaram a destacar-se da insípida mediocridade dos concorrentes, pois o editor, desde o início, dedicou cuidadosa atenção ao projeto gráfico. Seu colaborador nessa área, mais uma vez, foi um nordestino, Tomás Santa Rosa, que trabalhara anteriormente em diagramação e em desenhos de capa para a Schmidt [...] começou sua carreira artística - muito influenciada por Portinari - que envolveria não apenas pintura e artes gráficas como ilustração de livros, cenografia, direção de cena, ensino e crítica [...] Provavelmente será lembrado, sobretudo, por sua obra teatral, mas tem sido considerado o maior produtor gráfico de livros no Brasil, responsável, quase sozinho, pela transformação estética do livro brasileiro nos anos de 1930 e 1940 (HALLEWELL, 2005, pp. 462 - 463)

É importante dizer que, se por um lado o avanço tecnológico no campo gráfico instituiu de vez o modelo industrial para a produção do livro, destituiu, em grande parte, a responsabilidade do tipógrafo na construção do projeto editorial. Coube à figura do editor, além de sua visão empreendedora, a regência da produção livreira na coordenação de artistas, ilustradores e artistas gráficos. O projeto do livro, a partir de então, estava definitivamente a cargo de outros profissionais. Basta entendermos até que ponto a criação do projeto era gerida nos limites do espaço de uma oficina gráfica. 


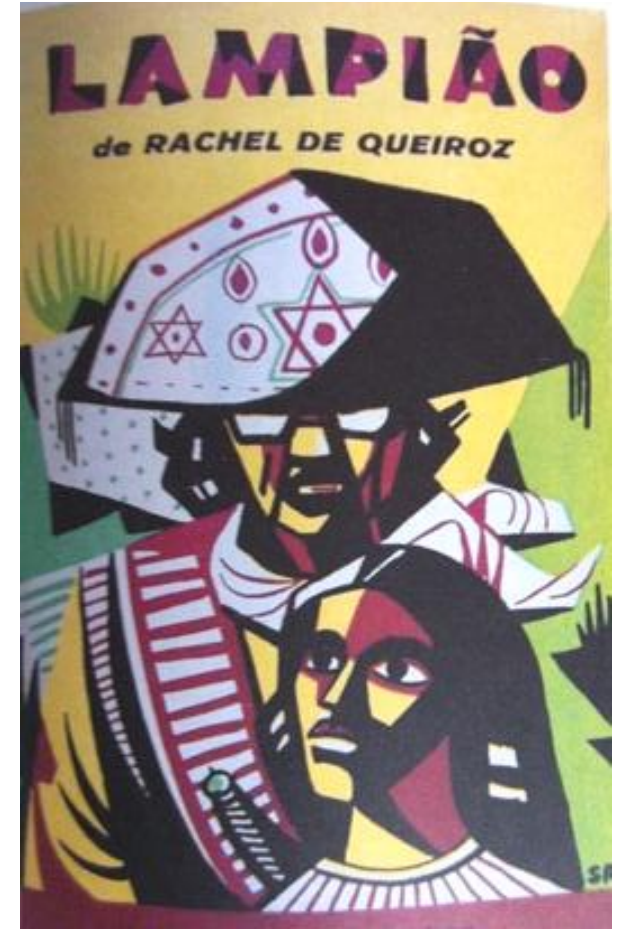

Ilustr. (40) Capa de Santa Rosa

para Lampião, 1952

Fonte: CARDOSO, 2005, p. 231

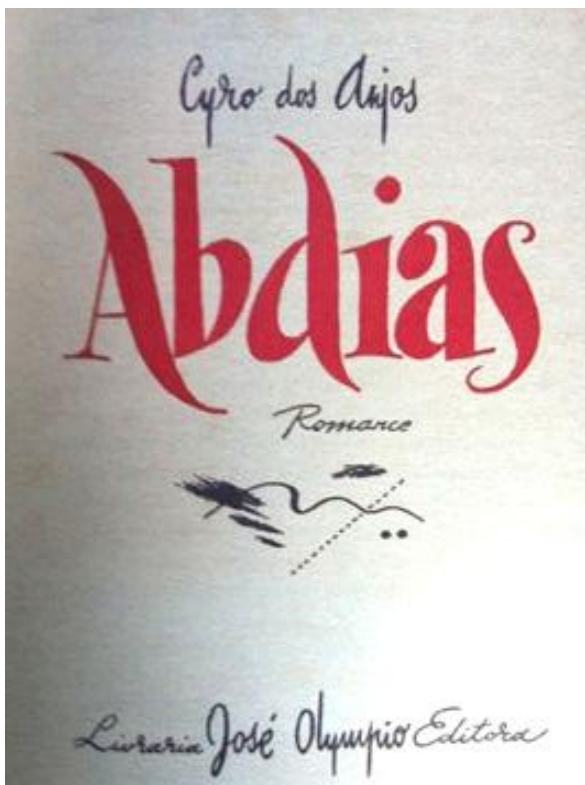

Ilustr. (42) Capa de Santa Rosa

para José Olympio, na década de 1940

Fonte: CARDOSO, 2005, p. 219

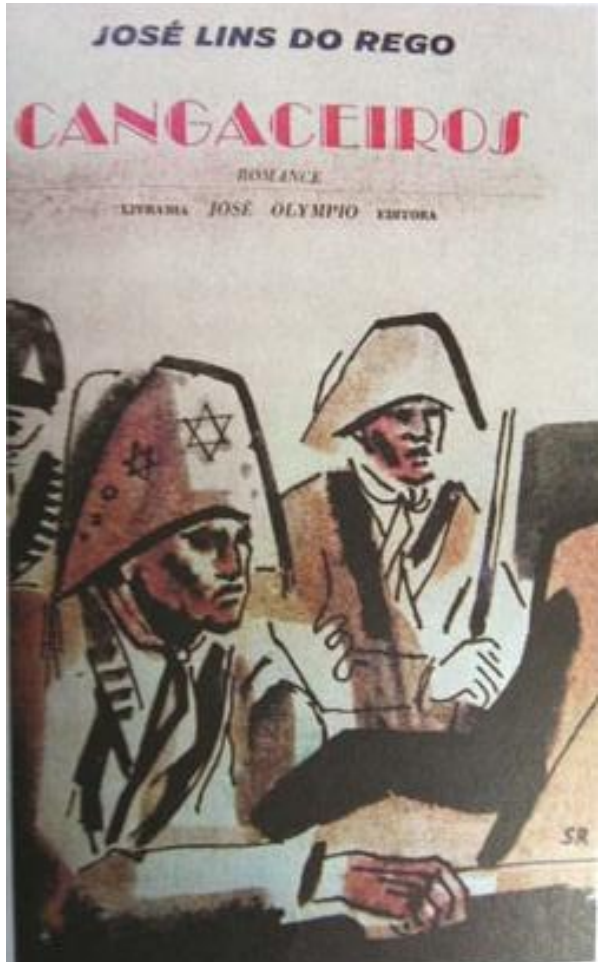

Ilustr. (41) Capa de Santa Rosa

para Cangaceiros, 1955

Fonte: CARDOSO, 2005, p. 227

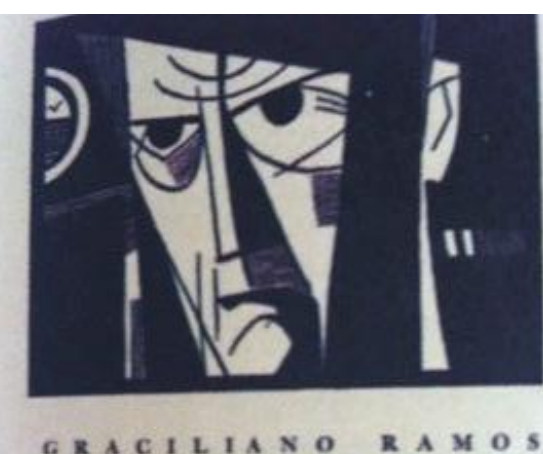

\section{Mentórias do Cárcere}

1. Tacke - Vuaksk

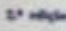

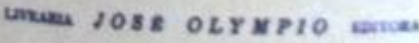

Ilustr. (43) Capa de Santa Rosa, 1953

Fonte: CARDOSO, 2005, p. 215 
Ainda neste capítulo, iremos recorrer à períodos um pouco mais longínquos na história da tipografia, a fim de compreender os papéis exercidos pelo tipógrafo, o editor e a produção do livro. No curso deste entendimento, verificaremos o panorama das categorias que assim se delinearam ao longo do desenvolvimento do livro impresso.

A Renascença agregou duas tarefas simultaneamente à tipografia: a primeira, humanística, junto à segunda, de ordem artística. Ao contrário do que aconteceu no século $\mathrm{XV}$, quando a inexperiência e o espanto diante de tal invento tomara conta dos tipógrafos-impressores, o mesmo não ocorreu no século seguinte.

A partir do século $\mathrm{XVI}$, vemos um panorama diferente tomar conta deste ofício, dada a compreensão do seu alcance ao mesmo passo da superação técnica. Aliado a isto, nos parece que o tipógrafo do século $\mathrm{XVI}$, ao unir as tarefas de conhecimento e beleza, incorpora o espírito de sua época. Segundo Wilson Martins em seu livro, A Palavra Escrita, o autor nos explica que:

[...] o século XV não havia criado, praticamente, senão a ideia da tipografia, mostrou que ela era possível e como era possível. Mas a imensa e complexa aparelhagem de que ela necessitava para obter a sua fisionomia e o seu rendimento próprios, ainda restavam por criar. O problema dos impressores renascentistas era, assim, antes de mais nada, um problema de ordem industrial - a disposição de utensílios necessários para obter economicamente o seu produto - e um problema de ordem estética - fazer desse produto o que realmente devia ser, isto é, uma obra de arte, e não apenas uma mercadoria (MARTINS, 1957, p. 224, grifo do autor) 
Vemos também que o livro ao se revestir de seus valores materiais, enfatizou a importância da palavra impressa, a escrita fixada e que deste modo, assumia a condição de autenticidade e fidelidade. Diferente da cultura manuscrita, que transformava a comunicação verbal em experiência relativamente visual (GAUDÊNCIO JUNIOR, 2004) posto o modo de sua leitura, em voz alta e sujeito à interpretações quando lida em público.

O livro impresso alterou esta dinâmica, trazendo a leitura para uma experiência individual movida à estrita condição visual. Com isso, "[...] a tipografia afastou a palavra de sua original associação com o som e a tratou mais como coisa no espaço." (ONG apud MCLUHAN, 1972, p. 19). Esta nos parece ser a compreensão alcançada por quem compunha e editava o livro a ser impresso no século XVI.

Quando nos referimos aos tipógrafos e impressores do século em questão, devemos, portanto, entender que a tarefa de compor e imprimir tinha como principal intento a questão de editar algo. Assim, impressores e tipógrafos eram em uníssono "editores”, pois era na acepção da palavra o que estes faziam.

[...] tratava-se nada mais nada menos, do que editar pela primeira vez, toda a obra escrita da humanidade. Aqui o problema era da autenticidade e o da fidelidade. O "editor", que era um humanista, da mesma forma por que, como o "impressor", devia ser um artista, media na exata proporção as suas responsabilidades [...] no montão valioso, mas em grande parte suspeito dos manuscritos medievais, sua primeira tarefa era a de verificar até que ponto cada um deles pertencia efetivamente aos seus pretensos autores [...] os erros de cópia, as adulterações, as variantes, as mutilações, tudo fazia com que os manuscritos medievais fossem, ao mesmo tempo preciosos, insubstituíveis e imprestáveis (MARTINS, 1957, p. 226, grifo do autor) 
A imprensa, que dava seus primeiros passos, tinha como tarefa reatar com o mundo antigo ao mesmo tempo em que "verificava" a autenticidade de tudo aquilo que fora registrado pela via manuscrita. O "editor", portanto, deveria ser uma pessoa instruída de conhecimento e não só portadora das capacidades técnicas do ofício. Quem se “[...] dizia 'impressor', no século XVI e nos seguintes, se dizia ao mesmo tempo um 'homem instruído, um erudito mesmo', sempre consciencioso e honesto, tendo apenas uma paixão, a da ciência." (MARTINS, 1957, p. 226).

E não é difícil entendermos que, do contrário, de nada valeria a grande chance que a invenção da imprensa alcança no contexto da expansão cultural e comercial com a propagação das oficinas tipográficas.

Clara é também a importância daquele que, capacitado culturalmente e familiarizado com a técnica de composição e impressão tipográfica, saberia dar vazão ao impulso renascentista. Deveria ser culto, para abraçar a oportunidade como reeditar por exemplo, os clássicos da cultura helênica mas também, acima de tudo, ser uma pessoa de visão comercial.

$\mathrm{O}$ contexto em que se insere o livro do século $\mathrm{XVI}$ em diante, do ponto de vista de sua elaboração e produção, tem enquanto artífice principal, a figura do editor. "[...] Desde o século XV, os impressores eram forçosamente artesãos e eruditos ao mesmo tempo, sucedendo aos copistas anteriores que tinham sido, fatalmente também, latinistas, universitários e clérigos." (THÉRIVE apud MARTINS, 1957, p. 299).

Mas é necessário entender que muitos dos grandes editores, tipógrafos e impressores se fundem a uma só pessoa, como é o caso de Aldo Manuzio (Bassiano, 1450 - Veneza, 1515), cuja vida e obra são o maior exemplo do que é 
ser simultaneamente, editor, tipógrafo e livreiro. Podemos ver algumas diferenças dentro destas categorias, mas a verdade é única para a concepção de um livro, e talvez seja este o grande ensinamento dos mestres renascentistas.

Isto é, para se editar, imprimir e comercializar verdadeiramente um livro é necessário que se entenda este tripé. Ou, nas palavras do maior estudioso da vida de Manuzio, que nos relata que ao fazer um livro não deveríamos abrir mão "[...] da sábia e bela harmonia renascentista, construída com a proporção equilibrada dos três conhecimentos básicos, perenes e inerentes ao venerável ofício: os do editor, os do tipógrafo e os do livreiro." (SATUÉ, 2004, p. 42).

A obra de Aldo Manuzio não é foco desta pesquisa, mas exemplifica da melhor forma possível o papel daquele que se propõe a editar um livro do ponto de vista de sua concepção, ou melhor, dos desafios de entendermos a chamada arquitetura do livro, do projeto editorial e de como lidamos como todo este conjunto de elementos, entre eles logicamente, a tipografia.

Não nos cabe aqui explorar tal assunto, como também discutirmos a respeito das regras de composição de um livro. Mas não é demais citarmos alguns bons exemplos que a escola Aldina nos deixou como legado. Entre elas, além das que já foram citadas, é bom que se diga da sua grande contribuição para o que temos hoje enquanto formatação do livro. Segundo estudo de Satué:

[...] para começar, em se falando do editor, destacam-se: a lista de títulos inéditos, especialmente os clássicos gregos-latinos, selecionados por um critério insuperável, excepcionais e oportunos; perfeição editorial também extrema, inédita para a época - e mesmo hoje se quisermos ser sinceros -, com traduções, comentários e edições a cargo dos espíritos mais refinados daquele tempo; a fundação da Academia Aldina, também chamada Neoacademia ou Academia da Fama; conselho editorial deslumbrante, formado de 
trinta e dois sábios e eruditos escolhidos no melhor celeiro da Itália e da Europa [...] se olharmos o tipógrafo, impõe-se reconhecer-Ihe o descobrimento pessoal do tipo cursivo, inclinado, chanceleresco, bastardo, itálico ou aldino; o achado do formato de bolso (Libelli portatiles in formam enchiridii, lia-se num catálogo de livros publicado em 1503); a extraordinária novidade da lombada plana; a criativa substituição da madeira pelo cartão nas capas dos livros, o emprego do pergaminho de cabra e a gravação nele com ouro aquecido [...] por último, se examinarmos a ação do livreiro, devemos creditar-Ihe: a primeira edição de catálogo com a relação de obras publicadas e respectivos preços; o agrupamento de livros, pela primeira vez numa única série ou coleção; o valor de troca do grego e do latim num mercado potencial e internacionalmente como era o da Europa humanista de seu tempo (SATUÉ, 2004, p. 43, grifo do autor)

Cabe-nos dizer que muitas destas inovações ainda se conservam nos dias de hoje e que a obra de Aldo Manuzio no campo editorial é o exemplo da convergência intelectual, sensibilidade artística e comercial. Muito se assemelha, guardadas as suas diferenças e proporções, ao trajeto de outros grandes editores-tipógrafos, que assim como Manuzio, empenharam grande esforço no campo editorial.

O legado destes encontra-se vivo como exemplo da mais alta sofisticação feita ao livro impresso. A nós apenas cabe o reconhecimento e aprendizado de todo esse ensino. Nas palavras de Satué, "[...] Erasmo impressionava-se com a qualidade, rigor e categoria tipográfica das edições aldinas, as únicas - ao lado de outra insigne família de tipógrafos: os Elzevir holandeses." (SATUÉ, 2004, p. 62). 
PRIMVS

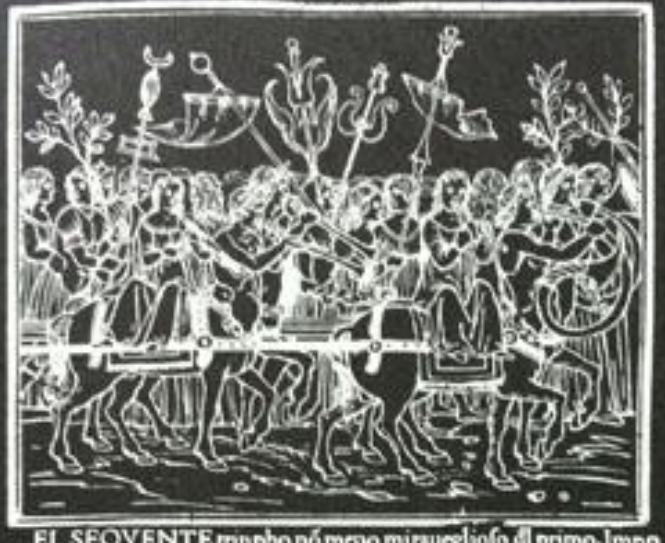

ELSEQVENTE mophonó meno minueg liofo di prima. Impo

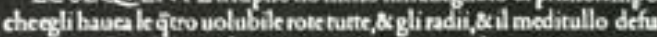
Coachate, di cidide uéule uagamete uaricato. Necalectranite gellocre

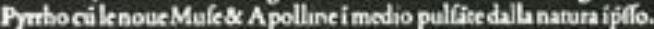

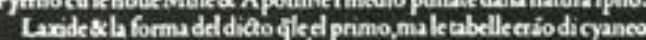
Saphyo orientale, atomato de fintilluledoro, alla magiea gratifi mo, alongo accepeiflimo acupodinenella finiftramano.

Nella ubella dextma mirai exfealpto una infigne Matröa che dui oui haves parturito, in uno cubile regio colloca a, diuno mirabike pallacio, Cum obfertice ftu pefacte, \&mulve alterematrone \&aflante NympheDrgliquali uiriua de uno una fammula, oxdehl. too ouo dac f patatifi me falle. $*$ *

Ilustr. (44) Página dupla ilustrada do livro Hypnerotomachia Poliphili, de Francesco Colonna, Venenza, 1499, in-fólio, 202 × 312 mm. Fonte: SATUÉ, 2004, p. 127. 


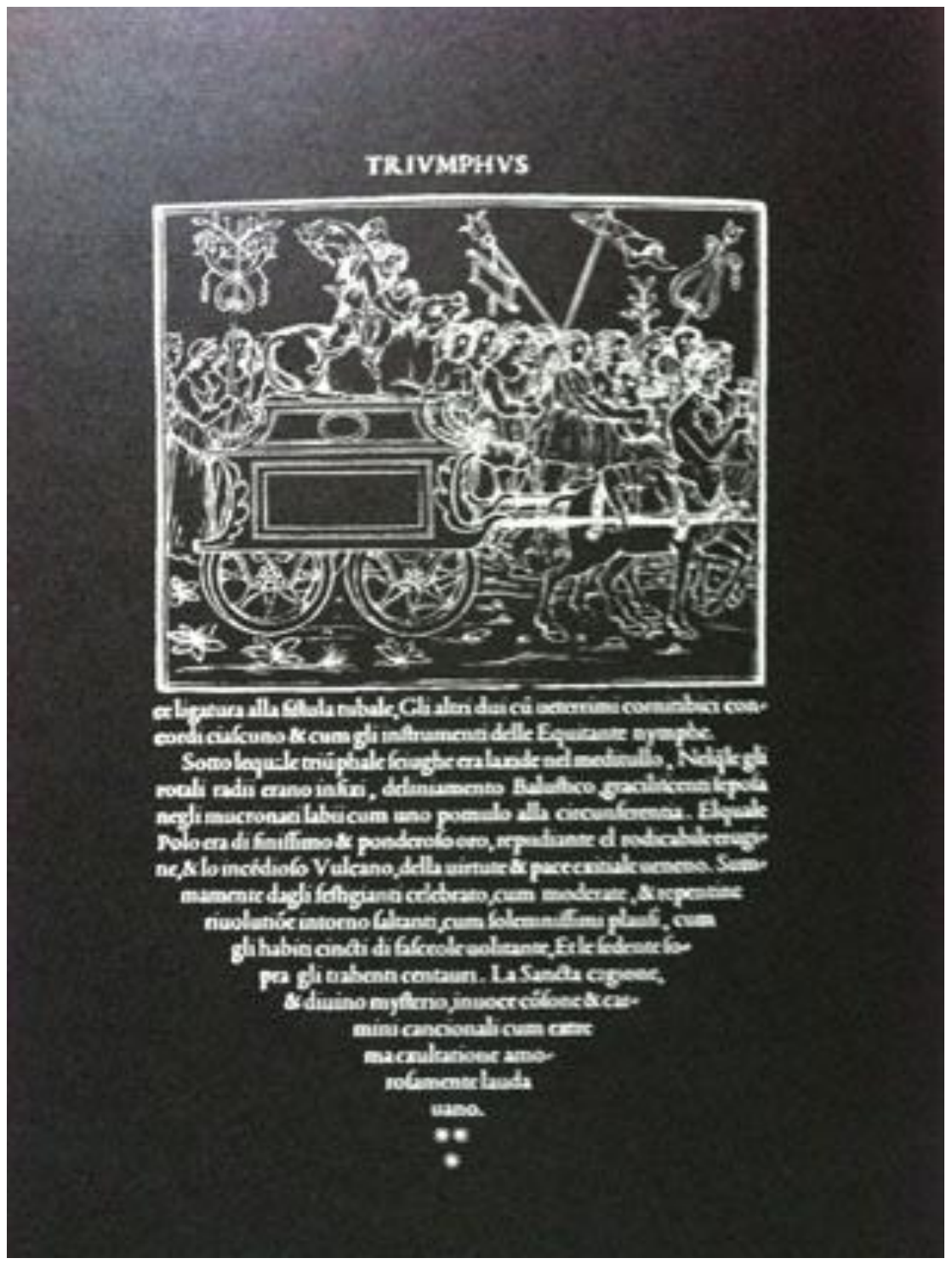

Ilustr. (45) Página dupla ilustrada do livro Hypnerotomachia Poliphili, de Francesco Colonna, Venenza, 1499, in-fólio, 202 × 312 mm.

Fonte: SATUÉ, 2004, p. 126.

Quanto à gravação e fundição dos tipos, Manuzio contou com um grande colaborador, Francesco Griffo. Considerado como o mais perfeito gravador não só dos tipos gregos, sua grande contribuição se deu também com os tipos latinos e hebraicos, além é claro, da cursiva aldina. 
Vemos, portanto, que a história do livro impresso se funde à história da tipografia. Em diferentes graus e escalas de aproximação, seus agentes intercederam na evolução das técnicas e no sentido estético do livro, apurando aquilo que Gutenberg outrora havia proposto: um novo tempo ao livro. Rapidamente ao passo de tal invento, foi grande o número de empreendedores que se puseram a ir atrás desse conhecimento:

[...] assim fez o francês Nicholas Jenson que, antes de estabelecerse definitivamente em Veneza, trabalhou três anos no ateliê de Gutenberg [...] entalhou a primeira grande tipografia moderna, conhecida ainda hoje com o seu nome: Jenson [...] a tipografia Jenson inaugurou esplendidamente a ofensiva estilística renascentista, em contraposição à espessa e eclesiástica tipografia gótica imperante [..] iria ser a fonte de inspiração de todos os grandes projetistas tipógrafos posteriores: de Claude Garamond a William Caslon, entre os clássicos dos séculos de ouro, até William Morris, o grande propulsor da criação tipográfica pré-rafaelita de fins do século XIX (SATUÉ, 2004, p. 98)

Podemos no momento também nos inclinar à opinião de que Aldo Manuzio assim outros grandes tipógrafos- editores faziam de seu ofício algo não mecânico frente ao projeto editorial. Mais ainda, "[...] a alternância entre os conceitos de tipógrafo e projetista [...] não é de forma alguma fortuita, senão o fruto amadurecido de uma ação estética deliberada, consciente e refinada." (SATUÉ, 2004, p. 130). De Manuzio, herdamos concentricamente, os grandes postulados do projeto editorial, da composição tipográfica e da postura de um livreiro. Veremos no decorrer dos séculos, com a acentuada industrialização do livro, que este quadro irá criar fraturas. Mas ainda é fortuita a lição àqueles que nos dias de hoje, almejam entender um pouco mais a respeito da criação de um projeto editorial e de suas implicações. 
Outro grande pesquisador da história do livro é sem dúvida nenhuma, Robert Darnton. Em sua obra, $O$ Beijo de Lamourette $^{23}$, o autor propõe um gráfico interessante acerca do circuito de comunicação e de como se inserem as várias categorias de profissionais na cadeia de produção do livro. Tomamos sua análise para exemplificarmos o posicionamento do tipógrafo, do editor e do comercializador frente ao livro impresso. Faz-se necessário esclarecer, que o autor neste quadro, cria um modelo de comunicação que se aplica a todos os períodos da história do livro, mas com ênfase ao século XVIII. Assim podemos ver:

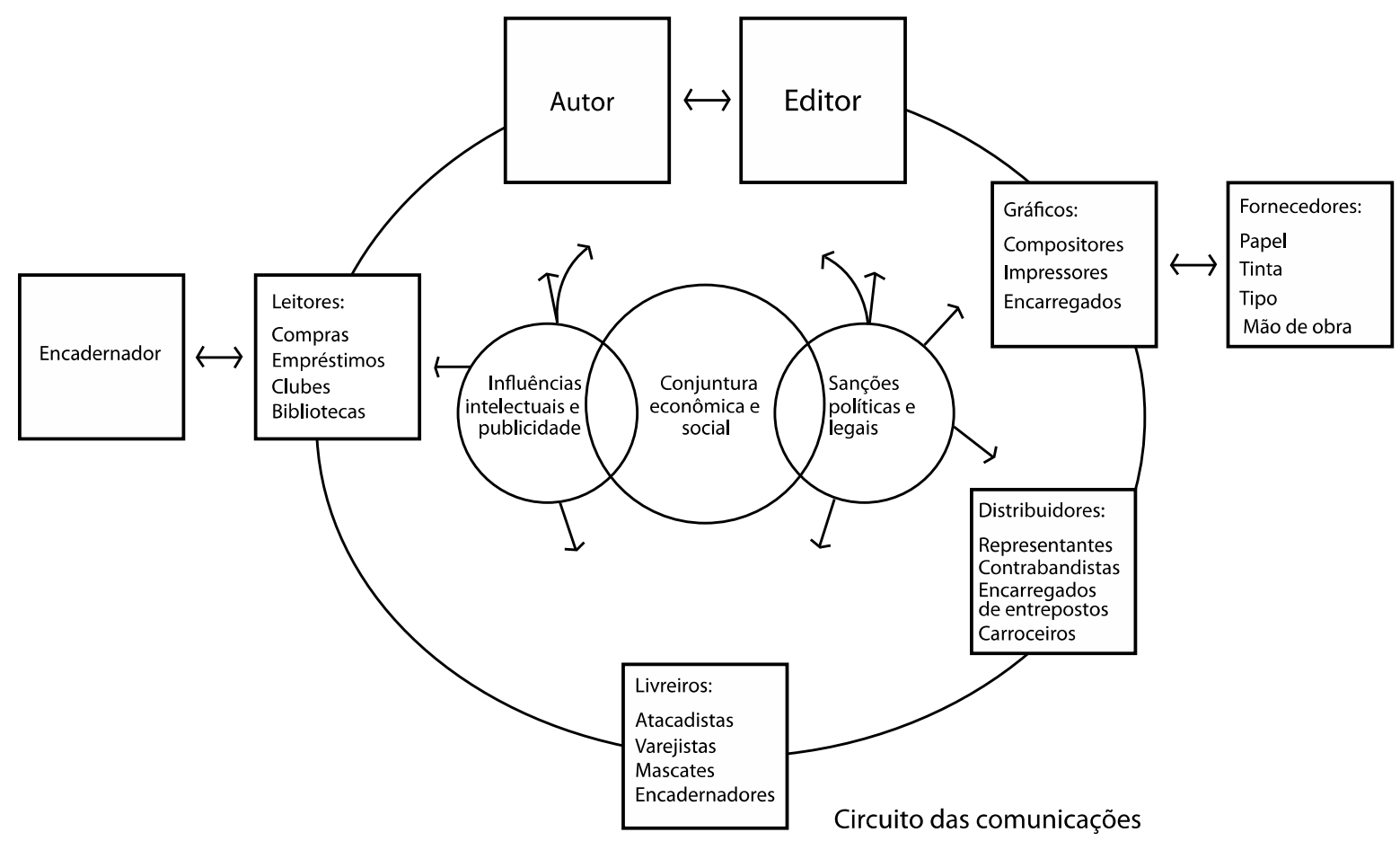

Ilustr. (46) O circuito das comunicações

Fonte: DARNTON, Robert. O beijo de Lamourette, 1990.

${ }^{23}$ DARNTON, Robert. O Beijo de Lamourette. São Paulo: Companhia das Letras, 1990. 
Dentre as categorias analisadas, o autor nos traz opiniões que convergem com a presente pesquisa no que tange ao posicionamento do editor junto ao tipógrafo e de como estes ao longo dos séculos, se desvincularam, estabelecendo uma nova dinâmica entre si.

Nas palavras do autor, "[...] a evolução do editor, como figura específica diferenciada do mestre livreiro e do impressor ainda demanda de um estudo sistemático [...] embora sejam as fontes mais ricas dentre todas para a história dos livros." (DARNTON, 1990, p. 124).

Assim como a figura do editor, a pesquisa de Darnton (1990) aponta a interessante condição dos "intermediários esquecidos" ou ainda caberia o termo como sugere Socorro de Fátima Pacífico Barbosa (2010), "os intermediários da leitura".

Podemos concluir, portanto, que a história do livro relaciona uma série de estudos interdisciplinares que merecem nosso esforço para conjuga-los ao seu objeto de estudo. E esta árdua tarefa, requer o exercício a qualquer pesquisador proposto ao estudo, de entender o conjunto de agentes neste processo de disseminação cultural. Portanto, a figura do editor na história do livro, relaciona-se com a própria condição deste diante do meio em que o projeto é gerado.

Como vimos, o modelo das oficinas tipográficas não desassociava os papéis entre editor - tipógrafo - impressor. É claro que as variações faziam-se presentes, criando nuances nestas categorias. Isto é, com maior ou menor interação em uma etapa específica, o editor, o tipógrafo ou o editor-tipógrafo projetavam o livro impresso.

Giselle Martins Venancio na obra organizada por Aníbal Bragança e Márcia Abreu, Impressos no Brasil - Dois séculos de livros brasileiros, nos cita a divisão de 
categorias do editor no Brasil, por Bragança (2002, pp. 57 - 83), a partir dos modos distintos de realização do projeto editorial:

[...] há três modos de edição distintos - e para cada um deles se pode considerar um editor paradigmático. O primeiro deles é o editorimpressor, na tipologia desenvolvida pelo autor, representado por Paula Brito; o segundo é o livreiro editor, representado por Francisco Alves, e o terceiro é o editor propriamente dito, que no caso da história editorial brasileira, é representado por Monteiro Lobato, que primeiro se destacou como editor desvinculado da tipografia e da livraria (BRAGANÇA apud MARTINS VENANCIO, 2010, p. 494)

$\mathrm{Na}$ presente pesquisa foi analisada uma obra francesa dos finais do século XIX, Le Livre du Bibliophile ${ }^{24}$, cujo conteúdo é de extrema valia no contexto desse debate. Como sabemos, a tipografia e o livro no Brasil devem boa parte de sua formação à influência europeia pelas mãos dos franceses e portugueses. Sabemos também, da influência de outras culturas como a dos holandeses e ingleses que aqui trouxeram sua parcela de contribuição à soma desta história.

Não nos cabe pelo momento e muito menos pela proposta a que a presente tese se destina, nos embrenharmos aos campos de tal investigação, aliás, tarefa muito bem coordenada por pesquisadores como Aníbal Bragança, Marcia Abreu, Cybelle de Ipanema, Edna Cunha Lima, Eliana de Freitas Dutra, Elizabeth W. Rochadel Torresini, Guilherme Cunha Lima, Rafael Cardoso, Sandra Jatahy Pesavento, apenas para citarmos alguns nomes ao peso e importância do tema que aqui nos detém.

No entanto, nos valemos desta pequena obra no intuito de trazermos o interessante relato de um editor, que com sua intimidade à tipografia e ao projeto

\footnotetext{
${ }^{24}$ LEMERRE, Alphonse. Le Livre du Bibliophile. Paris: Alphonse Lemerre, Libraire, 1874.
} 
editorial, aproxima-nos deste fazer. Vale complementar, que no Brasil, o modelo francês utilizado na tipografia ${ }^{25}$ não foi somente adotado pela forte influência dos franceses à nossa cultura, como também, pelo grau de proximidade entre nossas línguas maternas, razão esta evidente do latim.

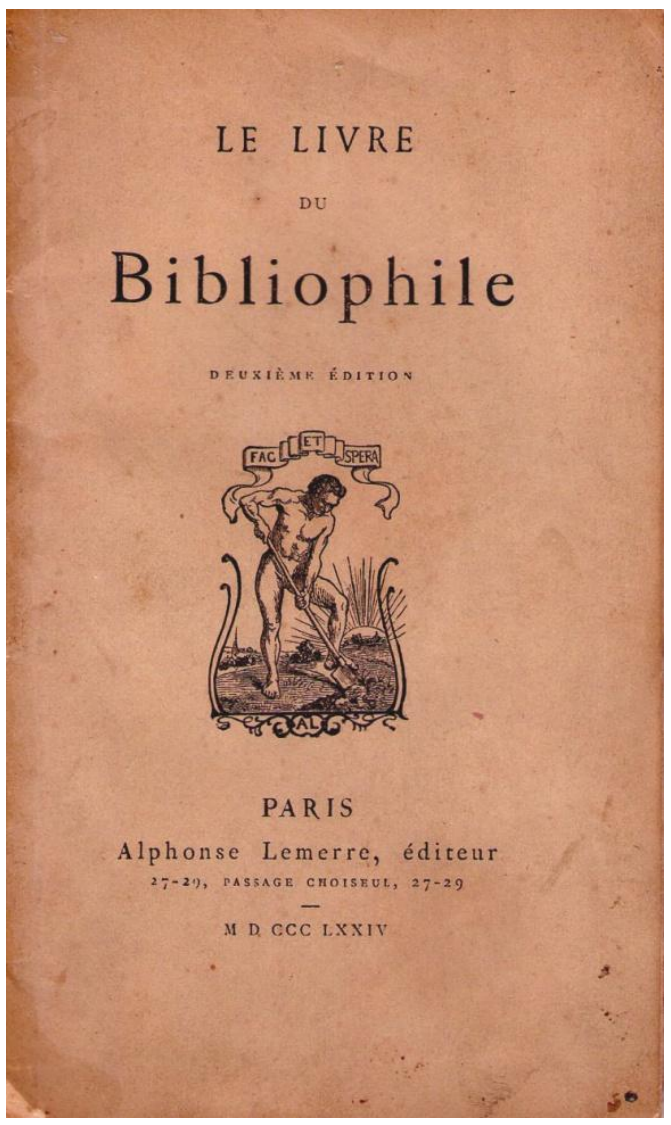

Ilustr. (47) Capa do "Livro do Bibliófilo"

Fonte: LEMERRE, 1874.

Foto: Marcos Corrêa de Mello Felisette

Alphonse Lemerre (1874) na qualidade de editor e profundo conhecedor das práticas do livro, faz de sua obra, um rico estudo para o bom desenvolvimento do projeto e sua execução. Divide suas práticas em editoração, composição manual e

\footnotetext{
${ }^{25} \mathrm{O}$ modelo francês que nos referimos é o sistema francês em tipografia, com suas medidas e distribuição de tipos à caixa francesa. Diferentemente do sistema inglês, que adota o sistema de medidas Anglo Americano. Vide introdução do capítulo - Tipografia.
} 
projeto gráfico, impressão, ornamentação e acabamento, comercialização. Sua obra, é para a época (e por que não aos dias de hoje?) um relato atencioso dos meandros do ofício de quem, por dentro de uma oficina tipográfica exerce seu trabalho. Iremos recorrer a alguns pontos específicos deste estudo de modo a finalizar este capítulo abordando as particularidades de uma oficina tipográfica como centro emergente de propagação cultural. Como a presente tese se propõe a investigar Aloisio Magalhães e sua linguagem gráfica, e sabendo de seu envolvimento junto a produção editorial dos anos de 1954 e 1961 n'O Gráfico Amador, resta-nos entender as especificidades gerais destas pequenas oficinas na intenção de entendermos como o projeto gráfico do livro era gerado a partir de seu meio. Mas o momento nos reserva o importante relato de Lemerre (1874), inicialmente quanto aos problemas editorias:

[...] Este trabalho visa delinear os principais pontos da arte a que nos dedicamos totalmente, bem como determinar as condições que, a nosso ver, devem necessariamente estar presentes em uma edição para que ela seja digna de ser apreciada e estimada por verdadeiros entendedores [...] Só falaremos da reimpressão de escritores antigos, não porque a publicação de obras contemporâneas nos pareça de menos valor, mas porque os textos antigos apresentam dificuldades particulares para o editor e também porque uma nova publicação desses textos universalmente conhecidos é vã quando não é quase definitiva [...] Vamos examinar em poucas palavras os cuidados que o Livro exige, desde a elaboração do manuscrito ou, para falar a linguagem técnica, da cópia a ser entregue ao tipógrafo, até o momento em que o volume completo entre, recoberto por sua encadernação, na vitrine do bibliófilo. Para esta longa série de operações tão diferentes, tão variadas, o livreiro-editor tem inúmeros auxiliares: homem de letras, fundidor, impressor, fabricante de papel, desenhista, gravador, brochador, encadernador etc., todos contribuem para o mesmo objetivo: a perfeição do livro, mas é 
importante que o livreiro-editor mantenha constantemente a harmonia da ajuda dada por eles na execução de um empreendimento que ele concebeu e da qual só ele pode abranger o todo (LEMERRE, 1874, pp. I - 2)

O texto nos indica claramente o posicionamento do editor enquanto coordenador de todas as etapas que envolvem o conjunto de produção do livro. Lemerre (1874) aponta para a harmonização das etapas que sucedem a construção do projeto bem como da compreensão de conjunto que o editor deve possuir. A este assunto, já decorremos neste capítulo e aqui reiteramos nosso posicionamento frente à dinâmica que se estabelece na divisão de tarefas no empreendimento do projeto editorial. Ao seguir deste estudo vemos que:

[...] editar um bom texto é de importância primordial. É aí que reside o objetivo fundamental de uma reimpressão, e os cuidados plásticos tão complexos de que esse texto será objeto, servirão apenas revelálo de acordo com todas as conveniências e, por conseguinte, com uma beleza perfeita. Todo o trabalho do editor terá sido em vão se não for exercido a partir de um texto irrepreensível. Ele deve pensar nisso e, se ocupar das coleções, se organiza bibliotecas clássicas ou curiosas, deve aplicar, quanto à publicação dos textos, algumas regras previamente determinadas, e contar com o concurso exclusivo dos literatos e dos eruditos que admitem essas regras [...] $O$ elemento essencial das boas edições está sempre na extensão e na precisão das noções gramaticais, apoiadas subsidiariamente nas indicações lexicográficas e na comparação dos manuscritos (LEMERRE, 1874, p. 2, grifo do autor) 


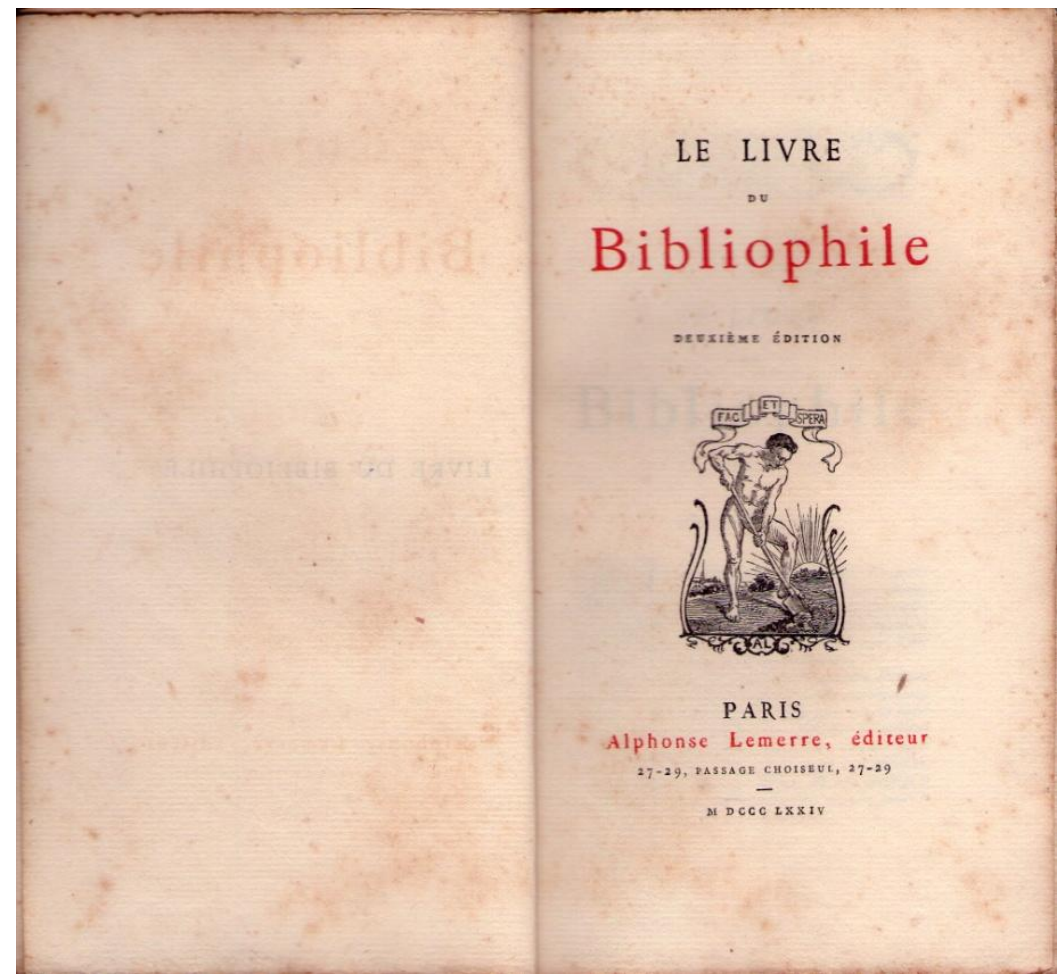

llustr. (48) "Livro do Bibliófilo"

Fonte: LEMERRE, 1874.

Foto: Marcos Corrêa de Mello Felisette

Ainda no capítulo inicial de sua obra, Lemerre (1874) enfatiza o extremo cuidado para com o texto e de como este deveria ser exaustivamente analisado a partir de seu manuscrito. Já vimos também que a problemática do texto está aliada, no que tange a transposição do texto manuscrito para o texto impresso na ordem de sua compreensão léxica. Daí a importância dos editores-impressores quando não eruditos estarem cercados de literatos, o que comprova que uma oficina tipográfica era um espaço envolto deste sentido. Ou seja, um ambiente de construção erudita, de debate e não simplesmente um lugar-tempo de construção técnica do projeto, abstraído de um sentido maior da publicação e por assim ver, de irradiação de cultura.

Assim, por conseguinte, tanto o tipógrafo ou editor detinham naturalmente a compreensão que o seu fazer, dependia do grau e dos limites desta interação. Isto 
é, editar não seria apenas uma tarefa condicionada ao texto em si, como também, a transposição do manuscrito para a impressão não compreenderia uma simples tarefa mecânica do tipógrafo. No seguir desta lógica, o autor nos revela que:

[...] Nosso desejo é de ver exatamente copiados os tipos do século $X V I$. Isso não foi feito até agora. No entanto, não existem tipos mais bonitos do que aqueles utilizados de 1525 a 1600. As artes industriais, ou seja, as artes associadas à vida, floresciam, então, em todo o esplendor de uma expansão única. O belo era algo familiar e acessível a todos os artesãos. O operário sabia dar uma forma soberba tanto a uma letra moldada quanto à grade de um parque ou à lareira de uma grande sala. Durante o Renascimento, a forma das maiúsculas, os itálicos, os contornos do $E$, do $c t$, todas as ligaduras e todas as letras duplas tinham uma beleza posteriormente não reproduzida. (LEMERRE, 1874, pp. 16, 17, grifo do autor)

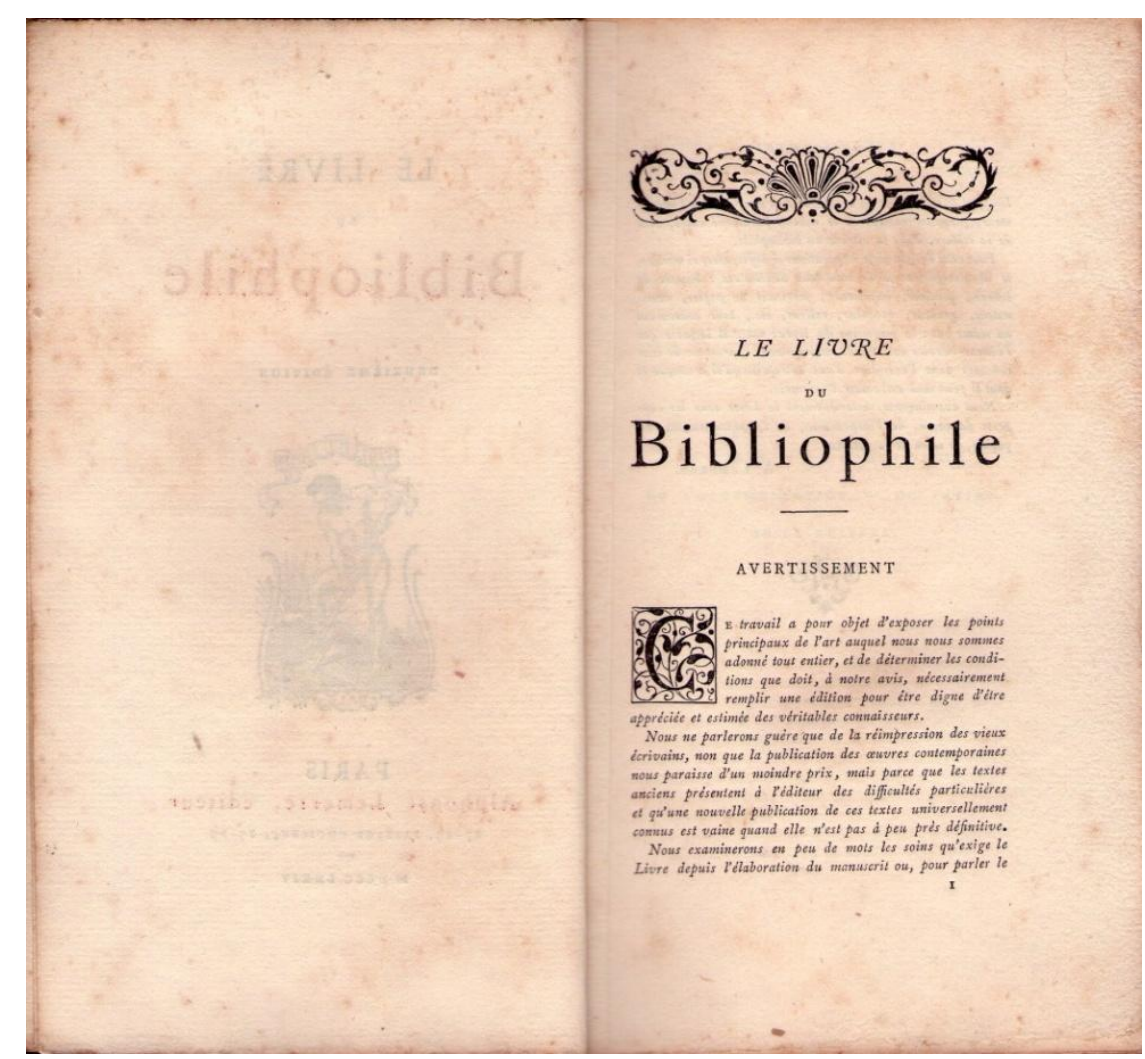

llustr. (49) "Livro do Bibliófilo"

Fonte: LEMERRE, 1874.

Foto: Marcos Corrêa de Mello Felisette 
A tipografia e o projeto editorial também são cuidadosamente estudados, afim de que se traduza o padrão estético e artístico tanto da obra como principalmente do editor diante à sua crença de valores. Ou melhor, da sensibilidade que lhe requeria o pensamento e ação artísticas empenhas em resplandecer o seu intento.

O fazer era o fazer artístico e não cabia nenhuma prática artesanal que apagasse este sentido. O artesão envolto a outras práticas artesanais cujo sentido era o mesmo, cercava-se interinamente no curso desta razão. Ou seja, arte e ciência atrelavam-se ao fazer e atingiram com maestria o paradigma de uma época.

Ao analisarmos as páginas deste livro, no sentido de projeto gráfico, comprovamos de imediato, toda esta organização de valores. Seja pela escolha do tipo, equilíbrio entre a mancha de texto e formato da página; conjugação dos ornamentos ao bloco, capitulares e demais funções de harmonia aos elementos gráficos que denotam ao projeto uma qualidade ímpar.

Fora de questão também, é o primor da impressão enquanto técnica, absolutamente irrepreensível tratando-se de corpos de tipos tão diminutos. O cuidado com a ornamentação teve a mesma leveza e regularidade da mancha de texto, o que confere um profundo conhecimento e domínio da técnica e arte da gravura. Não temos tempo para aprofundarmos esta análise, talvez quem sabe, em um projeto futuro de pesquisa. Ademais, ainda é justo finalizarmos esta citação, com as palavras do autor,

[...] Só fazemos referência no que diz respeito à arte da Renascença e à arte do século XVIII àquilo que é estritamente necessário para indicar a aplicação que delas pode ser feita na decoração dos livros novos. Para nós, que nos ocupamos em particular da reimpressão dos escritores clássicos em caracteres chamados elzevirianos, tivemos de adotar, para os ornamentos, o estilo do século XVI, que é 
o mais próximo ao mesmo tempo da forma tipográfica e do espírito de nossos autores (LEMERRE, 1874, p. 27, grifo do autor)

As obras que completam o estudo da técnica tipográfica e a composição manual, no corpo desta pesquisa, tiveram como critério, em primeiro lugar, exemplificar o posicionamento do tipógrafo frente a seu ofício, assim como foram priorizados os estudos que relacionaram a composição tipográfica com a editoração.

Outras importantes fontes de pesquisa foram analisadas como os manuais técnicos de tipografia elaborados pelo professor Milton Costa (1973 - 1977) e implementadas por Valter José Gonçalves na Escola Senai Theobaldo De Nigris Tecnologia Gráfica; O Manual do Typographo (s/d) editado aqui no Brasil por Francisco Alves e o Manual do Tipógrafo de Ralph W. Polk (1948) adaptado para o ensino técnico em nosso país por António Sodré C. Cardoso.

Também faz parte deste estudo, o Manual de Tecnologia - curso de composição manual, mecanotipia e impressão de Luiz Bernardino (1948) e o manual de ensino tipográfico, La Scuola Tipografica de Félix Luquin, editado na Itália por Gianolio Dalmazzo (1907). Destaca-se também, a obra de Francisco Wlasek Filho, Técnica de Preparação de Originais e Revisão de Provas Tipográficas (1966). 


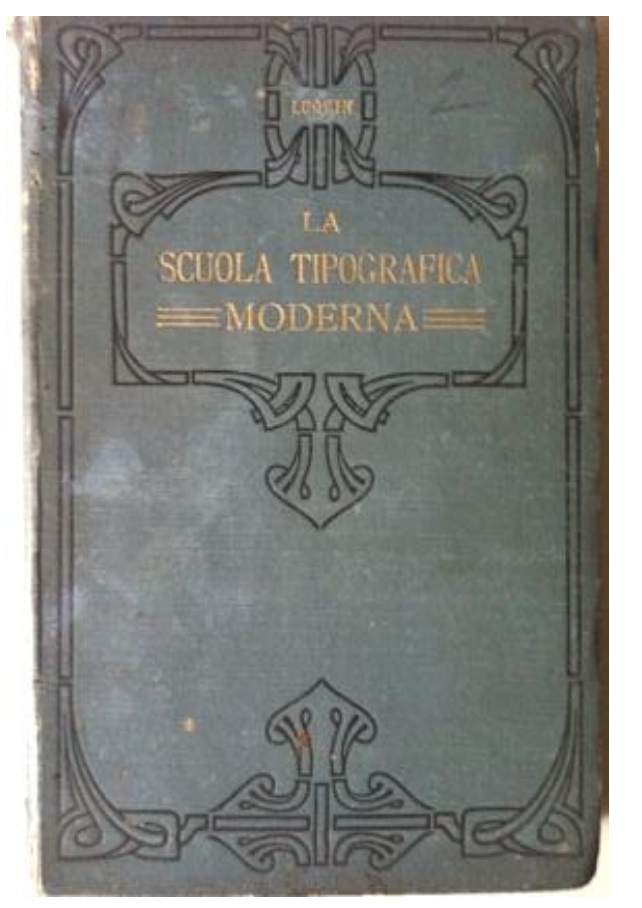

Ilustr. (50) La Scuola Tipografia Moderna Fonte: LUQUIN, 1907.

Foto: Marcos Corrêa de Mello Felisette

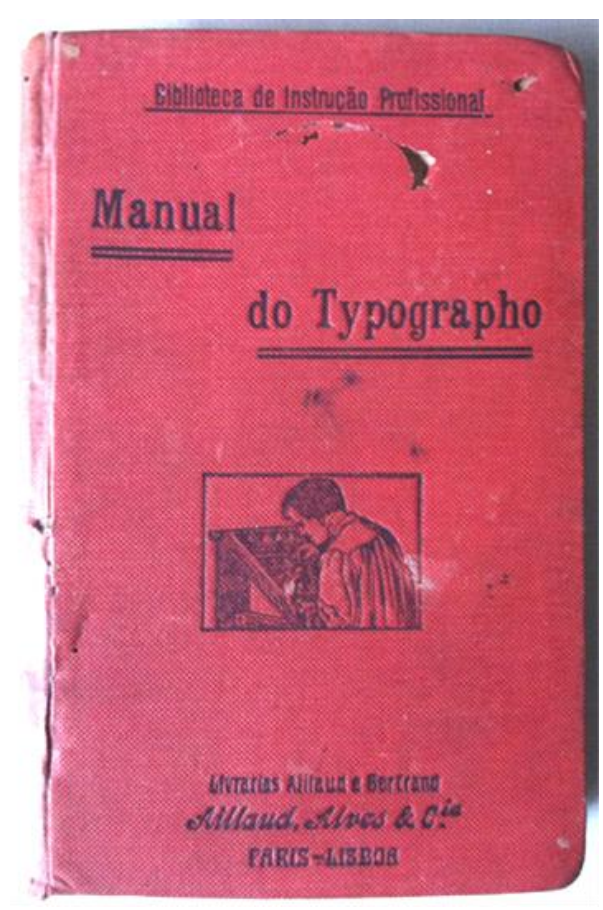

Ilustr. (51) Manual do Typographo Fonte: ALVES, s/d.

Foto: Marcos Corrêa de Mello Felisette

Grande parte deste material tem seu conteúdo voltado ao ensino técnico da tipografia. É claro que os manuais mais antigos possuem uma abordagem um pouco mais ampla e diferenciada quanto às práticas tipográficas e sua história, fato a se fazer notar nos manuais recentes onde a ênfase concentra-se nos modos operacionais e técnicos, bem como na parte de mecânica.

Outro dado relevante é sobre as normatizações quanto às composições de texto, revisão, emendas e todo o preparo da composição na sua parte de editoração. Nos chama atenção o grau de complexidade das diversas etapas em que o tipógrafo deveria despender com o texto. Variações de composição são apresentadas como também, orientações combinatórias entre estilo de texto e estilo tipográfico. 
A composição em si, obedece toda uma fundamentação teórica para o trabalho com os tipos móveis e o seu sistema. Também sugere um preparo de raciocínio para o tipógrafo adequar suas composições a uma variação de impressos além dos livros (cartões de visita, talonários, panfletos etc.).

Deste modo, vemos claramente o lado técnico sobrepor algum respiro artístico, a criatividade, a partir de então, é destinada aos percalços da profissão. Isto é, saber lidar com os problemas técnicos e operacionais, no intuito de uma boa qualidade de impressão, era tido como meta para os cursos de formação técnica na época (final da década de 1960). Assim, a maioria destas apostilas de ensino contêm uma sistematização de ensino, divididas por etapas no intuito de uma boa didática para o aprendizado.

Quanto às famílias tipográficas, os catálogos de fontes da Escola Senai Theobaldo de Nigris, acompanhavam o que dispunha o mercado e sua variação para a composição dos impressos. Relacionamos abaixo algumas das principais fontes encontradas:

- Kabel Normal Especial (corpos 6 à 48 pontos)

- Kabel Meio Preto (corpos 6 à 48 pontos)

- Kabel Grifo Normal Claro (corpos 6 à 48 pontos)

- Grotesca Normal Clara (corpos 6 à 48 pontos)

- Grotesca Reforma Meia Preta Largura Normal (corpos 6 à 48 pontos)

- Grotesca Normal Meia Preta (corpos 6 à 48 pontos)

- Grotesca Normal Meia Preta Estreita (corpos 6 à 48 pontos)

- Grotesca Reforma Gorda Apertada (corpos 6 à 48 pontos)

- Grotesca Larga Clara (corpos 6 à 36 pontos)

- Grotesca Larga Meia Preta (corpos 4/6 à 36 pontos) 
- Vitória - Grotesca Preta (corpos 8 à 60 pontos)

- Antiga Medieval (corpos 6 à 48 pontos)

- Garamond (corpos 16 à 48 pontos)

- Guanabara (corpos 6 à 60 pontos)

- Mondial Magro (corpos 6 à 48 pontos)

- Mondial Magro Grifo (corpos 6 à 36 pontos)

- Antiga Salão (corpos 4/6 à 20 pontos)

- Memphis Magro (corpos 6 à 48 pontos)

- Memphis Magro Grifo (corpos 6 à 48 pontos)

- Egiptienne Claro (corpos 6 à 36 pontos)

- Rio Branco (corpos 8 à 48 pontos)

- Bravour Meia Preta (corpos 6 à 72 pontos)

- Alegro (corpos 12 à 96 pontos)

- Eldorado Claro (corpos 10 à 48 pontos)

- Gladiola (corpos 12 à 48 pontos)

- Arcona (corpos 10 à 48 pontos)

- Rondo (corpos 10 à 60 pontos)

- Vette - Rondo (corpos 6 à 48 pontos)

- Studio (corpos 8 à 72 pontos)

Compõem ainda o acervo disponível na época uma gama de vinhetas, fios de latão, numeração sistemática, capitulares e tipos de madeira encontrados nos corpos $96,120,132,144,168,192,312,360$ e 480 pontos. As duas principais distribuidoras de tipos (Fundidoras) na época, eram as empresas Manig e Funtimod. 
Existe uma grande lacuna na história da tipografia no Brasil quanto à fundição de tipos. Em tempo, alguns pesquisadores estão se aprofundando no assunto e, com toda certeza, poderão contribuir com a memória gráfica de nosso país.

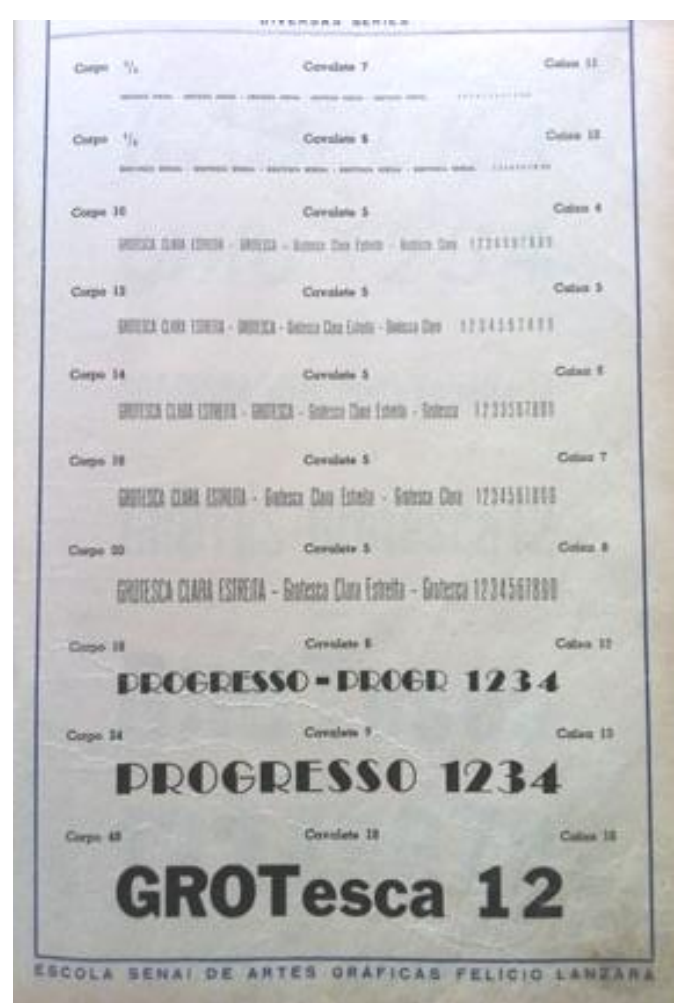

llustr. (52) Catálogo de tipos, 1970.

Fonte: Senai Artes Gráficas

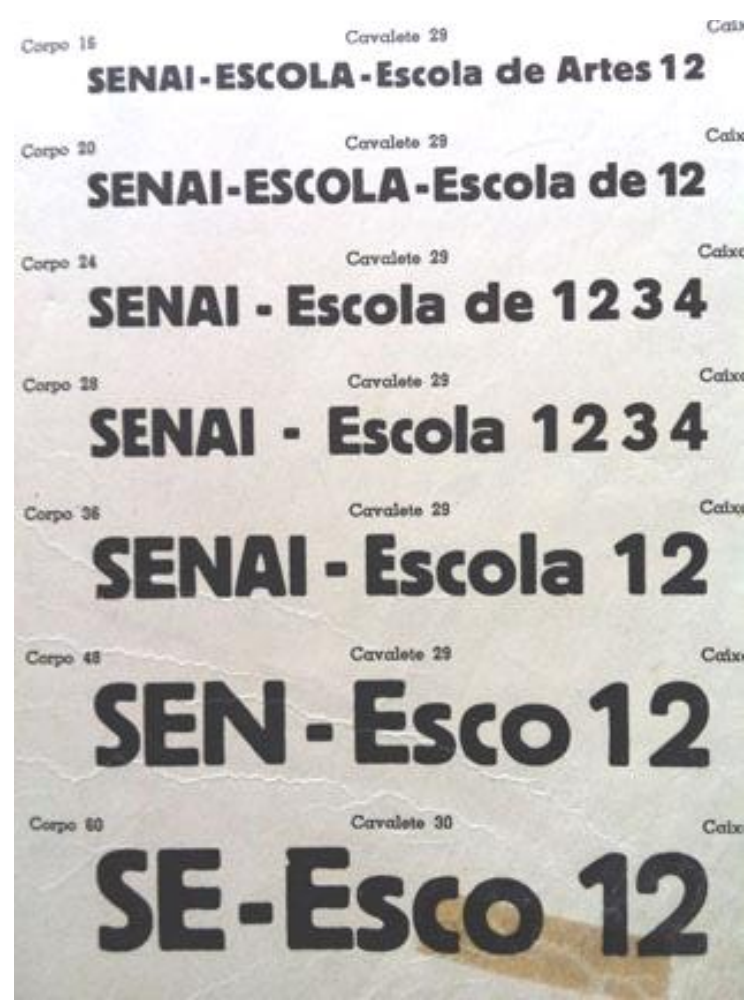

Ilustr. (53) Catálogo de tipos, 1970.

Fonte: Senai Artes Gráficas 


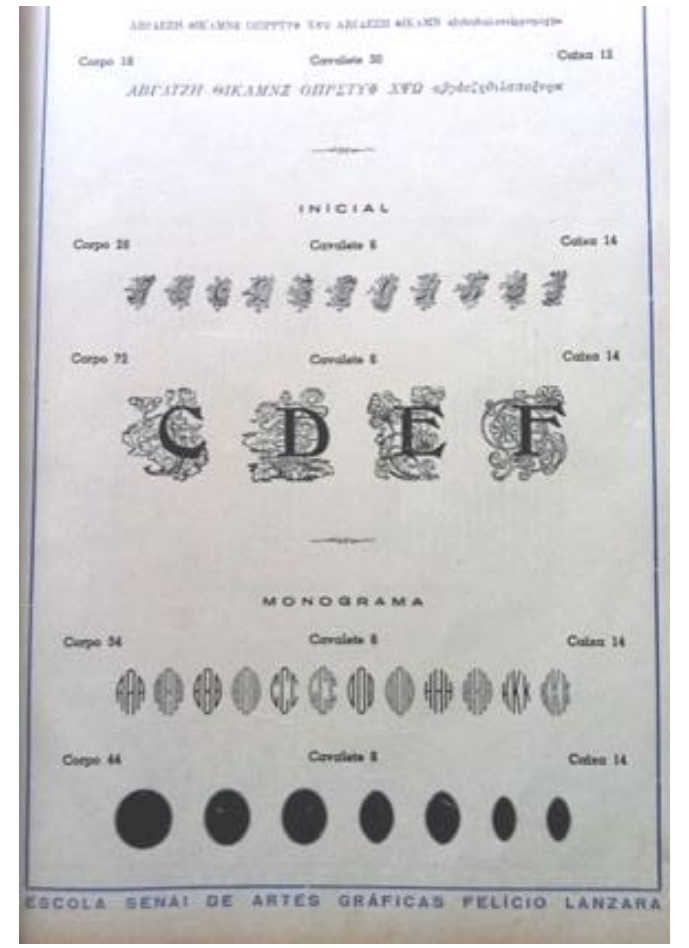

Ilustr. (54) Catálogo de tipos, 1970.

Fonte: Senai Artes Gráficas

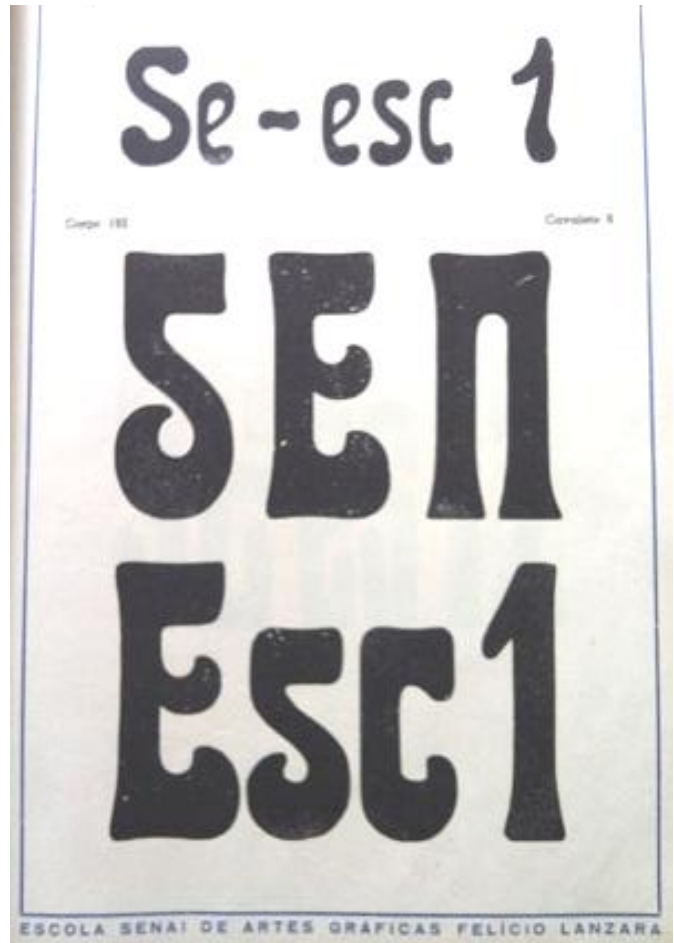

Ilustr. (55) Catálogo de tipos, 1970.

Fonte: Senai Artes Gráficas 


\section{A OFICINA TIPOGRÁFICA: O MEIO DE PRODUÇÃO COMO MEIO}

\section{DE LINGUAGEM}

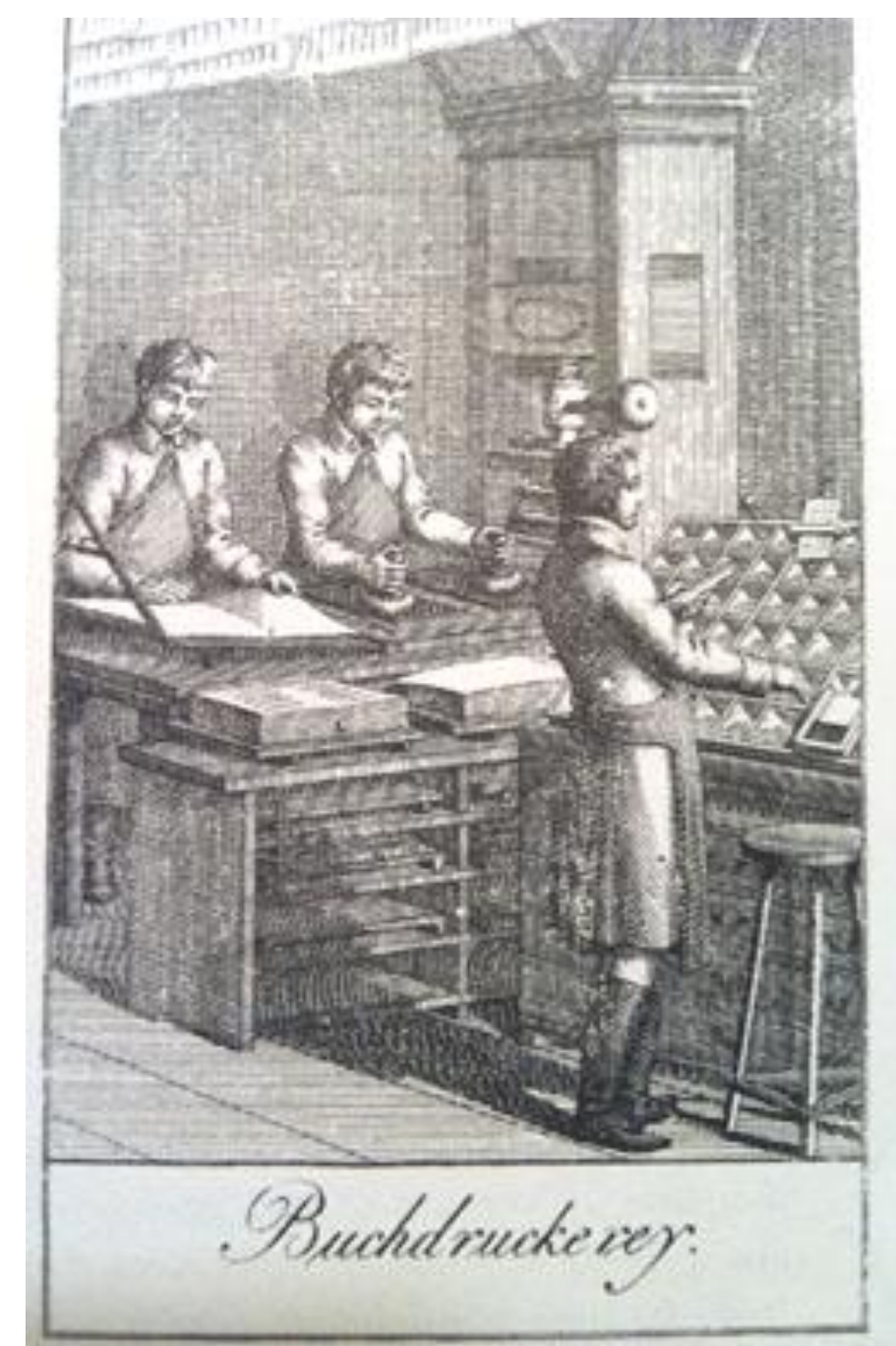

Ilustr. (56) Compositor com caixa de tipos, componedor e galé.

Gravura de Taubel, 1810

Fonte: GAUDÊNCIO JÚNIOR, 2004, p. 37.

Desde o início, a tipografia teve como grande particularidade o seu meio de produção. O livro impresso é a melhor tradução do que veio a se originar a partir daquele ambiente dotado de ciência e arte. Isto é, as oficinas tipográficas a partir de sua expansão pela Europa nos finais do século XV, respiravam o ar misterioso e de alquimia do seu fazer. 
Por outro lado, vimos que com a possibilidade de expansão do comércio livreiro, as oficinas se empenharam na otimização de seus negócios e para tanto, aperfeiçoaram seu regimento de trabalho. $O$ fato é que nunca deixaremos de enxergar a posição de uma oficina tipográfica enquanto centro de expansão e local de fomento cultural.

Vimos que a condição de trabalho para aquele que editava estava muito próximo ao que compunha e imprimia. Editores-tipógrafos-impressores eram muito comuns e não fugia muito à regra, serem pessoas eruditas e neste sentido, agentes culturais à serviço de seu tempo na expansão da informação.

Vimos, também, que a princípio o tipógrafo assumia o papel de criador e também de co-autor das obras. Sua participação neste processo de construção do livro se deu em um ambiente aquecido de ideias onde pensar, projetar e executar ocupavam o mesmo espaço.

Não é a toa que podemos recorrer na história da imprensa e verificar uma série de oficinas cujo ambiente é literalmente o que aqui se descreve. Portanto, a oficina tipográfica enquanto lugar-tempo, exerceu importante papel no cenário sócio político cultural em cada cultura que se manteve estabelecida.

Não é necessário estabelecer aqui todo um panorama das oficinas tipográficas espalhadas pelo mundo e as contribuições que estas prestaram às suas culturas. A exemplo disso, podemos apenas citar a obra de Robert Darnton e Daniel Roche (1996), Revolução Impressa - A Imprensa na França, 1775 - 1800, que explora a questão. Como aponta o autor,

[...] o quanto, afinal, podemos saber sobre a oficina no final do século XVIII? Está instalada numa casa de moradia comum, mal adaptada aos imperativos técnicos da produção: de um jeito ou de 
outro as caixas de tipos têm que estar instaladas, juntos com os prelos, um depósito para o papel, um tanque para umedecer o papel, um cubículo para o mestre, possivelmente uma sala de secagem (o papel era impresso úmido) e uma loja, porque os impressores eram em sua maioria também livreiros (DARTON; ROCHE, 1996, p. 158)

Dentro deste ambiente, ao que tudo indica, destinava-se uma "sala para a composição", lugar onde provavelmente o editor exercia suas funções junto ao tipógrafo na parte de texto. Mas o fato, como nos aponta Darnton (1996), as oficina tipográficas nunca seguiam a regra descrita em seus manuais. Dependendo do que se propunham a imprimir, as configurações de espaço e mobiliário modificavam-se mas mantinham um padrão comum para as tarefas de fundição, composição, impressão e acabamento.

Uma oficina tipográfica pode ser facilmente entendida pelo seu mobiliário e não por aquilo que está composto. Isto é, os materiais e sua disposição deflagram a dinâmica que estabelece-se no seu próprio sistema: compor/construir - imprimir desconstruir/distribuir.

São três as funções primárias na divisão de trabalho de uma oficina: compor, imprimir e distribuir (guardar os materiais em seus devidos compartimentos). Como apontamos, as configurações de espaço pode mudar de acordo com a oficina e propósito a que se destina. Mas a regra é única a todas: não há trabalho que possa ser realizado com o "empastelamento" ${ }^{26}$ das caixas de tipos ou com uma bagunça generalizada de seus materiais.

\footnotetext{
26 "Empastelar" no vocabulário dos tipógrafos significa bagunçar ou misturar. Quando se diz que uma caixa de tipos está "empastelada", significa que os tipos estão em ordem alterada quanto à sua disposição na mesma. A prática de empastelar uma tipografia também se deu por ordem dos governantes como forma de repressão à liberdade de imprensa.
} 
Vemos na história, como apontam pesquisadores do livro impresso, que as tipografias eram ligadas à pequenas lojas ou boticas. Obviamente porque a atividade livreira sempre requereu um fim. Mas o curioso é que encontramos outro sentido neste espaço, o que por nós já foi esboçado, mas que torna-se claro quando pensamos que este espaço era um ponto de encontro. Era um local para a reunião de escritores, poetas e artistas, cuja proximidade ao seu cerne, delineva as particularidades deste lugar-tempo na condição de seu fazer.

O produto impresso por esta via, resplandecia as condições que the eram impostas à sua criação. No Brasil do século XIX, temos como grande exemplo, a figura de Francisco de Paula Brito, tipógrafo-livreiro, preterido pela elite intelectual do Rio de Janeiro. Concentrou esforços para o "leitor comum" e segundo Hallewell (2005. p. 159), "[...] foi praticamente o primeiro editor não-especializado genuíno do país, citado por Machado de Assis". Sua oficina, a "Imperial Typographia Dous de Dezembro" foi centro do grande impulso à literatura brasileira, praticamente inexistente na década de 1840. Nas palavras do autor,

Paula Brito não apenas editava; foi também o primeiro editor a assumir o risco de publicar obras de literatos brasileiros contemporâneos por sua própria conta, em vez de fazê-lo por conta do autor, como uma estrita transação comercial [...] Pela primeira vez, um poeta ou um romancista nacional poderia almejar ser publicado em livro e ser pago por isso (HALLEWELL, 2005, p. 161, grifo do autor)

Outros exemplos despontam com a mesma coragem e perspicácia da qual foi o tipógrafo-editor Francisco de Paula Brito e sua oficina tipográfica. Estas oficinas, no século XIX, iniciaram um árduo trabalho não apenas à questão da publicação e impressão em si, mas no profundo sentido de comprometimento à literatura 
brasileira. Acolheram autores, poetas e artistas. Juntos, personalizaram edições e marcaram época na construção de nossa história editorial.

Tal estudo possui obras de fôlego e execelência em pesquisa, como é o caso do citado Livro no Brasil de Laurence Hallewell. Nos dão luz à uma época ainda remota na publicação e comercialização dos livros no Brasil e nos ajudam a desvendar o feitio gráfico editorial e seu modo de construção em nossa cultura.

As particularizações do projeto gráfico editorial brasileiro nos apontam duas vertentes iniciais quanto às suas características. A primeira, com ênfase no emprego e na adaptação dos padrões tipográficos europeus à nossa cultura, como é o caso dos livros impressos pelo tipógrafo editor Francisco de Paula Brito ainda no século XIX; e a segunda, que vai de encontro à vertente dos impressos ilustrados aos finais do mesmo século e início do século XIX. Rafael Cardoso (2005) nos aponta que:

[...] se é verdade que o Brasil-Colônia tardou muito a integrar-se ao circuito de produção e consumo de livros que marcou a Europa entre os séculos XVI e XVIII, é igualmente verdadeiro que o Brasil-Império ingressou praticamente ao mesmo tempo que a Europa e os Estados Unidos no novo regime industrial de comunicação visual por meio dos impressos ilustrados, pois é notório que a litografia e a fotografia foram introduzidas no Brasil em virtual simultaneidade à sua disseminação no resto do mundo [...] no que tange à produção de livros com capas ilustradas, o caso brasileiro é surpreendente tanto pelo pioneirismo como pela originalidade [...] É sobretudo na década de 1920, e em especial em países de menor tradição tipográfica, como os Estados Unidos e o Brasil, que surge uma cultura forte de ilustração de capas [...] há um senso comum de que teria sido Monteiro Lobato o primeiro editor a romper com o padrão vigente de capas puramente tipográficas (CARDOSO, 2005, pp. 164 - 165) 
Não é difícil compreeender neste sentido, o curso dos projetos editorias nas tipografias e gráficas que se espalhavam pelo Brasil. Também fica mais nítido a aproximação destes artistas gráficos ao corpo editorial moldando o aspecto estético do livro a partir de então.

Cabe enfatizar que, ao aproximar os artistas, escritores e poetas no espaço de construção do projeto, criou-se todo um ambiente fecundo e particularizador ao nosso impresso. Prova física destas palavras se reserva a história que nos conta a rua do Ouvidor $^{27}$ no Rio de Janeiro, ponto de encontro literário e das oficinas tipográficas que se concentravam junto a outros estabelecimentos artísticos comerciais nos idos dos anos 1920.

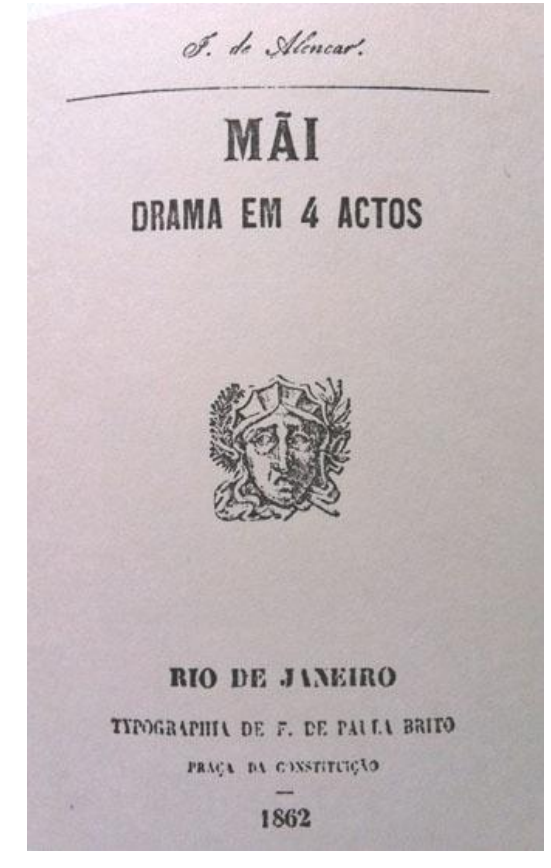

llustr. (57) Capa de Paula Brito

Fonte: SEMERARO; AYROSA, 1979, p. 98

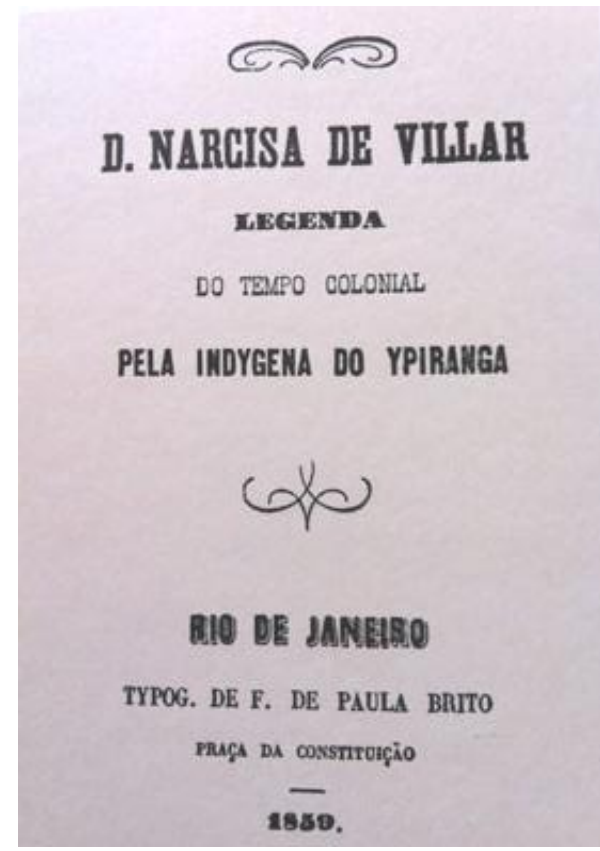

llustr. (58) Capa de Paula Brito

Fonte: SEMERARO; AYROSA, 1979, p. 99

${ }^{27}$ A rua do Ouvidor é tema da Obra de Joaquim Manoel de Macedo, Memórias da Rua do Ouvidor, cuja primeira edição data de 1878 publicada pela Garnier. 


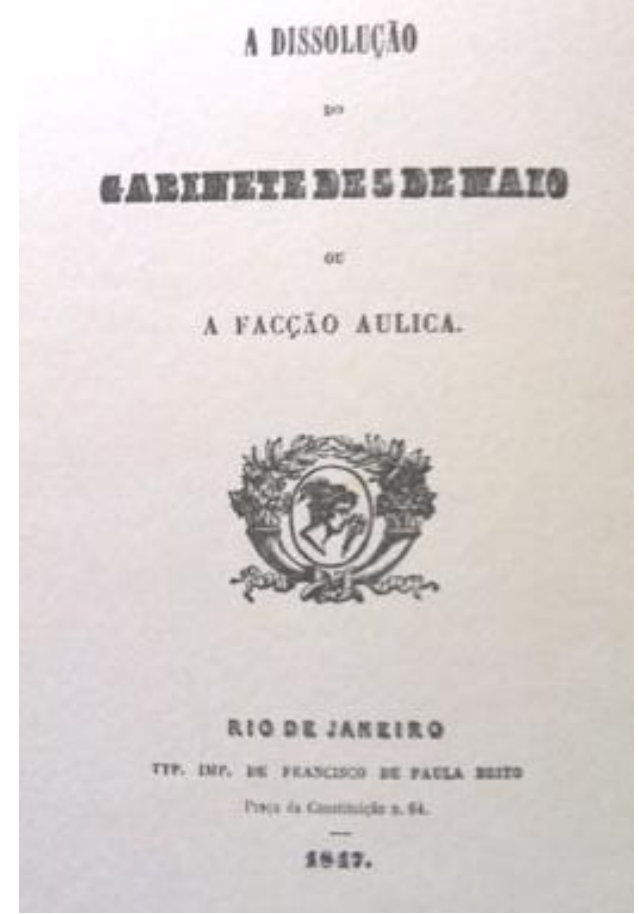

llustr. (59) Capa de Paula Brito

Fonte: SEMERARO; AYROSA, 1979, p. 96

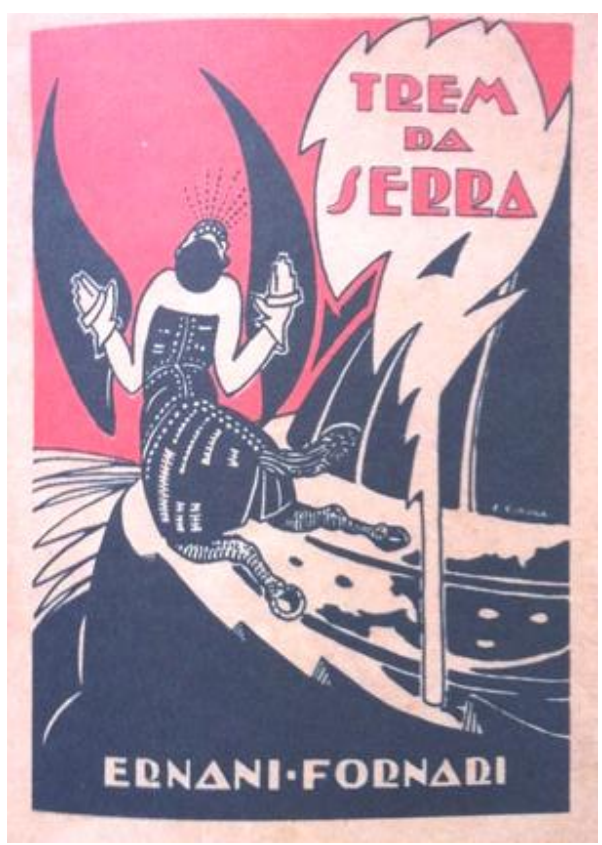

llustr. (60) Capa de Fernando Corona Um dos primeiros livros editados pela Livraria do Globo, 1928

Fonte: CARDOSO, 2005, p. 167.

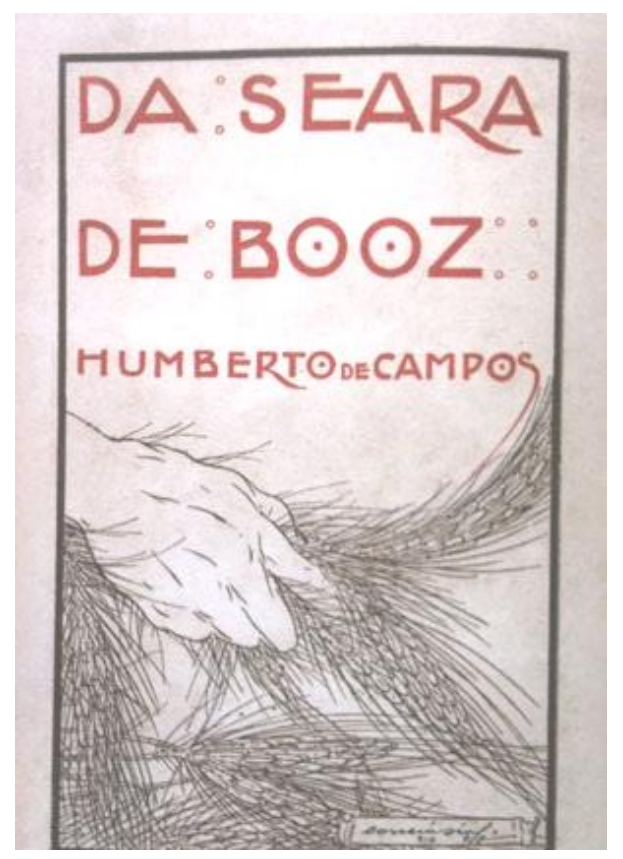

Ilustr. (61) Capa de Fernando Correia Dias para a Editora Leite Ribeiro, 1918. Fonte: CARDOSO, 2005, p. 166. 


\section{O GRÁFICO AMADOR COMO EXPERIMENTAÇÃO EDITORIAL}

O Gráfico Amador foi, sem dúvida alguma, na vida de Aloisio Magalhães, o período em que ele teve a oportunidade de dar grande vazão ao seu repertório e talento gráfico com o intento de projetar livros. Não que após esta fase (de 1954 1961) ele tenha deixado de fazê-lo. Pelo contrário, o trajeto de sua vida como artista sempre se caracterizou pelo contínuo processo de questionamento e mudança frente a linguagem pela qual se expressava.

A experiência n'O Gráfico Amador foi ímpar no sentido de atelier editorial. Sim, podemos nos referir a este projeto neste sentido, pela simples razão de se configurar como uma pequena gráfica artesanal nos moldes das chamadas "private press" $^{\prime 28}$, a exemplo de William Morris na Inglaterra, em meados do século XIX. A partir disso, entende-se também, quando reportado ao Brasil, mais propriamente à cidade de Recife na década de 1950, o vulto de tal trabalho.

Se a bossa nova teve um similar no campo das artes gráficas, este é $O$ Gráfico Amador. Como já é de conhecimento para os amantes e não somente aos pesquisadores da área gráfica, Guilherme Cunha Lima (1997) em seu livro, O Gráfico Amador, as origens da moderna tipografia brasileira, nos traz as palavras do grupo em seu Noticiário 1:

O Gráfico Amador reúne um grupo de pessoas interessadas na arte do livro. Fundado em maio de 1954, tem a finalidade de editar, sob cuidadosa forma gráfica, textos literários cuja extensão não ultrapasse as limitações de uma oficina de amadores. Os trabalhos são projetados e realizados por Aloisio Magalhães, Gastão de

\footnotetext{
${ }^{28}$ A respeito destas pequenas gráficas ver: private press movement e Kelmscott Press de William Morris, Inglaterra, 1891.
} 
Holanda, José Laurenio de Melo e Orlando da Costa Ferreira (O Gráfico Amador, 1955 apud LIMA, 1997)

Este grupo de pessoas "interessadas na arte do livro", como nos diz o boletim, possuia uma configuração interna muito peculiar. Dividiam-se em duas categorias: os chamados "mãos sujas" que literalmente sujavam as mãos por estarem em contato com as tintas no processo de confecção dos livros, e os chamados "mãos limpas”. Estes últimos, eram escritores, poetas, colecionadores e demais membros pertencentes a tal sociedade.

Contribuiam financeiramente com O Gráfico Amador recebendo em troca um exemplar daquilo que o grupo se propunha a editar. Desta forma, O Gráfico Amador coordenava um minucioso trabalho gráfico tanto nos projetos como na execução de seus livros.

A criação era conjunta, fluia dentro daquele espaço com a contribuição de todos. É claro que ocorriam alternâncias nos papéis de cada um sobre a direção e argumentação do projeto, mas somavam-se as experiências individuais em prol da criação coletiva. O individual não se sobressaía ao coletivo, e isto fazia parte do modo como o projeto era pensado, criado e gerido. Isto é, ele acontecia lá dentro como fomento da experiência de atelier, de laboratório.

Guilherme Cunha Lima relata em um artigo, O Lúdico e o Informal $^{29}$, esta característica do grupo enquanto uma metodologia de trabalho. Segundo Lima (2000), era lúdico e informal mas nem por isso deixava de ser rigoroso.

\footnotetext{
${ }^{29}$ Este artigo foi escrito por Guilherme Cunha Lima para o boletim da ADG a partir de uma entrevista realiza com Aloisio Magalhães. Ver em LIMA, Guilherme Cunha. O lúdico e o informal. In: Revista ADG. São Paulo: ADG, n.19, mar. 2000, p. $22-24$.
} 
Ao analisarmos algumas das principais obras do grupo, vemos um grande refinamento, uma preocupação com os detalhes e de como o trabalho em seu todo, era bem conjugado no ponto de vista da linguagem gráfica. Tanto o trabalho verbal como o não verbal, isto é, texto e imagem, complementam-se num rico e convidativo discurso. Nada de exageros, e sim, uma sutileza na disposição e nos pesos dos elementos gráficos, que por este curso, empregam um ritmo de linguagem muito agradável por onde a poesia é enrrigada.

Ao que tudo indica - e se comprova pelas obras - o grupo mantinha um compasso de trabalho que possibilitava as pequenas descobertas. Isto se deu não somente devido à reunião dos artistas e intelectuais mas também, e fundamentalmente, pelo que discutimos enquanto lugar-tempo no processo de criação e execução do objeto gráfico.

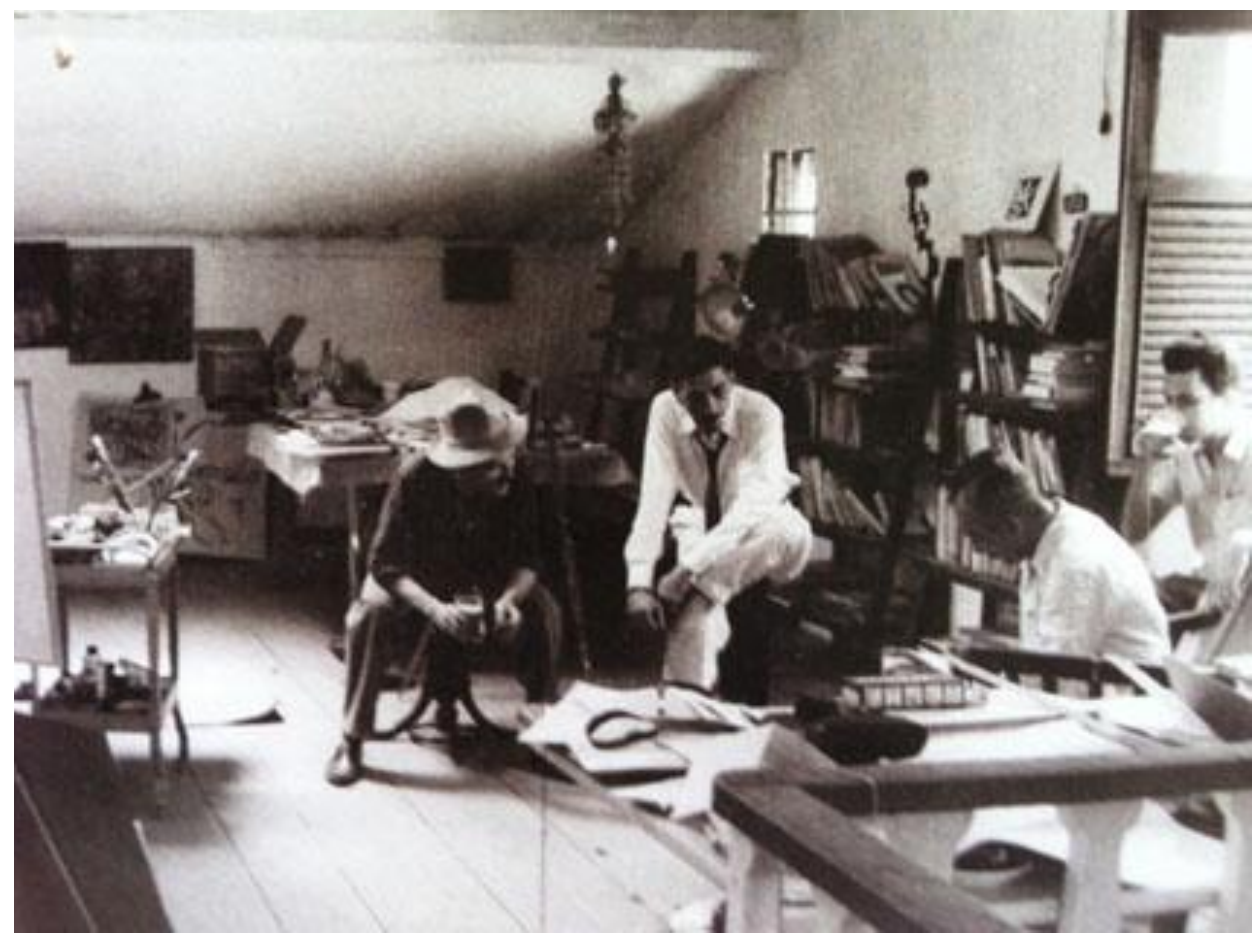

Ilustr. (62) Aloisio (de chapéu), José Laurenio de Melo, Orlando Ferreira (lendo) e Abel Accioly (sentado no peitoril da janela), no atelier no sótão da Rua Amélia. Fonte: LEITE, 2003, p. 44 
O trabalho do grupo era realizado duas vezes por semana, sempre à noite, e isto Ihes dava uma condição especial para o refinamento daquilo que estava se criando e produzindo. Cada detalhe era pensado e amadurecia em seu tempo, para o melhor conjunto da obra, desde a escolha dos tipos à ilustração.

$\mathrm{Na}$ análise da linguagem gráfica de Aloisio Magalhães que será realizada no terceiro capítulo encontram-se detalhadas as técnicas utilizadas pelo grupo para as ilustrações e que fazem parte do processo de construção de linguagem d'O Gráfico Amador.

Desse ponto de vista, percebe-se que a ilustração servia-se de um repertório que abrangia uma certa diversidade de técnicas, mas que também lidava com os limites de sua produção e da disponibilidade de material que havia. $\mathrm{E}$ isso se estendia ao projeto em si, ou seja, número de páginas da obra/ tiragem, entradas de cor, planejamento de capa, entre outros. Havia com certeza o fator de superação frente ao limitador, velho conhecido de toda força criativa, que esteve presente no trabalho do grupo.

Isso porque, observa-se que a beleza destes trabalhos também provinha do carater de experimento artesanal, com técnicas adaptadas ao passo do momento. Havia muita intervenção manual dentro do processo linguístico do grupo. E aí centrase a questão do trabalho gráfico de Aloisio Magalhães frente ao projeto editorial. Ou seja, a construção do projeto estava ligada ao próprio fazer, nascia e amadurecia a partir do seu transcorrer. Tanto que $O$ Gráfico Amador deu continuidade neste sentido, àquilo que ele fazia com a pintura, a gravura. Era o modo como ele concebia e representava a ideia gráfica.

A experiência com grupo, nesse pensar, era a continuidade de um processo que ele carregava consigo, algo que ia se desdobrando em seguidos movimentos. 
Aloisio Magalhães propunha em seus trabalhos o próprio debate do fazer gráfico. E isso era uma prática comum do grupo que junto formou O Gráfico Amador.

O Gráfico Amador não era, portanto, uma editora comum. Muito menos uma tipografia com prática usual. Caracterizava-se como uma sociedade de intelectuais que alugaram uma casa, muniram-se de equipamentos e trabalharam coletivamente durante cerca de oito anos em prol de um ideal: editar textos literários sob cuidadosa forma gráfica.

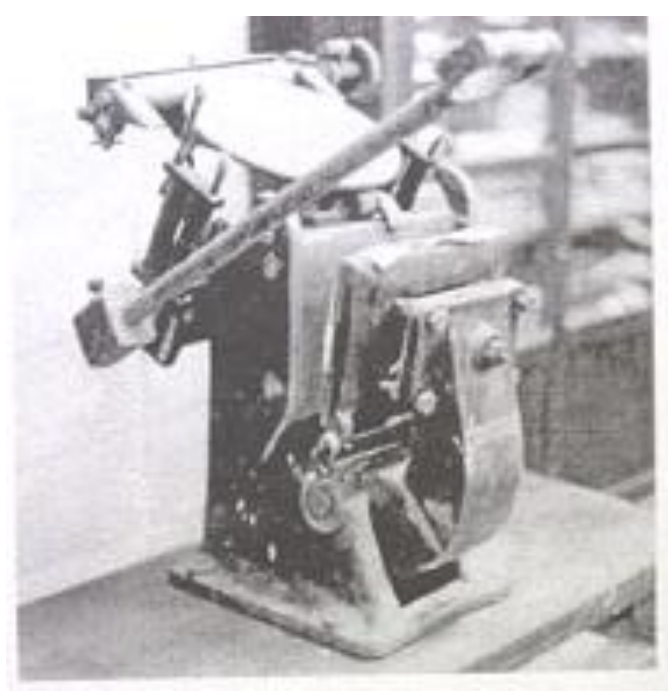

Ilustr. (63) Primeira impressora tipográfica d'O Gráfico Amador

Fonte: LIMA, 1997, p. 130.

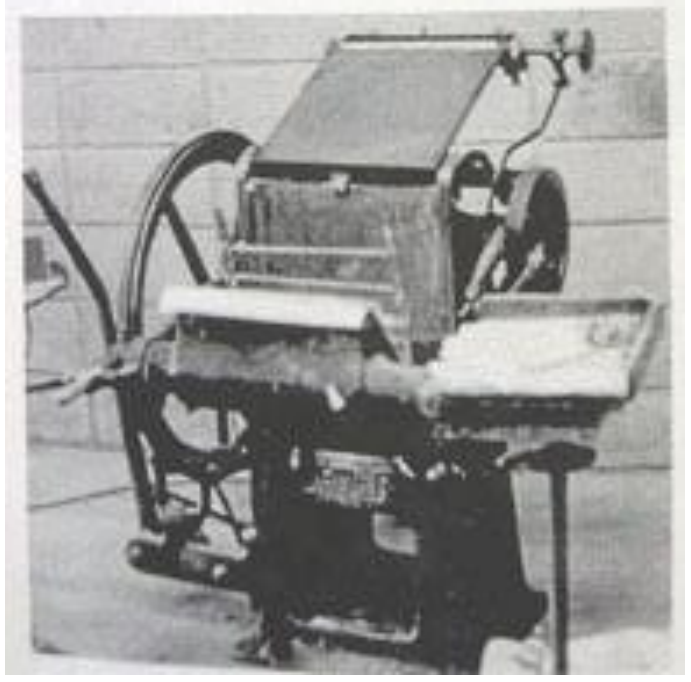

Ilustr. (64) Segunda impressora tipográfica d'O Gráfico Amador Fonte: LIMA, 1997, p. 130. 


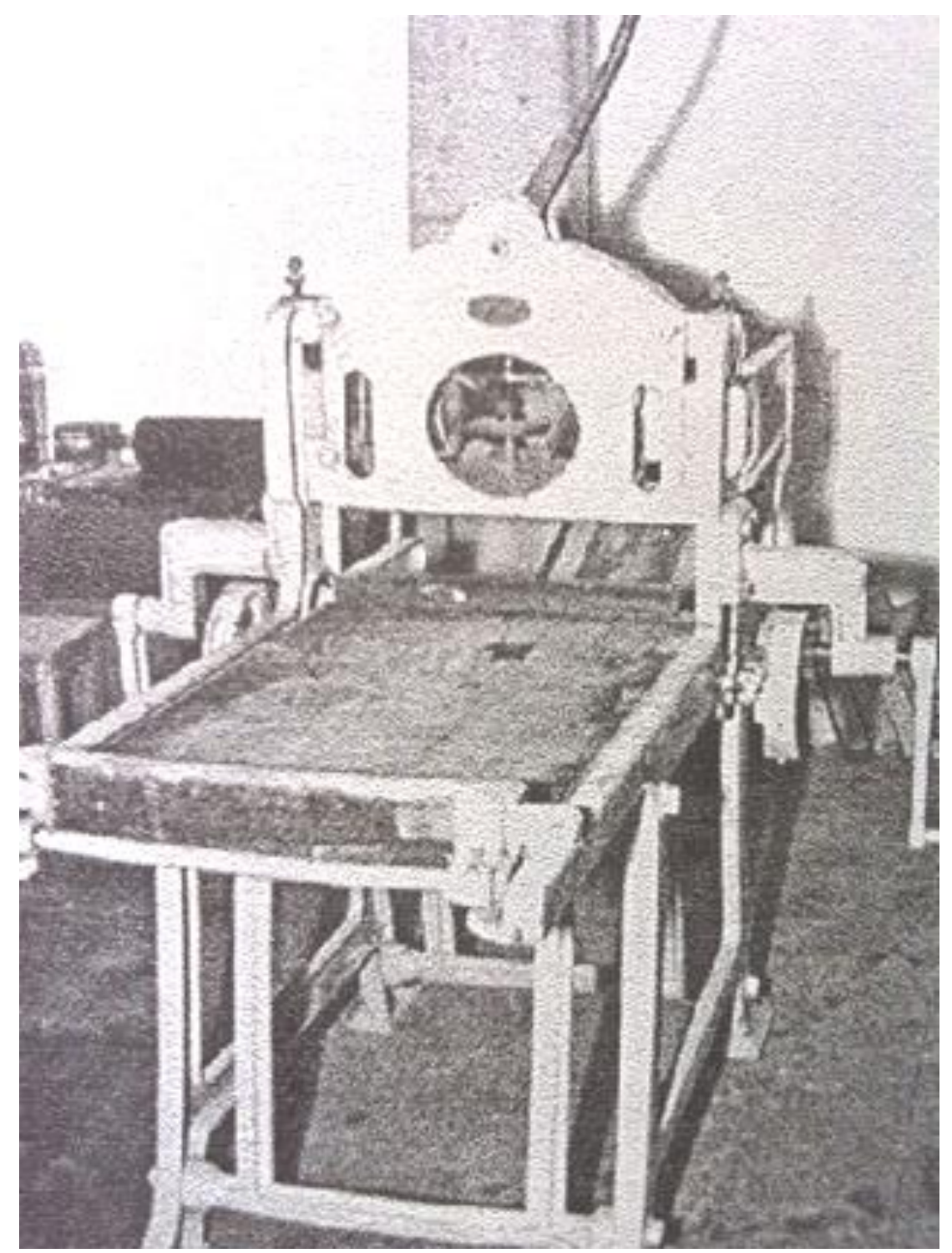

Ilustr. (65) Impressora litográfica Karl Krause Leipzig, ㄲo 17133 d'O Gráfico Amador

Fonte: LIMA, 1997, p. 131.

Ao que tudo indica, este espaço-tempo, caracterizou-se como uma grande escola à todos que ali participaram. Foi um momento de discutir de perto possibilidades na edição de livros fora do eixo das grandes editoras que se concentravam entre Rio de Janeiro e São Paulo. A possibilidade em si, estava embuída na experimentação gráfica. Daí o caráter realmente de escola, pois foi a partir disso, desta oportunidade, que Aloisio Magalhães aprendeu a projetar um livro 
e mais tarde encaminhou-se para o design. Foi no fazer, nas tentativas, na discussão do projeto.

O Gráfico Amador, construiu à sua maneira, o modo de se pensar e executar o projeto gráfico, agregando a experiência de seus componetes com a vivência coletiva da qual participavam. Por lá estiveram Ariano Suassuna, João Cabral de Melo Neto, Mauro Mota, Hermilo Borba Filho, entre tantos outros intelectuais da época.

O costume de se reunir e debater os textos, bem como sua forma gráfica, foi uma projeção natural do que o núcleo destes artistas e escritores havia vivenciado anos antes no TEP. Talvez de um modo indireto para alguns, o fato é que sentiramse atraído de alguma maneira à este movimento intelectual. Segundo José Laurenio de Melo,

[...] esse Teatro do Estudante de Pernambuco era a nova versão do que surgia no Recife ainda no final da década de 1930 - versão implementada em 1943 pelo fundador da Campanha do Ginasiano Pobre, o estudante Felipe Tiago Gomes [...] No formato definitivo que the deu Hermilo Borba Filho, o TEP foi relançado em abril de 1946 [...] formado por estudantes predominantemente de direito reunidos em torno de Hermilo (este e Gastão de Holanda, mais velhos do que o restante do grupo, já eram nomes de prestígio nas rodas literárias do Recife), o TEP iria ter um papel decisivo na renovação das artes cênicas do Nordeste e não tardaria a assumir as características de um movimento intelectual nucleado no teatro mas com forte influxo sobre todas as áreas da criação artística (LAURENIO DE MELO in LEITE, 2003, p. 31 - 32)

O Gráfico Amador, pela sua formação e o modo com que desenvolvia seus trabalhos, estabeleceu uma estreita ligação entre a poesia, as artes gráficas e o livro. Não havia uma divisão neste sentido entre quem era o editor, o escritor, o 
artista gráfico e o impressor. Os papéis misturavam-se no trabalho coletivo do grupo, e assim desenvolvia-se tanto o projeto como o seu produto.

O "cuidado com a forma gráfica" citada no Boletim 1 pelo grupo, se detinha à concepção de algo, ao refinamento de toda ideia gráfica a ser criada a partir de um projeto. Ou seja, a linguagem gráfica partia da compreensão daquilo que estavam editando, ao contrário de uma regra ou estética pré concebida. E isso não deve ser confundido com uma total ausência de metodologia, mas sim na atenção às particularidades de cada projeto, no entendimento de que a "forma gráfica" é resposta do seu conteúdo.

A experiência d'O Gráfico Amador foi motivada pela iniciativa de seus participantes, mas principalmente pelo encorajamento do poeta João Cabral de Melo Neto. Foi dele a sugestão dada ao grupo, para que comprassem o maquinário e se dispussessem a editar os livros.

João Cabral De Melo Neto sabia compor em tipografia e possuia uma prensa particular na Espanha por onde imprimia e editava seus livros inconsúteis - assim eram chamados os livros que não eram costurados. Além disso, Aloisio Magalhães era primo do referido poeta e foi pelas suas mãos que a técnica da composição foi aprendida. Observa-se claramente esta influência estampada nas primeiras composições do grupo.

A exemplo de João Cabral de Melo Neto, vemos outros escritores e poetas que editavam e imprimiam por conta própria diante às circunstâncias do mercado. É o caso de Vicente do Rego Monteiro, que também possuia uma gráfica em Pernambuco e, um pouco mais distanciado pelo tempo, no século XIX, Tobias Barreto, escritor e filósofo brasileiro. Sabemos também do envolvimento de Gilberto 
Freyre com a questão da publicação de livros no Nordeste, mas o momento não nos reserva ao assunto.

O fato é que, por esta análise do projeto d'O Gráfico Amador, nos cercamos de um perfil diferenciado no que tange a edição e impressão de livros na década de 1950 no Brasil. A experiência d'O Gráfico Amador revela uma singularidade quanto às edições de livros com um tratamento diferenciado à forma gráfica devido às questões por hora levantadas.

No capítulo seguinte, discutiremos a linguagem gráfica de Aloisio Magalhães e suas características frente ao projeto editorial, ampliando esta análise com estudo comparativo das obras e outros artistas. 


\section{CAPÍTULO III}

\section{ALOISIO MAGALHÃES E A LINGUAGEM GRÁFICA NO PROJETO EDITORIAL}

O capítulo que aqui se apresenta visa encaminhar nossa investigação para o campo da análise gráfica da obra de Aloisio Magalhães. É necessário dizer, que pela amplitude e pluralidade do que foi e realizou Aloisio Magalhães enquanto artista gráfico, iremos apontar em sua trajetória os pontos relevantes à sua linguagem gráfica e o projeto editorial.

Cabe ainda ressaltar que os termos, que muitas vezes acompanham Aloisio Magalhães em suas diversas atividades ligadas ao campo das artes, já são motivo para uma indagação por nossa parte. Ou seja, afinal qual seria a maior vertente expressiva de seu trabalho? O que manteve consigo ao longo de seu percurso no campo das artes plásticas, na gravura, no projeto editorial com O Gráfico Amador, ou ainda, no design? Tais questionamentos nos fazem constatar que Aloisio Magalhães primeiramente como comunicador, tinha vocação à pluralidade. 
Desde os tempos como estudante de direito, em 1947 em Recife, já despontava com forte iniciativa criativa às artes. Esteve sempre envolvido com trabalhos que o desafiaram como artista mas, principalmente, que ressaltavam a sua atividade projetiva.

Pensava, discutia. Aprendeu com os amigos que fizeram parte da sua vida e isso se deve ao grupo de intelectuais com o qual que esteve envolto em Recife, no Teatro do Estudante de Pernambuco (TEP) - a debater o próprio fazer. Neste curso do pensamento, sua linguagem no amplo sentido do que fez, era daquele que tinha primeiramente, vocação à comunicação e expressão gráfica.

Temos conhecimento das várias fases de Aloisio Magalhães frente aos campos da arte e pode nos parecer prematuro dizer, mas em todas as suas etapas de vida, duas vertentes superpostas formam a amálgama da sua força motriz. A primeira, como já apontado, é a sua familiaridade com a expressão gráfica (seja a pintura, a gravura, as técnicas mistas); a segunda, em igual proporção, é a sua capacidade projetiva, ligada ao invento, ao fazer.

A estas duas vertentes, e talvez mais ligada a última, nos aparece a extrema qualidade de observação em Aloisio. Um texto de seu amigo e pintor José Claudio, nos aponta esta localização de sua atividade linguística:

[...] em primeiro lugar é preciso resgatar o Aloisio pintor antes que se generalize ainda mais a concepção errada de que não o era, deixou de ser , ou isso era coisa de pouca importância na sua vida - quando de fato o ser pintor era nele a espinha dorsal [...] nenhuma atuação dele esteve afastada dessa sua qualidade primordial, embora a exercida em outros campos, na aparência, Ihe tenha granjeado mais fama ou poder, luxo exterior de repercussão: era o pintor, o que trabalhava com as mãos, o designer também, que movia a outra ponta do nervo que termina no cérebro (CLAUDIO in LEITE, 2003, p. 38) 
Aloisio Magalhães, como aponta o pintor José Cláudio, manteve sempre em seu cerne expressivo o pulso da linguagem plástica. Mas devemos tomar certo cuidado com tal afirmação, pois o termo não se adequa à qualidade maior a que possamos nos referir, que é a do comunicador visual.

Sim, independente de ser pintor, gráfico ou designer, sabia expressar-se pela composição das formas, do movimento das linhas e da sintaxe da linguagem visual. Era artista visual, em contínuo experimento com esta linguagem. Estava sempre em contato com os materiais e destes, na qualidade de artesão, os dava forma e significação.

Em uma primeira análise da obra de Aloisio Magalhães como um todo, devemos situá-lo no início, no campo da pintura, por onde ingressou como artista. Observando o panorama das artes na década de 1950, vemos que Aloisio não se engaja a nenhum grupo ou movimento presentes nesta época como o concreto ou neoconcreto. A sua pintura não se alinhava a nenhum destes movimentos, pelo contrário, a direção de seu trabalho compreendia o terreno de uma arte informalmente abstrata, longe de converger à arte construtiva. Percebemos pelos exemplos - vide ilustrações (66), (67) e (68) - o contexto desta afirmação, como também a característica que se acentua em seu trabalho que é a expressividade das formas e cores. 


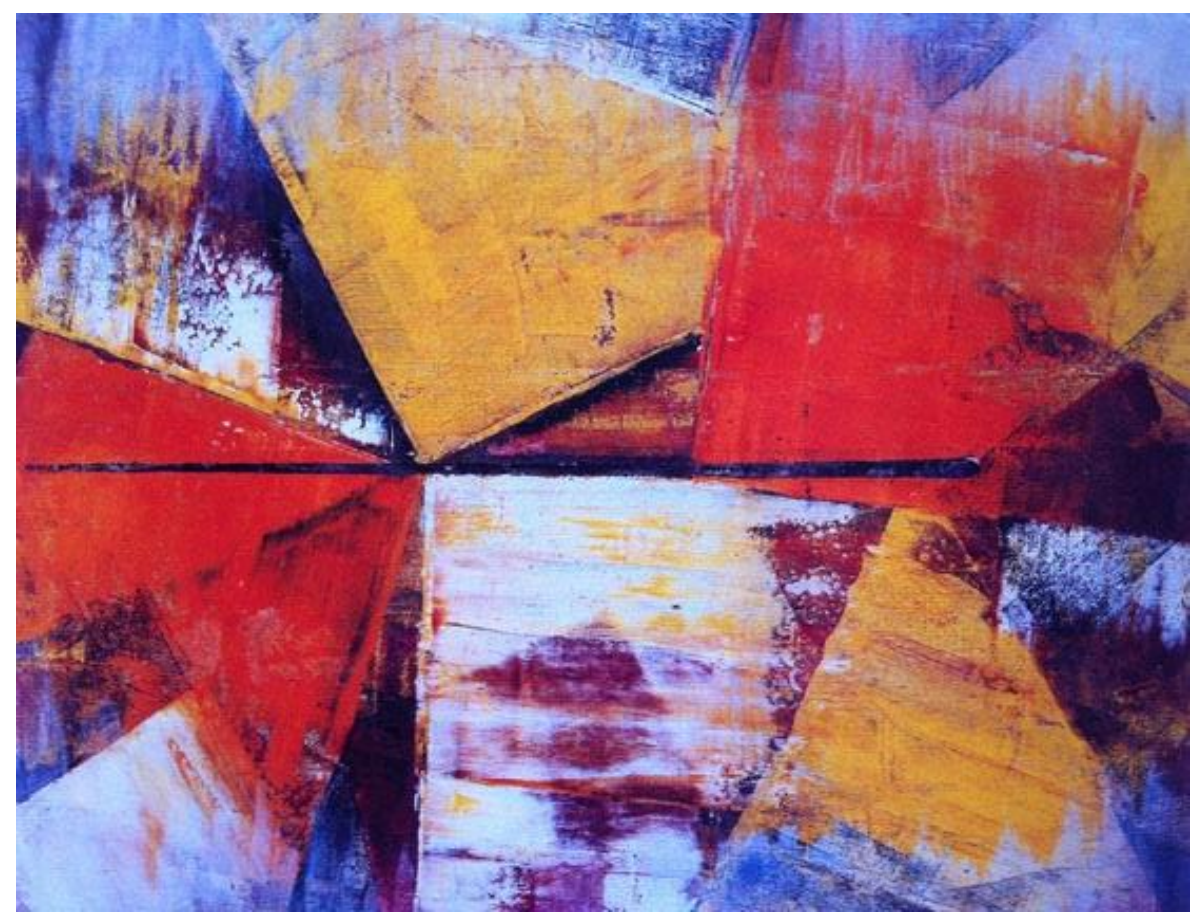

Ilustr. (66) S/ título. Tinta óleo sobre madeira.

Fonte: LEITE, 2003, p.48.

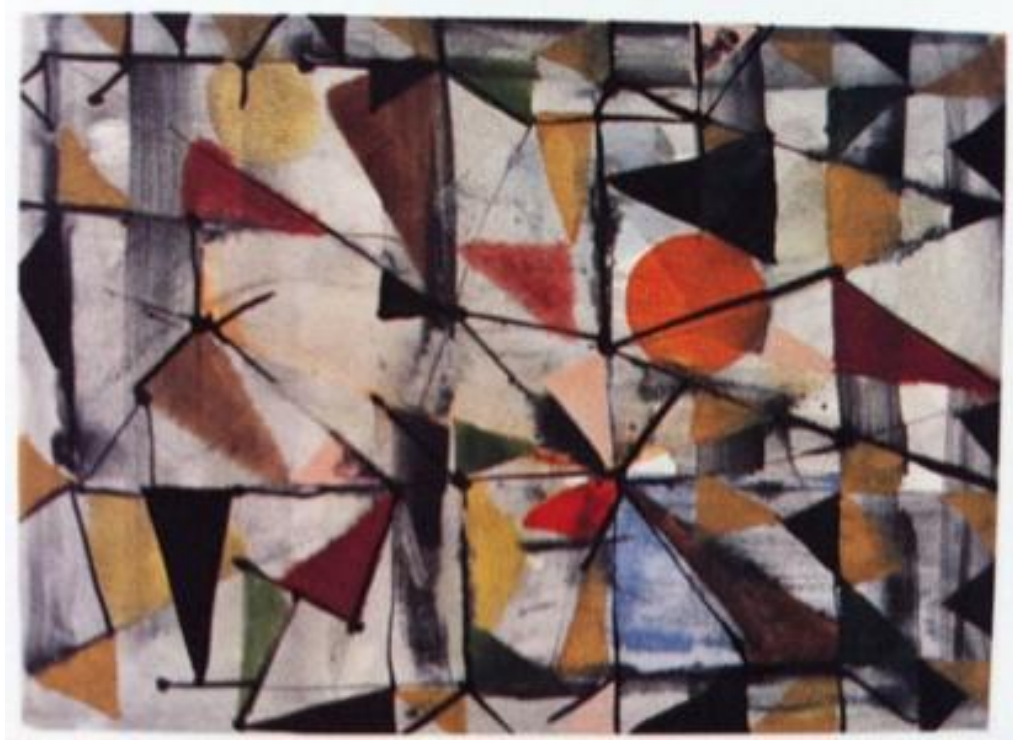

Ilustr. (67) S/ título. Aquarela sobre papel.

Fonte: LEITE, 2003, p.51. 


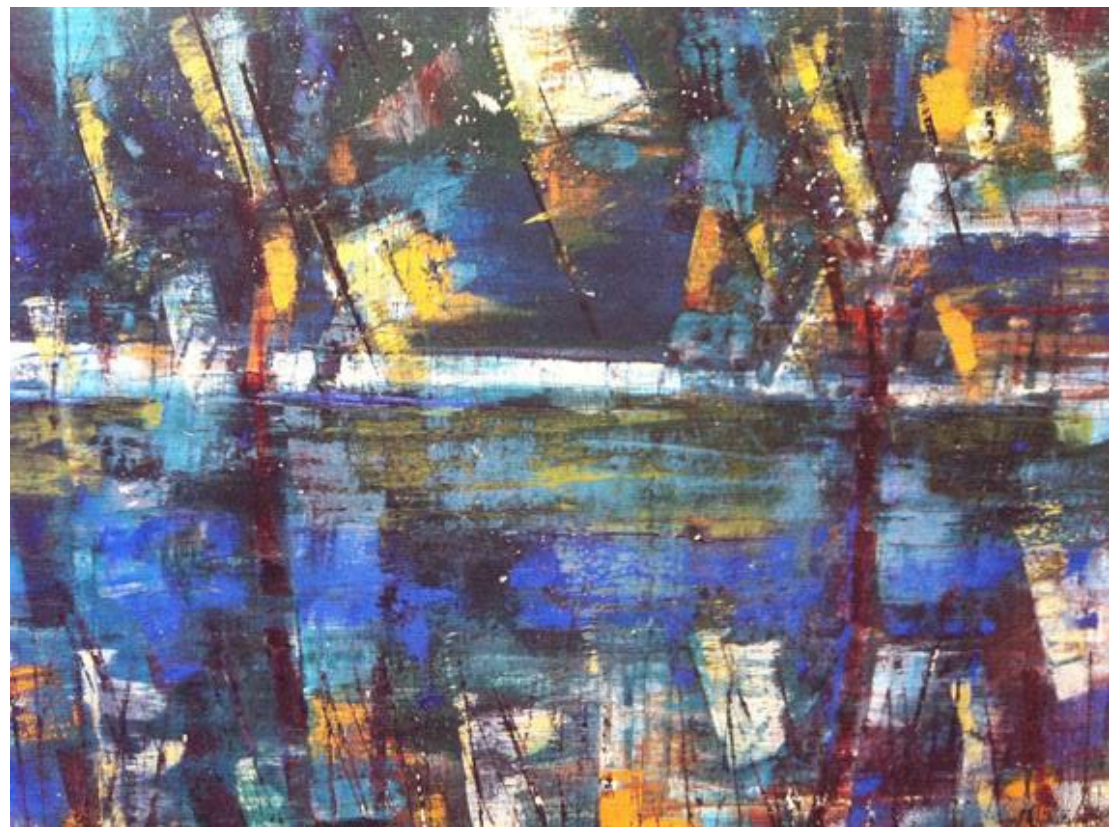

Ilustr. (68) S/ título. Tinta óleo sobre madeira.

Fonte: LEITE, 2003, p.49.

O trabalho com as formas e as cores que Aloisio emprega nas suas pinturas, deflagram o seu olhar à paisagem de sua cidade, Recife. Percebe-se nitidamente que em suas obras, Aloisio Magalhães busca nestes elementos a construção de seu discurso visual, apoiando-se na sua habilidade de abstração para criar toda uma sugestão de leitura. É de maneira sutil mas presente, que estas mesmas formas e cores nos lembram algumas paisagens do nordeste como podemos verificar nas ilustrações (69), (70) e (71). 


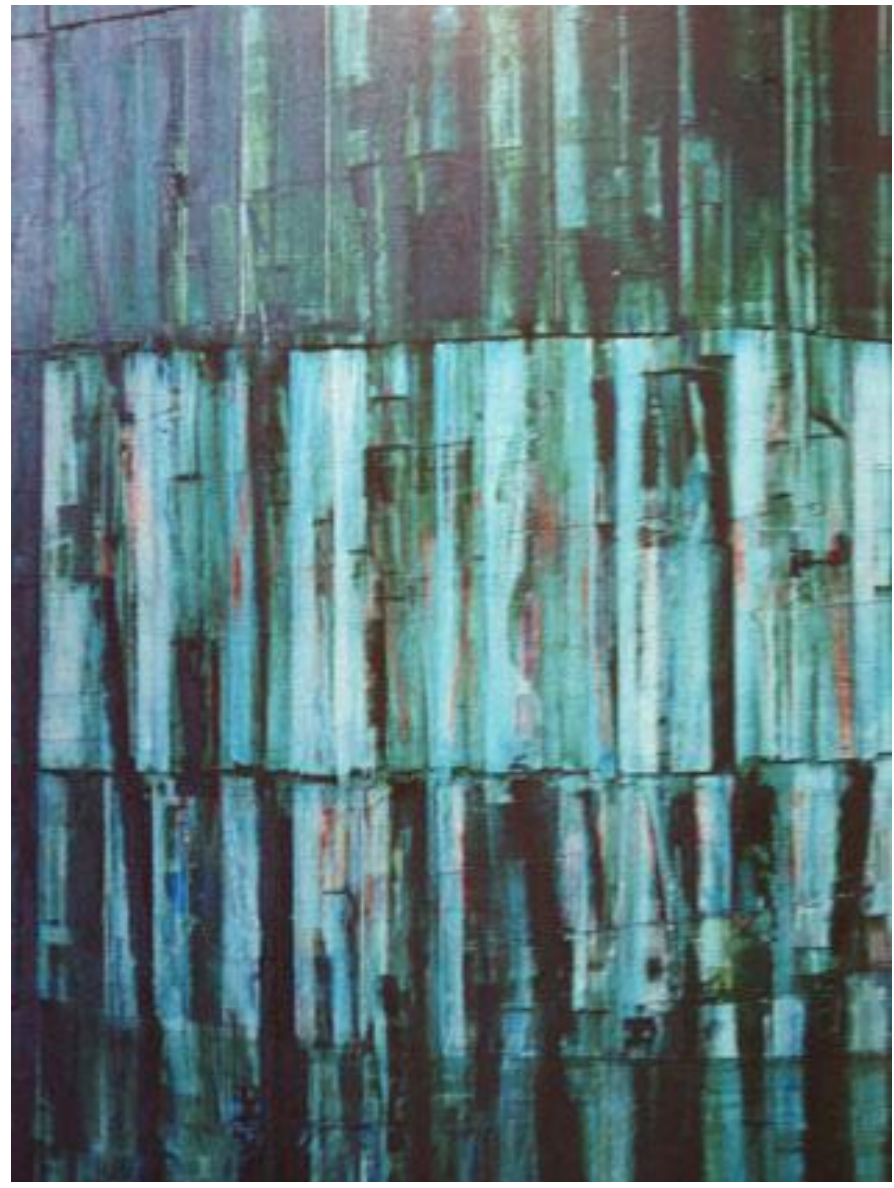

Ilustr. (69) S/ título. Tinta óleo sobre madeira.

Fonte: LEITE, 2003, p.36.

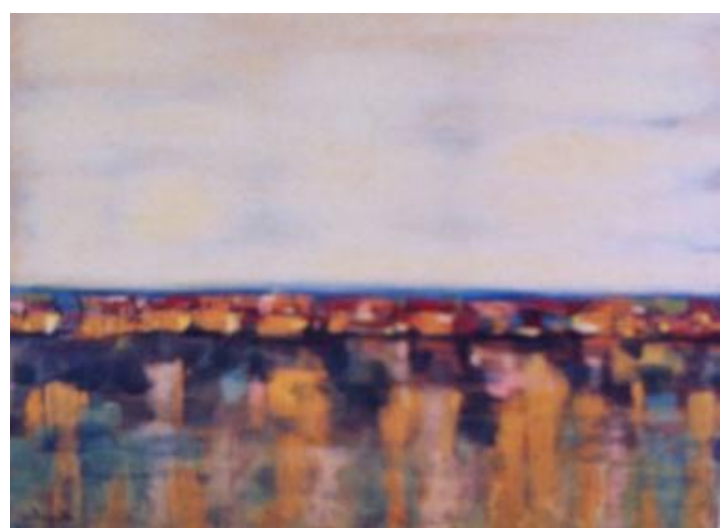

Ilustr. (70) S/ título. Tinta óleo sobre eucatex.

Fonte: LEITE, 2003, p.55.

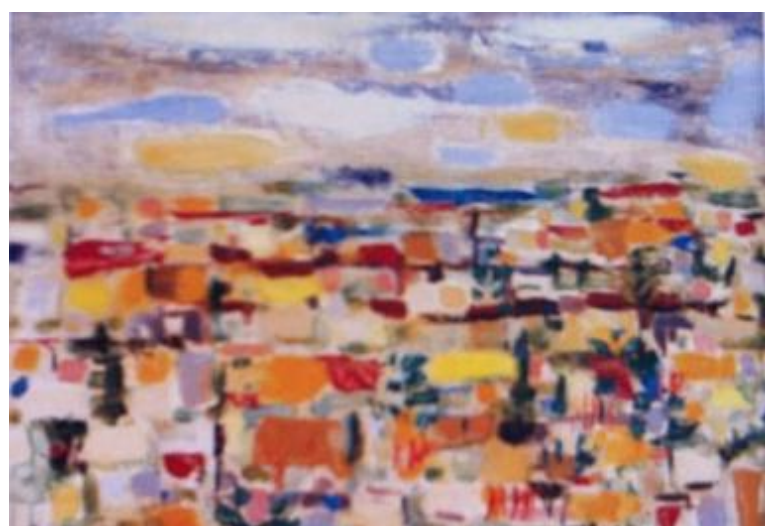

Ilustr. (71) S/ título. Tinta tipográfica sobre eucatex.

Fonte: LEITE, 2003, p.55. 
Outro dado importante, complementar à análise referente a sua construção de linguagem, deve-se a atenção do artista com a pesquisa dos materiais. As obras de pintura já denotavam suas experimentações com suportes diferenciados, desde a tinta óleo sobre madeira - ilustração (72) -, tinta tipográfica sobre papel - ilustração (73) -, e tinta tipográfica sobre tecido - ilustração (74).

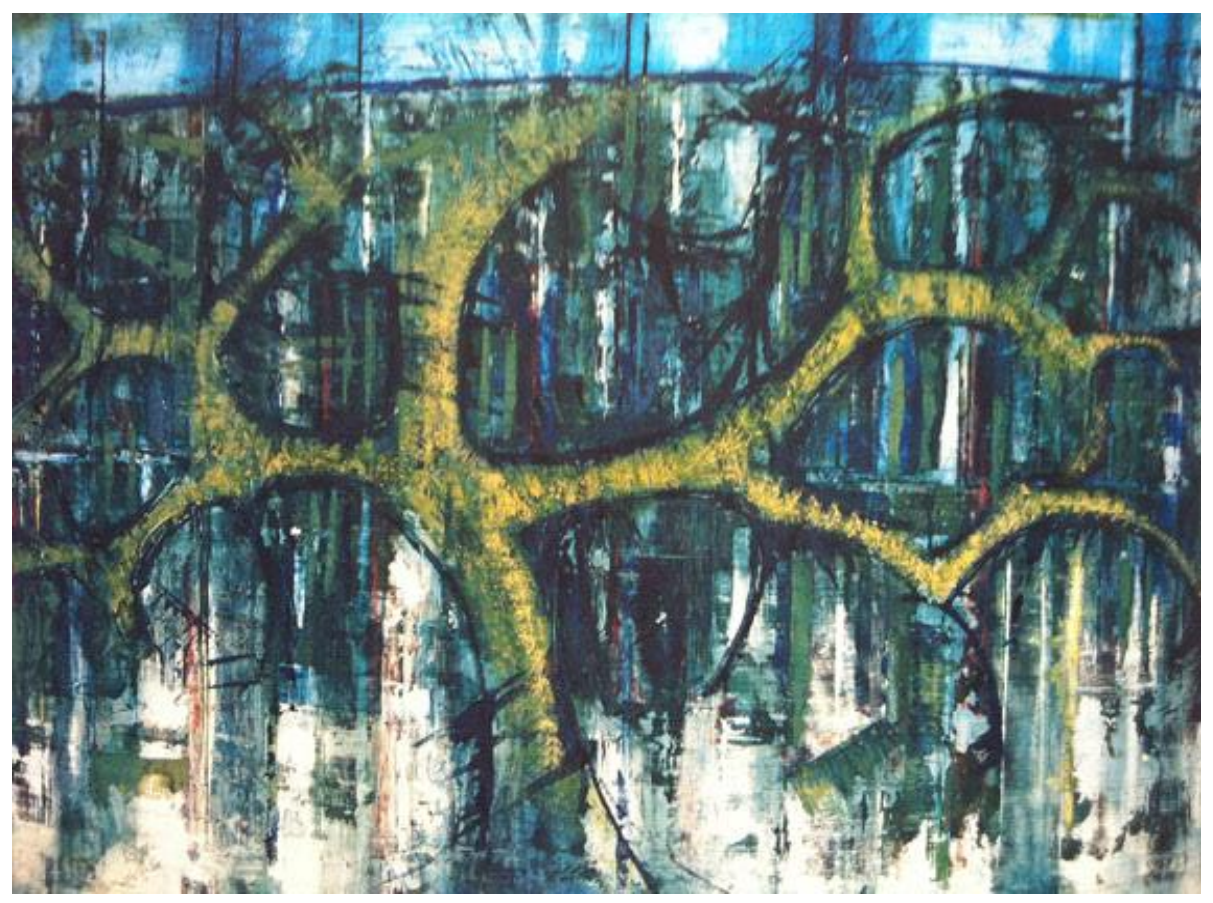

Ilustr. (72) S/ título. Tinta óleo sobre madeira.

Fonte: LEITE, 2003, p.50. 


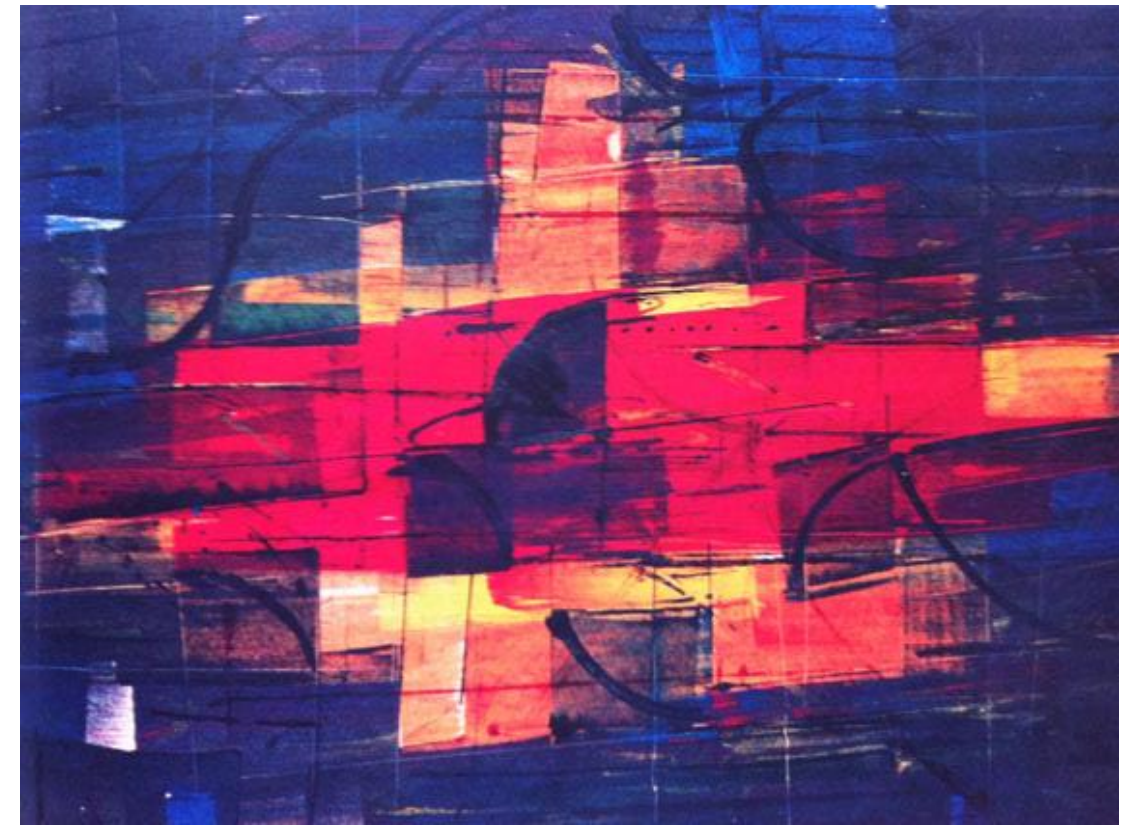

Ilustr. (73) S/ título. Tinta tipográfica sobre papel.

Fonte: LEITE, 2003, p.57.

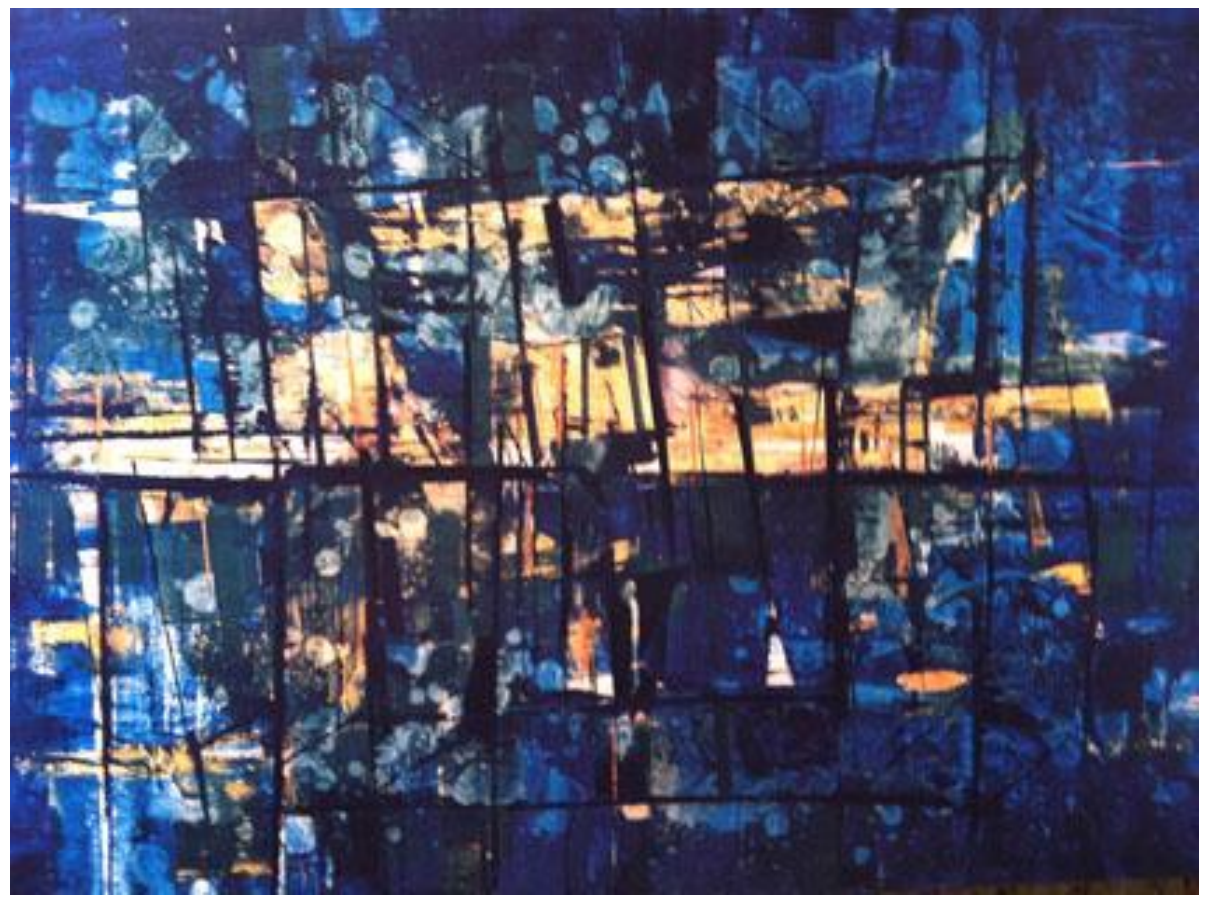

Ilustr. (74) S/ título. Tinta tipográfica sobre tecido.

Fonte: LEITE, 2003, p.51. 
Aloisio Magalhães sabia que sua linguagem acontecia no fazer, e sua erudição, não o afastava do trabalho com as mãos. Ao contrário, sempre esteve no grupo dos "mãos sujas", daqueles que moviam os projetos no pensar e na sua ação executiva. Isto Ihe conferiu uma grande riqueza de repertório e um grau de experiência, agentes motores de seu impulso inventivo. Daí a referência ao termo e ligação ao campo de sua criatividade.

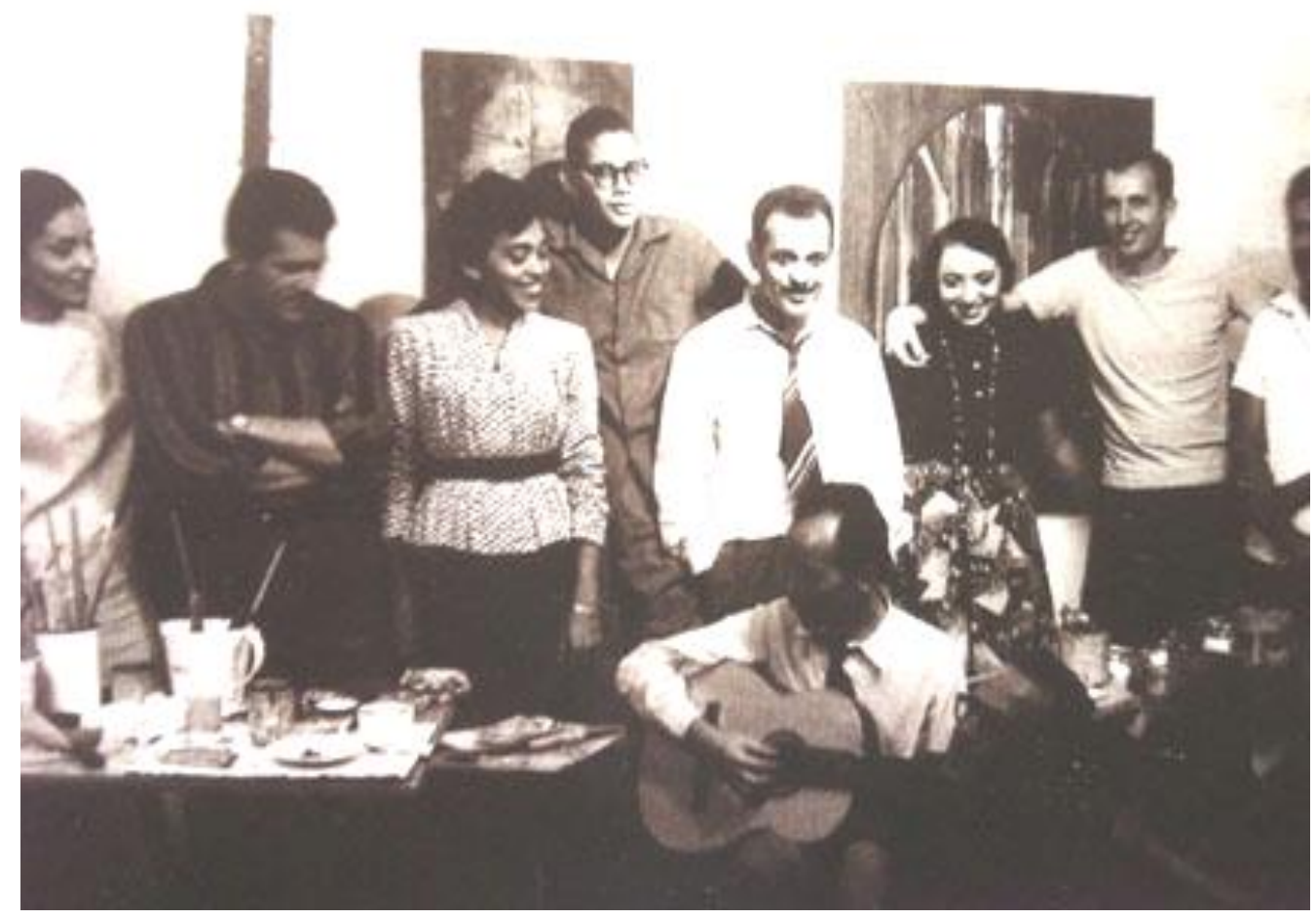

Ilustr. (75) Da esquerda para a direita, de pé: lara Lins, Jorge Wanderley, Ruth, Adão Pinheiro, Adauto, o casal Flávio Damm e Montez Magno. Sentados estão Aloisio, Aldomar Conrado e Sebastião Uchoa Leite.

Fonte: LEITE, 2003, p.45.

Em tempo, Aloisio Magalhães, em sua participação junto a'O Gráfico Amador, soube fundir estas qualidades e contribuiu aos projetos gráfico editoriais em que 
participou deixando nítida esta fluência artística bem como a de comunicador visual engajado ao projeto. Nas palavras de Antonio Houaiss,

[...] creio que no Brasil, ele, melhor que ninguém, deu à noção de "gráfico" a amplitude que através dos tempos the vem sendo atribuída. Com efeito, em "gráfico" e Aloisio conviveram 1) o que é relativo à incisão, 2) logo, à gravação, gravura, gravamento, 3) logo, à escrita, como coisa incisa, como coisa pita e, mais, como coisa fita, fingida pois dentro das linhas, dos cortes, das tintas, das cores, mais dentro ainda, estão, a luzir, as palavras, e suas ideias, e suas iluminações, 4) logo, à composição, montagem e impressão, 5) logo, ao manejo dos instrumentos e técnicas com que se criam objetos visuais (e de outros sentidos) com que se indicam, se simulam, se fingem, se simbolizam, se semiologizam, se imaginizam, se logotipam noções, instituições, valores [...] essa província gráfica da personalidade de Aloisio Magalhães não era o germe, que uma das faces de seu ser: a pintura, lato sensu (HOUAISS apud CLAUDIO in LEITE, 2003)

Encontramos na sua pintura como discorre Houaiss (1982), o sempre "gráfico" Aloisio Magalhães. E esta noção "gráfica" da qual estamos nos referindo irá acompanhá-lo em toda as etapas de sua vida profissional. De artista plástico, gráfico amador à designer. Tinha consigo o discurso da linguagem das formas, cores e texturas e colocava esta em contínuo exercício. Deste modo, a cada etapa de sua vida no campo das artes, do projeto editorial ou mais tarde enquanto designer, vivenciou os diferentes modos de engajamento do sentido "gráfico" de sua matriz criativa no papel de comunicador visual.

Devemos enaltecer uma qualidade em Aloisio Magalhães como artista, que é a observação. Seus trabalhos trazem todo um aspecto da cultura brasileira que partem de sua introjeção à mesma. Isto é, Aloisio transparece em sua linguagem, o 
laço extreito que possuia com sua cultura local. Uma fluência linguística que se caracterizava primeiramente por ser Pernambucano. Isto é, como nos aponta João de Souza Leite:

[...] desse Recife, onde a elite estabelece vínculos especiais com as classes populares, em processo muito característico da região, saiu para conhecer o mundo. O cosmopolitismo das grandes capitais se associa à vivência da cultura nordestina, pois mesmo que as diferenças fossem radicais entre elite e expressão popular, é o Nordeste brasileiro, sobretudo Pernambuco, que essa mesma elite se envolve nas manifestações mais radicais da experiência popular (LEITE, 2003, p. 25)

Aloisio Magalhães construiu todo um repertório artístico e alcançou fluência com este, a partir da gênese cultural pela qual tinha como berço. Este contexto apresenta-se nas monotipias em papel feitas nos anos de 1950, como também, em algumas séries de aquarelas como mostram as ilustrações (76) e (77).

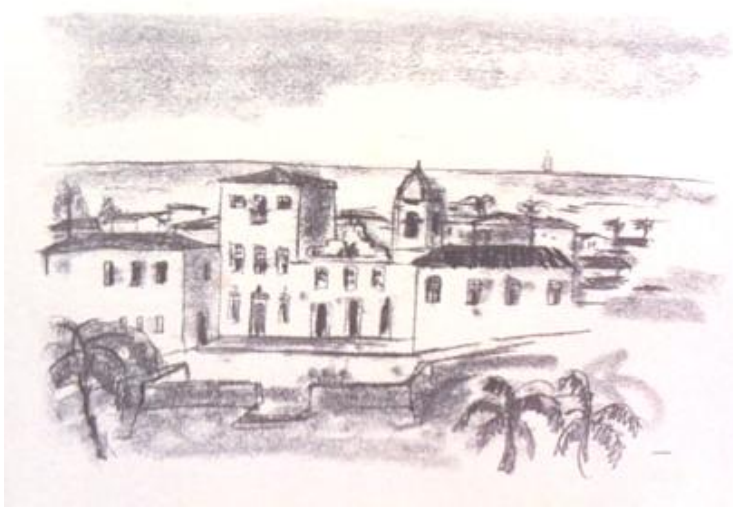

Ilustr. (76) S/título. Monotipia sobre papel.

Fonte: LEITE, 2003, p.46.

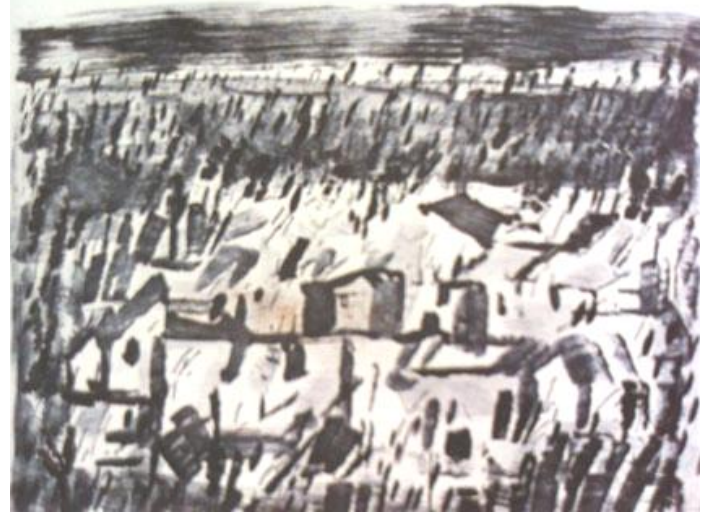

Ilustr. (77) S/título. Monotipia sobre papel, 1957. Fonte: LEITE, 2003, p.46. 
Aliado a isto, pelas suas viagens ao exterior, pode estar ao mesmo tempo com os pés fincados à cultura regional e ao mundo. Nas palavras do autor, "[...] é desse modo que se constitui a matéria primeira de Aloisio - sofisticação intelectual mesclada à manifestação popular." (LEITE, 2003, p. 25).

O caminho de sua trajetória artística, nesse ponto de vista, é a tradução que Aloisio Magalhães como pessoa, revela naturalmente na qualidade de flâneur. Este observador que foi, caminhou introjetado em sua cultura, fazendo dela a própria experiência de seus sentidos e a vazão de seu senso artístico. Assim como o poeta Charles Baudelaire que entendia o papel do flâneur como elemento fundamental ao entendimento do processo de modernidade, do cosmopolitismo pelo fluxo da cidade, Aloisio Magalhães, o fez em outra instância de tempo, ao se portar regional e universal.

Talvez seja esta a linha condutora das suas razões para com a cultura brasileira. Todos nós sabemos de sua preocupação em defesa destes ideiais, e da verdade que o seu discurso continha quanto aos valores enaltecidos e intrínsecos a ela. Na qualidade plural de artista, exercitou esta observação, numa certeza quase que absoluta do que propunha e fazia.

Outro ponto importante e que vai somar-se às suas características artísticas, é que, deste sentido de observação, também tomou partido para ter contato extreito com os materiais e assim explorá-los. Aloisio Magalhães, desde seu início no campo artístico, travou este relacionamento com os elementos de sua linguagem. Aprendeu construindo, exercitou a observação mas acima de tudo, a prática. São suas as palavras que contam este percurso:

[...] contato com os materiais puros, observá-los detidamente, analisar a sua resistência, o seu peso, as suas possibilidades de 
aplicação, sentir-se por que a pedra é pedra e dura, e como usá-la. Prescindir dos materiais pobres e preferir os nobres. Usá-los como artesão e como criador. Depois, e mais fundamentalmente ainda, saber usar o olho. O olho seletivo, o olho treinado. O olho que sabe ver e sabe relacionar e selecionar. A observação profunda da natureza, constante, diária, "obsessional". O olho, se quiserem, viciado, que relaciona e constata. Depois, uma profunda integração na vida (MAGALHÃES in LEITE, 2003, p. 59, grifo do autor)

Em relação às técnicas que praticava, foi de grande importância sua vivência em Paris em 1951, com a bolsa concedida do governo francês para estudar museologia no Louvre. Foi nesta época que frequentou o Atelier 17, de Stanley William Hayter. Este atelier foi um importante espaço para a experimentação das artes gráficas e exerceu importante papel "[...] na reabilitação das técnicas de gravura no século XX [...] entre seus frequentadores, no primeiro período parisiense, estavam Joan Miró, Hans Arp e Yves Tanguy." (LEITE, 2003, p. 35).

Este repertório do campo da gravura, Ihe deu com certeza, ao lado do que conhecia nos campos da pintura, o mote principal para a sua expressão gráfica. É bom que se diga, que a amplitude de sua linguagem era proporcional à constante pesquisa com as técnicas e suas variações. Se observarmos com atenção os desdobramentos da técnica da pintura aliado às técnicas da gravura - e aqui pontuamos a xilogravura, o clichê com barbante, a gravura em linóleo, a litogravura e o pochoir - veremos que Aloisio Magalhães na fase d'O Gráfico Amador, possuia um repertório muito rico para explorar a fluência do seu desenho.

A linha alcança novas possibilidades de movimento e gestualidade quando encontra a matriz com barbante. As cores, como em presente estado de discurso pictórico, formam par ao movimento e sugerem nova proposição aos temas. Nada fixo, mas muito equilibrado e disposto ao espaço, que assim é amplo, limpo e sutíl. 
As texturas aparecem carregando consigo quase que um mundo à parte. Fluem à imaginação e indulção temáticas e, sugestionadas pelo artista, parecem que marcam sempre a sua noção de tempo/ espaço de seu eixo cultural. É regional mas universal.

As citações que por hora foram feitas em relação ao seu trabalho gráfico, e com a técnica do clichê com barbante se exemplificam na ilustração (78). Fazem parte do livro Aniki Bobó, cuja autoria é de Aloisio Magalhães e João Cabral de Melo Neto. Segundo Guilherme Cunha Lima (1994), os desenhos foram feitos antes do texto e por esta razão, no colofão do livro encontra-se descrito: “ ilustrado com texto de João Cabral". O projeto de design é de autoria de Aloisio Magalhães.

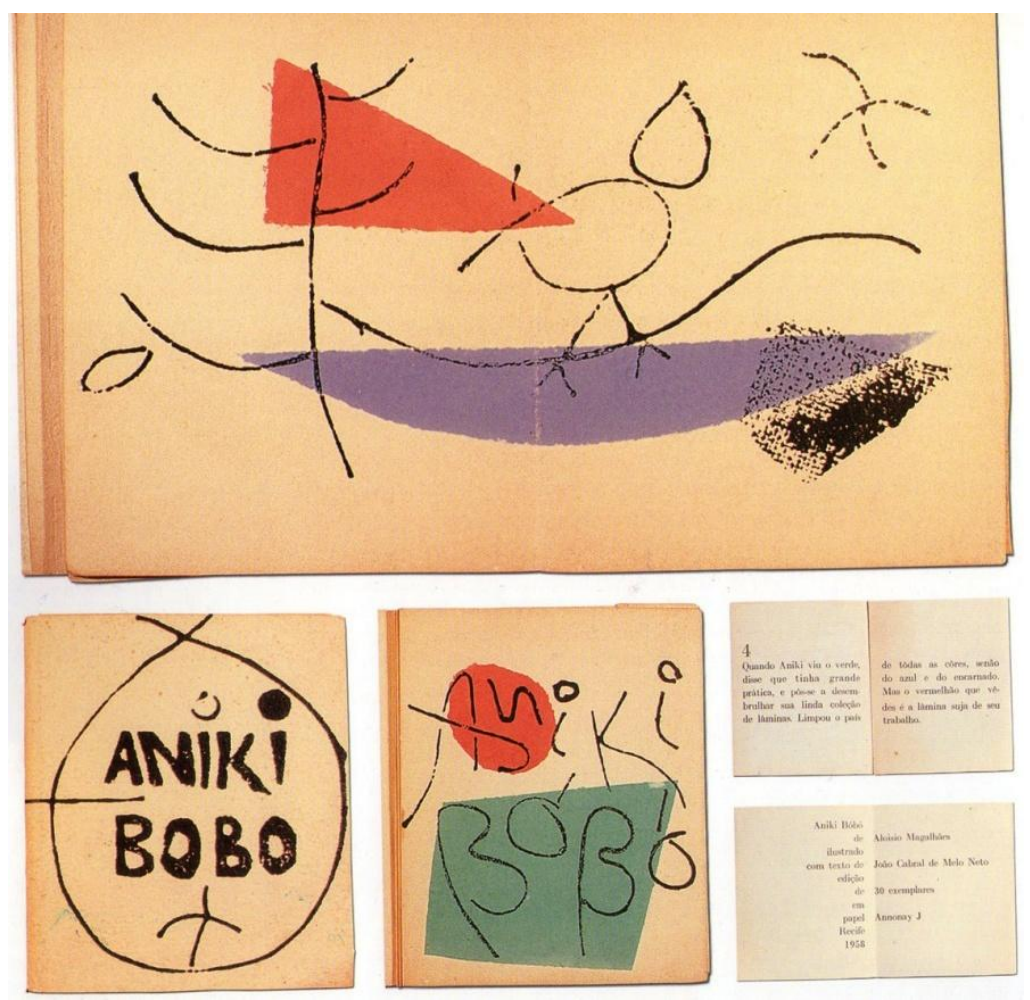

Ilustr. (78) Aniki Bobó. O Gráfico Amador, Recife, 1958.

Fonte: LEITE, 2003, p.46. 
Quanto à composição tipográfica, em Aniki Bobó, Aloisio Magalhães utilizou a fonte Bodoni para os textos. Adequa um corpo elevado para a proporção do formato da página e pouca quantidade de texto, ao mesmo tempo em que abre o entrelinhamento para o devido respiro da mancha. Por ser uma fonte de alto contraste entre traços grossos e finos, mesmo com um corpo de valor alto, as palavras tornam-se leves, destacadas e elegantes.

Há uma característica comum presente nos livros d'O Gráfico Amador quanto ao trabalho tipográfico que é o equilíbrio. Existe uma dinâmica na fluência entre imagem e texto das páginas dos livros, que regem a condução da leitura. Isto é, a leitura se dá pelo conjunto (texto - imagem) que se interliga, não havendo predominância de um destes quanto a uma hierarquia de valores. A leitura é sugestionada por este conjunto, que bem resolvido em sua disposição gráfica, dá fluência e ritmo cadenciando a observação. Um convite para a sucessão dos detalhes. A ilustração não se distancia do texto e toma um sentido diferenciado nas obras d'O Gráfico Amador. Ou seja, ela nasce como texto e é literalmente seu conteúdo em forma plástica. Desse modo, o sentido do conteúdo é o perfil integrado, quase homogêneo destes dois elementos: texto e imagem.

Esse modo de organização gráfica exemplifica-se na ilustração (79). A obra em destaque é Memórias do Boi Serapião, de Carlos Pena Filho, com design de Gastão de Holanda, José Laurenio de Melo e Orlando Ferreira - O Gráfico Amador, 1955. As ilustrações e a sobrecapa foram feitas por Aloisio Magalhães com desenhos sobre a chapa de impressão que, neste caso, não se deu em tipografia e sim em offset. 


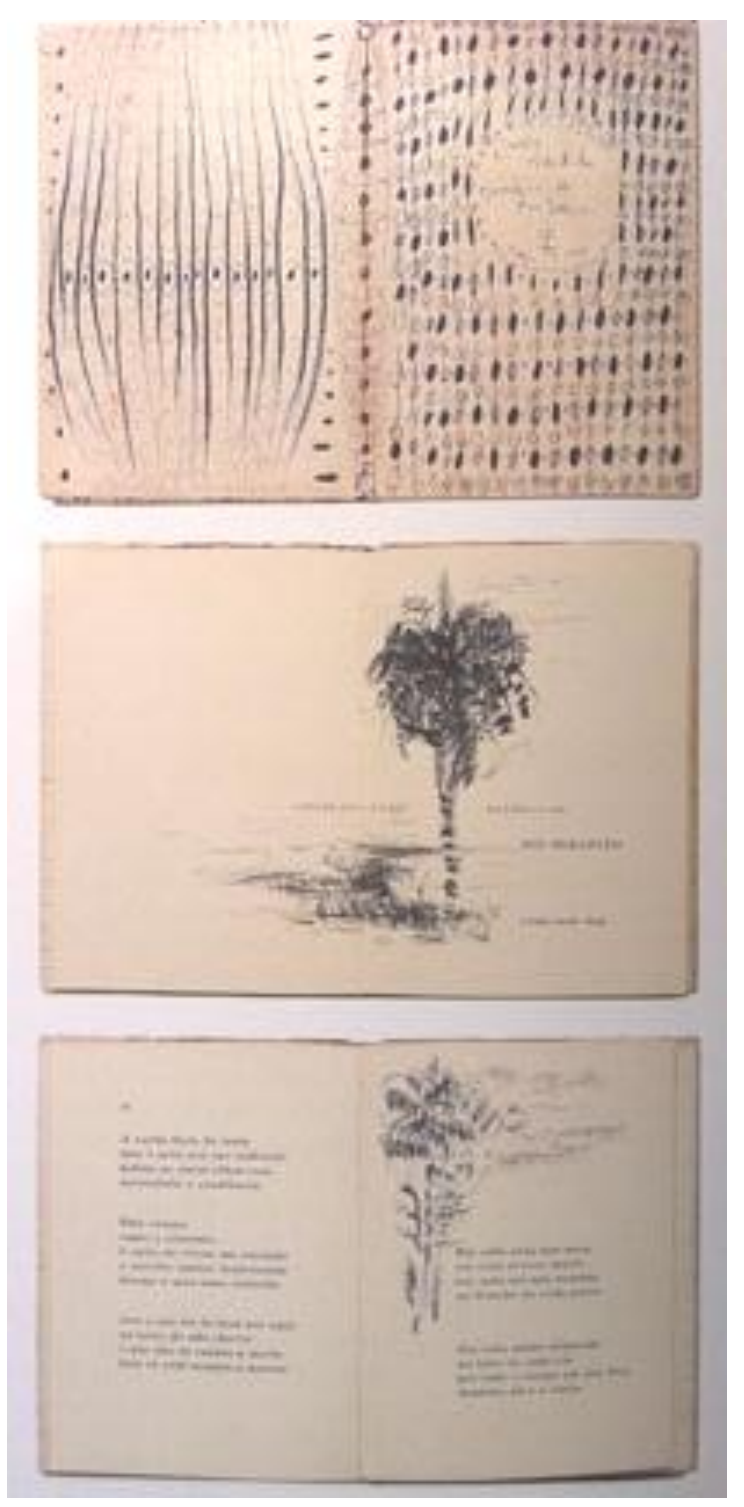

llustr. (79) Memórias do Boi Serapião.

O Gráfico Amador, Recife, 1955.

Fonte: LEITE, 2003, p.90.

Outro bom exemplo do trabalho gráfico de Aloisio Magalhães junto a'O Gráfico Amador é o livro Pregão Turístico do Recife, de João Cabral de Melo Neto. Neste caso, a dinâmica exposta entre texto e imagem é a confluência total destes elementos, pois, aqui, tanto os desenhos como o texto em si foram feitos diretamente sobre as chapas de impressão. Tornam-se a partir de então, um desenho único, como podemos ver na ilustração (80). 

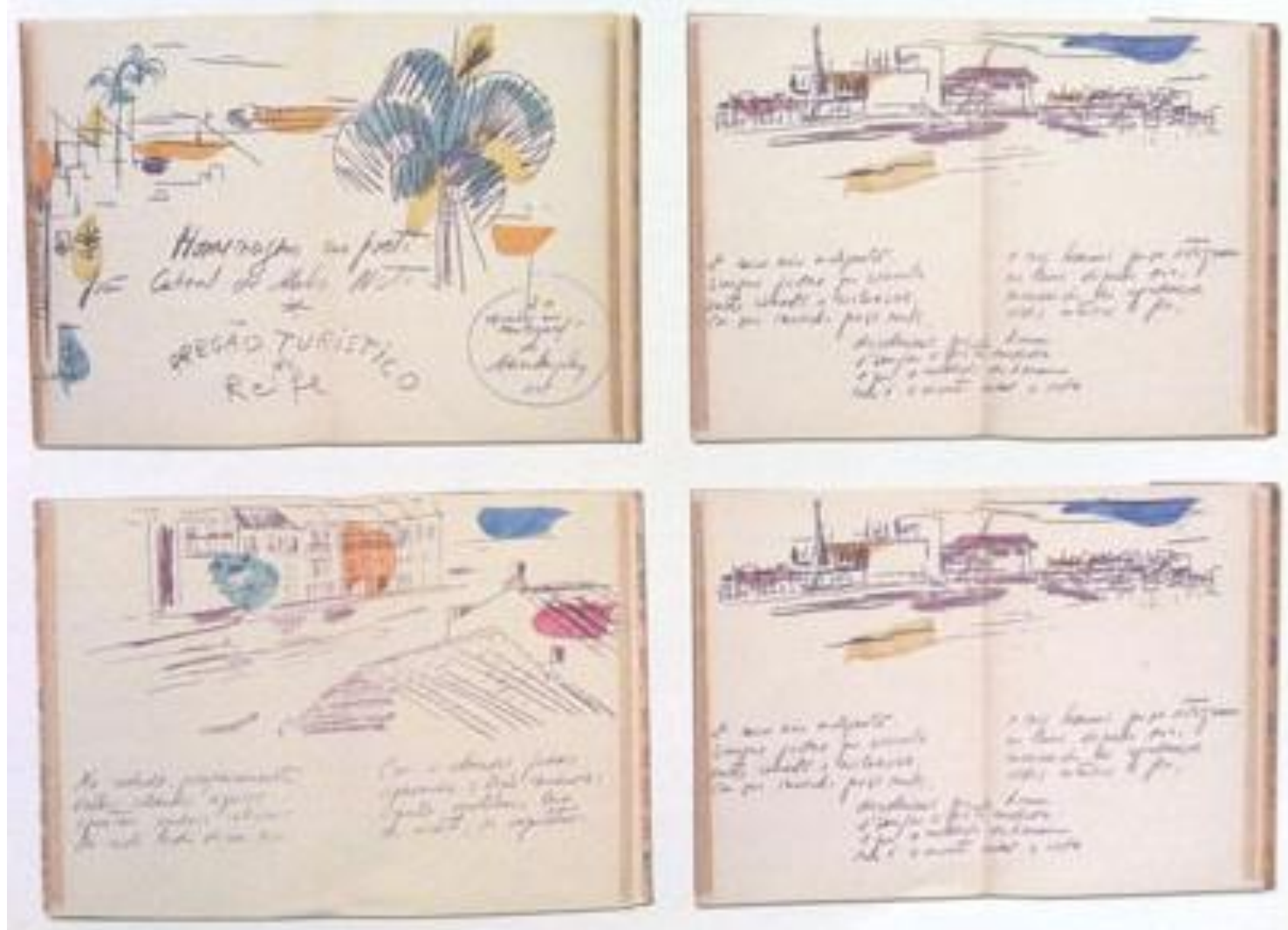

Ilustr. (80) Pregão Turístico do Recife

O Gráfico Amador, Recife, 1955.

Fonte: LEITE, 2003, p.87.

Ainda que não considerado enquanto obra d'O Gráfico Amador, o livro Improvisação Gráfica, cujos textos são de vários autores, foi realizado na oficina do grupo em 1958. O livro é uma síntese do que estamos abordando enquanto linguagem gráfica e o uso de diferentes técnicas. Nele, Aloisio Magalhães, explora a diversificação de sua linguagem gráfica, realizando dez experimentos tipográficos (com tipos móveis) em folhas soltas e papéis diferenciados. Cada impressão é a proposta de um ensaio gráfico a partir da interpretação dos textos, que por assim desenvolver-se, concerne particularidades a cada uma das composições. 
Observamos nessa obra a alternância na composição dos textos que não seguem uma unidade formal mas que conseguem apresentar um sentido de conjunto. O projeto se utiliza de diferentes corpos de tipos, bem como estilos das famílias tipográficas, o que intensifica ainda mais a especulação da linguagem gráfica e a relação da diâmica entre texto e imagem.

O trabalho também possui uma rica variação de texturas, e isto deve-se ao fato de Aloisio Magalhães ter utilizado na impressão, matrizes de madeira, fios de latão, linóleo, pochoir, além dos tipos móveis.

Observamos também que a cor recebe a função de estruturar o trabalho feito com os tipos e, dentro desta premissa, ela surge em tons leves, aproximando-se do sépia em algumas impressões. Excessão à regra, são as páginas com os tons quentes.

Esta obra-ensaio, é uma qualificação do processo da linguagem gráfica de Aloisio Magalhães e o projeto de um livro. Ela sinaliza a experimentação, a compreensão do artista diante de seus recursos e a resposta pelo fazer. $\mathrm{Na}$ ilustração (81) podemos verificar os detalhes destas composições. 

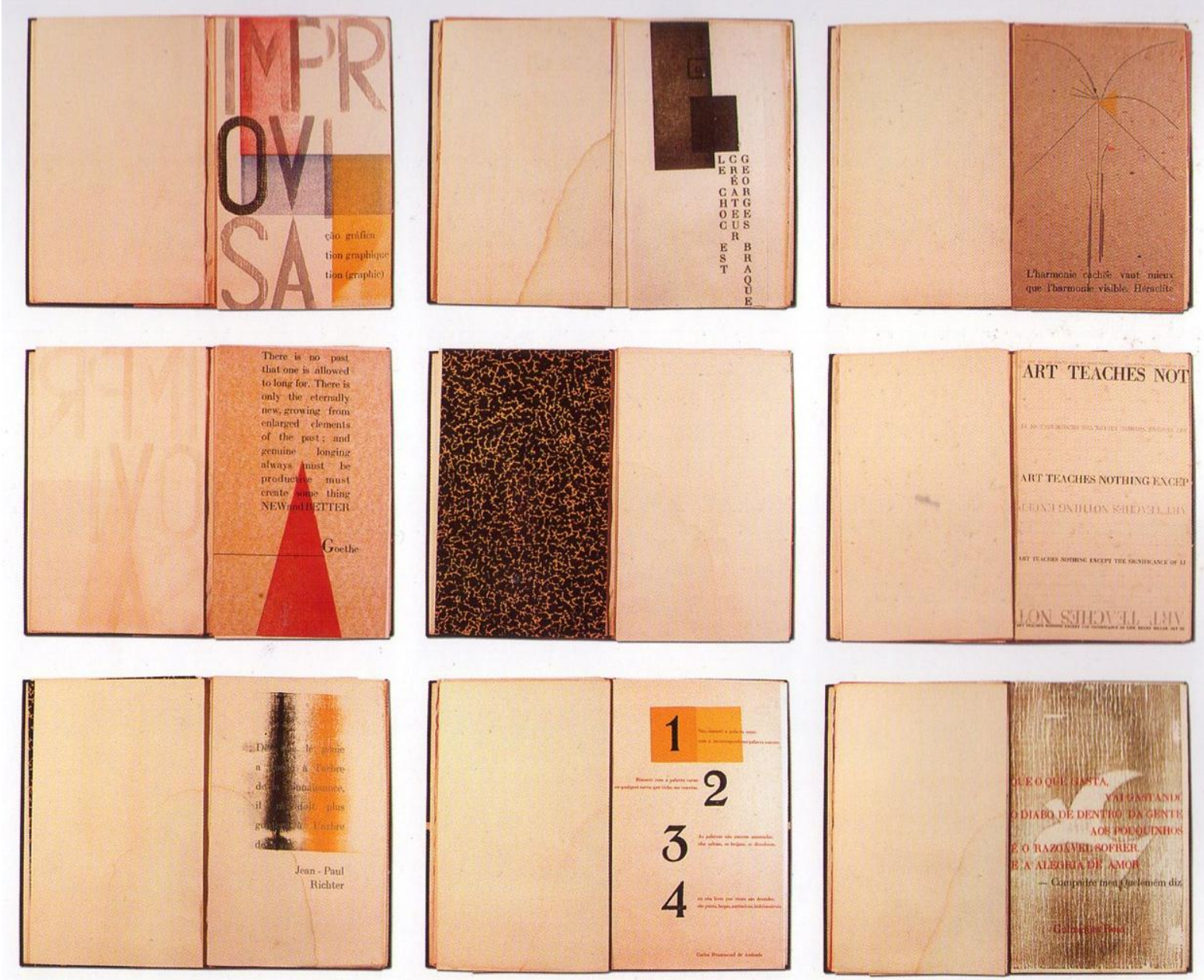

Ilustr. (81) Improvisação Gráfica O Gráfico Amador, Recife, 1958. Fonte: LEITE, 2003, p.107.

Percebe-se n'O Gráfico Amador que o trabalho de Aloisio Magalhães, a esta altura, já contava com uma profusão de técnicas e servia-se de uma qualidade tácita do artista em relação a linguagem gráfica, a conscisão. Podemos observar, desde o símbolo gráfico feito por ele para O Gráfico Amador - ilustração (82) -, que a sua linguagem é caracterizada tanto pelo grau de refinamento quanto pela retenção de seu conteúdo semântico. 


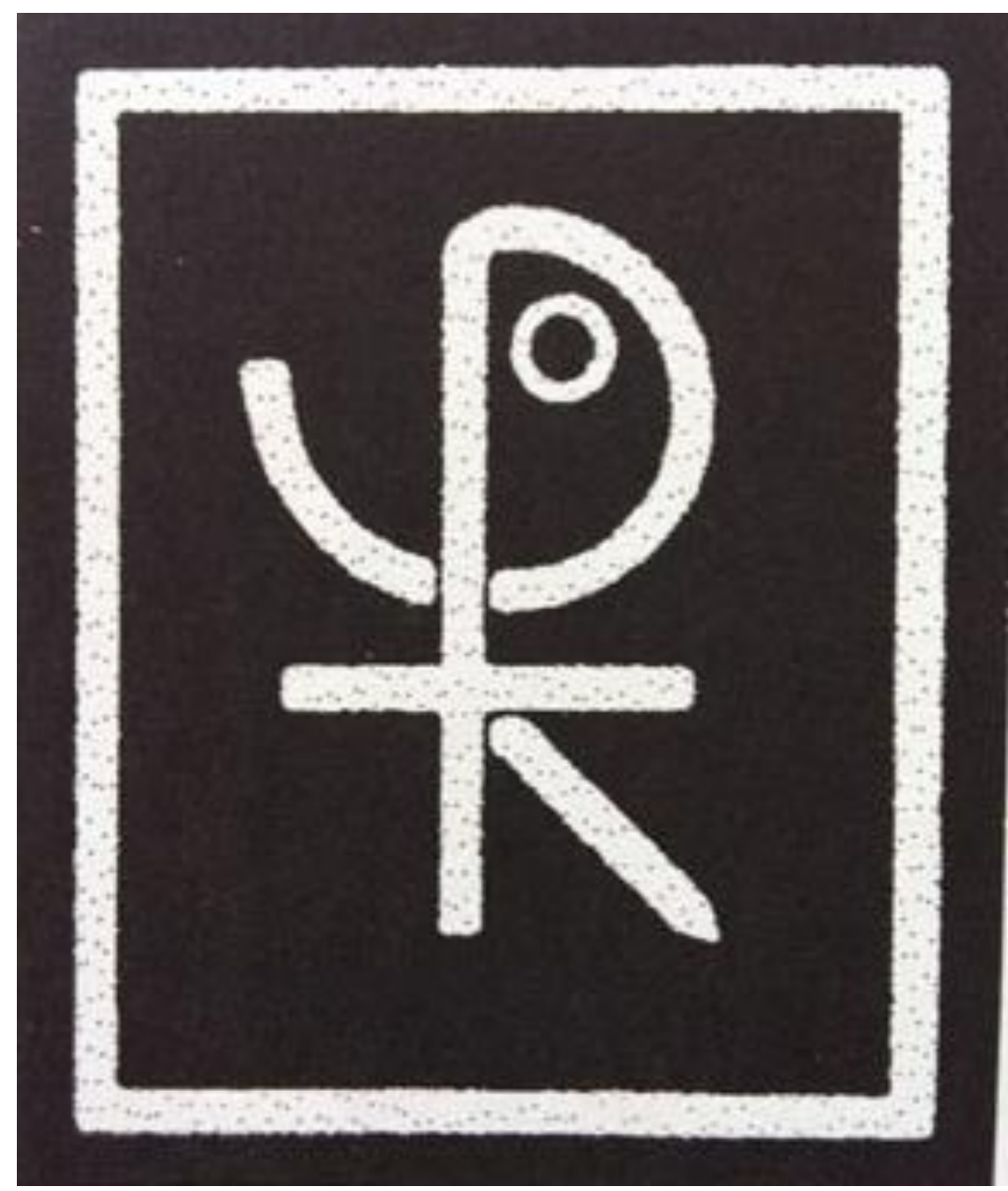

llustr. (82) Símbolo d'O Gráfico Amador Fonte: LIMA, 1997, p.108.

Ele mantém seu curso dentro da expressividade, mas seu trabalho, ainda longe dos símbolos gráficos do design, desponta com poder de síntese. A imagem é concentrada de valores com poucos elementos. Daí a riqueza de seu apurado discurso, que deste modo, transcende a simples ilustração complementar ao texto.

Portanto, n'O Gráfico Amador, Aloisio Magalhães funde sua capacidade expressiva, projetiva e inventiva. Ele evidencia o experimento com os materiais, seus limites e uso das técnicas. Era "mão suja" e pelo contato direto com o fazer construido dentro do exercício de atelier - delineia sua linguagem gráfica a partir deste curso. Nos cabe ainda dizer, se prescindirmos de uma análise comparativa da 
linguagem gráfica de Aloisio Magalhães frente à outros artistas - que também trabalharam nestes moldes de atelier tipográfico -, que a ênfase se deu na sua fluência com toda a dinâmica de sua expressividade plástica. Isto é, no curso de seu desenvolvimento enquanto artista, encontra n'Gráfico Amador, um espaço que iria invocar todo este sentido de criação e experimentação gráfica.

Não podemos também deixar de dizer que se tratava de um projeto coletivo, com fins editoriais, ligado à poesia. O grupo tinha em mente, desde o primeiro livro Conversações Noturas, de José Laurenio de Melo - que a atitude projetiva deveria estar aliada à experimentação e que desta experiência embrionária (e se quisermos considerá-la como protótipo) poderiam encaminhar à futuras edições comercializadas em maior escala (LIMA, 2001).

Neste pensar, o trabalho coletivo era entendido pelo conjunto de todas as práticas que envolviam um projeto editorial nestes moldes, isto é, desde o texto, sua formatação, diagramação, composição, impressão, acabamento até a publicação.

Assim, o trabalho gráfico de Aloisio Magalhães, na época, era voltado à pratica desta experiencia que equilibrava o trabalho plástico junto à tipografia enfático no imprimir pela matriz, pelas técnicas mistas de gravura ${ }^{30}$.

\footnotetext{
${ }^{30}$ As técnicas de gravura utilizadas por Aloisio Magalhães junto ao Gráfico Amador, foram inicialmente descritas na parte introdutória desta tese. Complementa-se a informação com a seguinte nota: A "impressão com barbante" era realizada colando-se o barbante à uma base (suporte) de modo a criar um clichê (matriz) para ser acoplado na impressora tipográfica (minerva) e assim imprimir. Os clichês de metal utilizados amplamente pelas tipografias a partir do século XIX também estiveram presentes no trabalho artístico d'O Gráfico Amador. A gravura em linóleo é uma técnica similar à xilogravura (madeira), que tem como material o linóleo, de superfície mais lisa e de fácil entalhe. Pela sua propriedade mais flexível, também possibilita o recorte das figuras, como foi o caso em alguns projetos d'O Gráfico Amador (inclusive com letras capitulares). A litogravura é a técnica de gravura de superfície onde o desenho é feito em pedra calcária (utiliza-se lápis gorduroso). O processo de impressão tem como princípio a repulsão da água aos corpos graxosos. Os traçados são feitos com carvão litográfico (gorduroso). Com a pedra molhada, a tinta de impressão só adere às partes que contém imagem (gordura) e permite, sob pressão, a reprodução dessa imagem sobre papel. A descoberta da técnica é creditada a Alois Snefelder por volta de 1796. Outra técnica utilizada por Aloisio Magalhães é o pochoir, cuja origem é desconhecida mas que se afina à técnica de reprodução da imagem pelo stencil (matriz vazada). Pode variar de material e foi muito utilizada na ilustração de livros no Brasil. Seu recorte normalmente se dá com tesoura ou estilete.
} 
No que tange à linguagem tipográfica, portanto, não vemos no trabalho de Aloisio Magalhães uma linguagem que parta unicamente deste instrumento ou que dê ênfase a explorá-lo enquanto elemento principal de seu discurso, apesar de todo cuidado e requinte com o qual ele se propunha a editar e ilustrar os livros n'O Gráfico Amador. Seu trabalho com a tipografia era muito cuidadoso, bem elaborado, sutil, e assim conjugava-se com o processo como um todo.

Ao citarmos esse entendimento acerca de Aloisio Magalhães, sua linguagem gráfica e o trabalho com tipografia, nos vem imediatamente a referência de outros artistas, poetas e tipógrafos que trabalharam em semelhante contexto no século XX.

Não nos cabe aqui explorar esse tipo de investigação, mas ao menos lembrálos nesta reflexão, como é o caso da poesia de F.T. Marinetti na estética futurista, o "desenho com tipos" na poesia cubista de G. Apollinaire ou ainda no exemplo russo pelas mãos de El Lissitzki, Pevsner e Rodchenko. Esses últimos, certamente, grandes contribuidores para a história da arte moderna, junto a outro nome de vanguarda, talvez o artista mais engajado à tipografia nesse sentido, o russo llia Zdanevich. Segundo Norberto Gaudêncio Junior (2004, p. 64):

[...] como tipógrafo, sua escolha e arranjo dos tipos era precisa: de sua localização às variantes de corpo e estilo de letra, tudo era pensado e estruturado para enfatizar o caráter visual de um produto manufaturado. Zdanevich se aproxima de Marinetti, porém algumas diferenças são nítidas. Podemos afirmar que Marinetti foi um experimentador com pouco conhecimento de tipografia. Vislumbrou com excessos a diversidade da caixa tipográfica, empilhando tipos e quebrando palavras. Zdanevich, por sua vez, diagrama seus poemas como um designer que conhece profundamente a técnica tipográfica, extraindo dela todo seu potencial (GAUDÊNCIO JUNIOR, 2004, p. 64 , grifo do autor) 
Não poderíamos deixar de citar, desse modo, o trabalho de tipografia que em muito converge com essa linhagem de artistas que exploram o sentido plástico da composição tipográfica, o do holandês H.N. Werkman (1882 - 1945). Seu trabalho com tipografia é uma das mais belas sínteses da realização plástica com a composição dos tipos e a experimentação gráfica. Editou na década de 1920 uma revista entitulada Next Call, uma verdadeira obra de poesia tipográfica. Nas ilustrações (83), (84), (85) e (86) podemos conferir uma pequena mostra de sua obra:

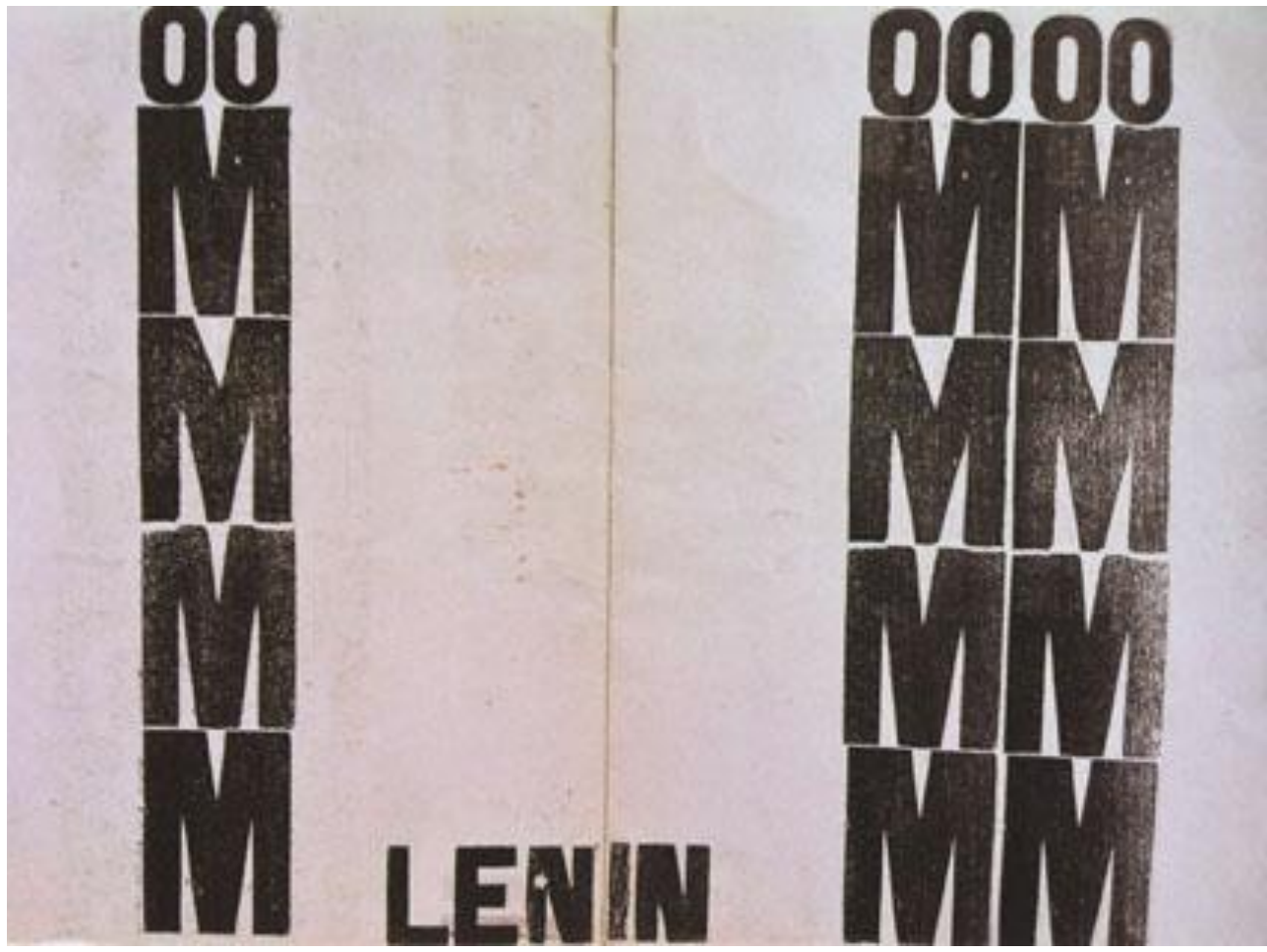

llustr. (83) The Next Call 4

Fonte: PURVIS, 2004, p. 36. 


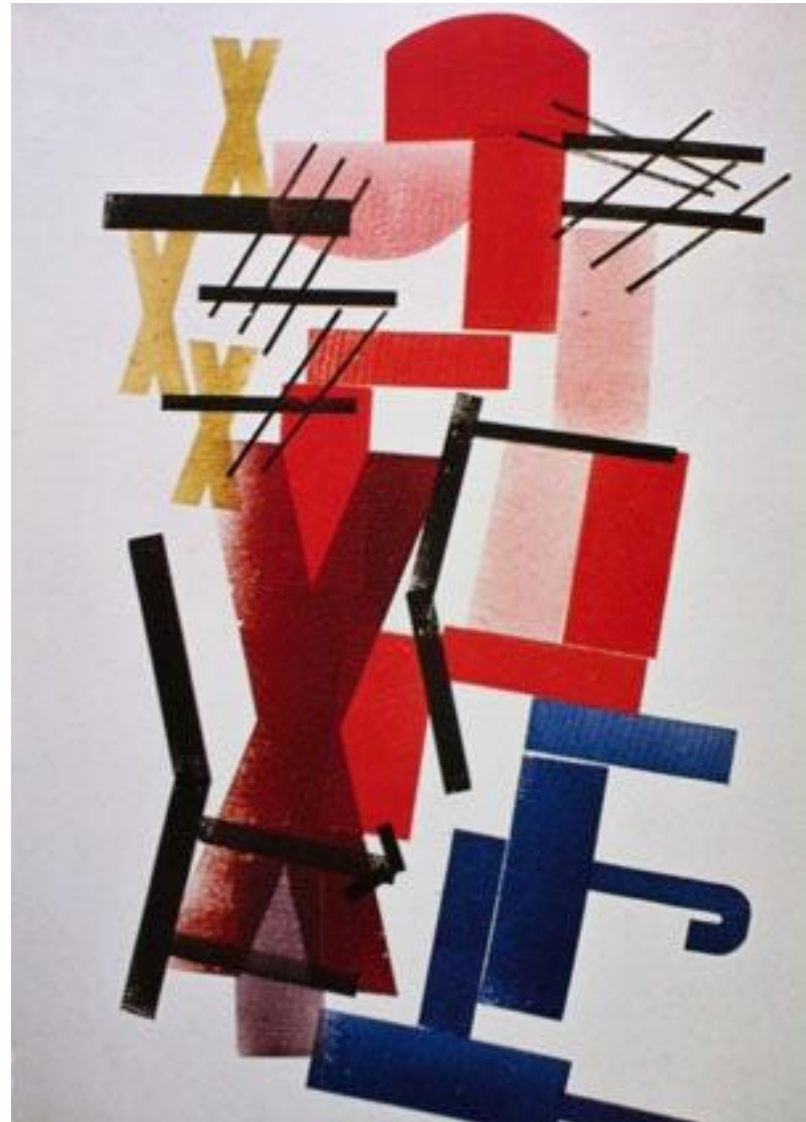

Ilustr. (84) Kompositie met letters $X$

Fonte: PURVIS, 2004, p. 52.

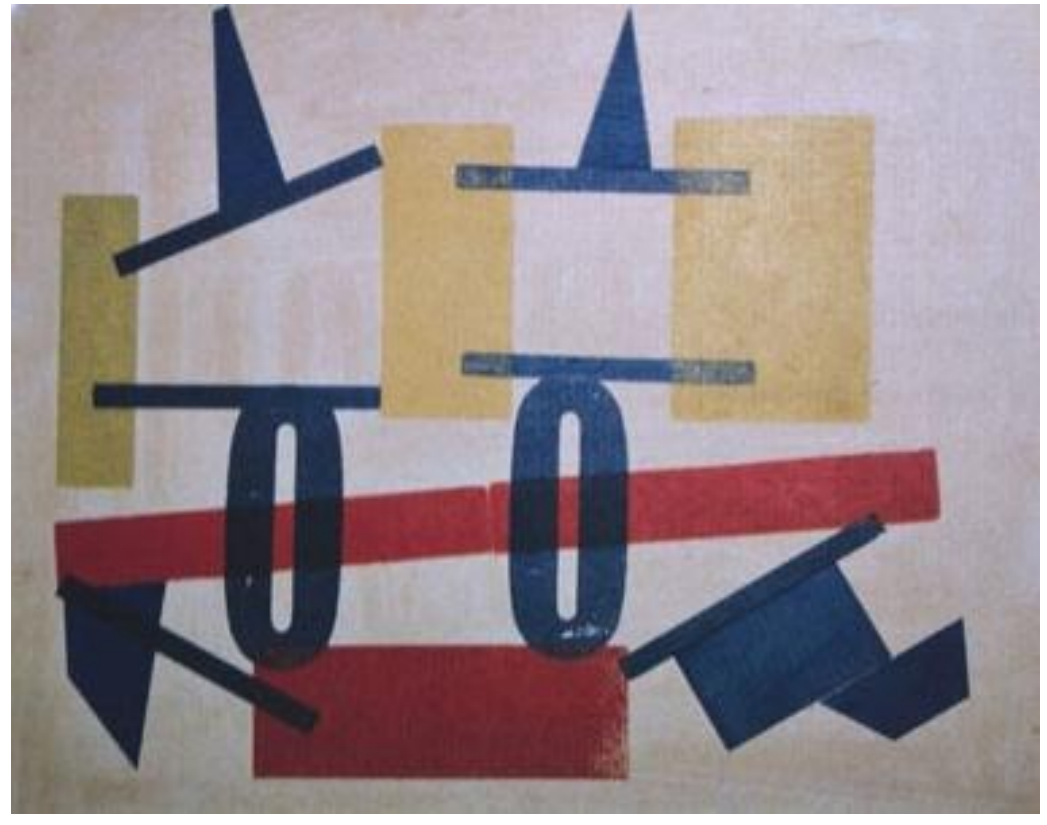

Ilustr. (85) Kompositie met letters 0

Fonte: PURVIS, 2004, p. 53. 


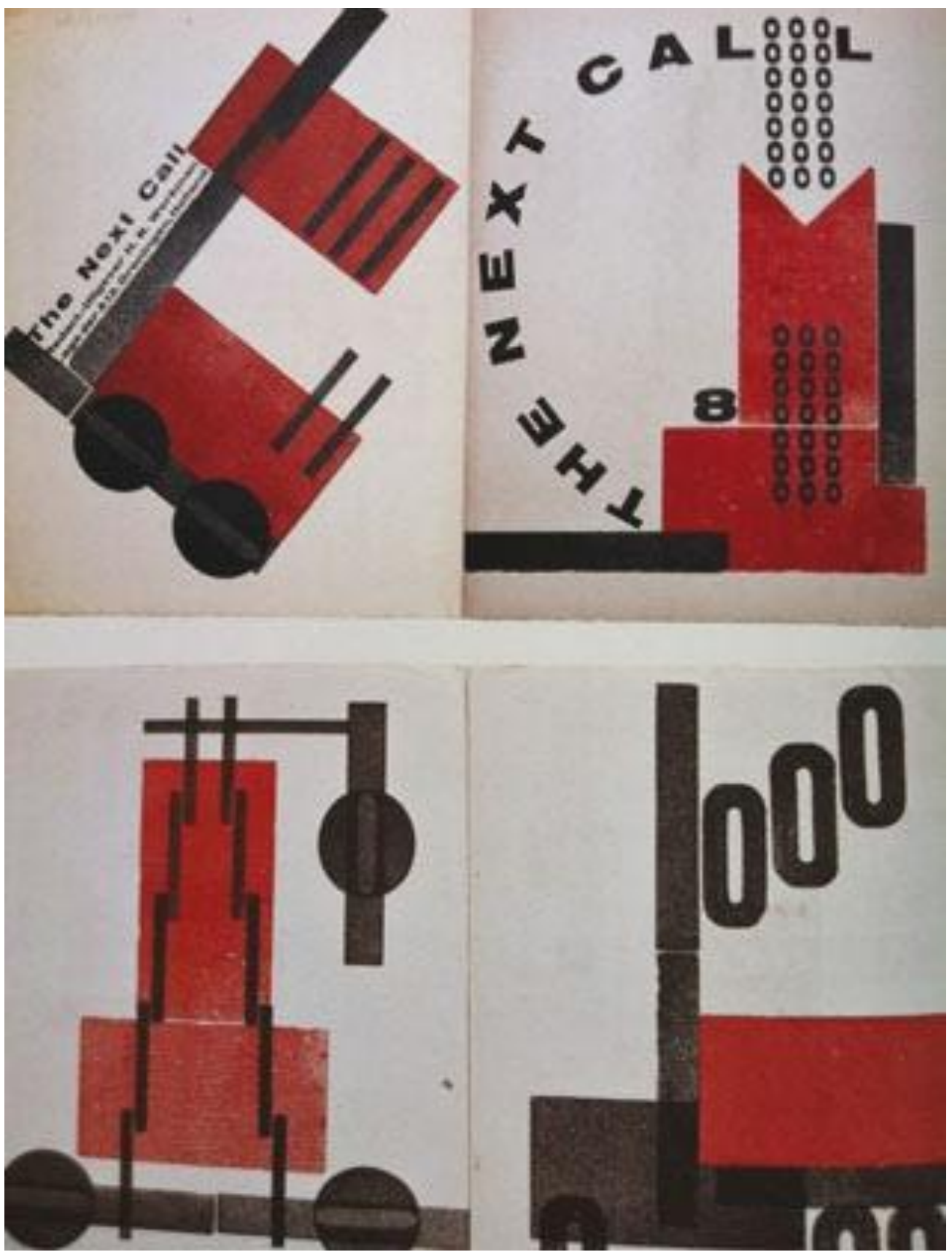

llustr. (86) The Next Call 8

Fonte: PURVIS, 2004, p. 44.

Como já fora mencionado, a experiência de Aloisio Magalhães com O Gráfico Amador é retratada por Guilherme Cunha Lima (1994) e devidamente situada no contexto histórico do design gráfico brasileiro. Nessa importante pesquisa, o autor 
nos aponta referências quanto ao contexto da linguagem das obras desse grupo junto ao panorama das artes no Brasil da década de 1950.

Em seus estudos, Lima (1994) constrói ainda uma linha cronológica que aponta que o design gráfico moderno no Brasil, apesar de iniciar-se com o movimento moderno de 1922, não resplandecia nada de moderno no sentido gráfico. A revista Klaxxon isolava-se como um dos únicos respiros legítimos a representar o movimento nesse sentido. Não se tinha além dela, algum tipo de impresso que espelhasse portanto, o design gráfico moderno.

Seguindo esse raciocício, também apontamos a vertente de algumas editoras como a José Olympio, que introduziram o trabalho de alguns modernistas como Tomás Santa Rosa a partir de 1935 - detalhado no Capitulo II da presente tese.

Ressaltamos, ainda, que foi a partir da poesia concreta, que teve grande divulgação na mídia bem como seu uso estendido à publicidade na década de 1950, que o design gráfico moderno realmente despontou.

Assim, vemos que a poesia concreta é contemporânea ao projeto d'O Gráfico Amador, apesar desse último ter sua origem diferente. Ou seja, se a poesia concreta tem sua ligação direta com a poesia, o movimento em Pernambuco tem suas origens mais próximas da literatura, em amplo sentido.

Outra diferença que se faz notar é que a escola referencial para Aloisio Magalhães n'O Gráfico Amador, no sentido de experiência visual, é a de Paris. E isso, com certeza, aliado ao caráter de estreitamento que ele tinha com a cultura brasileira, vai fazer toda diferença em seu trabalho de design a partir da década de 1960 no Rio de Janeiro.

Mas, nesse interim, outra experiência iria somar-se às mudanças no seu pensamento projetual, como relata Guilherme Cunha Lima (2003): 
Ao longo de sua existência como oficina gráfica e editora, os membros de $\mathrm{O}$ Gráfico Amador diretamente envolvidos com o design e a impressão dos livros, os chamados "mãos sujas", Aloisio, Gastão, Laurenio e Orlando, viveram uma espécie de paradoxo ou contradição permanente. Ao mesmo tempo em que tinham uma forte vocação experimental, não conseguiam se desligar de todo de uma diagramação clássica de maior aceitação pelo establishment. Esse impasse, que há de perdurar mesmo após o período de O Gráfico Amador só será rompido por Aloisio que, ao retornar de uma temporada nos Estados Unidos, muda seu estilo de diagramação para o modelo internacional propostao pela escola suíça. Cabe observar que, ha Filadélfia, Aloisio trabalhou e foi sem dúvida influenciado por Eugene Feldman, da The Falcon Press, com quem realizou dois livros: Doorway to Portuguese e Doorway to Brasília. (LIMA in LEITE, 2003, pp. 92 - 93, grifo do autor) 


\section{CAPÍTULO IV}

\section{ALOISIO MAGAHÃES E EUGENE FELDMAN}

O capítulo que se apresenta tem como objetivo explorar e debater a produção de dois livros, cuja produção marcou o encontro de Aloisio Magalhães com o artista gráfico, Eugene Feldman (1921 - 1975) na Filadélfia, EUA no final da década de 1950. O primeiro livro, Doorway to Portuguese foi realizado em 1957 e o segundo, Doorway to Brasilia, em 1959, registrando a construção da nova capital do Brasil no então governo do presidente Juscelino Kubitschek.

Aloisio Magalhães viaja em 1956 aos Estados Unidos interessado em conhecer o museu de Filadélfia, nomeado em sua fundação como Pennsylvania Museum \& School of Industrial Art, o que retratava à época, ainda no século XIX, a noção de artes industriais.

Em 1930, o imigrante russso Alexey Brodovitch (1898 - 1971), designer gráfico e um dos mais importantes e influentes editores de arte da revista Harper's Bazaar, foi convidado pela instituição do museu escola a implantar um departamento 
de design publicitário. Isto concedeu à escola, o que Brodovitch já havia realizado em Nova York com o design gráfico da revista, isto é, agregou um caráter experimental nas pegadas do modernismo europeu.

Foi em 1956 que Eugene Feldman, então fundador da The Falcon Press, tornou-se diretor do Departamento de Design Tipográfico. Além de contribuir com seu trabalho experimental à escola, fazia de sua gráfica um verdadeiro laboratório. Dividia o trabalho comercial com 0 trabalho investigativo a partir das novas tecnologias de impressão, sistema na época ainda chamado de litografia foto-offset.

Quando visitou o museu, Aloisio Magalhães acabou conhecendo a sua escola. O seu interesse despertou o convite do então diretor E.M. Benson que the propôs permanecer por cerca de dois meses como professor convidado.

Nesse período, Aloisio visita o Print Club em Filadélfia onde Eugene Feldman estava realizando um exposição com o que investigava no campo das novas tecnologias de impressão. Segundo Leite (2003, p. 95), "[...] teve início uma forte e profícua amizade, que veio a render experimentos notáveis no campo do design editorial". Aloisio Magalhães ainda voltaria a lecionar na escola, sob o nome de Philadelphia Museum School of Art em 1959 e em 1962.
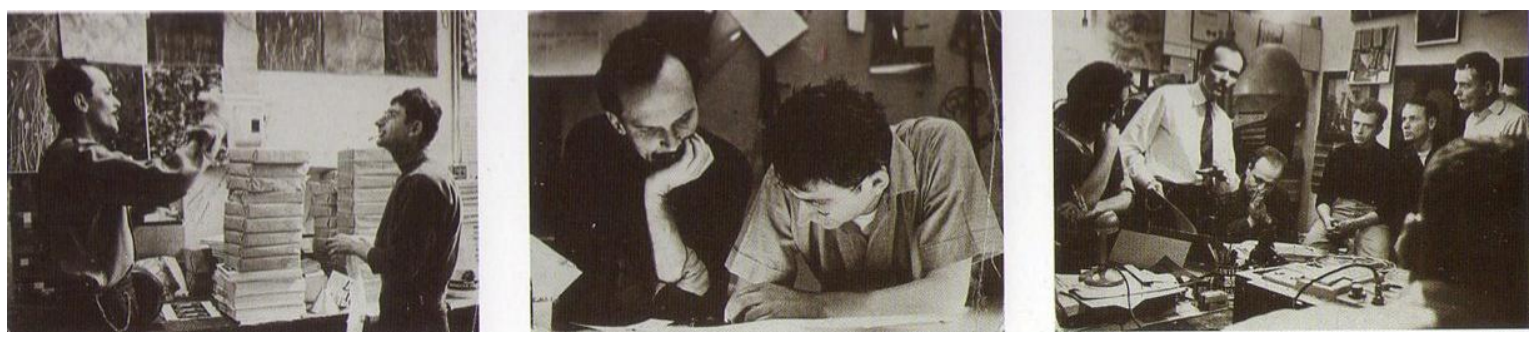

Ilustr. (87) Aloisio Magalhães e Eugene Feldman na The Falcon Press Fonte: LEITE, 2003, p. 95 


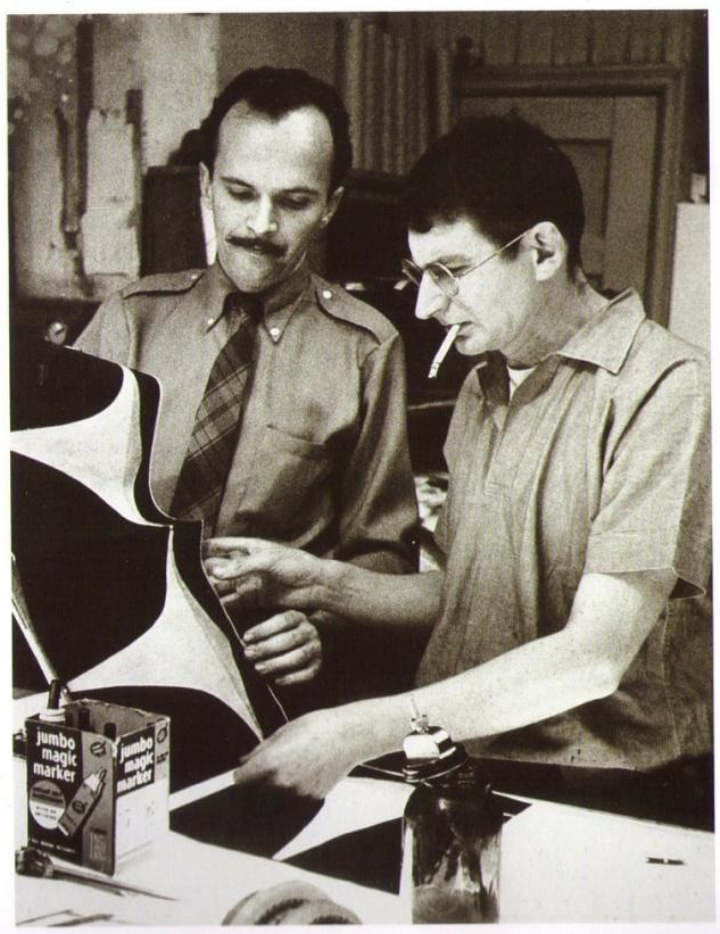

Ilustr. (88) Aloisio Magalhães e Eugene Feldman na The Falcon Press

Fonte: LEITE, 2003, p. 95.

Como fruto maior da viagem de Aloisio Magalhães à Filadélfia, podemos apontar alguns pontos de extrema valia para a sua carreira enquanto designer, iniciando pelo seu contato com o então chamado estilo internacional, surgido na Suíça e que teve acentuada produção entre os anos de 1950 e 1970.

Esse movimento era ligado à corrente artística modernista e tinha como característica a padronização da forma visual através da informação contida, simples e concreta; concentrava-se em uma linha de exposição racional e eliminava qualquer tipo de interferência visual; tinha como objetivo maior, pelo seu discurso, a compreensão universal. Foi uma vertente do Funcionalismo que, por sua vez, propunha enquanto atitude de expressão, o princípio de que "a forma segue a função". Estendeu-se ao campo da arquitetura onde encontramos o nome de Le Corbusier. 
No design, vemos que as principais características desse estilo se aplicam à clareza, nos layouts estruturados com seus grids à base de proporções simétricas, no uso do minimalismo e da máxima de funcionalidade para a compreensão da mensagem. Também vemos dentre todas estas características, o emprego da fotografia com uso bem objetivo e preciso na construção do sentido da informação. Não foi por acaso que as grandes coorporações adotaram esse estilo, não somente em sua identidade, como também no desenvolvimento de seus produtos.

No campo da tipografia, vemos a caracterização de uma tipografia que deveria ser universal e neutra, compreensível e funcional. As fontes que encontramos nesta época, em sua maioria, destituiam-se das serifas, eram visualmente simples e de pesos harmoniosos. A Helvetica, de Max Miedinger e a Univers, de Adrian Frutiger são representantes legítimas desta época.

No que compete aos textos, vemos que a diagramação da página, com suas formulações de grid, priviligiavam os blocos alinhados e não mais a justificação. Estava presente e dissiminado no campo do design, o Estilo Internacional.

Mas fica a questão: pelo que realmente Aloisio Magalhães, nessa passagem pelos Estados Unidos, iria se deixar influenciar? Como apontamos, o estilo internacional estendia-se aos mais variados campos do impresso e migrava para outros cantos do mundo como referência a ser adotada.

Importante lembrar que, nesse período, Aloisio Magalhães encontrava-se em pleno desenvolvimento de sua linguagem gráfica junto d'O Gráfico Amador, como foi discutido no capítulo terceiro desta tese. Mas, em sua visita à Filadélfia, encontrou um artista que the abriu ainda mais o caminho para que continuasse sua especulação no campo gráfico. 
Se por um lado Aloisio Magalhães deparou-se com um estilo empregado no design gráfico - nos meios de comunicação impressa, publicidade e identidade corporativa - por outro lado, ele introjetou-se em uma cultura de ensino de design que era voltado ao conhecimento das artes associado aos ofícios industriais. Nas palavras de Leite (2006, p. 221):

[...] a historiografia do design teve sempre por hábito o enquadramento dos eventos segundo a lógica do design modernista, obsessivamente tomado pelo como balizamento absoluto e definitivo [...] no entanto, o percurso pelo qual as atividades projetivas são introduzidas nos Estados Unidos sinaliza para uma perspectiva, digamos mais harmônica, em que o conhecimento das artes associado aos ofícios pré-industriais garantem uma maior integração ao desenvolvimento sócio-econômico [...] algumas publicações norteamericanas, de 1880 a 1930, dão conta da preocupacão com os rumos da industrialização nos Estados Unidos, traduzida pela repercussão do movimento inglês de Arts and Crafts e do trabalho do escritor, designer e artesão socialista inglês William Morris (LEITE, 2006, p. 221)

Faz-se necessário dizer que, além desta vertente conceitual empregada nos campos do ensino das artes e do design - mais harmoniosa frente à outras culturas e integradora no ponto de vista do desenvolvimento humano - vemos que o contato que Alosio manteve junto à escola da Filadélfia Ihe trouxe esta percepção. Isto é, o convite para lecionar nesta instituição foi cabível pelo entendimento desses pressupostos por parte de seu diretor, que acreditava ser de extrema valia a contribuição de um artista brasileiro para o desenvolvimento de uma disciplina em artes. Mas devemos nos ater ao fato desta escola também possuir em seus moldes acadêmicos uma flexibilização quanto à experimentação, o que propiciou um 
caminho de continuidade a trajetória de Aloisio Magalhães ao campo da linguagem gráfica.

Foi no encontro com Eugene Feldman que esta possibilidade tomou corpo, não somente por estar a frente do Departamento de Design Tipográfico do Philadelphia Museum School of Art, mas, principalmente, por ser ele a representação mais aguda do que se podia encontrar ali naquele momento enquanto artista gráfico experimental.

A isto, soma-se a possibilidade encontrada na The Falcon Press e as novas tecnologias de impressão, o que fez desse espaço um verdadeiro campo de especulação criativa desses dois artistas.

Em uma primeira análise, vemos que Aloisio Magalhães se preocupou em perceber as nuances do aspecto gráfico que poderiam ser alcançados e que davam o linear da linguagem estabelecida a esse sistema de impressão. Trabalhou a pura investigação, nesse sentido, deixando transcorrer o experimento bem como sua expressividade.

É preciso dizer também que, a essa altura, Eugene Feldman possuia um bom domínio da técnica que utilizava, o offset - ainda chamado à época de litografia fotooffset. Trabalhava de modo a interagir com o sistema, explorando-o de uma forma não convencional, principalmente no que se refere à gravação das chapas matrizes $^{31}$. Ao invés de utilizar cada chapa em sua função tradicional, como meio de separação de cores para impressão em quadricromia, por exemplo, ele intervinha na matriz de modo a criar variações e nuances que transformavam a imagem original

\footnotetext{
31 Offset é um sistema de impressão indireta. Ou seja, realizada a partir da gravação de chapas présensibilizadas à luz ultravioleta (separadas por cor e grau de inclinação da retícula), dispostas cada uma em um conjunto de cor na máquina impressora. A imagem reproduzida na chapa é transferida para a blanqueta que, por último, a transfere para o papel. Daí o termo impressão indireta. A parte de pré-impressão é o conjunto de tarefas na produção gráfica que antecede a impressão. No caso da offset, é a imposição do filme nas chapas, sua gravação e revelação (para cada cor, têm-se uma chapa com a densidade e distribuição cromática).
} 
em algo totalmente diferente do que resultaria uma impressão tradicional. Ou seja, ele via como possibilidade de linguagem a não fidelização da reprodução da imagem fotográfica, dando vazão às possibilidades interpretativas.

Conhecia os princípios desta tecnologia e a partir disso alterava seus padrões na reprodução, gravação e impressão das imagens. Tinha uma linguagem gráfica fluída, com movimento, longe de uma representação estática. Trabalhava uma mesma imagem com variação de cor e sobreposição, ou seja, com certa folga na precisão do registro das cores, provocava deslocamentos nas imagens, o que conferia ao trabalho um jogo ritmico na delineação dos objetos e na formulação de uma concepção estética. Nas palavras de Aloisio Magalhães, "[...] para ele a gráfica e seu equipamento tecnológico eram instrumentos, ferramentas que ele utilizava como alguém usa um lápis , ou como alguém mais que usa uma pena ou um pincel [...] utilizava o aparato tecnológico sem etapa intermediária". (MAGALHÃES in LEITE, 2003, p. 96).

Eugene Feldman tinha, nesse curso de exploração de sua linguagem, o caminho das impressões individuais. O seu trabalho era marcado por séries de impressão, como um artista de gravura que desenvolve alguns temas com variações. Isto é, para Feldman o trabalho criativo concentrava-se nestas chamadas prints e era algo que contínuo, interminável segundo o próprio Aloisio:

[...] ele nunca esteva interessado no fato de que as folhas seriam reproduzidas muitas e muitas vezes. Ao invés disso, ele estava sempre introduzindo novas coisas. Estava sempre mudando uma chapa ou colocando um novo elemento no processo de offset bem no meio de uma tiragem. Ele manipulava uma alta e sofisticada tecnologia com completa liberdade. Seu uso da mídia era paradoxal porque continuava a fazer mudanças mesmo ao ponto de ir de encontro à tecnologia. Ele utilizava a tecnologia da reprodução em 
offset como ferramenta para fazer imagens únicas a partir de materiais e métodos que não tinham nada a ver com os materiais e métodos comuns da tecnologia. Esse é um aspecto muito importante da mentalidade de Gene, da sua abordagem à sua tecnologia (MAGALHÃES in LEITE, 2003, p. 98)

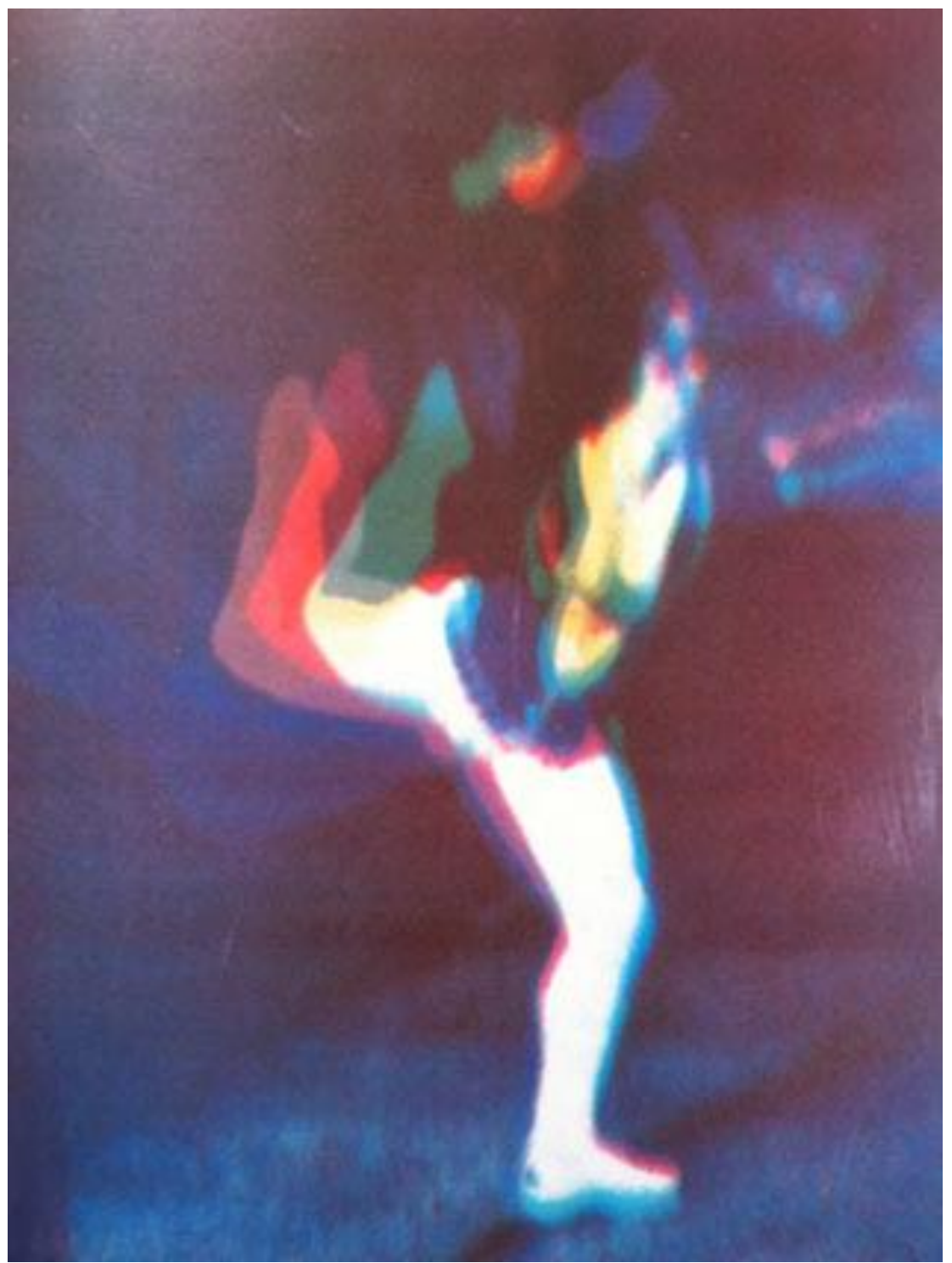

Ilustr. (89) Detalhe do bailarino russo Rudolf Nureyev Impressão de Eugene Feldman Fonte: LEITE, 2003, p. 96. 

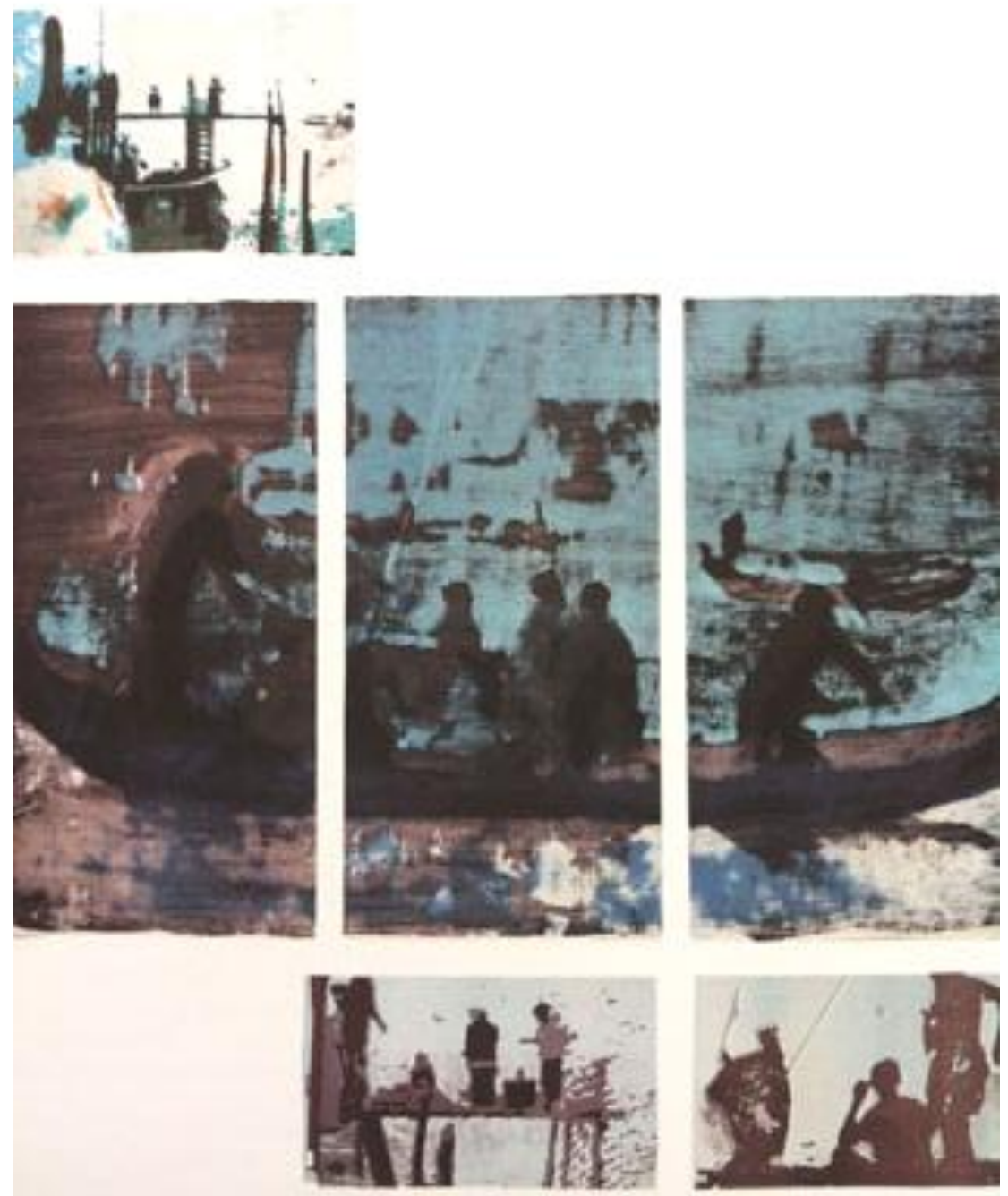

Ilustr. (90) Quatro exemplares de uma série sobre Veneza

Impressão de Eugene Feldman

Fonte: LEITE, 2003, p. 101.

No que se refere a exploração da linguagem gráfica, Aloisio Magalhães estabeleu certos elos entre o que estava realizando n'O Gráfico Amador e o que veio a conhecer com Feldman. Um ponto específico que podemos citar é o desenho diretamente na chapa de impressão, algo que Aloisio o fizera nos livros Pregão Turístico do Recife (1955), de João Cabral de Melo Neto e Memórias do Boi Serapião (1955), de Carlos Pena Filho como podemos verificar nas ilustrações (91) e (92). 


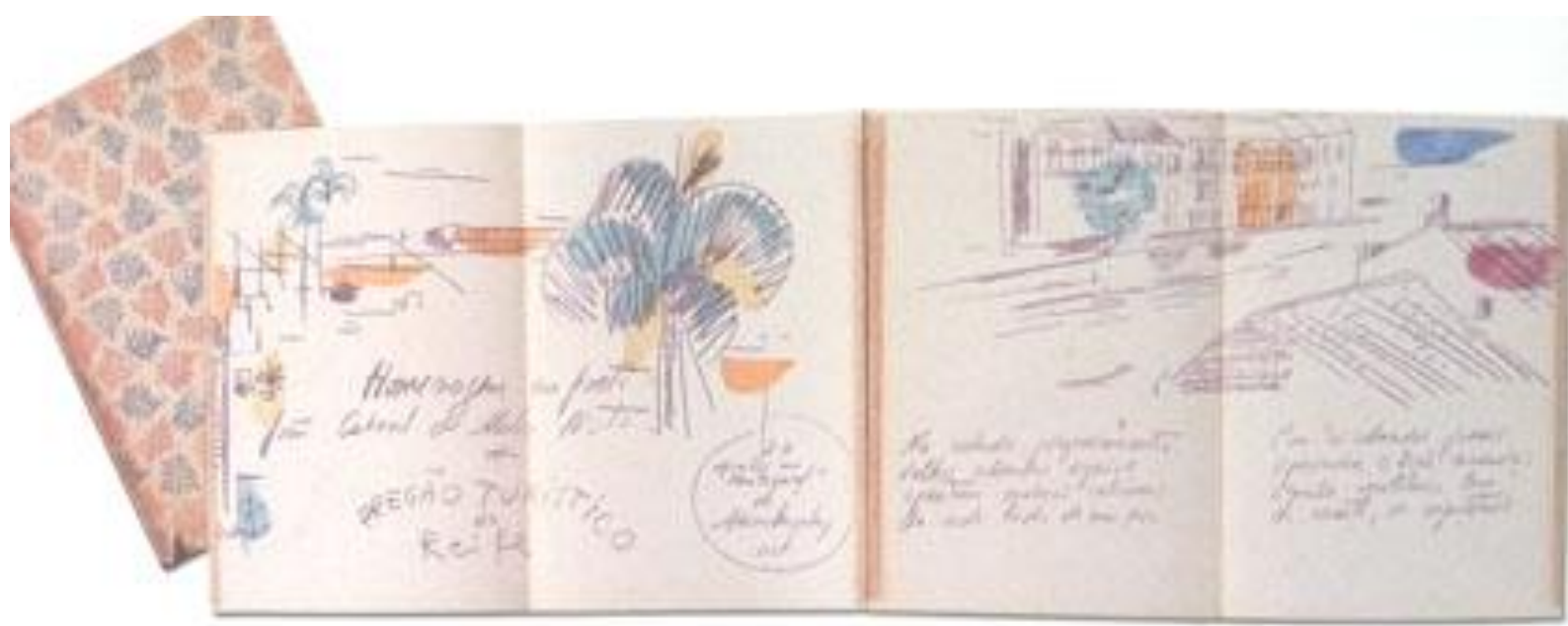

Ilustr. (91) Pregão Turístico do Recife. João Cabral de Melo Neto. O Gráfico Amador, Recife, 1955. Fonte: LEITE, 2003, p. 86.

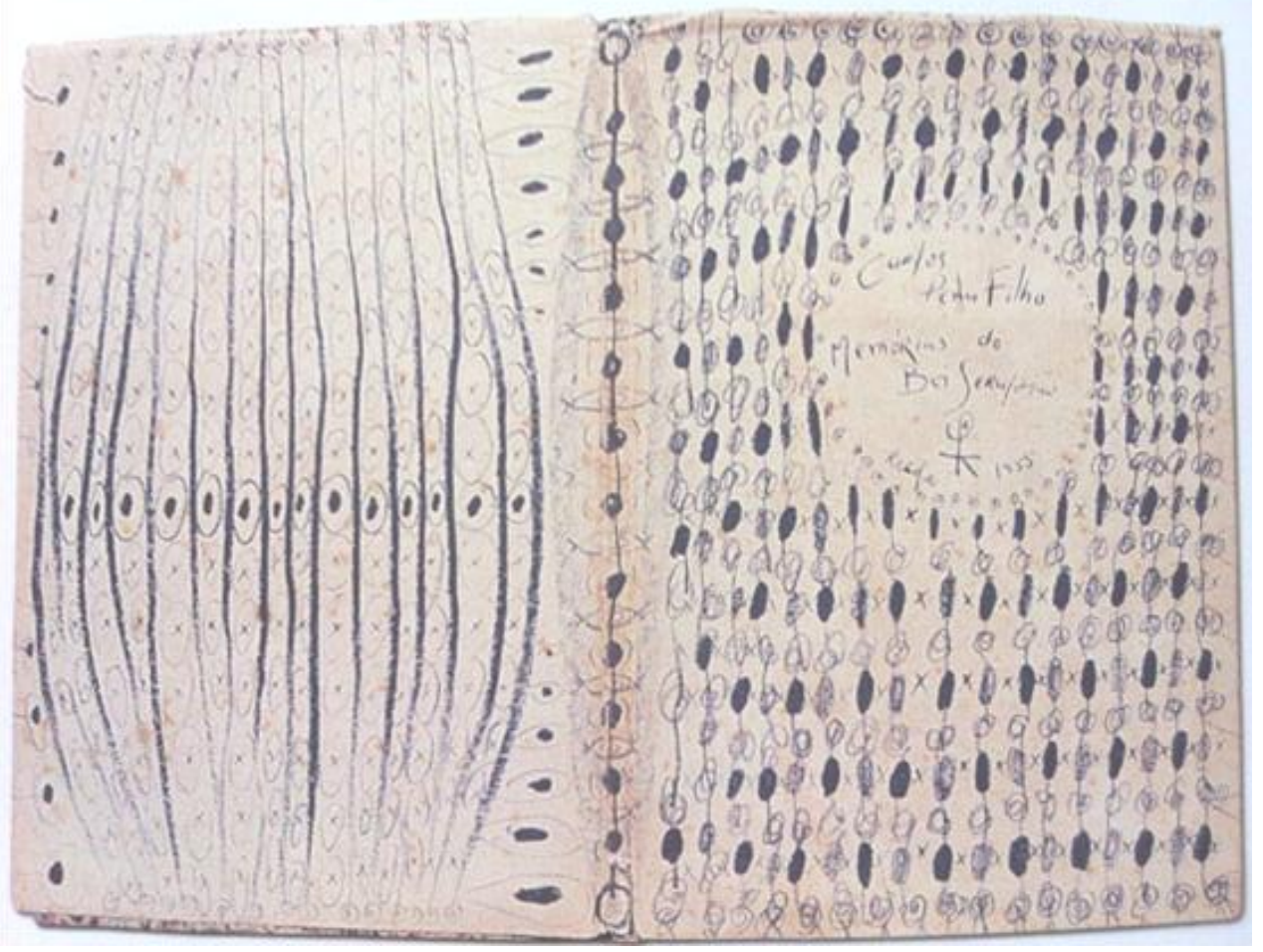

llustr. (92) Memórias do Boi Serapião. Carlos Pena Filho.

O Gráfico Amador, Recife, 1955

Fonte: LEITE, 2003, p. 90. 
Outra questão importante relaciona-se com o diverso repertório de materiais que Aloisio explorava em seus trabalhos aliado às técnicas de impressão mista. Isto é, fora o papel e a tinta, somavam-se o recorte de máscaras - pochoir, o linóleo, as texturas das próprias matrizes assim como alguns instrumentos que eram subvertidos à ordem como a espátula, pincel, tiras de papel amarrado, estilete e até mesmo um copo que em uma das páginas do livro Doorway to Portuguese, serviu para decalcar e formar uma espécie girassol na página "G" como vemos na ilustração abaixo:

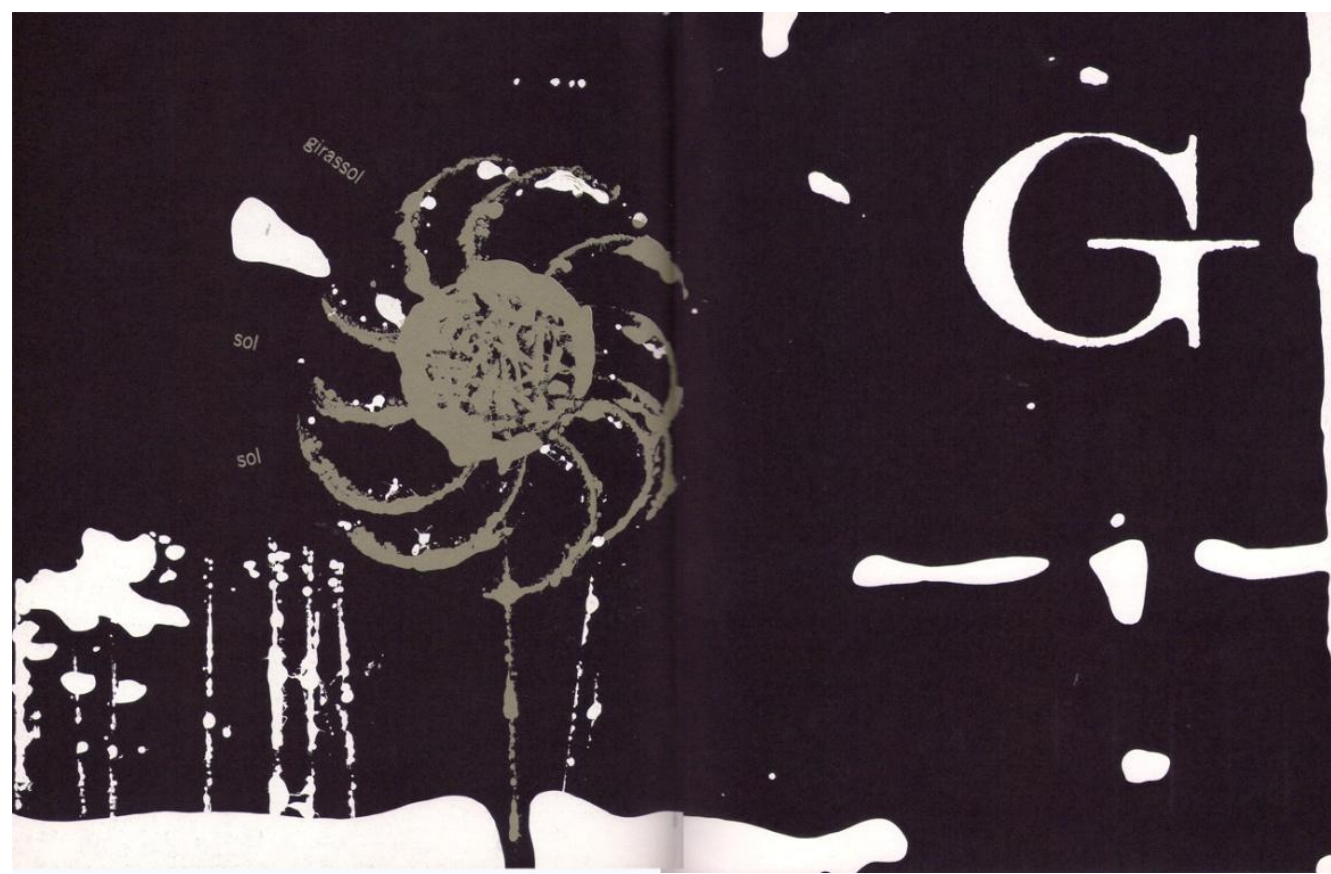

Ilustr. (93) Página G do livro Doorway to Portuguese, 1957

Fonte: Eugene Feldman e Aloisio Magalhães

Aloisio Magalhães encontra na figura de Feldman dentro de seu processo artístico, a relação que sempre o norteou quanto ao processo de trabalho. Isto é, o modo de criar, de conceber, construir e projetar estabelecia-se a partir da vivência, 
do próprio fazer. O que para Feldman também estava próximo de seu entendimento dentro do que ele se propunha frente ao processo de produção de seu trabalho. Quanto aos materiais e a tecnologia, Feldman e Aloisio em muito se aproximavam. Tinham a observação, o cuidado e respeito diante deles e de suas possibilidades, o que Ihes concedia um grau de estreitamento com os mesmos e a dinâmica para a articulação da linguagem. Nas palavras Feldman, vemos esse contexto:

[...] o homem pode fazer arte com uma máquina; tanto a impressora offset quanto uma prensa manual podem ser seus pincéis. Tentei utilizar minhas máquinas como um pintor o faz com seus pincéis. Minhas tintas são meus gouaches ou óleos e o papel, a minha tela. Nas artes gráficas, como em qualquer outro ofício ou arte, é necessário o respeito pelos materiais. Penso que este respeito induz ao desejo de explorar, de aprender o que a justaposição de tipos, linha, cor, espaço e fotografia pode criar [...] eu realmente sei que tenho uma compulsão por investigar a relação dos elementos da impressão entre si, por mudar essas relações e rearrumá-las para experimentar com o processo [...] as máquinas, tanto a impressora offset quanto a prensa manual, são extensões das mãos e talento dos homens. Certamente, daqui a 20 anos nossas técnicas serão diferentes. A impressão poderá ser feita eletronicamente, mas seu projeto e sua composição continuarão a apresentar desafios estéticos. Os materiais, seja um tipo de chumbo ou um tubo eletrônico, deverão ambos merecer respeito (FELDMAN in LEITE, 2003, p. 100)

Ainda decorrendo de uma análise das aproximações e distanciamentos entre as linguagens desses dois artistas, vemos que o projeto dos dois livros em questão, impressos à época, Doorway to Portuguese e Doorway to Brasilia, marcam uma mudança no processo de criação e produção de Eugene Feldman. 
Como já fora apontado, Feldman tinha como principal vetor de criação, a produção contínua nas séries que desenvolvia, e assim, mantinha um curso dentro de sua especulação artística espelhada por sua produção, as prints. A maneira com que ele construia e expandia sua linguagem, através desse tipo de lógica, difere da dinâmica da construção de um projeto editorial.

Aloisio Magalhães relata, "[...] por que ele produziu tão poucos livros? Em meu ponto de vista, a resposta baseia-se em uma questão bem interessante sobre seu processo criativo. Produzir um livro exige um momento de parada." (MAGALHÃES in LEITE, 2003, p. 98).

Para Feldman, Aloisio contribuiu não só pela troca nas experiências no campo das artes gráficas, no intercambiamento das técnicas e o contexto cultural de sua linguagem, mas, principalmente, na ideia de trabalhar na dinâmica do projeto editorial, algo que estava familiarizado junto a'O Gráfico Amador. Mas a experiência com o livro não se deu de imediato.

A obra Doorway to Portuguese (1957) não teve um plano editorial, foi feita a partir da reunião de uma série de impressões experimentais que foram selecionadas a partir de um critério adotado pelos artistas. Aloisio introduziu a ideia de colocar pequenos textos em português baseado no princípio do ABC (abecedário) com uma organização interna bem solta e uma rica diversidade de intervenções gráficas no sistema offset. Esse livro ganhou três medalhas de ouro do Art Directors Club da Filadélfia. 


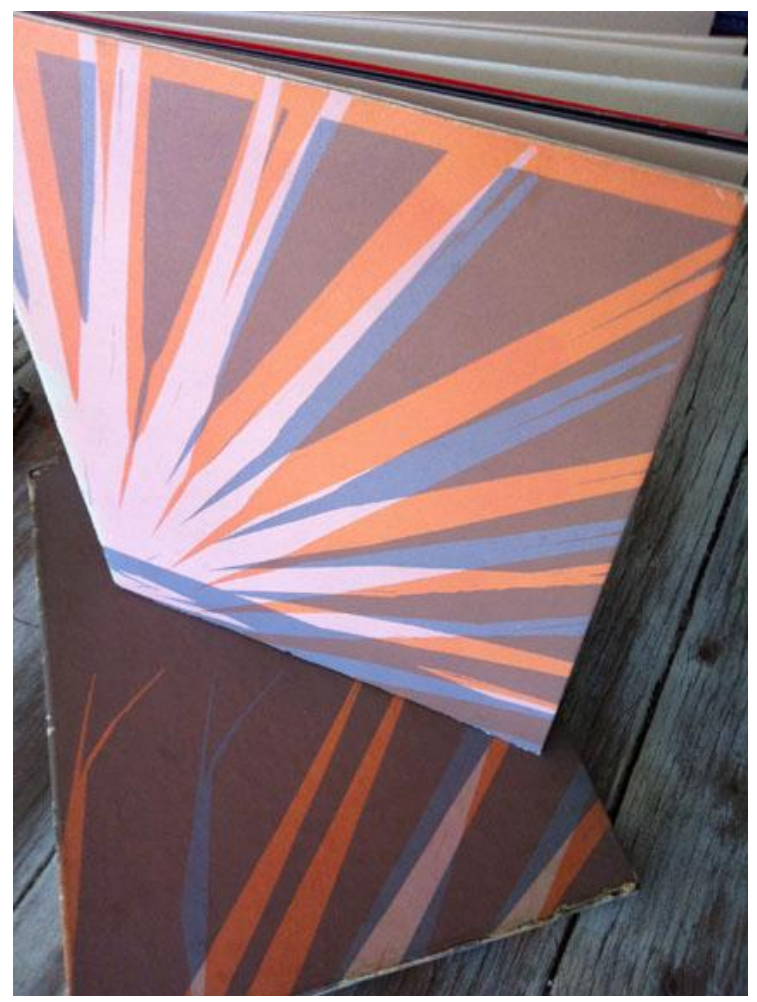

Ilustr. (94) Doorway to Portuguese, 1957.

Fonte: Aloisio Magalhães e Eugene Feldman.

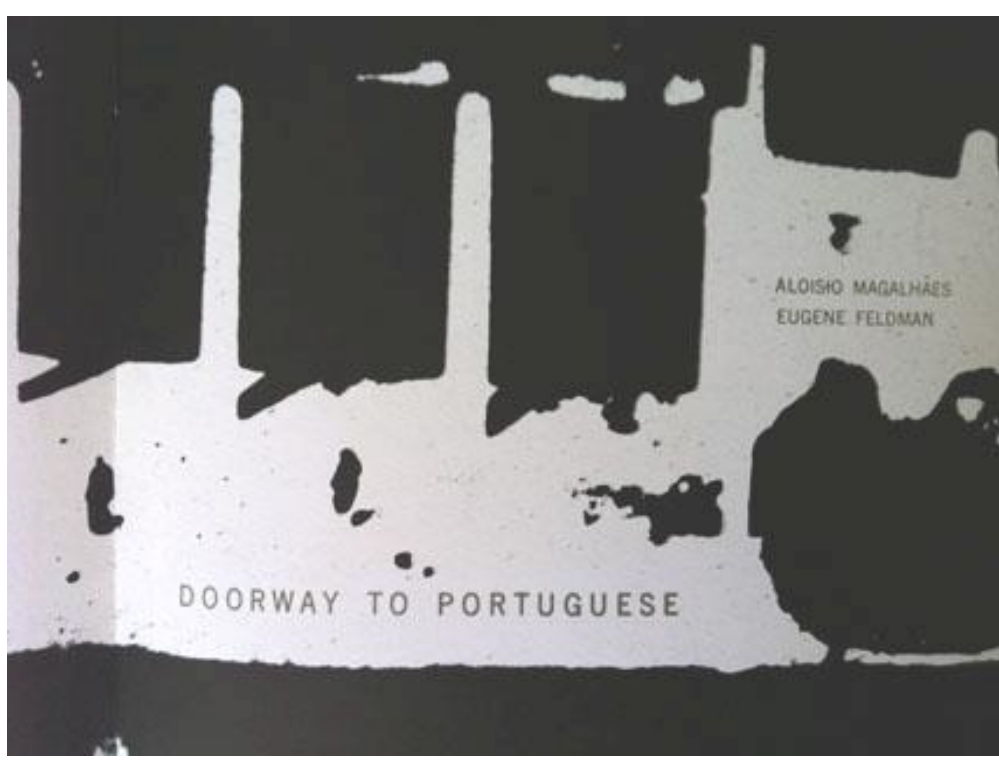

Ilustr. (95) Doorway to Portuguese, 1957.

Fonte: Aloisio Magalhães e Eugene Feldman. 
Diferente do primeiro, Doorway to Brasilia (1959), possui um projeto editorial bem mais estruturado e com a formatação de livro mais programado. Isto é, analisando a obra, vê-se que ela tinha um projeto de criação e edição, e deveria atender a um contexto além das experiências pessoais dos dois artistas. Nas palavras de Aloisio, "[...] vamos usar esse evento, dissemos, o fato de uma nova capital estar sendo construída, para vermos o que podemos tirar de lá e utilizar na tecnologia de impressão [...] decidimos tirar fotografias no Brasil e então fazer algo criativo." (MAGALHÃES in LEITE, 2003, p. 98 -99).

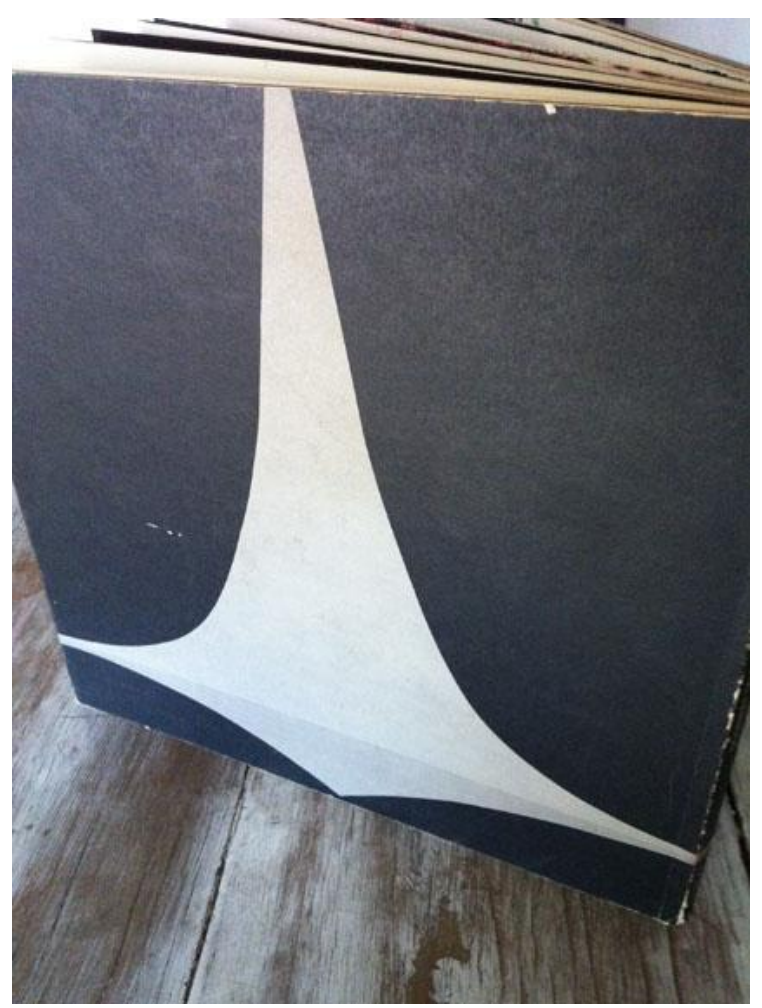

llustr. (96) Doorway to Brasilia, 1959.

Fonte: Aloisio Magalhães e Eugene Feldman. 


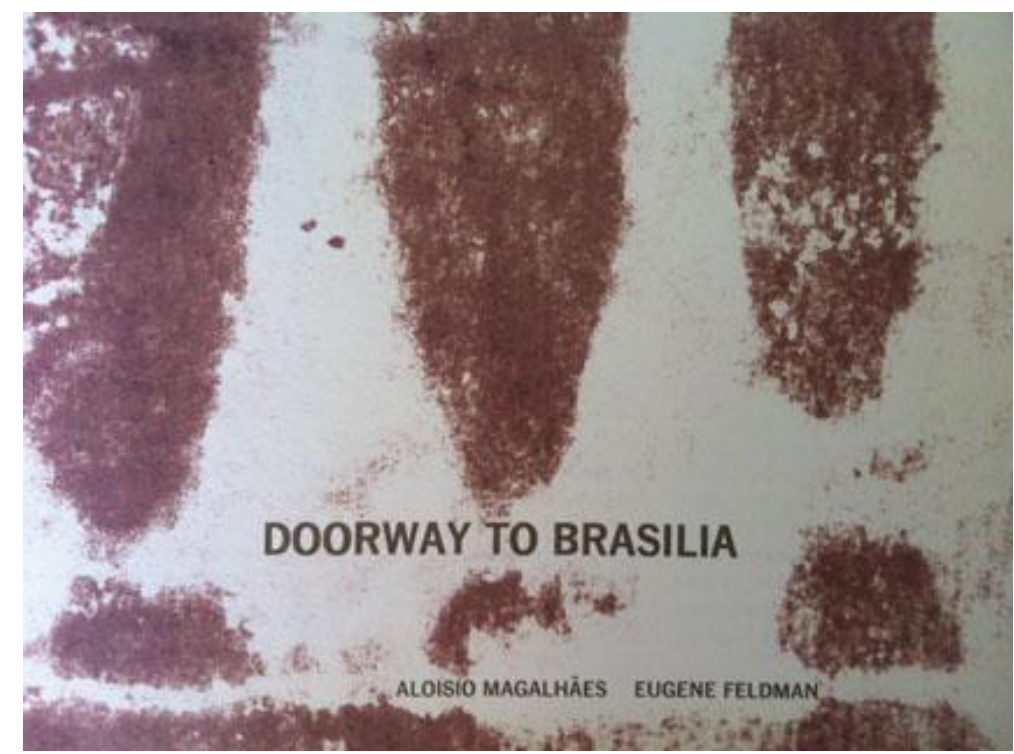

Ilustr. (97) Doorway to Brasilia, 1959.

Fonte: Aloisio Magalhães e Eugene Feldman

O livro possui uma maturidade de linguagem quanto ao projeto editorial e às técnicas utilizadas pelos artistas, assim como uma lógica de narrativa mais delineada. Cabe lembrar, que esse projeto tinha como intenção, retratar a construção de Brasilia. No destaque da ilustração (98) vemos Aloisio Magalhães, Eugene Feldman e o presidente Juscelino Kubitschek. Na ilustração (99), Aloisio Magalhães e Eugene Feldman em visita à construção de Brasília.

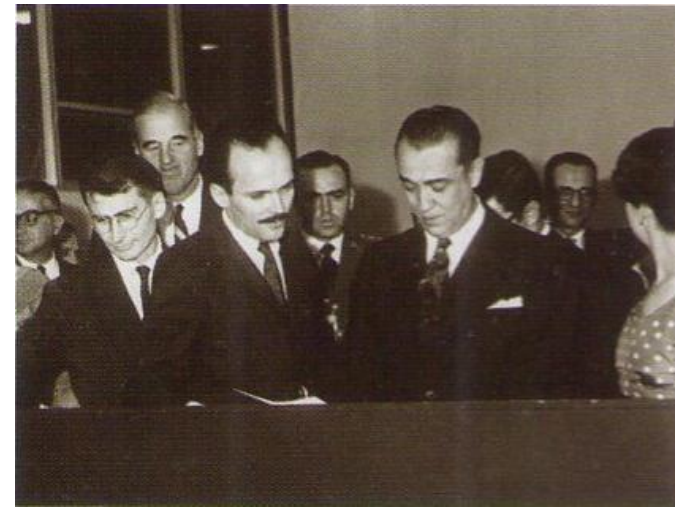

llustr. (98) Aloisio Magalhães Fonte: LEITE, 2003, p. 111.

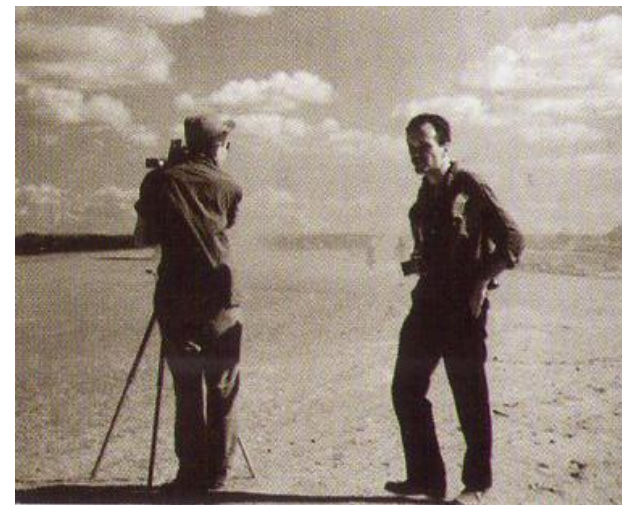

llustr. (99) Aloisio Magalhães Fonte: LEITE, 2003, p. 110. 
Partindo de um olhar técnico, as obras Doorway to Portuguese e Doorway to Brasilia foram analisadas com intuito de melhor compreendermos os caminhos percorridos para a elaboração da linguagem gráfica que compoe tais obras, bem como os recursos utilizados por Aloisio Magalhães e Eugene Feldman nessa experiência vivida por ambos na The Falcon Press.

O ponto principal percebido nessa análise, como já citado anteriormente, foi o trabalho na pré-impressão com diversos modos de intervenção na gravação das chapas de offset.

Eugene Feldman conhecia muito bem o processo e isso lhe permitiu trabalhar com tons contínuos seguindo o princípio de utilizar a mesma imagem, mas com diferentes tempos de exposição do filme à chapa na mesa de luz. Isto conferia a imagem uma diferenciação quanto a quantidade de grafismo presente na chapa. Ou seja, trabalhou nos dois livros na maioria das páginas, com dois tons para a mesma figura, sendo a primeira cor (com grafismo mais granulado para tons claros) com exposição menor e a segunda cor (com grafismo mais presente) com maior exposição da chapa à luz como podemos ver nas imagens a seguir: 


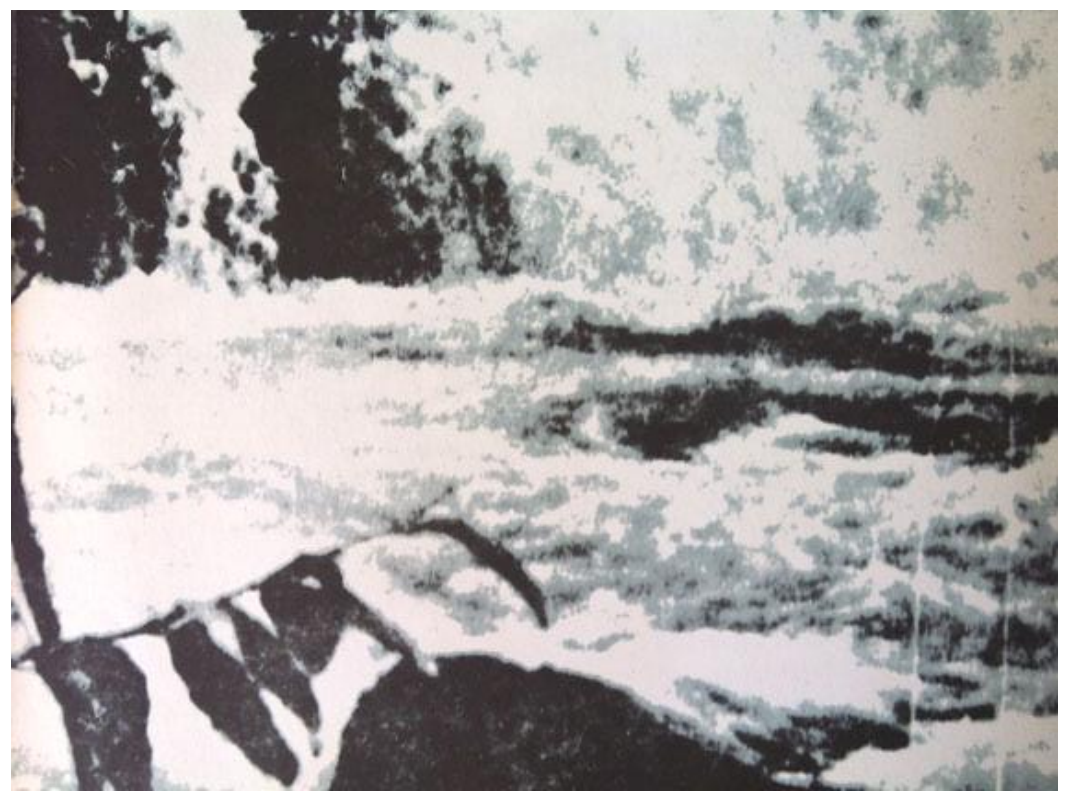

Ilustr. (100) Página do livro Doorway to Brasilia, 1959.

Fonte: Aloisio Magalhães e Eugene Feldman

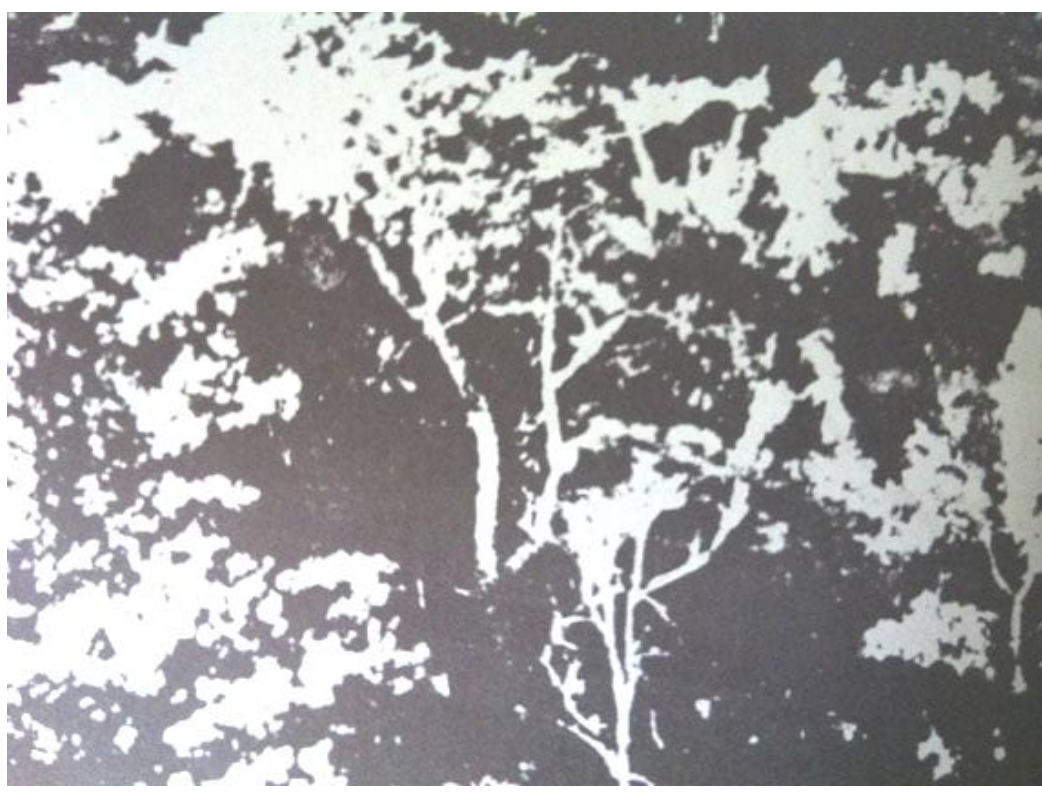

Ilustr. (101) Página do livro Doorway to Brasilia, 1959.

Fonte: Aloisio Magalhães e Eugene Feldman 
Outro dado importante é o proposital deslocamento da imagem alcançado pelo registro não exato das duas cores (ou mais). Ou seja, a sua linguagem gráfica trabalhava esse tipo de estética, e desse modo, o processo de reprodução da imagem alinhava-se a esse conceito. Tanto que ao realizarmos a análise dos livros, constatamos também, que há uma diferença de tamanho entre os dois filmes. Isto é, além de estarem deslocados - fora de registro -, existe o artifício do trapping. Técnica conhecida para expandir o limite de uma figura em relação à outra de modo a haver uma pequena sobreposição na junção de ambas. No caso do trabalho de Feldman, ele expandia uma das cores em relação à outra (na mesma imagem) como podemos verificar com atenção na imagem abaixo:

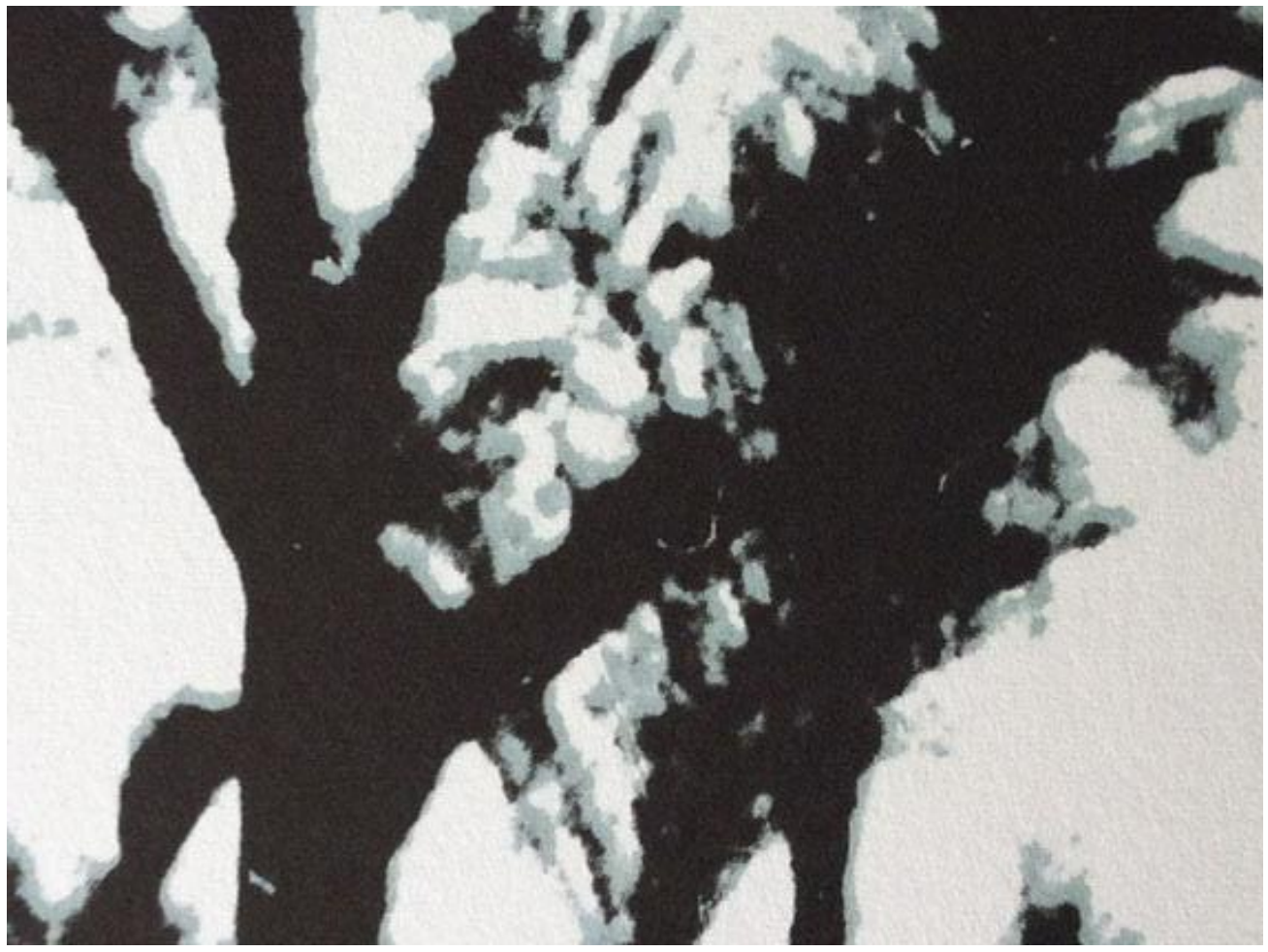

Ilustr. (102) Página do livro Doorway to Brasilia, 1959. 
As imagens utilizadas nos dois livros (e isso era uma das características do trabalho de Eugene Feldman) eram feitas com alta ampliação ${ }^{32}$ conferindo às formas, aos objetos, uma particularidade em seu delineamento. Desse modo, junto aos artifícios de sobreposição de cor, criavam um jogo poético com a imagem que era sugestionada e não seguia contornos precisos. Isso se exemplifica na maioria das páginas do livro Doorway to Brasilia como podemos ver nas imagem que seguem:

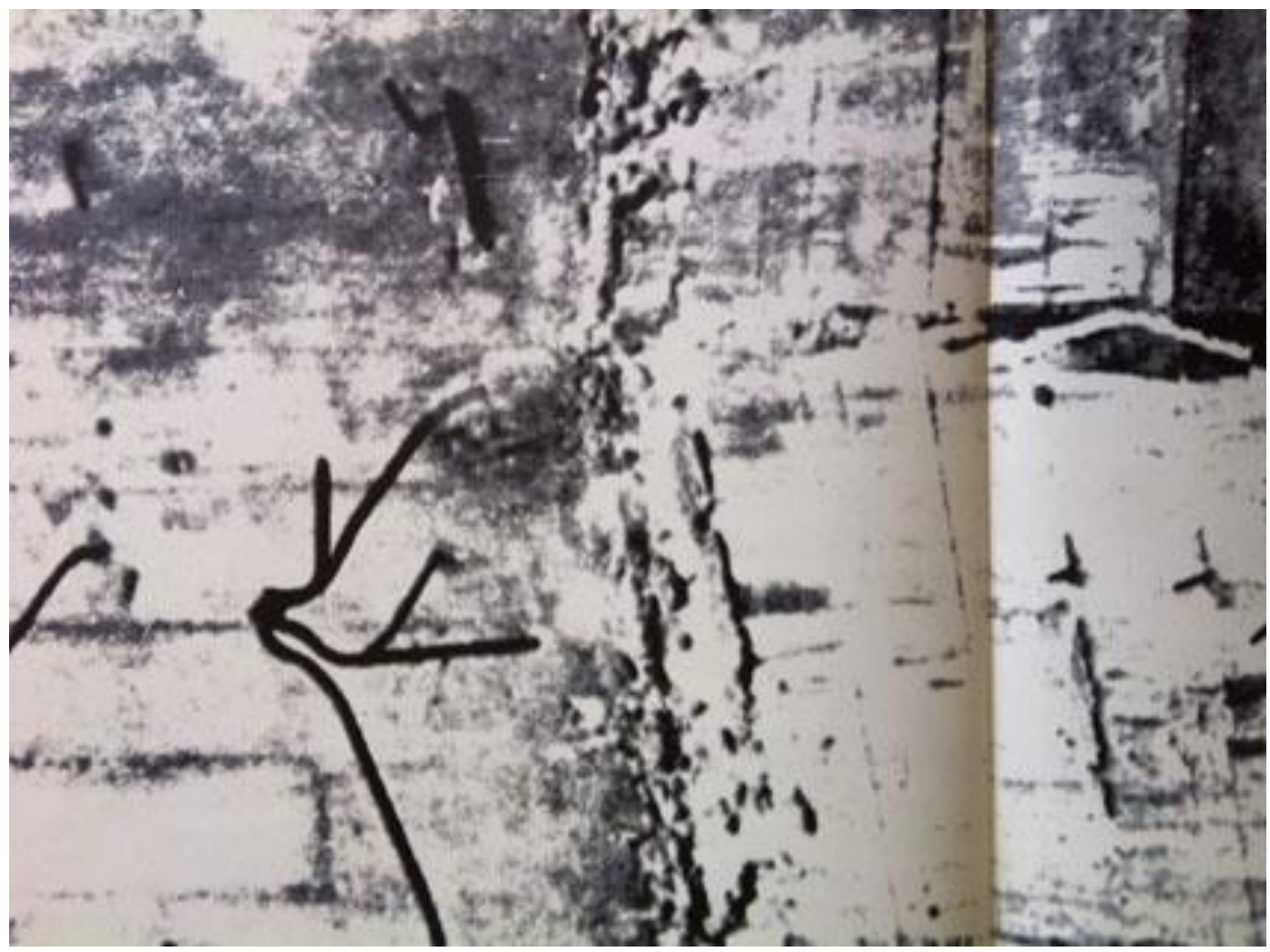

Ilustr. (103) Página do livro Doorway to Brasilia, 1959.

Fonte: Aloisio Magalhães e Eugene Feldman

\footnotetext{
${ }^{32} \mathrm{Na}$ década de 60, junto com o sistema de fotocomposição em tipografia, foi introduzido também um sistema de ampliação de cromos para gravação de chapas offset, que se chamava câmara de quarto escuro vertical ou câmara para fotorreprodução gráfica. Esse sistema consistia em uma máquina formada por uma câmara com uma lente, onde era posicionado o cromo. Através da luz esse cromo era ampliado e projetado no lado oposto à lente com a presença de uma chapa em posição vertical, pré-sensibilizada. Nesse conjunto era possível se estabelecer o tamanho da ampliação, bem como o posicionamento da imagem (corte do frame). Com isso, Eugene Feldman e Aloisio Magalhães ampliavam as imagens fotográficas bem como os detalhes a serem utilizados. Em ambos os livros que produziram também foram ampliadas as fotocomposições tipográficas. Para maiores detalhes, consultar BURDEN, La fotorreproducción em lãs artes gráficas, 1978.
} 


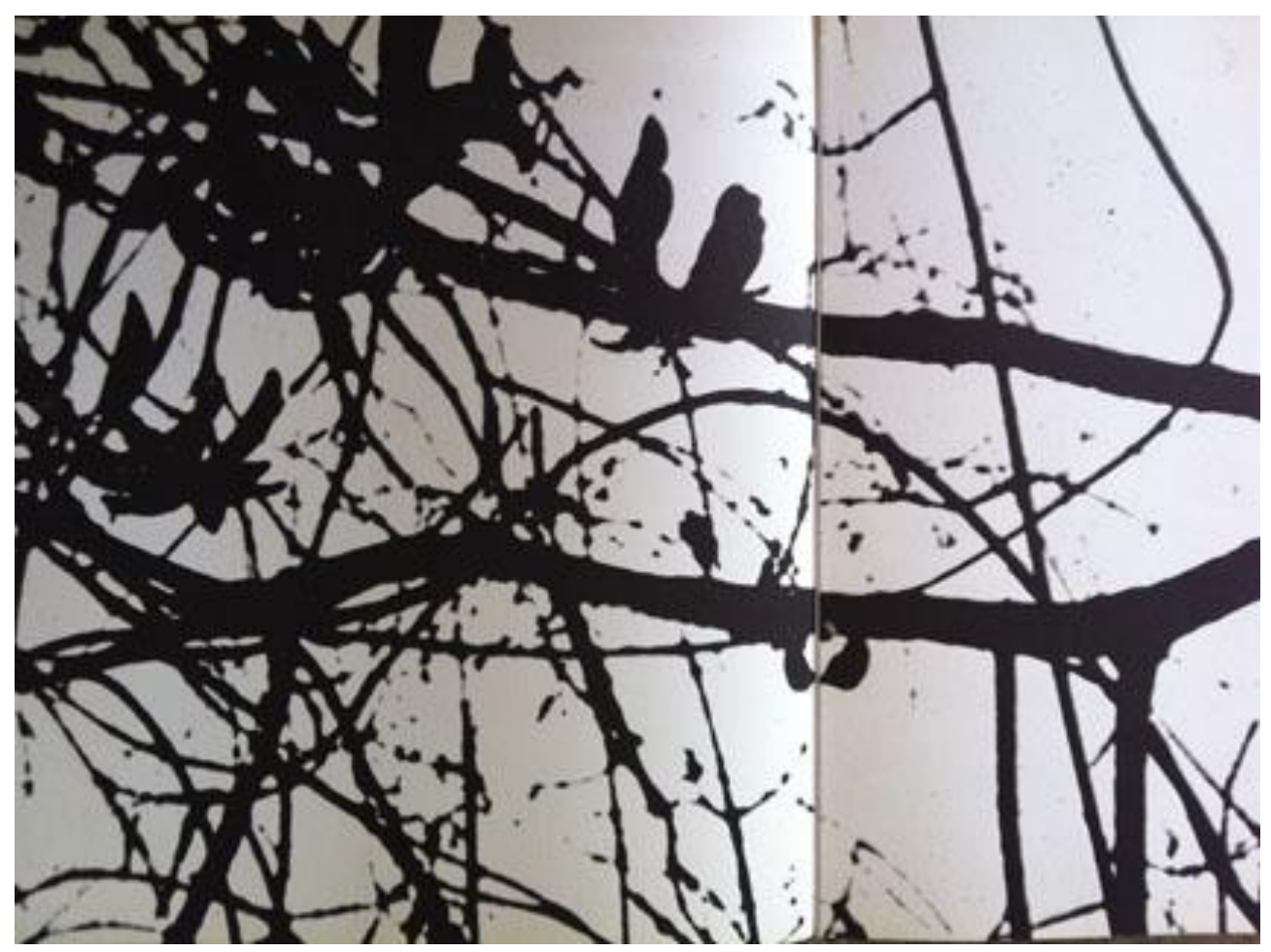

llustr. (104) Página do livro Doorway to Brasilia, 1959.

Fonte: Aloisio Magalhães e Eugene Feldman

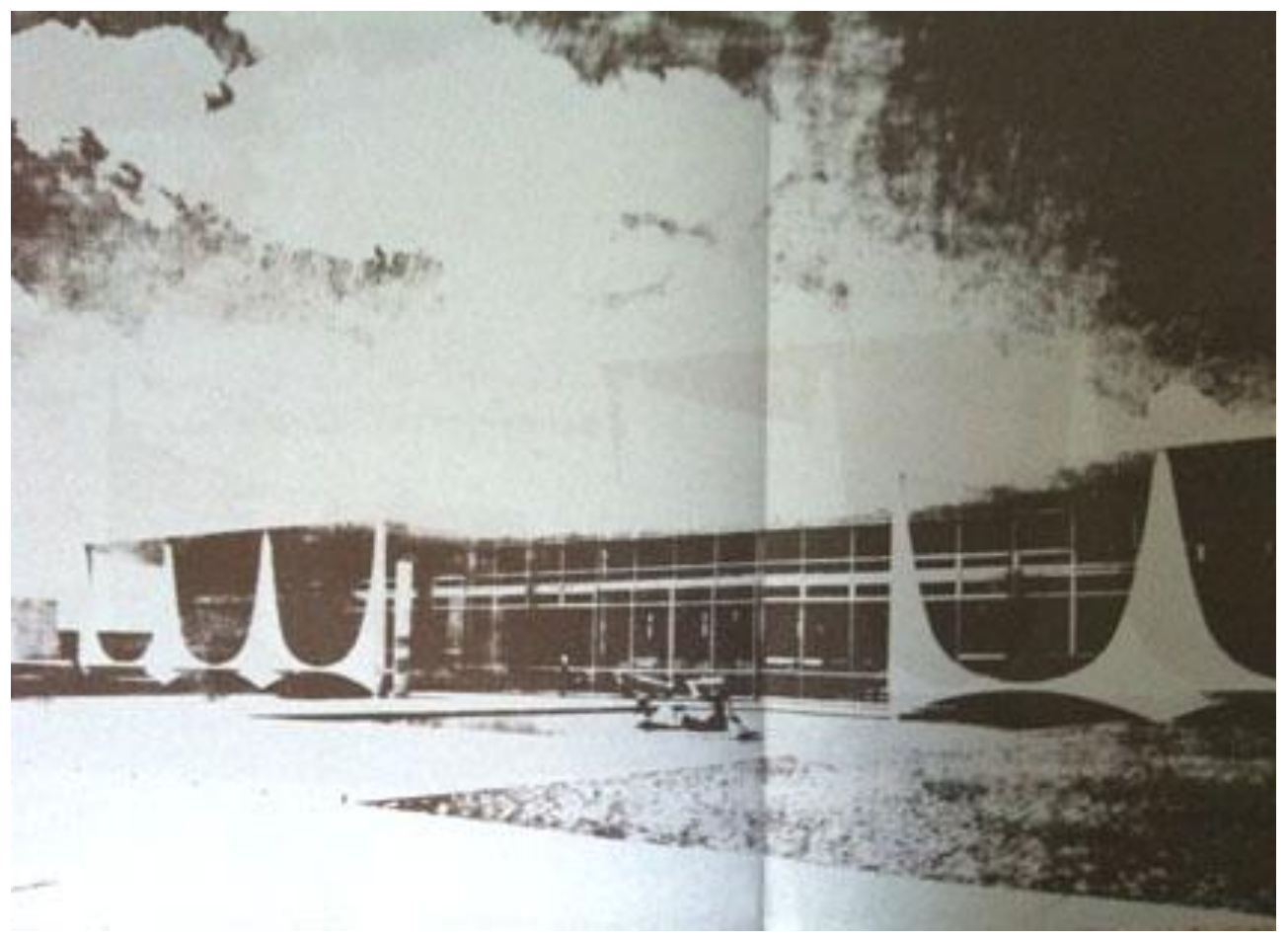

llustr. (105) Página do livro Doorway to Brasilia, 1959.

Fonte: Aloisio Magalhães e Eugene Feldman 

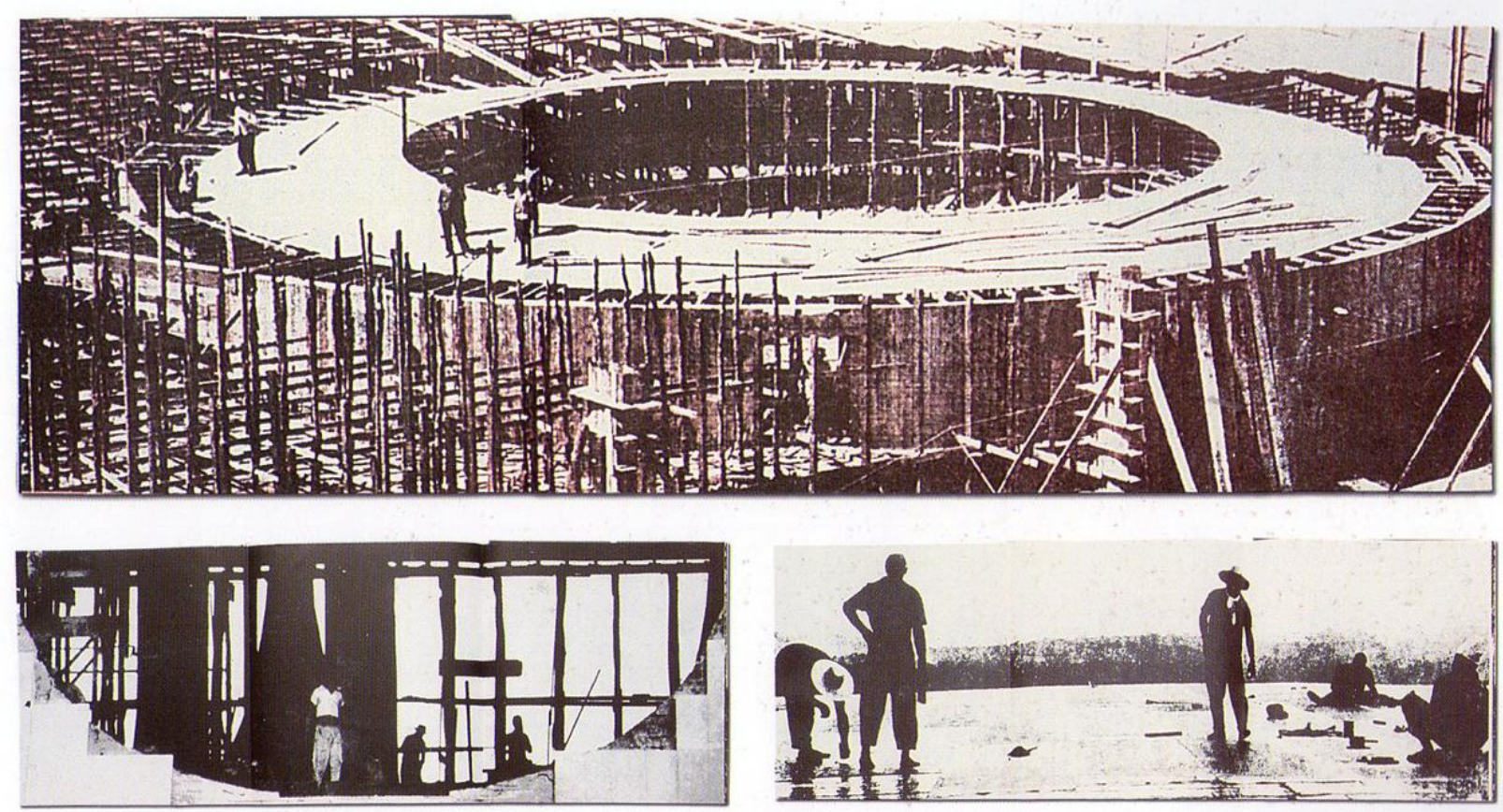

Ilustr. (106) Páginas do livro Doorway to Brasilia, 1959.

Fonte: LEITE, 2003, p. 111.

Ainda em relação às interferências na gravação das chapas para a impressão, relacionamos alguns procedimentos técnico-artísticos observados em nossa análise. O primeiro sobre o qual discorreremos, refere-se ao uso de recortes de papel para a realização de máscaras com o intuito de criarem formas.

Esse artifício, como descrito no capítulo terceiro desta tese, era usualmente praticado por Aloisio Magalhães nas ilustrações d'O Gráfico Amador, apenas com a diferença na transferência da imagem. Ou seja, em Recife, Aloisio recortava máscaras com formas "vazadas" (pochoir) e na produção com Feldman recortava pedaços de papel que eram colocados por cima da chapa ou dos filmes para a criação das formas. 
Isto se exemplifica nas páginas "G" - ilustração (93) - e "R" do livro Doorway to Portuguese, e na página com a imagem do Palácio do Planalto em Brasília no livro Doorway to Brasília abaixo relacionados:

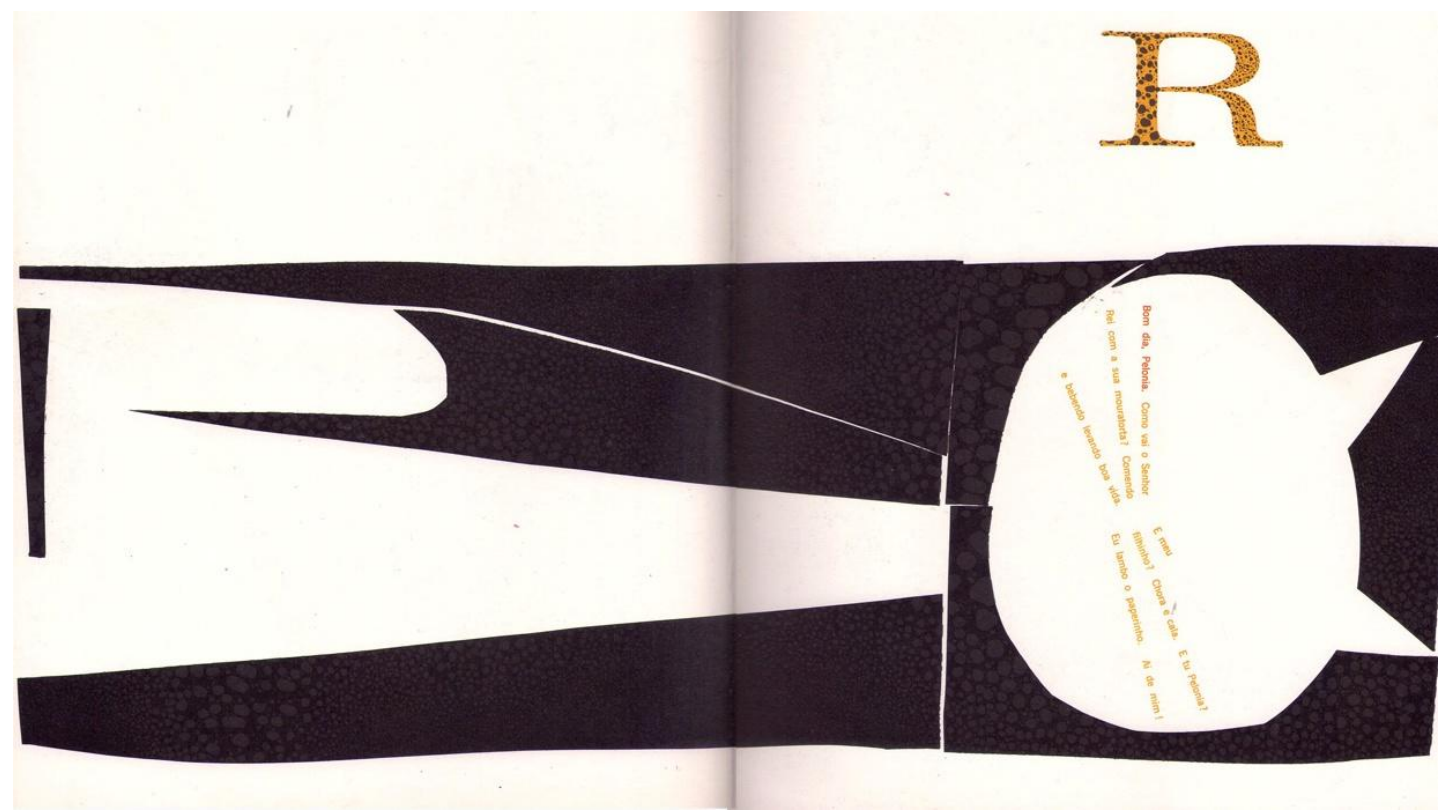

Ilustr. (107) Página R do livro Doorway to Portuguese, 1957.

Fonte: Eugene Feldman e Aloisio Magalhães
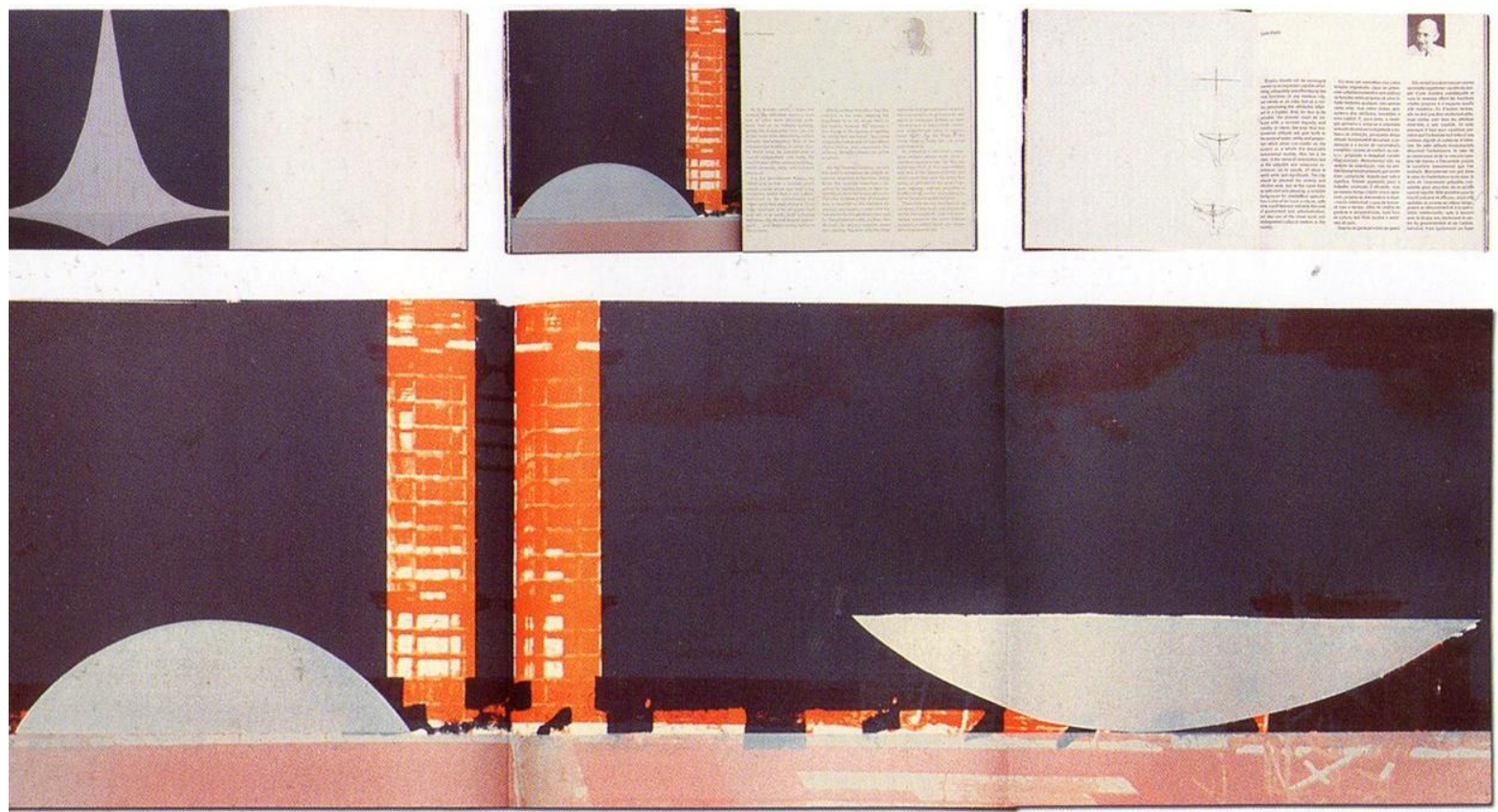

llustr. (108) Página do livro Doorway to Brasilia, 1959.

Fonte: Eugene Feldman e Aloisio Magalhães 
A sobrecapa do livro Doorway to Portuguese tem um particularidade quanto à sua criação. Aloisio Magalhães e Eugene Feldman utilizaram uma folha de palmeira diretamente colocada à chapa de impressão e deste modo realizaram a gravação da imagem na mesa de luz. Tal procedimento assemelha-se ao uso das máscaras descrito anteriormente, mas o efeito alcançado é um pouco diferente, pois ao gravar a textura da folha há uma variação maior na graduação de tonalidade (pela presença do amarelo no tom da folha) o que diferencia-se no uso de máscaras com tons contínuos e que formam superfícies chapadas.

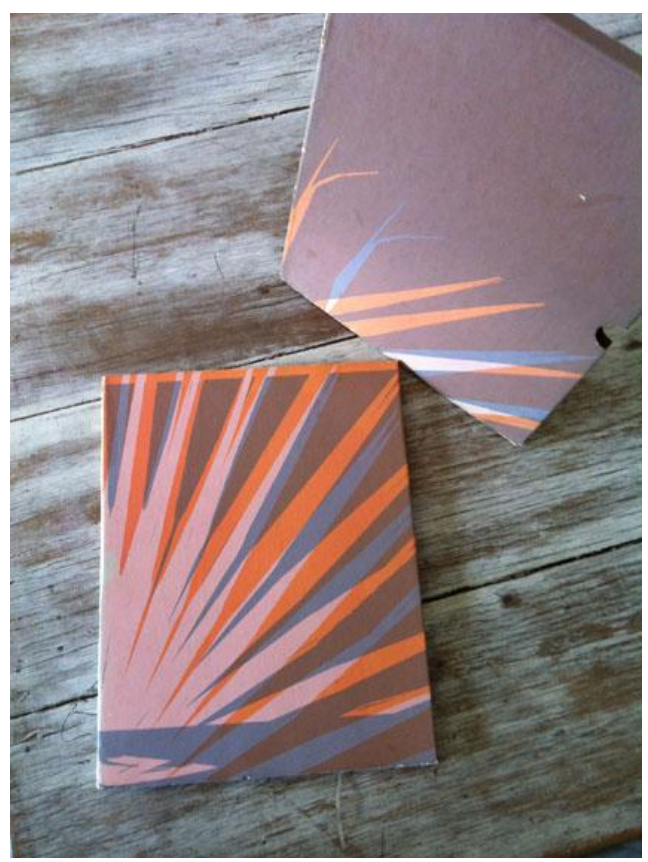

Ilustr. (109) Doorway to Portuguese, 1957.

Detalhe da capa e sobrecapa

Fonte: Eugene Feldman e Aloisio Magalhães

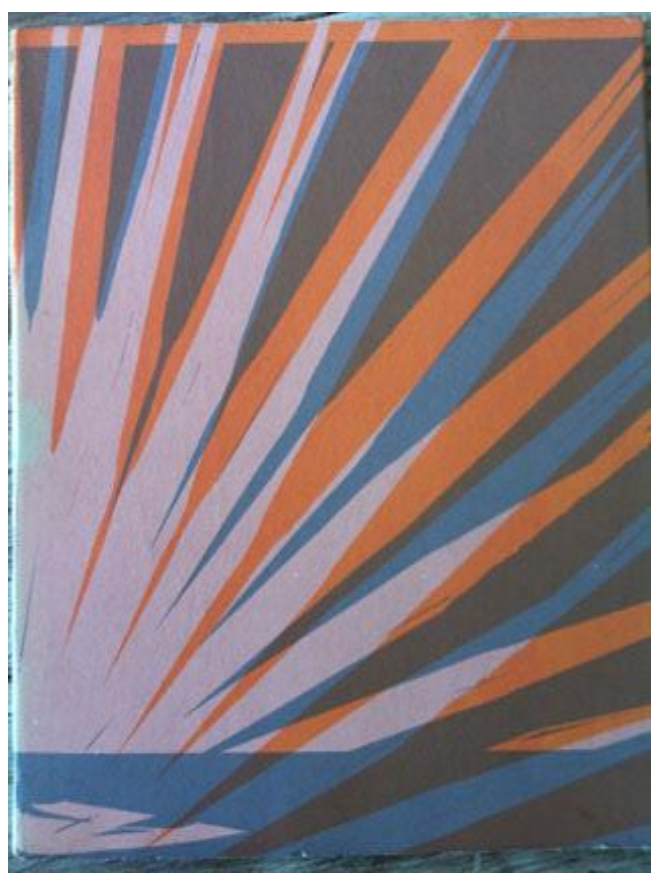

Ilustr. (110) Doorway to Portuguese, 1957.

Detalhe da capa

Fonte: Eugene Feldman e Aloisio Magalhães

Essa experiência foi repetida no setor de pré-impressão da Escola Senai Theobaldo De Nigris - Tecnologia Gráfica a fim de verificarmos tais procedimentos. A seguir, apresentam-se as etapas da análise realizada. 


\section{Teste com uma figura gravada diretamente na chapa de impressão offset:}

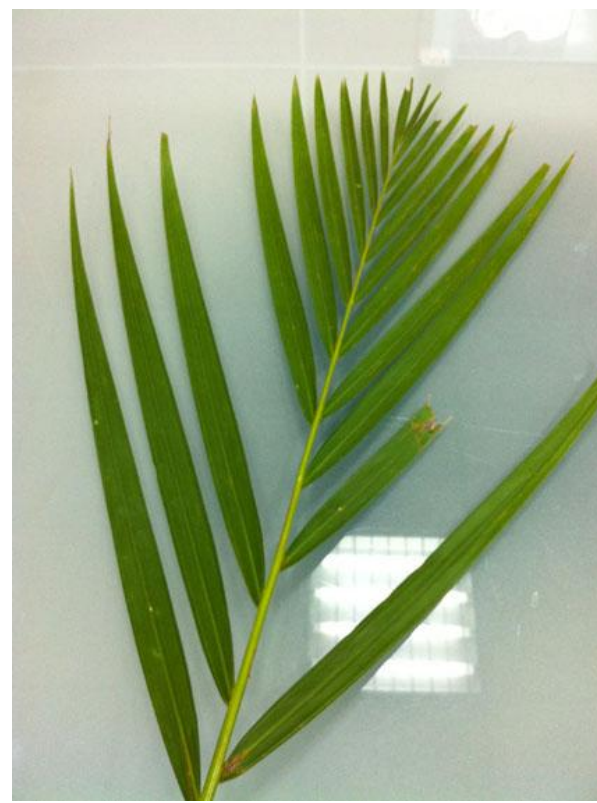

Ilustr. (111) Folha de palmeira utilizada no experimento.

Fonte: Marcos Corrêa de Mello Felisette

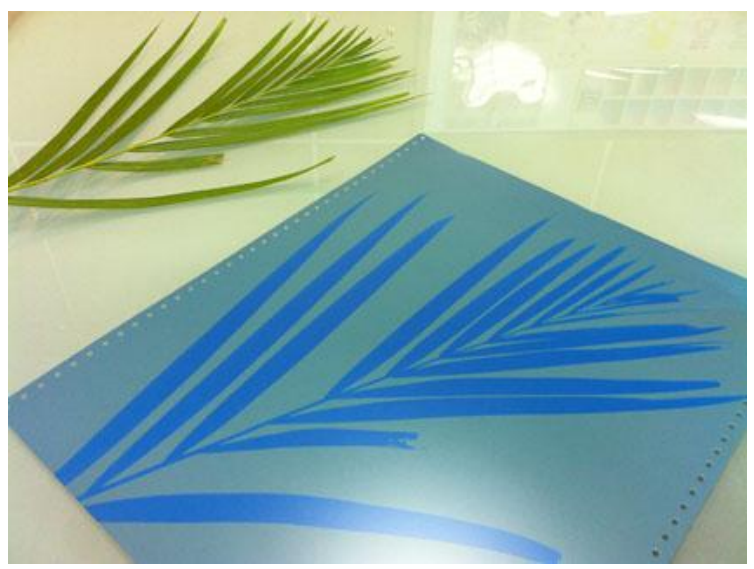

Ilustr. (112) Folha gravada diretamente na chapa de offset, apenas com a exposição da luz do sol.

Fonte: Marcos Corrêa de Mello Felisette

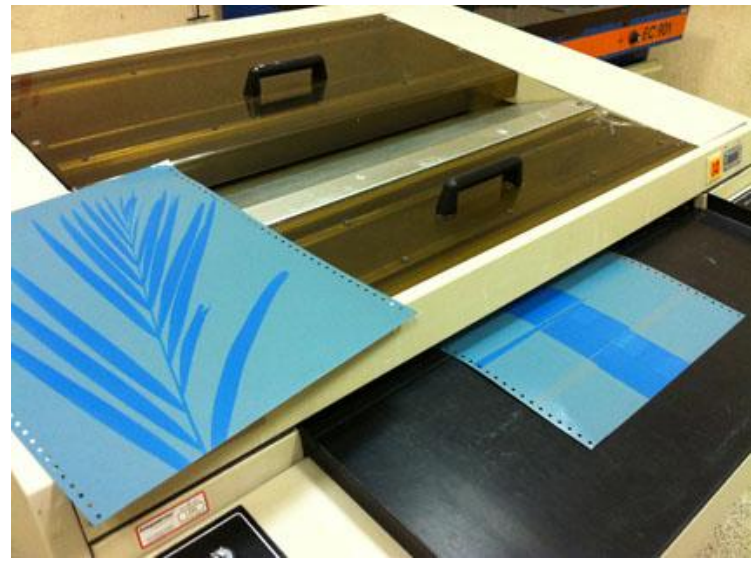

Ilustr. (113) Detalhe da máquina processadora para revelação de chapa offset.

Fonte: Marcos Corrêa de Mello Felisette

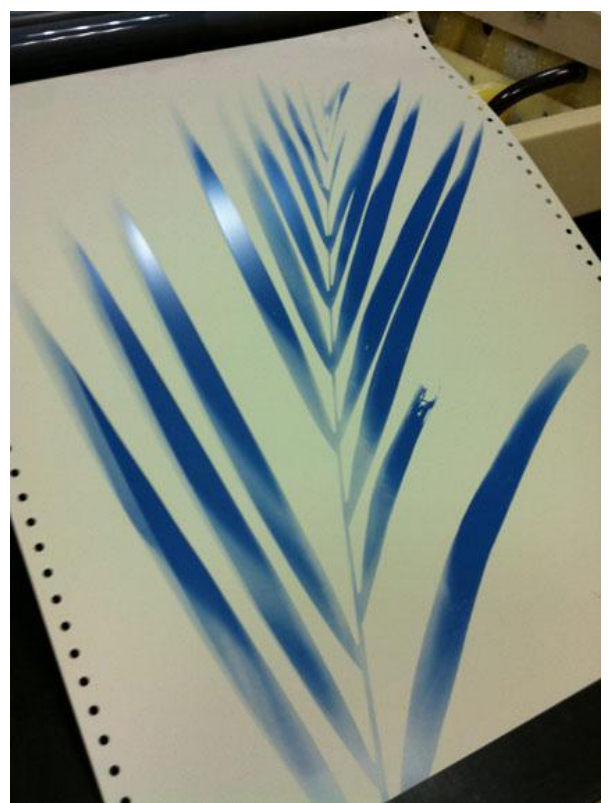

llustr. (114) Chapa revelada e pronta para impressão

Fonte: Marcos Corrêa de Mello Felisette 
Teste de gravação de chapa com tempos diferentes de exposição do mesmo cromo:

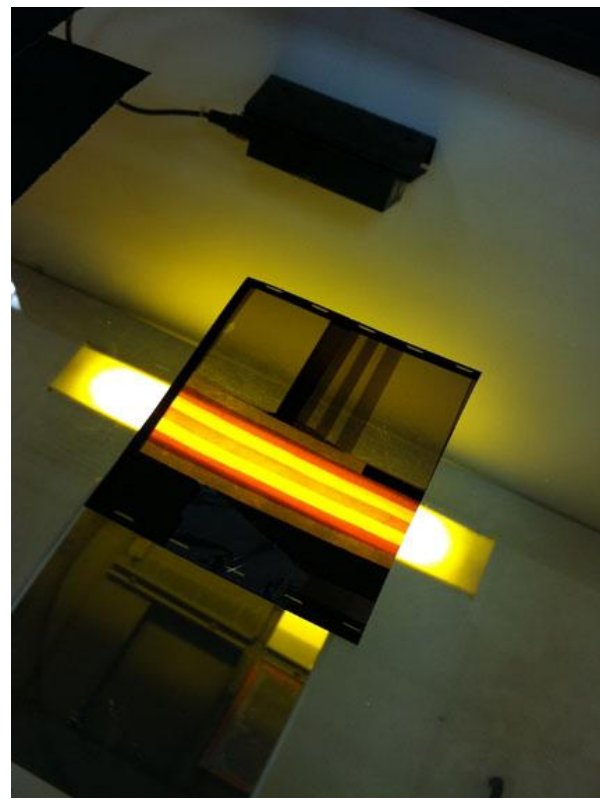

Ilustr. (115) Exemplo de gravação de cromo na mesa de luz

Fonte: Marcos Corrêa de Mello Felisette

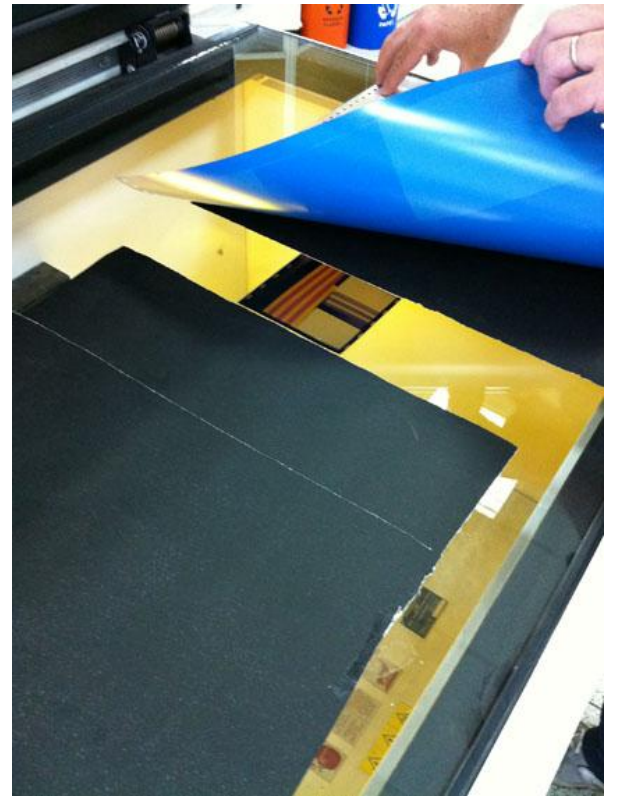

Ilustr. (117) Gravação da chapa em diferentes tempos de exposição

Fonte: Marcos Corrêa de Mello Felisette

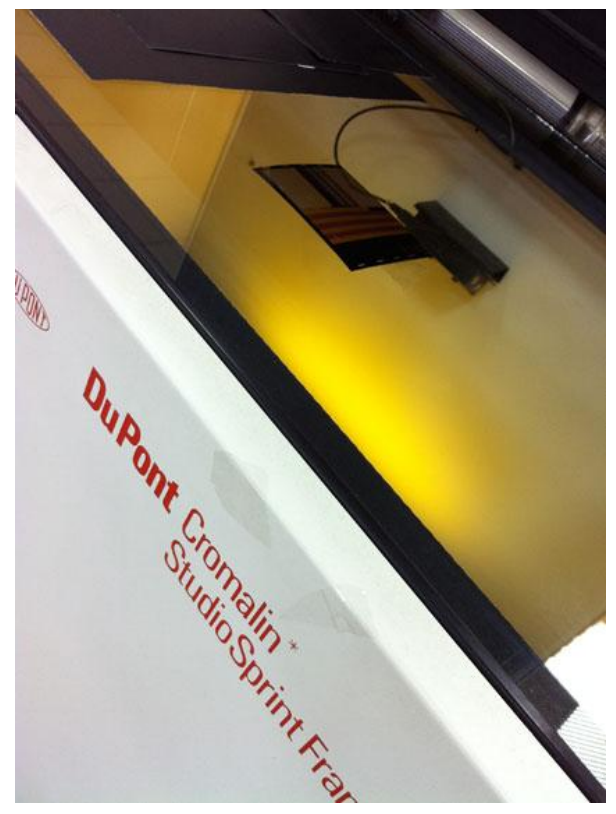

Ilustr. (116) Detalhe da mesa de luz

Fonte: Marcos Corrêa de Mello Felisette

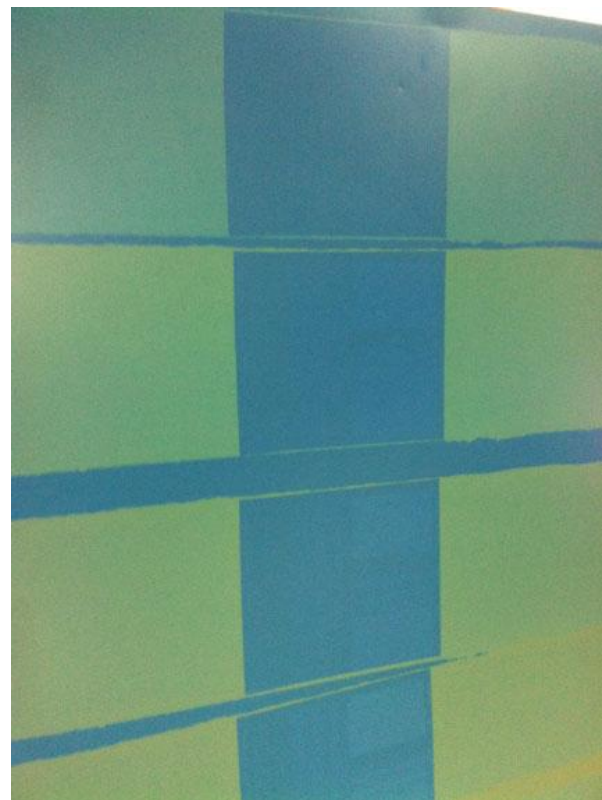

llustr. (118) Resultado da variação de exposição na gravação da chapa, utilizando o mesmo cromo Fonte: Marcos Corrêa de Mello Felisette 


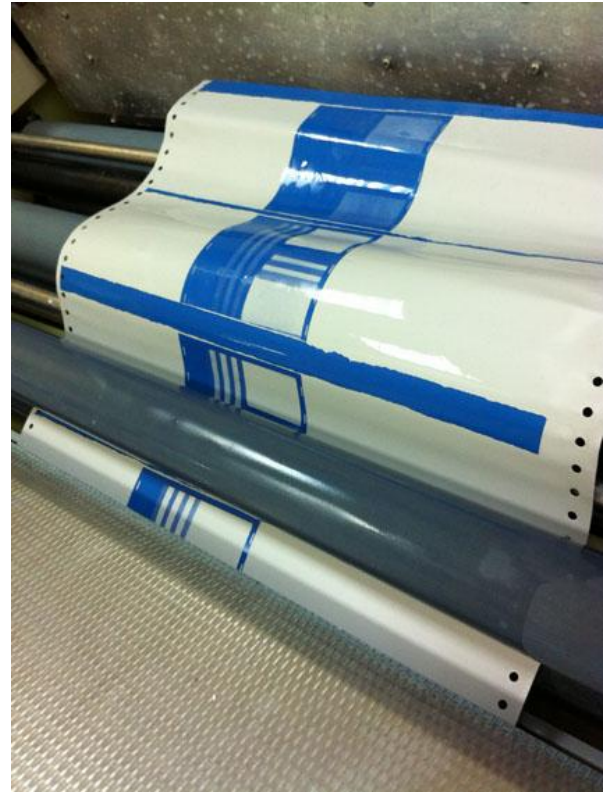

Ilustr. (119) Revelação da chapa na máquina processadora

Fonte: Marcos Corrêa de Mello Felisette

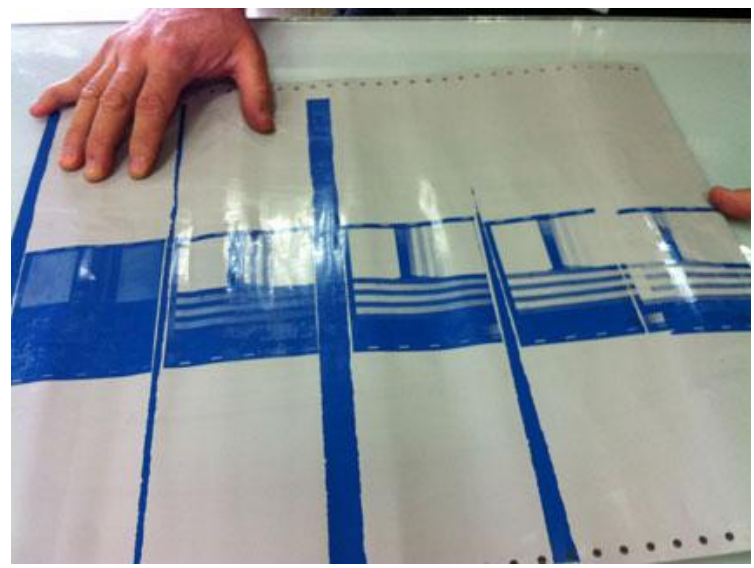

Ilustr. (120) Chapa revelada

Fonte: Marcos Corrêa de Mello Felisette

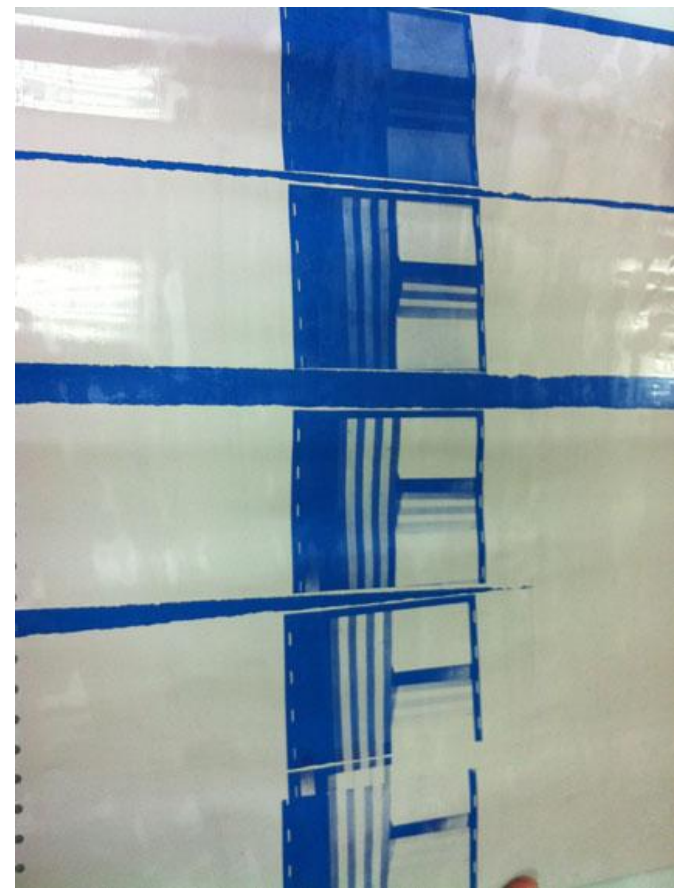

llustr. (121) Resultado da variação do tempo de exposição com o mesmo cromo Fonte: Marcos Corrêa de Mello Felisette 
Ainda decorrendo da análise na pré-impressão, observamos outra característica importante que são os desenhos realizados diretamente na chapa de impressão ou na superfície transparente do vidro com o corretor de fotolito, uma solução química aquosa utilizado à época para corrigir pequenas falhas no filme com pincel.

Aloisio Magalhães já havia trabalhado desta maneira em 1955 nos livros d'O Gráfico Amador como, Pregão Turístico do Recife e Memórias do Boi Serapião, assim, na experiência com Feldman, ele amplia e funde esta qualidade de desenho (com tinta) às técnicas desenvolvidas por Feldman. O resultado transita pela estética de imagem compreendida na expressividade, algo que Aloisio mantém em seu trabalho. Abaixo relacionamos exemplos acerca da técnica analisada:

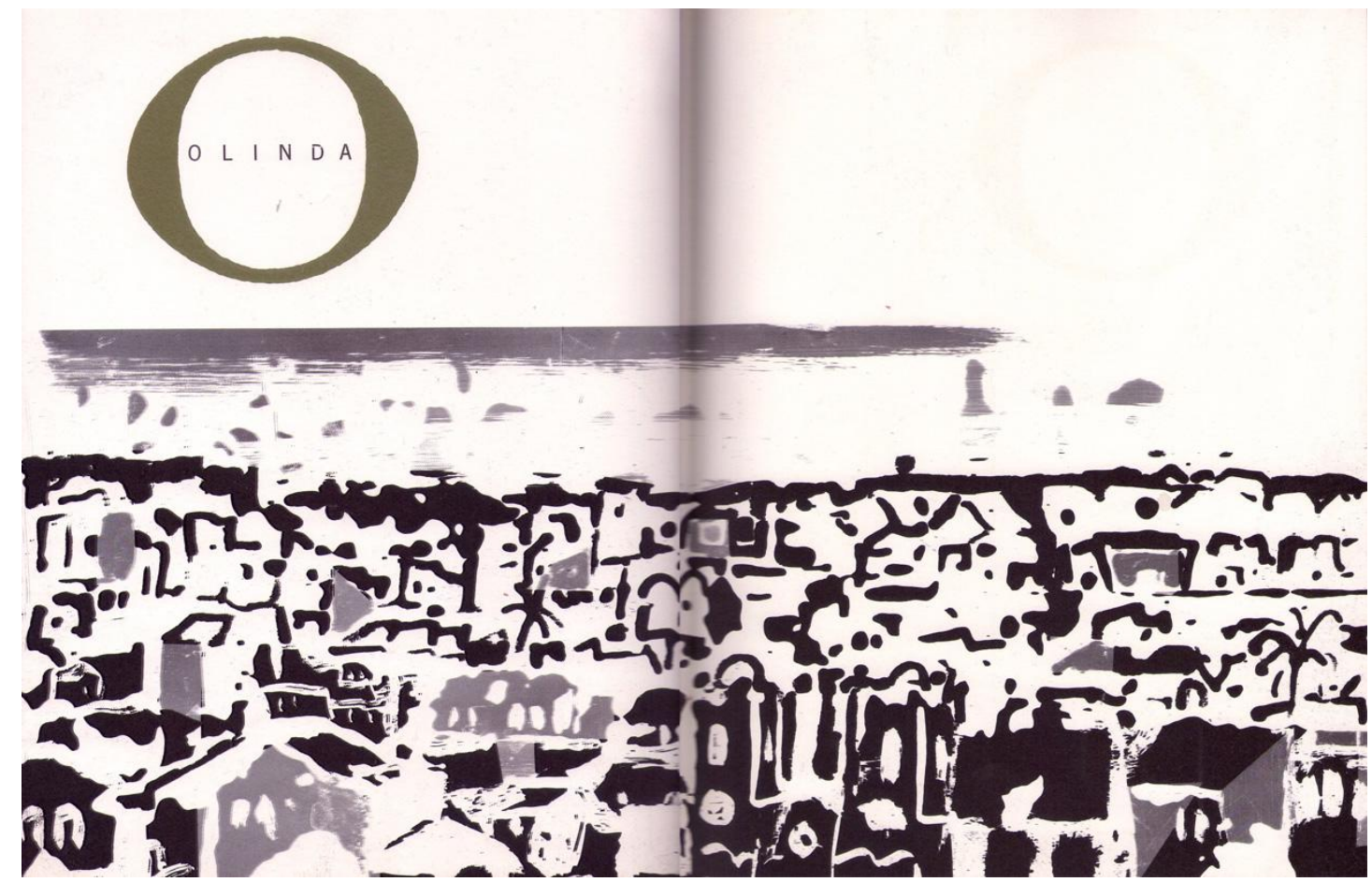

Ilustr. (122) Página O do livro Doorway to Portuguese, 1957

Fonte: Eugene Feldman e Aloisio Magalhães 


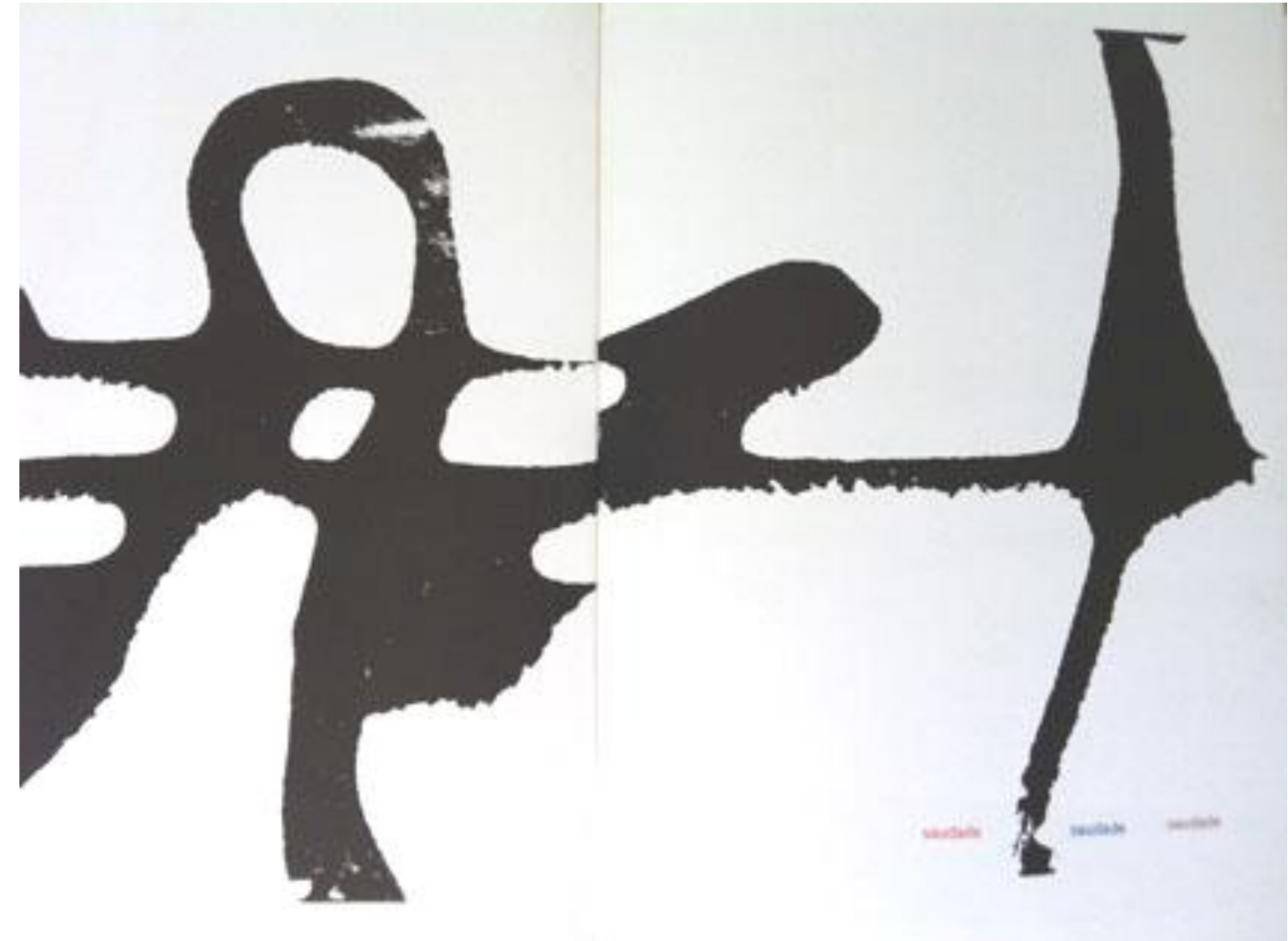

llustr. (123) Página S do livro Doorway to Portuguese, 1957

Fonte: Eugene Feldman e Aloisio Magalhães 


\section{CONCLUSÃO}

O trajeto de vida pela qual Aloisio Magalhães trilhou, nos evidencia sua predileção pela comunicação visual em um primeiro plano. Sua atitude artística era multifacetada, pluralista. Mas antes de qualquer outra consideração em relação a sua personalidade, devemos apontar que Aloisio Magalhães era uma pessoa observadora no sentido estrito do termo. Desse modo, interagia com a cultura brasileira e suas formulações no campo artístico eram respostas diretas a esta mesma cultura, em processo contínuo e ininterrupto.

Nas palavras de Leite (2003, p. 21): "[...] a ele interessava a participação, como ator e observador crítico, nos e dos seus traços mais característicos [...] pensador assistemático, mas assíduo observador, do Brasil, Aloisio Magalhães usufruiu de um lugar especial onde ele mesmo se colocou para observar e agir sobre o nosso país [...]".

Desta sua qualidade observadora, veio naturalmente a predileção pelo projeto, formulado nas bases de interação e comunicação com a sociedade. Pela sua origem, tinha estreito laço com a cultura regional mas ao mesmo tempo era amplamente conectado ao mundo, e isto se deu não só pela sua formação, mas principalmente, por estar engajado a um pensamento maior e global. Para Aloisio, o “[...] universal não é igual; universal é o diversificado, é a interligação, é a interface de diversas coisas, da heterogeneidade que compõe o caráter de uma nação." (MAGALHÃES, 1997, P. 90).

Esta simultaneidade em seu pensamento, ou seja, ao mesmo passo que pensava nas particularidades de nossa cultura relacionava-a ao âmbito global, fazendo com que se estabelecessem os valores mais puros, autênticos e 
representativos do Brasil. Assim era a sua observação diante daquilo que pensava e fazia, numa lógica estabelecida naturalmente em seu processo de criação e comunicação.

$\mathrm{Na}$ instância da ação, que marcou sua atitude em tudo que se dispôs a realizar, foi artesão, e talvez esta seja a principal lição que Aloisio nos deixou na realização do projeto gráfico e na construção de linguagem.

No aprofundamento desta questão, vimos modelos da produção gráfico editorial em nosso país e das mudanças ocorridas não somente pelo aparato tecnológico de nossas gráficas, mas principalmente nos papéis daqueles que interagem com o meio. Daí a questão entre o editor, o tipógrafo e o artista gráfico que muitas vezes fundiram-se em uma só pessoa dentro da história do livro impresso.

Ainda na qualidade de comunicador, vimos também que Aloisio Magalhães transitou pelos campos da pintura, da gravura, do desenho, do projeto editorial e do design, mas em todas estas etapas de sua vida, foi comunicador visual e esta foi sua linha de condução profissional. Acima de qualquer outra qualidade em sua linguagem, estava presente o gráfico e tinha facilidade em expressar-se por esta via.

Não à toa, encaminhou-se naturalmente para o design gráfico e requereu de suas habilidades criativas a síntese, característica que lhe era natural e the deu impulso na criação de marcas que perduram até hoje em nosso país.

Desta facilidade pela síntese, discutimos também a característica expressiva de Aloisio Magalhães e de como essa se ligava à sua linguagem gráfica. Percebe-se que o artista, mesmo ao transitar por campos diferenciados da arte ou do projeto editorial, se mantém na mesma linha expressiva, o que o distancia das correntes concretistas da década de 1950. 
A partir de 1960, quando mora e trabalha no Rio de Janeiro desenvolvendo projetos na área de design, é influenciado pelos grupos concreto e neoconcreto e alinha-se aos mesmos no percurso de formação do que viríamos a conhecer como design gráfico moderno brasileiro.

Podemos completar ainda que esse conceito de design não foi somente entendido por Aloisio Magalhães em sua passagem pelos Estados Unidos em 1956 e 1959, quando trabalhou com Eugene Feldman e conheceu de perto o Estilo Internacional. Vimos que, na época, ele se manteve no experimentalismo gráfico intensificando ainda mais sua investigação na área.

Percebe-se que para Aloisio, o contato com Eugene Feldman além de the render frutos em sua linguagem gráfica, Ihe concedeu um novo enfrentamento em relação à sua atitude projetual. Isto é, diante das novas tecnologias de impressão, muda o seu modo de interação com a máquina fazendo-o repensar a maneira com que formularia e encaminharia seus projetos à sociedade. Nesse curso, Aloisio direciona-se ainda mais ao sentido coletivo do projeto, que a partir de então, chamase design.

Não podemos deixar de expor que nesse caminho Aloisio se guardou de referências provindas não somente de sua vivência nos Estados Unidos, como também pela sua mudança para o Rio de Janeiro, onde teve contato, como já apontamos, com a ideia concretista.

Enquanto comunicador visual que era, facilmente adentrou no campo do design, afinando sua expressão gráfica à demanda da atividade. $E$ isto não quer dizer que renegou suas qualidades expressivas outrora tão presentes em sua linguagem. Trouxe para o design o requinte que tinha com as formas, a visão privilegiada do artista que possuía concisão no discurso gráfico. Estava a cursar uma 
nova etapa em sua vida, no processo natural e contínuo em que se desenvolvia a sua linguagem gráfica.

Os projetos que desenvolveu nessa época perduram ainda vivos em nossa memória e indicam todo aprofundamento e identificação de Aloisio Magalhães com a cultura brasileira. Conclui-se que esta é a grande contribuição que ele, no plano do design, trouxe como elemento de fundamento do projeto pensado a partir de nossa cultura e emergente desta.

Em contínuo movimento, sua trajetória o levou naturalmente, já em uma fase adiantada de sua carreira, à vida política, onde, com grande respeito e dedicação, preocupou-se com questões relacionadas à identidade da cultura de nosso país. 


\section{BIBLIOGRAFIA}

ALVES, Francisco. Manual do Typographo. Rio de Janeiro: Francisco Alves \& C., s/d.

AMARAL, Aracy. Artes Plásticas na Semana de 1922. São Paulo: Ed 34, 1998.

ANASTASSAKIS, Zoy. Dentro e fora da política de preservação do patrimônio cultural no Brasil: Aloisio Magalhães e o Centro Nacional de Referência Cultural. 2007. Dissertação (Mestrado em Antropologia Social)-Universidade Federal do Rio de Janeiro, Rio de Janeiro, 2007.

APOLLINAIRE, Guillaume. Caligramas. São Paulo: Ateliê Editorial, 2008.

ARAUJO, Emanuel. A construção do livro. São Paulo: Ed. Nova Fronteira, 1986.

ARGAN, Giulio Carlo. Arte Moderna. São Paulo: Ed. Companhia das Letras, 1992.

. Projeto e Destino. São Paulo: Editora Ática, 2001.

ARNS, Paulo Evaristo. A técnica do livro segundo São Jerônimo. São Paulo: Cosac Naify, 2007.

ÁVILA, Afonso. O Modernismo. São Paulo: Perspectiva, 2007.

BAIRON, Sergio. Interdisciplinaridade. São Paulo: Futura, 2002, pp. 121 - 122.

BAKHTIN, Mikhail. A Cultura Popular na ldade Média e no Renascimento - 0 Contexto de François Rabelais. São Paulo: Hucitec, 1999.

- Problemas da Poética de Dostoiévski. Rio de Janeiro: Forense Universitária, 2005.

BEIGUELMAN, Giselle. O Livro depois do Livro. São Paulo: Peirópolis, 2003. 
BENEVITES, Maria Victoria de Mesquita. O governo Kubitschec: desenvolvimento econômico e estabilidade política. Rio de Janeiro: Paz e Terra, 1979.

BENJAMIN, Walter. Obras Escolhidas III. Charles Baudelaire, um lírico no auge do capitalismo. São Paulo: Brasiliense, 1989.

. Obras Escolhidas n.1 - Magia e Técnica. São Paulo: Editora Brasiliense, 1986.

BERGER, Paulo. A Tipografia no Rio de Janeiro. Rio de Janeiro: CIA Industrial de Papel Pirahy, 1984.

BIERUT, Michael; HELFAND, Jessica; HELLER, Steven; POYNOR, Rick. Textos Clássicos do Design Gráfico. São Paulo: Martins Fontes, 2010.

BLACKWELL, Lewis. La Tipografía del Siglo XX. Barcelona: Editorial Gustavo Gili, S. A, 1993.

BLOCH, Marc Leopold Benjamin. Apologia da História. Rio de Janeiro: Jorge Zahar Ed., 2001.

BORGES, Jorge Luis. Obras Completas 1. São Paulo: Editora Globo S. A., 1998.

BOURDIEU, Pierre. A produção da Crença: contribuição para uma economia dos bens simbólicos. Porto Alegre: Zouk, 2008.

BOUTIER, Jean; JULIA, Dominique. Passados Recompostos - campos e canteiros da História. Rio de Janeiro: Editora UFRJ: Editora FGV, 1998.

BRAGANÇA, Aníbal. Livraria Ideal: do cordel à bibliofilia. Niterói: Edições Pasárgada: EdUFF, 1999. 
BRAGANÇA, Aníbal; ABREU, Marcia (orgs). Impresso no Brasil: Dois séculos de livros brasileiros. São Paulo: Editora Unesp, 2010.

BRAGANÇA, Aníbal; SANTOS, Maria Lizete dos. A profissão do poeta. Niteroi: Imprensa Oficial do Estado do Rio de Janeiro, 2002.

BRIGGS, Asa; BURKE, Peter. Uma História Social da Mídia - De Gutenberg à Internet. Rio de Janeiro: Jorge Zahar Ed., 2004.

BRINGHURST, Robert. Elementos do Estilo Tipográfico. São Paulo: Cosac Naify, 2005.

A Forma Sólida da Linguagem. São Paulo: Edições Rosari, 2006.

BURDEN, J.W. La Fotorreproducción en las Artes Gráficas. Barcelona: Escuela Gráfica Salesiana, 1978.

BURKE, Peter. O que é História Cultural? Rio de Janeiro: Jorge Zahar Ed., 2005, p. 105.

. Linguagem, Indivíduo e Sociedade. São Paulo: Editora da Universidade Estadual Paulista, 1993.

. Variedades de História Cultural. Rio de Janeiro: Civilização Brasileira, 2000.

CAMPOS, Augusto de; CAMPOS, Haroldo de; PIGNATARI, Décio. Teoria da Poesia Concreta. São Paulo: Ateliê Editorial, 2006.

CANCLINI, Néstor Garcia. Culturas Híbridas: Estratégias para Entrar e Sair da Modernidade. São Paulo: Editora da Universidade de São Paulo, 2000.

CARAMELLA, Elaine. História da Arte: fundamentos semióticos: teoria e método em debate. Bauru SP: EDUSC, 1998. 
CARDOSO, Rafael. O Design brasileiro antes do design: aspectos da história gráfica, 1870 - 1960. São Paulo: Cosac Naify, 2005.

. Uma Introdução à História do Design. São Paulo: Blucher, 2008.

CERTEAU, Michel de. A Escrita da História. Rio de Janeiro: Forense Universitária, 2002.

. A Invenção do Cotidiano. Rio de Janeiro: Editora Vozes, 2004.

CHARTIER, Roger. Os desafios da escrita. São Paulo: Editora UNESP, 2002.

El Mundo como representation - Estudios sobre historia cultural. Lisboa: Editorial Gedisa, 2005.

CHAPPELL, Warren; BRINGHURST, Robert. A Short History of the Printed Word. Vancouver: Hartley \& Marks Publishers Inc, 1999.

CLAUDIO, José. História do pintor Aloisio Magalhães. In: LEITE, João de Souza; TABORDA, Felipe. A Herança do Olhar: o design de Aloisio Magalhães. Rio de Janeiro: Artviva, 2003. pp. $38-45$.

CONTIER, Arnaldo Daraya. Imprensa e Ideologia em São Paulo, 1822 - 1842. Petrópolis: Editora Vozes, 1979.

. Brasil Novo. Música, Nação e Modernidade: os anos 20 e 30. 1988. Tese (Livre docência em História)-Universidade de São Paulo, São Paulo, 1988.

COSTELA, F. Antonio. Comunicação: do grito ao satélite. São Paulo: Editora Mantiqueira, 2002.

DARNTON, Robert. O beijo de Lamourette. São Paulo: Companhia das Letras, 1990. 
DARNTON, Robert; ROCHE, Daniel. A Revolução Impressa: A Imprensa na França. São Paulo: Editora da Universidade de São Paulo, 1996.

DONDIS, A. Donis. Sintaxe da Linguagem Visual. São Paulo: Martins Fontes, 1997.

EINSENSTEIN, Elisabeth. The Printing Press as an Agent of Change. Cambridge: University Press, 1997.

ELLIMAN, Paul. City of Words in Eye Magazine, 40 - Vol. 10, Summer. Londres: Quantum Publishing, 2001.

ESCOREL, Ana Luisa. O Efeito Multiplicador do Design. São Paulo: Editora Senac São Paulo, 2000.

FARIAS, Priscila. Tipografia Digital - O impacto das novas tecnologias. Rio de Janeiro: 2AB, 2001.

FARIAS, Priscila; PIQUEIRA, Gustavo. Fontes Digitais Brasileiras: de 1989 a 2001. São Paulo: Edições Rosari, 2003, pp. 107, 125.

FAUSTO, Boris. História do Brasil. São Paulo: Ed. Da Universidade de São Paulo, 2009.

FELDMAN, Eugene. Eugene Feldman, por Feldman. In: LEITE, João de Souza; TABORDA, Felipe. A Herança do Olhar: o design de Aloisio Magalhães. Rio de Janeiro: Artviva, 2003. pp. $100-101$.

FERLAUTO, Claudio. O Tipo da Gráfica e Outros Escritos. São Paulo: Editora Cachorro Louco, 2000.

. A Fôrma e a Forma. São Paulo: Edições Rosari, 2003. 
FERNANDES BRAGA, Isis. Aloisio Magalhães: as faces culturais do design no Brasil (1960 e 1970). 2004. Tese (Doutorado em Artes Visuais)-Universidade Federal do Rio de Janeiro, Rio de Janeiro, 2004.

FERRARA, Lucrécia. A Estratégia dos Signos. São Paulo: Editora Perspectiva, 1986.

FERREIRA, Jerusa Pires. Livros, Editoras e Projetos. São Paulo: Ateliê Editorial, 1997.

FERREIRA, Orlando da Costa. Imagem e Letra. São Paulo: Edusp, 1976.

FLUSSER, Vilém. O Mundo Codificado: por uma filosofia do design e da comunicação. São Paulo: Cosac Naify, 2007.

FONSECA, Maria Cecília Londres. O Patrimônio em processo: trajetória da política federal de preservação no Brasil. 2. ed. rev. amp. Rio de Janeiro: Ed. UFRJ; MinC IPHAN, 2005 (1997).

FRUTIGER, Adrian. Sinais e Símbolos. São Paulo: Martins Fontes, 1999.

GARCIA CANCLINI, Néstor. Culturas Híbridas: Estratégias para Entrar e Sair da Modernidade. São Paulo: Editora da Universidade de São Paulo, 2000.

GAUDÊNCIO JÚNIOR, Norberto. A herança escultórica da tipografia. São Paulo: Edições Rosari, 2004.

GEERTZ, Clifford. A Interpretação das Culturas. Rio de Janeiro: LTC, 1989, pp. 4, 7.

GENETTE, Gérard. Paratextos Editoriais. São Paulo: Ateliê Editorial, 2009.

GINZBURG, Carlo. O queijo e os Vermes. São Paulo: Companhia das Letras, 1987.

GOMBRICH, E. H.; História da Arte. São Paulo: LTC Editora, 2002. 
GROUPIUS, Walter. Bauhaus - novarquitetura. São Paulo: Ed. Perspectiva.

GRUSZYNSKI, Ana Claudia. Design Gráfico: Do Invisível ao llegível. Rio de Janeiro: 2AB Editora, 2002.

HALEY, Allan. Typographic Milestones. Nova York: Van Nostrand Reinhold, 1992.

HALLEWELL, Laurence. O Livro no Brasil: sua história. São Paulo: Editora da Universidade de São Paulo, 2005.

HASLAM, Andrew. O Livro e o Designer II. São Paulo: Edições Rosari, 2007.

HEITLINGLER, Paulo. Tipografia: origens, formas e uso das letras. Lisboa: Dinalivro, 2006.

HELLER, Steven; FILI, Lousie. Typology: Type Design from Victorian Era to the Digital Age. California: Chronicle Books, 1999.

HELLER, Steven. Linguagens do Design: compreendendo o design gráfico. São Paulo: Edições Rosari, 2007.

HENDEL, Richard. O Design do Livro. São Paulo: Ateliê Editorial, 2006.

HOBSBAWN, Eric J.; A Era dos Extremos: o breve século XX (1914 - 1991). São Paulo: Companhia das Letras, 1996.

HOLLIS, Richard. Design Gráfico, uma história Concisa. São Paulo: Martins Fontes, 2000.

HOLANDA, Sérgio Buarque de. Raízes do Brasil. São Paulo: Companhia das Letras, 1995. 
HORCADES M. Carlos. A Evolução da Escrita. Rio de Janeiro: Editora Senac Rio, 2004.

HURLBURT, Allen. Layout: o design da página impressa. São Paulo: Nobel, 1999.

IPANEMA, Cybelle de. A Tipografia em São Paulo: uma contribuição à história de suas origens. São Paulo: COM-ARTE, 2008.

IVINS, William. Prints and Visual Communication. Cambridge: The MIT Press, 1973.

JATAHY PESAVENTO, Sandra. Escrita, Linguagem, Objetos - Leituras de História Cultural. Bauru - SP: EDUSC, 2004.

JÚNIOR, Caio Prado. Formação do Brasil Contemporâneo. São Paulo: Brasiliense, 2004.

LAURENIO DE MELO. Aloisio e o TEP. In: LEITE, João de Souza; TABORDA, Felipe. A Herança do Olhar: o design de Aloisio Magalhães. Rio de Janeiro: Artviva, 2003. pp. $28-33$.

LE GOFF, Jacques. História e Memória. Campinas, S.P: Editora da Unicamp, 2003.

LEITE, João de Souza; TABORDA, Felipe. A Herança do Olhar: o design de Aloisio Magalhães. Rio de Janeiro: Artviva, 2003.

LEITE, João de Souza; Aloisio Magalhães, aventura paradoxal no design brasileiro. Ou, o design como instrumento civilizador? 2006. Tese (Doutorado em Ciências Sociais - PPCIS) - Universidade do Estado do Rio de Janeiro, 2006.

LEMERRE, Alphonse. Le Livre du Bibliophile. Paris: Alphonse Lemerre, Libraire, 1874.

LIMA, Guilherme Cunha. O Gráfico Amador: as origens da moderna tipografia brasileira. Rio de Janeiro: Editora URFJ, 1997. 
. O lúdico e o informal. In: Revista ADG. São Paulo: ADG, n.19, mar. 2000, p. $22-24$.

. O Gráfico Amador, os anos de formação no Recife. In: LEITE, João de Souza; TABORDA, Felipe. A Herança do Olhar: o design de Aloisio Magalhães. Rio de Janeiro: Artviva, 2003. pp. 84 - 93.

LUCIO, Agra. História da Arte do século XX: ideias e movimentos. São Paulo: Ed. Anhembi Morumbi, 2004.

LUPTON, Ellen. Pensar com tipos: guia para designers, escritores, editores e estudantes. São Paulo: Cosac Naify, 2006.

LUPTON, Ellen; MILLER, J. Abbott. $A B C$ da Bauhaus: a Bauhaus e a teoria do design. São Paulo: Cosac Naify, 2008.

LUPTON, Ellen; PHILLIPS, Jennifer Cole. Novos Fundamentos do Design. São Paulo: Cosac Naify, 2008.

LUQUIN, Félix. La Scuola Tipografia Moderna. Milão: Scuola Tipografica Salesiana, 1907.

MACEDO, Joaquim Manoel de. Memórias da Rua do Ouvidor. Rio de Janeiro: H. Garnier, Livreiro Editor, s/d.

MAGALHÃES, Aloisio. E Triunfo? A questão dos bens culturais no Brasil. Rio de Janeiro: Nova Fronteira; Fundação Roberto Marinho, 1997.

. Sobre o ensino das artes, no Recife, em 1958. In: LEITE, João de Souza; TABORDA, Felipe. A Herança do Olhar: o design de Aloisio Magalhães. Rio de Janeiro: Artviva, 2003. pp. $58-64$. 
. Eugene Feldman, visto por Aloisio Magalhães. In: LEITE, João de Souza; TABORDA, Felipe. A Herança do Olhar: o design de Aloisio Magalhães. Rio de Janeiro: Artviva, 2003. pp. 96 - 99.

MANDEL, Ladislas. Escritas - Espelho dos Homens e das Sociedades. São Paulo: Rosari, 2006, pp. 11, 13, 15.

MANGUEL, Alberto. Uma história da leitura. São Paulo: Companhia das Letras, 1997.

MARTINS, Ana Luiza; LUCA, Tania Regina de. História da Imprensa no Brasil. São Paulo: Contexto, 2008.

MARTINS, Fernanda. Quando uma parceria dá certo - Bembo. São Paulo: Editora Rosari, 2003.

MARTINS FILHO, Plinio. A Arte do Invisível. São Paulo: Ateliê Editorial, 2003.

MARTINS, Wilson. A Palavra Escrita. São Paulo: Editora Anhembi, 1957.

MEGGS, Philip B. História do Design Gráfico. São Paulo: Cosac Naify, 2009.

MEYER, Marlyse. Do Almanak aos Almanaques. São Paulo: Ateliê Editorial, 2001.

MELO, Chico Homem de. O Design Gráfico Brasileiro: anos 60. São Paulo: Cosac Naify, 2008.

. Os Desafios do Designer. São Paulo: Edições Rosari, 2003.

- Linha do Tempo do Design Gráfico no Brasil. São Paulo: Cosac Naify, 2011.

McLEAN, Ruari. Jan Tschichold: A life in Typography. New York: Princeton Architectural Press, 1999. 
McLUHAN, Marshall; B.R. Powers. La Aldea Global. Barcelona: Editorial Gedisa, 2002.

. Os Meios de Comunicação - como extensões do homem. São Paulo: Cultrix, 2003.

- A Galáxia de Gutenberg: a formação do homem tipográfico. São Paulo: Ed. Da Universidade de São Paulo, 1969.

MINDLIN, José. No Mundo dos Livros. Rio de Janeiro: Agir, 2009.

MORAES, Dijon De. Análise do design brasileiro: entre mimese e mestiçagem. São Paulo: Edgard Blucher, 2006.

MORAES, Rubens Borba de. O bibliófilo Aprendiz. São Paulo: Companhia Editora Nacional, 1965.

MORIN, Edgar. Ciência com Consciência. Rio de Janeiro: Editora Bertrand Brasil, 2001.

MOUTON, Éugene. L'art D'écrire un Livre De L'imprimer et de Le Publier. Paris: $\mathrm{H}$. Welter, 1896.

NETO, João Cabral de Melo. A Educação da Pedra e Depois. Rio de Janeiro: Nova Fronteira, 1997.

PANOFSKY, Erwin. Significado nas Artes Visuais. São Paulo: Editora Perspectiva, 2002.

PELLEGRINI FILHO, Américo. Folclore: a comunicação escrita e urbana. 1987. Tese (Doutorado em Comunicações e Artes)-Universidade de São Paulo, São Paulo, 1987. 
PIGNATARI, Décio. Semiótica e Literatura. São Paulo: Cortez, 1987.

PLAZA, Julio. Tradução Intersemiótica. São Paulo: Perspectiva, 2010.

PURVIS, Alston W. H. N. Werkman. Londres: Rick Poynor. 2004

REDIG, Joaquim. Fundamentos do Design de Aloisio Magalhães: Design BR 1970. 2007. Dissertação (Mestrado em Design)-Universidade do Estado do Rio de Janeiro, Rio de Janeiro, 2007.

RIBEIRO, Darcy. O Povo Brasileiro: a formação e o sentido do Brasil. São Paulo: Companhia das Letras, 2006.

RICKEY, George. Construtivismo. São Paulo: Cosac Naify, 2006.

RIZZINI, Carlos. O Livro, o Jornal e a Tipografia no Brasil - 1500-1822. Rio de Janeiro: Livraria Kosmos Editora, 1945.

. O Jornalismo antes da Tipografia. São Paulo: Companhia Editora Nacional, 1977.

ROCHA, Claudio. In: Revista Tupigrafia. São Paulo: Bookmakers, 2002. . Projeto Tipográfico: análise e produção de fontes digitais. São Paulo: Editora Rosari, 2002.

- A letra impressa parte I - produção de matrizes de tipos de metal. In: Revista Tecnologia Gráfica. São Paulo: ABTG - Associação Brasileira de Tecnologia Gráfica e da Faculdade Senai de Tecnologia Gráfica. Ano XV, n. 79, v. IV, 2011

A letra impressa parte II - matrizes mecânicas e a fundição de tipos. In: Revista Tecnologia Gráfica. São Paulo: ABTG - Associação Brasileira de Tecnologia Gráfica e da Faculdade Senai de Tecnologia Gráfica. Ano XV, n. 80, v. IV, 2011. 
A letra impressa parte III - matrizes para composição mecânica. In: Revista Tecnologia Gráfica. São Paulo: ABTG - Associação Brasileira de Tecnologia Gráfica e da Faculdade Senai de Tecnologia Gráfica. Ano XV, n. 81, v. IV, 2012.

A letra impressa parte IV - a revolução da fotocomposição. In: Revista Tecnologia Gráfica. São Paulo: ABTG - Associação Brasileira de Tecnologia Gráfica e da Faculdade Senai de Tecnologia Gráfica. Ano XV, n. 82, v. IV, 2012.

SATUÉ, Enric. Aldo Manuzio: editor, tipógrafo, livreiro. São Paulo: Ateliê Editorial, 2004.

SCHRAPPE, Max H. G. O Legado de Gutenberg. São Paulo: EP \& Associados, Parise Comunicação Empresarial, 2002.

SEMERARO, Claudia Marino; AYROSA, Christiane. História da Tipografia no Brasil. São Paulo: Museu de Arte de São Paulo, 1979.

SKIDMORE, Thomas. Brasil: De Getúlio Vargas a Castelo Branco. Rio de Janeiro: Paz e Terra, 1982.

SMEIJERS, Fred. Counter Punch: Making Type in the Sixteenth Century, Designing Typefaces Now. Londres: Hyphen Press, 1996.

SOBRAL, Julieta. O desenhista invisível. Rio de Janeiro: Edições Folha Seca, 2007.

SOUZA, Ricardo Luiz de. Identidade Nacional e Modernidade Brasileira: o diálogo entre Silvio Romero, Euclides da Cunha, Câmara Cascudo e Gilberto Freyre. Belo Horizonte: Autêntica, 2007.

STANGOS, Nikos. Conceitos da Arte Moderna. Rio de Janeiro: Jorge Zahar Editora, 2000.

STOLARSKI, André. Alexandre Wollner e a formação do design moderno no Brasil. São Paulo: Cosac Naify, 2005. 
TANG, Roger Fawcett. O Livro e o Designer I. São Paulo: Edições Rosari, 2007.

TRAVASSOS, Nelson Palma. Livro sobre livros. São Paulo: Hucitec, 1978.

TSCHICHOLD, Jan. Tipografia Elementar/ Iwan Tschichold. São Paulo: Altamira Editorial, 2007.

. A Forma do Livro: ensaios sobre tipografia e estética do livro. São Paulo: Ateliê Editorial, 2007.

WEINGART, Wolfgang. Como se pode fazer Tipografia Suíça? São Paulo: Editora Rosari, 2004.

WEYMAR, Lúcia Bergamashi Costa; NUNES, João Fernando Igansi. Tempos Gráficos, diário de época. São Paulo: Editora Rosari, 2003.

WOLLNER, Alexandre. Textos recentes e escritos históricos. São Paulo: Rosari, 2002

ZAPF, Hermann. A Arte da Tipografia. São Paulo: Edições Rosari, 2010. 